MARCOS PAULO BATISTA DE ASSUNÇÃO

Plataforma digital: método complementar de ensino-aprendizagem da embriologia comparativa

São Paulo

2020 


\section{MARCOS PAULO BATISTA DE ASSUNÇÃO}

Plataforma digital: método complementar de ensino-aprendizagem da embriologia comparativa

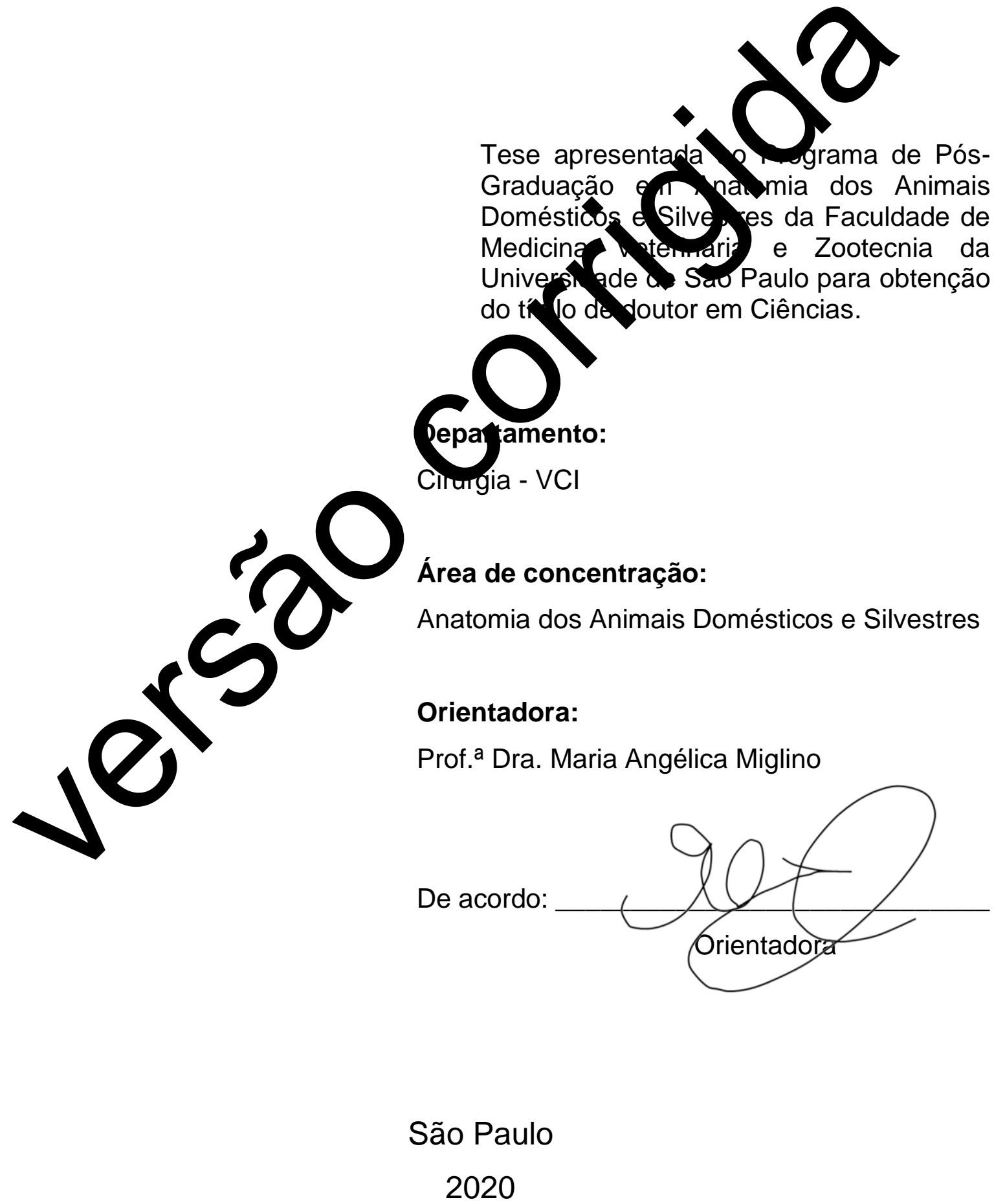


Autorizo a reprodução parcial ou total desta obra, para fins acadêmicos, desde que citada a fonte.

DADOS INTERNACIONAIS DE CATALOGAÇÃO NA PUBLICAÇÃO

(Biblioteca Virginie Buff D’Ápice da Faculdade de Medicina Veterinária e Zootecnia da Universidade de São Paulo)

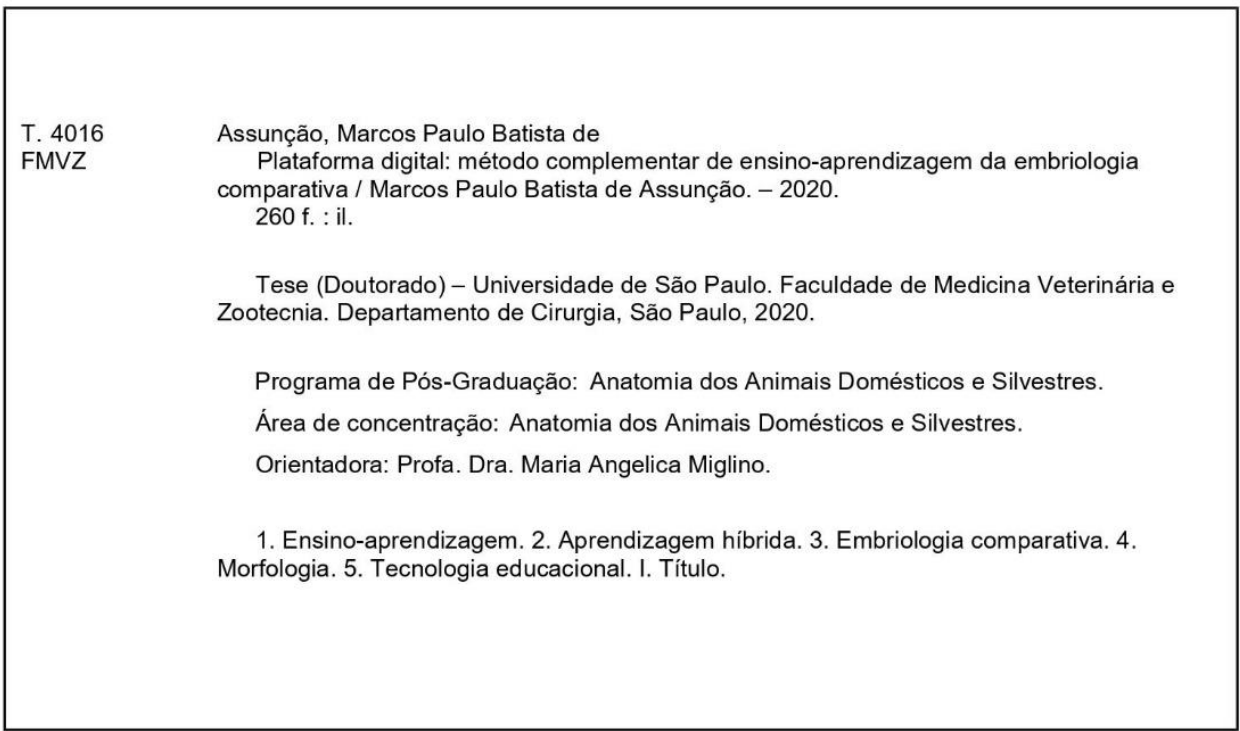

Ficha catalográfica elaborada pela bibliotecária Maria Aparecida Laet, CRB 5673-8, da FMVZ/USP. 
IImo(a). Sr(a).

Responsável: Maria Angélica Miglino

Área: Anatomia Dos Animais Domésticos E Silvestres

Título da proposta: "Plataforma digital: método complementar de ensino-aprendizagem da embriologia comparativa".

\section{Parecer Consubstanciado da Comissão de Ética no Uso de Animais FMVZ (ID 007278)}

A Comissão de Ética no Uso de Animais da Faculdade de Medicina Veterinária e Zootecnia da Universidade de São Paulo, no cumprimento das suas atribuições, analisou e APROVOU a Alteração do cadastro (versão de 28/outubro/2020) da proposta acima referenciada.

Resumo apresentado pelo pesquisador: "Nesta alteração de cadastro foi feito a alteração/modificação do título do trabalho, fato esse após correções sugeridas pelos membros da banca no exame de qualificação".

Comentário da CEUA: "Pesquisadora solicita adequação do título de acordo com comentários da banca de qualificação.".

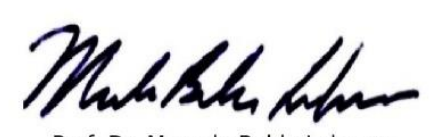

Prof. Dr. Marcelo Bahia Labruna

Coordenador da Comissão de Ética no Uso de Animais

Faculdade de Medicina Veterinária e Zootecnia da Universidade de São Paulo

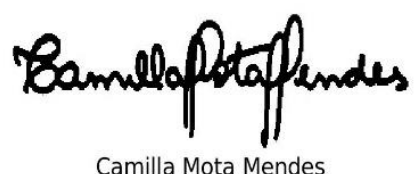

Camilla Mota Mendes

Vice-Coordenadora da Comissão de Ética no Uso de Animais Faculdade de Medicina Veterinária e Zootecnia da Universidade de São Paulo 
Autor: ASSUNÇÃO, Marcos Paulo Batista de

Título: Plataforma digital: método complementar de ensino-aprendizagem da embriologia comparativa

Tese apresentada ao Programa de PósGraduação em Anatomia dos Animais Domésticos e Silvestres da Faculdade de Medicina Veterinária e Zootecnia da Universidade de São Paulo para obtenção do título de doutor em Ciências.

Data: 17 de dezembro de 2020.

\section{Banca Examinadora}

Prof. a Dra. Maria Angélica Miglino

Instituição: Universidade de São Paulo - Julgamento:

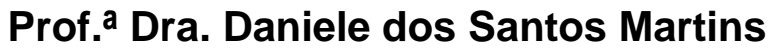

Instituição: Universidade de São Paulo - Julgamento:

Prof.o Dr. José Manoel dos Santos

Instituição: Faculdade de Medicina do ABC - Julgamento:

Prof. ํㅡ. Dr. Luiz Roberto Liza Curi

Instituição: Conselho Nacional de Educação - Julgamento:

Prof. - Dr. Mariano Guillermo Armando Del Sol Calderon

Instituição: Universidad de La Frontera - Julgamento: 


\section{DEDICATÓRIA}

Dedico este trabalho aos meus avós paternos José Machado de Assunção e Custódia Machado da S. Assunção os quais me criaram, me deram amor e carinho desde o início da minha vida (o que se estende até os dias atuais). A eles que me mostram a cada dia o melhor caminho a seguir, que me motivam, me traz calmaria, me ouvem e aceitam minhas escolhas, entendem as minhas falhas, os momentos de afastamento e também de reclusão, mas que me mostram ainda a importância de estudar, mesmo não tendo eles a mesma oportunidade no passado. Minha eterna gratidão por serem a minha inspiração e por sempre me aplaudirem na primeira fileira da arquibancada da vida, por não soltarem a minha mão mesmo em dias nublados e por serem o meu porto seguro. Eu amo vocês! 


\section{AGRADECIMENTOS}

Sempre achei essa a pior parte da tese para escrever, talvez porque a vida não se coloca em análise de regressão e não é pelo valor que descobrimos a significância das pessoas ao longo da nossa trajetória aqui na terra. Mas, ao mesmo tempo escrever estes agradecimentos é descrever também a feliz oportunidade de agradecer formalmente a todos aqueles que me encorajaram e me ajudaram direta ou indiretamente, para a conclusão de mais um passo de extrema importância na minha vida. Entretanto, me sinto lisonjeado e gratificado por essa oportunidade, pois onde há vontade, há chance de dar certo. $\mathrm{O}$ importante é plantar o que você quer colher e confiar no processo. Não se apegue ao que te apaga, às vezes a única coisa que importa é que você está tentando. Celebre suas pequenas vitórias, o que importa no fim é como você se sente dentro de sua própria busca pela realização de um sonho.

Sendo assim, começo agradecendo a Oxalá e a Nossa Senhora da Lapa por me guiarem, por me iluminarem, me darem sabedoria e tranquilidade para seguir em frente rumo aos meus objetivos e não desanimar com as dificuldades. Agradeço a Eles também por manterem minha avó Custódia e meu avô José Machado ao meu lado, com a saúde que eles se encontram hoje e que me tranquilizam dizendo: "calma, a sua hora vai chegar.".

À minha família, por entenderem e me apoiarem nessa importante decisão de deixálos um pouco longe fisicamente, mas não de coração. Sei que foram momentos difíceis, mas serão compensados no futuro; as minhas primas Giovana Damas (companheira de formação/a bióloga mais linda) e Eduarda Machado (futura médica veterinária) obrigado por não deixarem a essência que existe entre nós se abalar pela distância, ter vocês na minha vida e saber o quão torcem por mim, me faz grande a cada dia. À minha Mãe Mariza e seu cônjuge Carlos e ao meu Pai Roberto e sua cônjuge Adilza e as minhas irmãs (Meirielle e Natália) que sempre me direcionaram palavras de carinho, conforto e segurança, entenderam as minhas faltas, os momentos de desespero, estresse e angústia. À minha tia Sirleia e tia madrinha Ana Maria pela presença constante, mesmo que distante, ao longo desses anos. Obrigado a vocês por cada palavra de incentivo, por cada conselho, carinho e por sempre me ouvir por mais de uma hora em cada ligação de vídeo, naqueles momentos que eu 
mais me sentia sozinho. Aos meus padrinhos/madrinhas Paulo, Heliany e Edinha pelo apoio constante, por nunca me negarem qualquer tipo de ajuda.

Aos Professores Dr. Zenon Silva e Dra. Roseâmely Angélica de Carvalho Barros pela motivação, pela amizade construída ao longo da vida acadêmica e que vai muito além da ciência, por me permitir a amizade mais pura com o João Manoel ("acho que vou aceitar um café"), assim como por me permitirem trilhar esse caminho embasado nos seus ensinamentos. Já dizia a Prof. ㄹ Roseâmely "não perde tempo na vida safadeza" e complementava o Prof. ${ }^{\circ}$ Zenon "seu jacu"; amo vocês. Grato também pela convivência e pela amizade com todos os profissionais e alunos que passaram no LABANATH/UFG, hoje UFCAT, que contribuíram para o meu crescimento.

À Professora Dra. Maria Angélica Miglino por me aceitar para fazer parte dos seus grupos de pesquisas no Departamento de Cirurgia pelo PPGAADS como então doutorando, por superar cada adversidade imposta ao longo desse percurso, pela sua amizade e palavras de incentivo, por cada "puxão de orelha", bem como pela sua confiança no meu trabalho. Sou um grande admirador da pessoa humana que a senhora é, e, pela força que a senhora possui na busca de novos horizontes para a formação doutoral, dia-a-dia. À senhora Professora, meus mais sinceros agradecimentos, te desejo uma vida repleta de muita saúde e prosperidade.

Aos Professores: Dra. Rose Eli Grassi Rici, Dr. André Luis Rezende Franciolli, Dra. Taís Harumi de Castro Sasahara, Dr. Antônio Chaves de Assis Neto, Dr. Silvio Pires Gomes, Dr. Rafael Cardoso Carvalho, Dra. Marta Maria Antoniazzi, Prof. r. Carlos Alberto Gonçalves Silva Jared, aos Técnicos Sr. Ronaldo Agostinho da Silva e Diogo Nader Palermo, a cada servidor e a cada colega do PPGAADS-FMVZ-USP (em especial a Ms. Débora Garcia, Ms. Amanda Saragó, Ms. Luana Félix e Dra. Adriana Anunciação) pelas conversas, dicas/ensinamentos e bom-companheirismo.

Ao Laboratório de Ornitopatologia (FMVZ-USP) na pessoa do Professor Dr. Antônio J. Piantino Ferreira pela prontidão no fornecimento dos ovos embrionados utilizados no trabalho. 


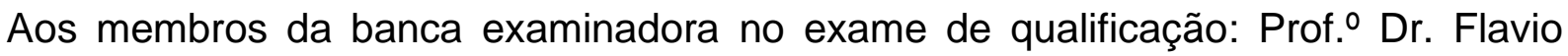
Vieira Meirelles, Prof. $\cong$ Dr. José Manoel dos Santos e Prof. $\cong$ Dra. Taís Harumi de Castro Sasahara que tanto contribuíram para que chegássemos nesta fase final.

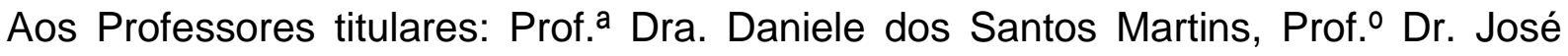
Manoel dos Santos, Prof. Dr. Luiz Roberto Liza Curi e Prof. Dr. Mariano Guillermo Armando Del Sol Calderon; aos Professores suplentes: Prof. ${ }^{a}$ Dra. Aparecida Maria

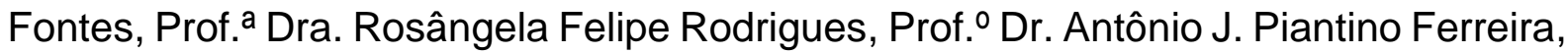
Prof. ․ Eduardo Cunha Farias e Prof. a Dra. Roseâmely Angélica de Carvalho Barros pela disponibilidade e pela boa vontade em aceitar o convite para participar da composição da comissão julgadora final deste trabalho.

Ao Professor Dr. Luís Fernando Angerami da Escola de Comunicação e Artes (ECAUSP) que junto a sua equipe de alunos e técnicos abriram as portas do estúdio do Departamento de Cinema, Rádio e TV para que fosse realizada as gravações das videoaulas inseridas na plataforma.

Ao meu novo amigo/irmão, que tornou minha estada em São Paulo mais fácil, leve e agradável: Bee (Carlos Eduardo Pereira), Engenheiro Agrônomo, amante da noite e da buatchy (me segura que vou cair kk), pai da Bethina, do lar, tatuado e companheiro em cada copo de cerveja. Obrigado grandemente pelo bom humor nas horas incertas, pelos conselhos, preocupação, pelos altos papos, pelos incentivos e me fazer enxergar mais longe, por cada churrasco, por me apresentar a sua família e cada um dos seus amigos, e por sempre confiar na nossa amizade. Ao Michel Marques pela boa amizade, por cada abraço e por cada momento juntos, e por sempre destacar a importância do nosso crescimento tanto pessoal quanto profissional da forma mais próspera. Ao Igor Bessera da Wedding Show pela oportunidade em fazer parte da sua equipe em Assessorias de eventos e pela amizade construída nesse percurso, bem como a cada pessoa extraordinária que me apresentou, possibilitando a construção de lindas amizades em São Paulo através do trabalho aos finais de semana.

As minhas amigas Ana Carolina Mendes, Juliana Demetriuk, Carina Alves, Adriana Mendes, Júlia Barbosa, Claudia Barbosa, Alice Caixeta, Millena Rodrigues, Lorena Caixeta, Bruna Campos, Kallyne dos Santos, Gisléria Sousa, Michele Borges, Prof. a 
Dra. Andreia Peixoto, Luciana Fernandes, Cida Fernandes, Gaby Rodovalho e Lorena Damas; e aos meus amigos Luiz Cotrim, Lucas Rezende, João Pedro, Romário Pereira, Felipe Brasil, Victor André e Marcelo Cortes só tenho a exata gratidão por se fazerem presentes mesmo que de longe, e por não deixarem perder a essência de uma amizade, e que tem tudo a ver comigo e compartilha de vários momentos. Ao Darci Rosa, Noêmia Rosa, Luana Rosa, Diogo Rosa e Romário Rosa obrigado por serem minha segunda família, obrigado pelo afeto, ajuda, cuidado e por sempre incentivar-me nesta empreitada. Dona Rute você faz parte dessa conquista também, pessoa que eu tenho a total admiração, que sempre me houve quando estamos juntos, que fica feliz em ver meu crescimento e que ao mesmo tempo me encoraja para os desafios da vida com sua sabedoria e resiliência, obrigado por sempre torcer pelo meu sucesso. Ms. Mônica Duarte e Dara Rúbia grato pela amizade construída na trajetória acadêmica e pela presença constante na Pós-graduação, cada conversa de conforto e sabedoria somou constantemente para chegar até o propósito final.

Ao Colégio Estadual “João Bernardes de Assunção" da cidade de Davinópolis Goiás (meu berço) por meio de cada colaborador e de cada Professor(a) que foram fundamentais no meu processo de formação inicial, tenho total respeito e admiração, grato pelas amizades construídas e por cada ensinamento adquirido no tempo que estive com vocês.

Agradeço ao Centro Avançado de Diagnóstico por Imagem (CADI-FMVZ-USP) pelos serviços prestados, ao Programa de Pós-graduação em Anatomia dos Animais Domésticos, programa este que tem o meu total reconhecimento pela excelência prestada e por abrir as portas da Universidade de São Paulo e da Faculdade de Medicina Veterinária e Zootecnia para trilhar a jornada acadêmica; à Comissão de Ética no Uso de Animais desta mesma IES pelo tempo dedicado na avaliação, resultando na aprovação do nosso trabalho.

O presente trabalho foi realizado com apoio da Coordenação de Aperfeiçoamento de Pessoal de Nível Superior - Brasil (CAPES) - Código de Financiamento 001. Coordenação essa que tem o meu profundo reconhecimento pelos serviços prestados em prol da educação brasileira. 
Finalmente, mais uma vez, agradeço há TUDO e à TODOS que de alguma forma me ajudaram em mais um ciclo da minha vida. Que não paremos por aqui, muito ainda virá. Muito obrigado. 
"Seria uma atitude muito ingênua esperar que as classes dominantes desenvolvessem uma forma de educação que permitisse às classes dominadas perceberem as injustiças sociais de forma crítica." 


\section{RESUMO}

ASSUNÇÃO, M. P. B. Plataforma Digital: método complementar de ensinoaprendizagem da embriologia comparativa. 2020. $260 \mathrm{f}$. Tese (Doutorado em Ciências) - Faculdade de Medicina Veterinária e Zootecnia, Universidade de São Paulo, São Paulo, 2020.

As ciências morfológicas são de fundamental importância, por exemplo, na formação de biólogos e de médicos veterinários. Sabendo dos avanços em tecnologia, desenvolver métodos como fonte de ensino complementar torna-se um pilar a mais para a construção dos saberes, permitindo que estudantes tenham maior acesso aos conteúdos, e se integrem aos recentes avanços educacionais. Este projeto em andamento tem como objetivo desenvolver material didático instrucional sobre a anatomia do desenvolvimento com foco no sistema cardiovascular de aves (Gallus gallus domesticus) a ser incorporado em uma plataforma de ensino em ambiente virtual. Entre tantos motivos éticos e econômicos, um dos fatores que tem determinado a prática complementar de ensino-aprendizagem, está atrelado à inovação tecnológica, as quais podem se revelar vantajosas, principalmente em tempos de pandemia como vivenciado nos dias atuais. Como resultado deste trabalho, apresentam-se nove aulas que constituem o módulo I de aprendizagem, e que estão hospedadas em uma plataforma digital, sustentando o propósito educacional e oferecendo aos discentes ferramentas úteis destinadas a construção dos saberes dinâmicos da embriologia veterinária. Foram produzidas também imagens relativas ao desenvolvimento macroscópico de aves domésticas em alto relevo em aspecto 3D, mediante a utilização de Photoshop. Estas estão disponibilizadas em formato de atlas em arquivo PDF. Concluímos que o presente trabalho cria um auxílio pedagógico que pode mitigar as dificuldades encontradas no ensino da embriologia animal, que compõem a grade curricular dos cursos de graduação das áreas de agrárias e/ou biológicas.

Palavras-chave: Ensino-aprendizagem. Aprendizagem híbrida. Embriologia comparativa. Morfologia. Tecnologia educacional. 


\begin{abstract}
ASSUNÇÃO, M. P. B. Digital Platform: complementary teaching-learning method of comparative embryology. 2020. 260 f. Tese (Doutorado em Ciências) - Faculdade de Medicina Veterinária e Zootecnia, Universidade de São Paulo, São Paulo, 2020.

Morphological sciences presents fundamental importance, for example, in terms of training biologists and veterinarians. Knowing the advances in technology, the development of methods as a source of complementary education becomes an additional pillar for the construction of knowledge, allowing students to have greater access to content and integrate them with recent educational advances. This ongoing project aims to develop instructional teaching material about the developmental anatomy, with a focus on the cardiovascular system of Gallus gallus domesticus to be incorporated into a teaching platform in a virtual environment. Among many ethical and economic reasons, one of the main factors that have determined the complementary teaching-learning practice is linked to technological innovation, which can prove to be advantageous especially in times of pandemic as experienced today. As a partial result of this work the nine classes that constitute module I of learning is presented. These classes are hosted in digital Platform, supporting the educational purpose and offering students useful tools for the construction of the dynamic knowledge of veterinary embryology. Images related to the macroscopic development of domestic birds in high relief and with a 3D aspects were also produced using Photoshop. They are available in atlas format in PDF file. The present work creates a pedagogical aid that can mitigate the difficulties found in the teaching of animal embryology, which make up the curriculum of undergraduate courses in agrarian and/or biological areas.
\end{abstract}

Keywords: Teaching-learning. Blended Learning. Comparative Embryology. Morphology. Educational Technology. 


\section{LISTA DE FIGURAS}

Figura 1 - Fluxograma referente a organização pedagógica dos capítulos que contemplam o módulo de aulas I, seguindo a cronologia de ocorrência dos eventos envolvidos no desenvolvimento embrionário

Figura 2 - Fotodocumentação dos embriões de aves (Gallus gallus domesticus) com intervalo de 1 a 3 dias do desenvolvimento 52

Figura 3 - Fotodocumentação, vista lateral esquerda, dos embriões de aves (Gallus gallus domesticus) com intervalo de 4 a 6 dias do desenvolvimento . .52

Figura 4 - Fotodocumentação da vista lateral esquerda, dos embriões de aves (Gallus gallus domesticus) no intervalo de 7 a 9 dias do desenvolvimento 53

Figura 5 - Fotodocumentação, vista lateral esquerda, dos embriões de aves (Gallus gallus domesticus) no intervalo de 10 a 12 dias do desenvolvimento

Figura 6 - Fotodocumentação, vista lateral esquerda, dos embriões de aves (Gallus gallus domesticus) durante o intervalo de 13 a 15 dias do desenvolvimento.

Figura 7 - Fotodocumentação, vista lateral esquerda, dos embriões de aves (Gallus gallus domesticus) com intervalo de 16 a 18 dias do desenvolvimento 55

Figura 8 - Fotodocumentação, vista lateral esquerda, dos embriões de aves (Gallus gallus domesticus) com intervalo de 19 a 21 dias do desenvolvimento

Figura 9 - Print da aba inicial da plataforma EAD GURU para acesso ao painel de controle. .56

Figura 10 - Página inicial de boas-vindas à plataforma "Embriologia comparativa" ...57

Figura 11 - QR CODE para acesso a plataforma "Embriologia comparativa"

Figura 12 - Representação da aba de registro cadastral na plataforma "Embriologia comparativa" .58

Figura 13 - Página para realização da matrícula acerca do produto disponível na plataforma "Embriologia comparativa" 59

Figura 14 - Página de direcionamento para os cursos disponíveis na plataforma "Embriologia comparativa"

Figura 15 - Aba, meus cursos, disponível na plataforma "Embriologia comparativa"

Figura 16 - Organização do percurso formativo referente ao módulo I Desenvolvimento embrionário: conceitos gerais e aspectos morfológicos disponível na plataforma "Embriologia comparativa" 


\section{LISTA DE QUADROS}

Quadro 1 - Idade (dias) e peso corporal (g) dos espécimes de Gallus gallus domesticus . .51 
1 INTRODUÇÃO

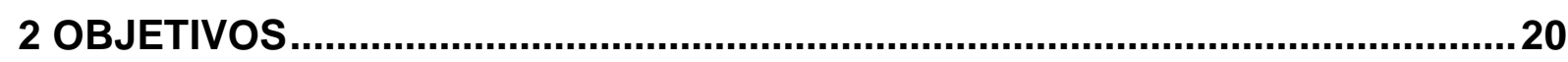

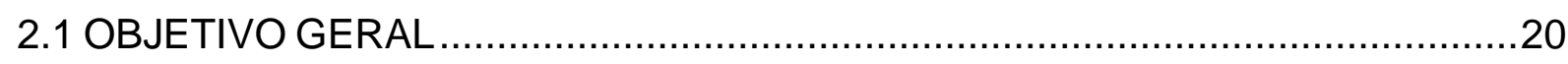

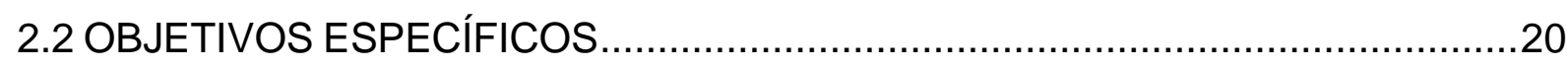

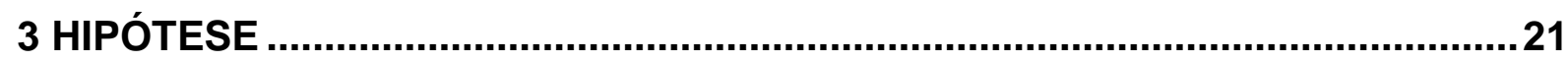

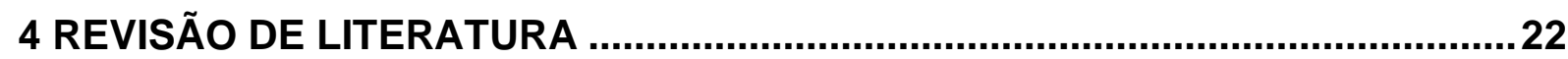

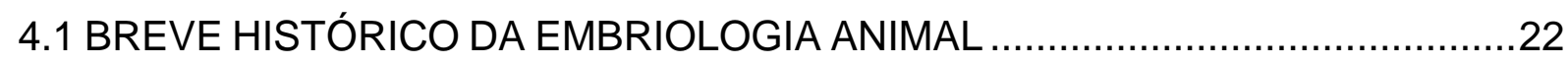

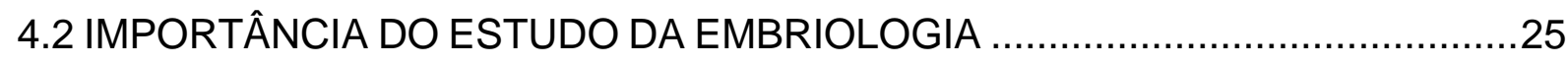

4.3 FORMAÇÃO DO EMBRIÃO EM AVES DOMÉSTICAS....................................26

4.4 EMBRIOLOGIA DO SISTEMA CARDIOVASCULAR EM ANIMAIS

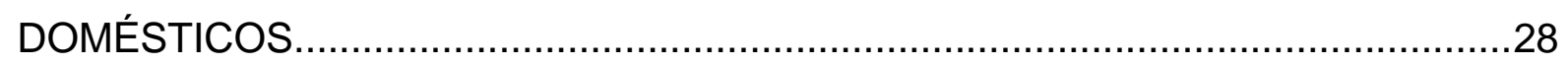

4.5 A UTILIZAÇÃO DE ANIMAIS EM EXPERIMENTAÇÃO ......................................31

4.5.1 Embriões de aves como modelo de estudo ................................................33

4.6 MÉTODOS COMPLEMENTARES DE ENSINO DA EMBRIOLOGIA ...................34

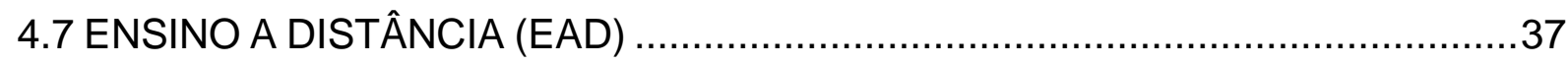

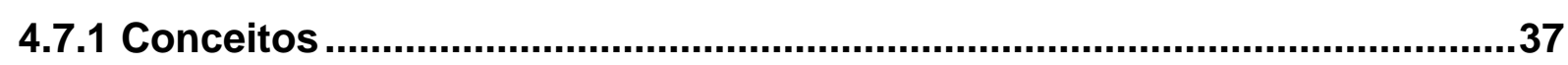

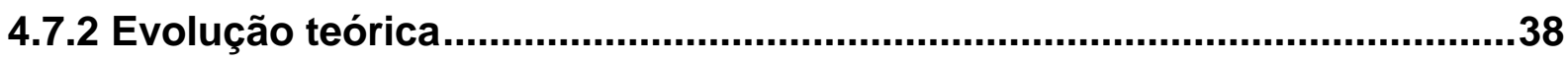

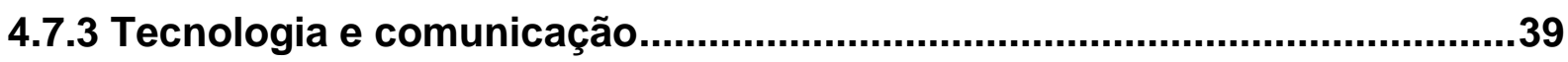

4.7.4 Ensino superior e o ensino a distância (EaD) ............................................40

4.7.5 Integração e colaboração no Ensino a distância (EaD) ................................41

4.7.6 O EaD como motor da educação em tempos de COVID-19.........................43

5 MATERIAL E MÉTODO

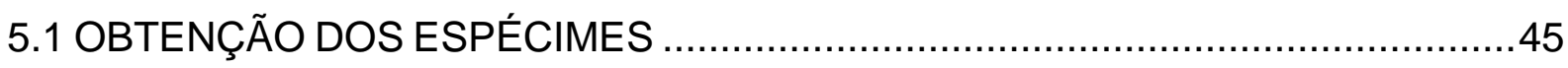

5.2 DADOS BIOMÉTRICOS E CONSERVAÇÃO DOS ESPÉCIMES ........................45

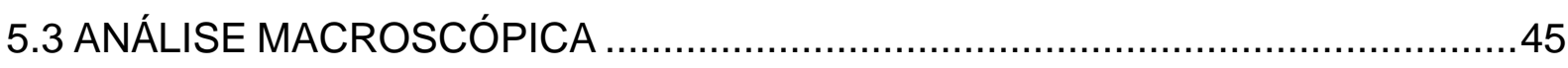

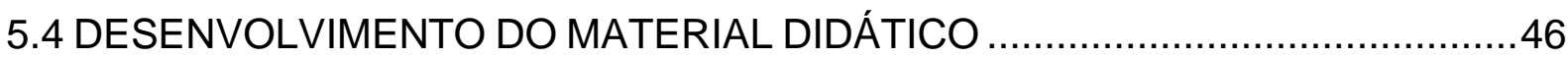

5.4.1 Organização do módulo e seleção do conteúdo .........................................46

5.4.2 Transposição didática das imagens para o desenvolvimento do atlas macroscópico intitulado "Embriologia veterinária" ...............................47

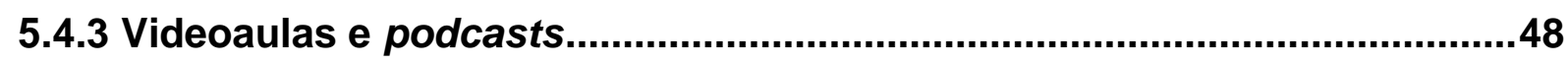

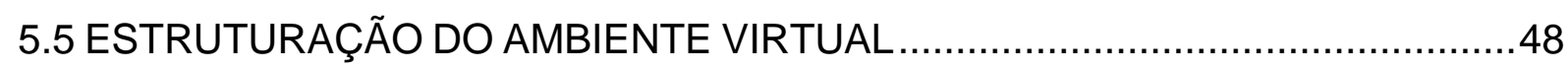

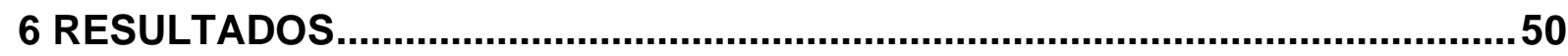




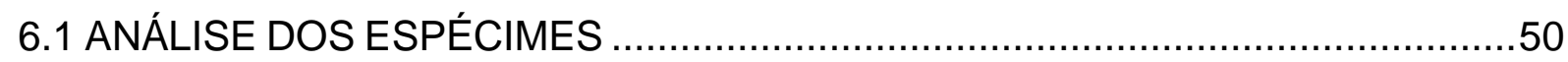

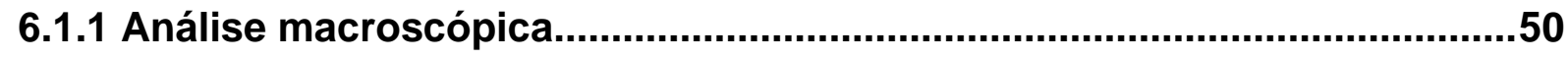

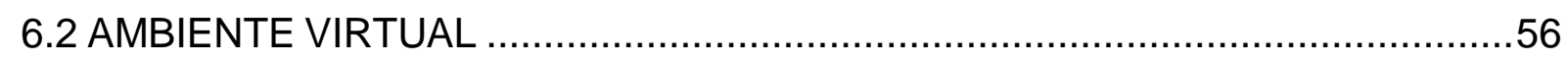

6.2.1 A criação da plataforma digital .............................................................56

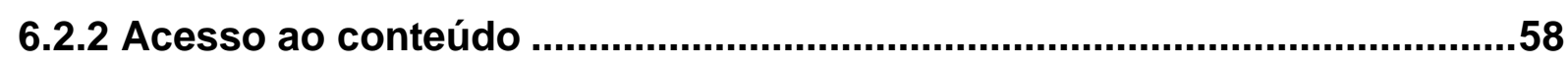

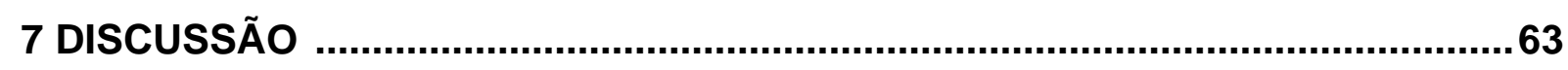

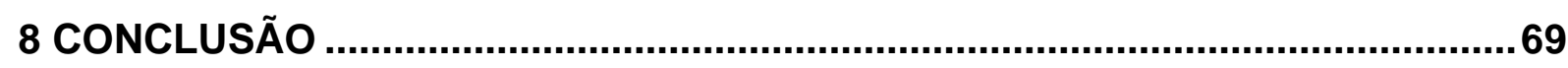

REFERÊNCIAS..................................................................................

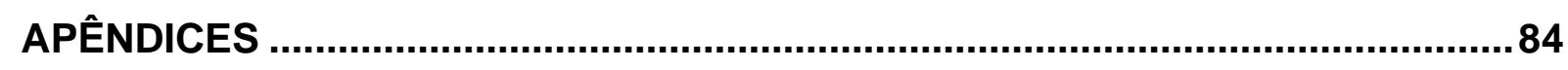

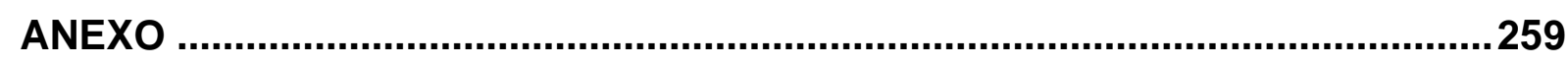




\section{INTRODUÇÃO}

O estudo do desenvolvimento animal apresenta-se como uma função indispensável à perpetuação das espécies e à continuidade da vida. Todo seu conhecimento integra as ciências morfológicas e é abordado pela Embriologia, ciência considerada experimental ou descritiva desde a antiguidade, e que se dedica ao estudo das diferentes fases transcorridas entre a fecundação e o nascimento (MOUL et al., 2017).

Sabendo da complexidade desta ciência, métodos tradicionais de ensino baseados em aulas teóricas e livros-textos, sem uma sequência instantânea exibida por imagens reais e/ou ilustrativas relativas à um conteúdo estruturalmente representativo, não se constitui como a melhor maneira de complementar o aprendizado do aluno (MAIA, 2017). As ciências morfológicas vêm passando por importantes reformulações em diversas Instituições, tornando-se inquestionável o desenvolvimento de competências e habilidades que permitam estabelecer relações entre as partes e o todo de um processo biológico (HEYLINGS, 2002; KRONTIRISLITOWITZ, 2003; JOTTA, 2005; DUMM, 2006; HECKLER; SARAIVA \& FILHO, 2007; DRAKE, 2007; MELLO, 2009; CASTRO et al., 2011).

Mudanças na maneira de ensinar morfologia, abordando a tendência crescente direcionada à aprendizagem integrada à sistemas computacionais, permitem aos estudantes ter maior acesso aos recentes avanços da tecnologia educacional (MORAES \& PEREIRA, 2010; CASAS \& AZEVEDO, 2017). Para alguns, o ensino online é visto com desconfiança retrógada. Entretanto, o mesmo apresenta-se como uma parte importante do futuro modelo de ensino-aprendizagem, constituindo uma combinação da tecnologia educacional moderna, e de conceitos do ensino tradicional, para formar um modelo adequado às necessidades educacionais (JI \& SUN, 2019; ZHENG, 2020; YU, 2020).

Com a irrupção do novo corona vírus causador da doença COVID-19 em Wuhan, China, no final de 2019, situações de emergência na saúde pública foram decretadas, o surto foi considerado como o mais amplo em escopo de infecção, sendo o mais difícil de ser controlado, afetando todos os setores. Sua disseminação ocorreu muito rapidamente para todo o mundo, e, assim, diversos países e regiões tiveram que optar pelo isolamento social, e, consequentemente, transformar suas atividades 
de ensino presencial para dar sequência ao processo de ensino-aprendizagem (ROJAS et al., 2020).

Potencializado pelo distanciamento social, a alternativa mais efetiva e adotada no âmbito educacional foi a implementação do ensino à distância. As aulas online e os materiais didáticos como fonte complementar de ensino, apresentaram-se como facilitadores da aprendizagem, constituindo assim um dos recursos mais utilizados durante a pandemia (ZHOU et al., 2020). Muitas Instituições de ensino, professores e alunos tiveram que se adaptar ao novo sistema. Mesmo em "tempos normais", dados do Inep/MEC apontaram que, em 2018, ocorreu em série histórica 7,1 milhões de vagas ofertadas em cursos a distância. Segundo a Associação Brasileira de Mantenedoras de Ensino Superior (ABMES) a projeção para 2023 é que mais alunos se matricularão em cursos de modalidade EaD do que, nos cursos presenciais.

A utilização de recursos digitais, bem como de plataformas virtuais podem ser grandes aliadas do processo de ensino-aprendizagem, apresentando forte poder de transformação social. Em passos largos, o ensino à distância possibilita o acesso dos estudantes aos mais diferentes veículos de comunicação, diversifica a maneira de obter informações envolvendo pessoas que dificilmente poderiam cursar o Ensino Superior presencial. Além disso, contribui para a revolução de estratégias pedagógicas e de quebra de paradigmas para os pesquisadores e professores (SAMAR \& AVILA, 2007; FERREIRA \& KEMPINAS, 2010; FERREIRA, 2011; SANTAROSA \& STRUCHINER, 2011; ROXO, 2015; BARRY, 2016; MILLER \& LEWIS, 2016).

Entre as mais diversas espécies de animais domésticos existentes, abordamse neste estudo o desenvolvimento embrionário de aves (Gallus gallus domesticus). Para tanto, o presente trabalho apresenta-se como uma proposição complementar e inovadora de acesso às fontes de material educativo via plataforma digital, uma vez que a facilidade do acesso não será apenas destinada ao público, mas, sobretudo, ao editor para sua contínua atualização, correção e adição de informações sob demanda, eliminando assim a inconveniente limitação temporal da enumeração de edições dos livros impressos ou e-books clássicos da área. 


\section{OBJETIVOS}

\subsection{OBJETIVO GERAL}

Desenvolver material didático instrucional sobre a anatomia do desenvolvimento com foco no sistema cardiovascular de aves (Gallus gallus domesticus) a ser incorporado em uma plataforma de ensino em ambiente virtual.

\subsection{OBJETIVOS ESPECÍFICOS}

- Analisar e descrever a morfologia macroscópica do desenvolvimento embrionário com ênfase no sistema cardiovascular de aves (Gallus gallus domesticus);

- Por transposição didática, ilustrar as fases transcorridas dos espécimes em desenvolvimento, bem como desenvolver videoaulas e podcasts que favoreçam o aprendizado do aluno;

- Estruturar conteúdo acerca do desenvolvimento embrionário de aves, bem como criar e oferecer uma plataforma digital como método complementar ao processo de ensino-aprendizagem;

- Auxiliar na formação de estudantes e possibilitar o estudo das correlações entre Embriologia e Anatomia de maneira a oportunizar o estudante a lidar com os conhecimentos, correlacionando-os e analisando seu significado. 


\section{HIPÓTESE}

O ensino da anatomia do desenvolvimento de aves domésticas com foco no sistema cardiovascular possa ser realizado na modalidade a distância (EaD), entendida como uma proposição de ensino complementar, cumprindo de maneira eficiente o propósito de minimizar a utilização de animais submetidos à experimentação, auxiliar na formação de novos profissionais e oferecer ao discente a construção de um conhecimento integrado. 


\section{REVISÃO DE LITERATURA}

Os dados bibliográficos incluem publicações que descrevem achados os quais serviram como base para estabelecer análise comparativa e descritiva do padrão de desenvolvimento macroscópico do sistema cardiovascular das aves, no sentido de criar condições para melhor compreensão, interpretação dos resultados e elaboração de conteúdo a serem disponibilizados na plataforma digital de ensino em anatomia do desenvolvimento comparada.

No entanto, a revisão de literatura foi dividida nos seguintes tópicos: breve histórico da embriologia animal; importância do estudo da embriologia; formação do embrião aves domésticas; embriologia do sistema cardiovascular em animais domésticos; a utilização de animais em experimentação; métodos complementares de ensino da embriologia e ensino a distância (EaD).

\subsection{BREVE HISTÓRICO DA EMBRIOLOGIA ANIMAL}

Ao longo dos anos, o deslumbramento pela maneira a qual a "vida" se desenvolve, deu origem à diversos questionamentos sob a complexidade deste processo, e suas inter-relações. Gilbert et al., (2006) relataram que documentos egípcios e sânscritos já continham descrições de embriões e que grande parte dos mais diversos e antigos filósofos se interessavam pela embriologia. As buscas pela compreensão destes mecanismos são pertinentes e discutidas em meio à sociedade contemporânea. Tratando-se dos animais domésticos, estes são de extrema importância devido à sua grande variedade e abrangência (MENEZES, 2001; CONCEIÇÃO, 2008).

De acordo com Demócrito (455-370 a.C.) o sexo de um indivíduo era determinado pela origem do espermatozoide, ou seja, os machos seriam provenientes do testículo direito e as fêmeas do testículo esquerdo. No entanto, esta hipótese foi modificada por Pitágoras, Hipócrates e Galeno, uma vez que para a ciência, a definição do sexo sempre foi privilégio do homem; os filósofos em sua maioria colocavam as fêmeas entre os homens e os animais, sendo que os machos eram originados de um espermatozoide de alto potencial que provinha do testículo direito.

O primeiro embriologista conhecido da época foi o filósofo grego Aristóteles (384-322 a.C.) por realizar os primeiros estudos embriológicos de maneira sistemática 
e organizada. Ele descreveu o desenvolvimento embrionário de animais e dentre eles o desenvolvimento embrionário de galinha, para o qual fez a mais importante descoberta; o embrião desenvolve seus sistemas de órgãos gradualmente. Na obra "A geração dos Animais" (350 a.C.) identificando os diferentes tipos pelos quais os animais nasciam podendo ser pela oviparidade, viviparidade ou ovoviviparidade, descreveu ainda os dois grandes padrões de clivagem embrionária, como sendo: holoblástica ou meroblástica, além de descrever as funções da placenta, e do cordão umbilical os quais para os bovinos, por exemplo, possuíam funções fundamentais para nutrição fetal.

Os estudos acerca da embriologia se desenvolveram muito lentamente juntamente com a anatomia descritiva. A primeira descrição anatômica de útero prenhe de porcas foi feita por Kopho, no início do século XIII em um de seus trabalhos Anatomio Porci, para o qual utilizou porcos como modelos experimentais. A partir disso, com o Renascimento, descrições anatômicas ficaram cada vez mais reconhecidas, fato que coincidiu com a impressão de livros por Johann Gutenberg. A principal publicação que serviu de marco para embriologia comparativa foi datada de 1600, pelo renomado anatomista italiano da época Hieronymus Fabricius de Acquapendente (1533-1619) o qual descreveu e ilustrou a anatomia macroscópica de embriões e suas membranas na obra De Formato Foetu. Entretanto, Acquapendente não foi o primeiro a fazer isso; o anatomista italiano Bartolomeu Eustáquio (15141574) havia previamente publicado ilustrações de embriões de cães e ovelhas no ano de 1552. É possível reconhecer o nome de Acquapendente em Bursa Fabricii na porção imunológica do intestino de aves, e de Eustáquio na trompa de Eustáquio, hoje tratada como epônimo.

Os achados de Eustáquio, Fabricius e outros cientistas da época forneceram ideias primordiais para sanar as dúvidas pertinentes às questões de desenvolvimento dos órgãos, naquilo que se refere a seu formato em sua fase inicial até a maturação. Entretanto, deixou o enigma básico sem resposta: "como e onde se originam os embriões mamíferos?". Foi a partir daí que o médico italiano Marcelo Malpighi (16281694) mediante o desenvolvimento do microscópio por Zacarias Janssen em 1590, publicou os primeiros relatos sobre o desenvolvimento de aves (Gallus gallus domesticus), criando a partir daí uma revolução na embriologia descritiva. Com isso ele identificou o sulco neural, os somitos e a circulação de sangue nas artérias e veias do vitelo (GILBERT, 2006). 
Em meados do século XIX após a revolução dos aspectos embriológicos, muitos nomes da ciência se destacaram, entre eles Karl Ernst von Baer, Richard Owen e Ernst Haeckel. Von Baer (1828) e Haeckel (1866) realizando grandes estudos comparativos com séries ontogenéticas de embriões vertebrados, puderam observar importantes aspectos do desenvolvimento correlacionando-os com a origem e com a existência de planos sistêmicos comuns aos diversos grupos de animais (RICHARDSON \& KEUCK, 2002).

Mais tarde, as ideias elaboradas por Von Baer; Richard Owen (1840) segundo Hall (1992), discutiam questões sobre a analogia e a homologia do desenvolvimento embrionário. $\mathrm{O}$ autor ainda relatou que Richard Owen utilizou os conceitos abordados por Karl Ernst von Baer (1792-1876) para apresentar a existência de um plano de desenvolvimento em comum às diferentes espécies. Acreditava-se que a partir deste plano resultava a morfologia típica comum, e, as derivadas modificações que ocorriam posteriormente partindo para uma investigação mais aprofundada. Foi von Baer em 1827 que ao abrir o "Ovo de Graaf" encontrou um ponto amarelo, e o examinou mediante um microscópio óptico. Assim, o "ovo" de mamíferos foi identificado.

Ao identificar o óvulo de mamíferos, von Baer medrou às investigações tomando como referência os achados de Christian Pander (1794-1865) em embriões de galinha, e, descreveu a notocorda pela primeira vez. Ainda no século XIX, o biólogo alemão von Bischoff (1807-1882) em minuciosas observações feitas por meio de colorações específicas e técnicas microscópicas, detalhou os estágios de clivagem em espécies de coelhos. Já no homem e em espécies domésticas este processo foi descrito pelo anatomista e fisiologista suíço von Kölliker (1817-1905), o qual em 1861 publicou o livro-texto sobre a embriologia humana e animal.

Entre o final do século XIX e início do século XX, os embriologistas americanos Beecher Wilson; Hunt Morgan e Heinrich Boveri (1856-1915) descobriram que a hereditariedade residia no citoplasma ou até mesmo no núcleo celular do ovo fecundado, despertando curiosidades genéticas por meio da embriologia. A ideia era baseada nos alelos cromossômicos os quais foram estudados por Beecher Wilson e Maria Stevens (1861-1912), dando continuidade aos trabalhos de Boveri, correlacionando as questões fenotípicas às propriedades do núcleo. Até então, ambas as especialidades não eram tratadas como distintas. Foi Morgan em 1920, quem propôs e definiu a genética como divergente da embriologia. Para Morgan (1920) a 
genética estudava a transmissão das características hereditárias, enquanto que a embriologia a expressão destas (HYTTEL, SINOWATZ \& VEJLSTED, 2010).

Para tanto, a embriologia como ciência apresenta-se em desenvolvimento exponencial. Integrada nos currículos dos cursos de Medicina, de Medicina Veterinária e de Ciências Biológicas, a embriologia vem fazendo seu caminho. Em 1924 foi publicado por Zeitzschmann o livro-texto de Embriologia, entre outros (embora poucos). Dentre as obras literárias disponíveis para acesso na época, destacaram-se as obras Embryology of the Pig de Bradley M. Patten, e a Biologia do Desenvolvimento de Scott F. Gilbert, sendo que este último contemplava a Embriologia Comparada. Baseada na linguagem grega e latina a "Nomenclatura Embriológica" surgiu a fim de facilitar os mais diferentes termos utilizados nesta especialidade da ciência, e, mesmo passando por modificações ao longo dos anos, utiliza-se a mesma como base até os dias atuais.

\subsection{IMPORTÂNCIA DO ESTUDO DA EMBRIOLOGIA}

A embriologia representa um caminho vasto para a compreensão das relações filogenéticas entre os diferentes grupos de animais, e, fundamental para a perpetuação das espécies. Todo estudo ligado a esta ciência gera forças às discussões sobre o desenvolvimento dos animais quando comparados simultaneamente, deixando mais claro e conciso os estágios referentes a cada etapa embrionária para a formação dos sistemas funcionais do indivíduo (GILBERT, 2003).

Para Hall et al., (1992) os componentes ambientais possuem uma forte ligação aos processos de desenvolvimento, interagindo e representando desde o meio celular até o ambiente externo. Para além disso, tornam-se extremamente dependentes das condições ambientais ao meio nos quais estão inseridos. Já os mecanismos epigenéticos representam a conjunção de fatores genéticos e não genéticos agindo nos diferentes níveis de organização do sistema de desenvolvimento. São eles que controlam e selecionam a expressão de genes ou a dissociação entre os tempos de expressão destes, para a produção das variantes fenotípicas que ocorrem.

Neste contexto, a expressão gênica reflete no desenvolvimento e na formação "padrão" do embrião. Para Eslack (1993) o processo de formação é controlado por mecanismos conservados e são compartilhados entre os grandes e variados grupos de animais. As modificações ocorrentes nestes padrões são as principais causas 
responsáveis pelas variações observadas entre as espécies domésticas (RICHARDSON, 1999).

Com a existência e a necessidade intrínseca de interações entre partes nas quais se observa a não-correspondência entre genótipo-fenótipo, é que se pode estabelecer as inter-relações por meio da embriologia, abordando questões referentes ao desenvolvimento individual (diferenciação, morfogênese, funcionalidade e crescimento). Por outro lado, podem ser elencados como as variações em processos de desenvolvimento, podendo ser observadas em níveis macroscópicos, de forma a gerar a diversidade de planos estruturais e morfológicos para caracterização do indivíduo.

\subsection{FORMAÇÃO DO EMBRIÃO EM AVES DOMÉSTICAS}

O desenvolvimento embrionário na maioria dos animais domésticos e outros vertebrados é bastante semelhante nas fases iniciais. Wolpert (2000) verificou que o desenvolvimento inicial das aves domésticas (Gallus gallus domesticus) é semelhante ao padrão encontrado para mamíferos, tanto na complexidade quanto no curso geral do desenvolvimento.

$\mathrm{Na}$ embriologia comparativa, ao avançar para outros estágios do desenvolvimento, processos tornam-se espécie-especificas, definindo padrões característicos para cada uma (GILBERT, 1995). Em termos específicos, as fases iniciais do desenvolvimento embrionário englobam todos os processos nos quais uma célula, o zigoto, dá origem ao concepto, o qual ao nascimento, tem a capacidade de adaptar-se à vida pós-natal. Hafez (1982) propôs que o desenvolvimento embrionário inicial antes que ocorra a ativação gênica, é passível de prescrição por meio dos produtos maternos em estocagem, onde por vez, o melhor indicador de maturação do oócito é o desenvolvimento do embrião até a fase de blastocisto

O processo de clivagem do óvulo ocorre 3 horas após a fecundação iniciandose no oviduto da galinha em um formato discoidal (HAMBURGER \& HAMILTON, 1951). Segundo Wolpert (2000) tal evento resulta na formação do blastoderme que se localiza no topo de uma massa de vitelo, o qual passa a ser envolvido pelo albúmen e pela casca. A região central do blastoderme, situado sobre uma cavidade (espaço subgerminativo), é translúcida (zona pelúcida), já a região externa é mais escura (zona opaca). Após a postura do ovo, o embrião apresenta duas camadas de células: 0 
epiblasto (superior, originará o embrião) e o hipoblasto (inferior, originará estruturas extraembrionárias), dando início a fase da gastrulação (GILBERT, 1995).

O início de ocorrência da gastrulação se dá cerca de 6 a 7 horas de incubação, sendo marcado pelo desenvolvimento da linha primitiva (5 a 6 horas pós incubação), precursora do eixo anteroposterior. Ela representa a região onde as células do epiblasto estão proliferando e migrando para o interior, para baixo da camada superior (WOLPERT, 2000; MACHADO, 2006). A condensação de células formada na extremidade anterior é conhecida como nó de Hensen, que dará origem à notocorda. No decorrer da gastrulação ocorrem intensos movimentos de células e camadas celulares, que culminam com a formação dos três folhetos embrionários, sendo eles: endoderme, mesoderme e ectoderme. Da endoderme se originam o epitélio respiratório, a bexiga, o trato digestivo e seus derivados. A mesoderme dá origem ao sistema musculoesquelético, tecidos conjuntivos e outros órgãos internos como rins e coração. Já a ectoderme dá-se origem a epiderme, anexos e ao sistema nervoso (WOLPERT, 2000).

O desenvolvimento do embrião das aves é definido como anteroposterior, pois ocorre simultaneamente a gastrulação em regiões posteriores ao embrião e o início da neurulação se dá na sua região anterior (ALBERTS et al., 2006). Durante a neurulação, a ectoderme se separa em dois compartimentos distintos: ectoderme de revestimento (dará origem à epiderme e seus anexos) e ectoderme neural (formação do sistema nervoso).

A neurulação consiste na formação da placa neural na altura da linha média do embrião, que se invagina formando o sulco neural ao centro, com as pregas neurais nas laterais, tal evento ocorre após 20 horas de incubação. A invaginação provocada destina-se ao desenvolvimento do tubo neural que na sua porção mais anterior formará o encéfalo e na porção posterior à medula espinhal. As células contidas nas extremidades das dobras neurais se segregam e formam a crista neural. O embrião acompanhado da neurulação e do desenvolvimento da dobra cefálica, se dobra no lado ventral para formar o intestino, o que une os dois rudimentos do coração para formar um órgão localizado ventralmente em relação ao intestino.

A formação de somitos progride em uma direção posterior a uma velocidade de aproximadamente um par de somitos por hora. Em torno de dois dias após a postura o embrião já atingiu o estádio de 20 somitos, e em três dias, em torno de 40 somitos são formados, a cabeça está bem desenvolvida, o coração formado e os membros 
estão começando a se desenvolver. Ilhas de sangue (onde a hematopoese está ocorrendo) e vasos sanguíneos desenvolveram-se em tecidos extraembrionários sendo que esses vasos se conectam com aqueles do embrião para permitir a circulação com o batimento cardíaco. A fusão entre o córion e o alantoide resulta em uma intensa vascularização que se forma entre $04^{\circ}$ e $08^{\circ}$ dia do desenvolvimento embrionário de Gallus gallus domesticus. Nesse estádio, o embrião vira-se de lado e a cabeça está fortemente flexionada. O embrião obtém a sua nutrição pelas membranas extraembrionárias, que também fornecem proteção. O saco amniótico, cheio de fluido, fornece proteção mecânica; o córion envolve todo o embrião e fica imediatamente sob a casca; o alantoide recebe produtos excretórios e provê o sítio de troca de oxigênio e dióxido de carbono; o saco vitelínico envolve o vitelo/gema (WOLPERT et al., 2000).

No decorrer do desenvolvimento, antes da eclosão, os olhos e os ouvidos se desenvolvem a partir das vesículas ópticas e óticas, respectivamente. $\mathrm{O}$ embrião cresce em tamanho, os órgãos internos se desenvolvem, as asas, pernas e a ranfoteca são formados, e, penugens inferiores formam-se nas asas e no corpo. A eclosão ocorre aos 21 dias pós incubação do ovo (HAMBURGER \& HAMILTON, 1951).

\subsection{EMBRIOLOGIA DO SISTEMA CARDIOVASCULAR EM ANIMAIS DOMÉSTICOS}

Os processos dinâmicos que ocorrem ao longo do desenvolvimento do animal, são ocasionados por todo e qualquer aglomerado celular que pode resultar em uma determinada estrutura do futuro organismo. A exemplo disso é a formação do sistema cardiovascular. Embriologicamente, o coração é considerado como um tubo modificado, é um dos primeiros sistemas a formar e atingir seu "estado funcional" nas mais diversas espécies; o termo poderia ter sido modificado e reduzido apenas por sistema vascular (DI DIO, 2002). Pela terminologia anatômica o referido sistema é oficialmente denominado como um sistema que envolve todo o aparelho circulatório.

O sistema cardiovascular dos animais domésticos (DYCE, 2010), dos humanos (DI DIO, 2002) e outros vertebrados (STORER, 1989; HILDEBRAND, 1995) é caracterizado pela presença de um órgão oco, ou seja, o coração, pelas artérias, capilares, vênulas e veias, bem como de órgãos hematopoiéticos (formadores de sangue), além de um subsistema linfático composto por órgãos linfoides, troncos, 
ductos e linfonodos. Este sistema é considerado integrador, juntamente com o sistema nervoso e endócrino, por envolver direta ou indiretamente todos os órgãos de um ser vivo (STORER,1989; DI DIO, 2002).

Os sistemas cardiovascular e hematopoiéticos dos animais domésticos (DYCE, 2010) e outros vertebrados (HILDEBRAND, 1995) tais como os camundongos (JI, 2003; Mc GRATH, 2003), e os humanos (MOORE; PERSAUD, 2008) são os primeiros sistemas a se desenvolver no período da embriogênese (HYTTEL, 2010; XU; CLEAVER, 2011).

Durante as primeiras fases do desenvolvimento em animais domésticos, para Hyttel, Sinowatz \& Vejlsted (2010) o embrião é nutrido por difusão mediante o fluido secretado pelas glândulas uterinas. O desenvolvimento precoce do coração é fundamental devido ao rápido crescimento do embrião, com o seu crescimento e suas necessidades nutricionais o suprimento apenas pela difusão torna-se insuficiente, sendo, necessário o desenvolvimento de um sistema que distribua oxigênio, nutrientes e remova o gás carbônico, bem como os metabolitos do indivíduo para a sobrevivência e crescimento das espécies no período inicial pós-implantação (HILDEBRAND, 1995; SADLER, 2005).

A indução da região cardiogênica é iniciada pelo mesoderma subjacente às futuras células cardíacas, por meio da liberação de BMPs que juntamente com a inibição da expressão de WNT induz a expressão do gene NKX2.5 dominante para o desenvolvimento do sistema cardiovascular (EVANS \& SACK, 1973).

O sistema cardiovascular propriamente dito tem sua origem mediante a camada germinativa mesodérmica, especificamente do mesoderma lateral. Inicialmente, ocorre a diferenciação do mesoderma presente na parede do saco vitelínico, formando os angioblastos, que formarão as células endoteliais, e, as células precursoras das células sanguíneas (HYTTEL, SINOWATZ \& VEJLSTED, 2010) apresentando as maiores variações individuais e também as mais adaptáveis, durante a evolução dos vertebrados, assumindo formas diversificadas ao longo do desenvolvimento embrionário e entre os mais diferentes táxons (HILDEBRAND, 1995).

Mediante os aspectos de desenvolvimento do sistema cardiovascular que envolvem uma condensação de células mesenquimais, junto ao celoma pericárdico, os cordões cardiogênicos vão se constituindo e dão origem aos tubos endocárdicos. O pregueamento cefálico-caudal do saco amniótico implica diretamente no deslocamento, torção e posicionamento gradual do coração em desenvolvimento, 
enquanto o lateral leva à fusão gradativa dos tubos endocárdicos. Os tubos cardíacos antes da sua fusão são envoltos por mesênquima esplâncnico, dando constituição ao manto mioepicárdico. Neste processo ainda ocorre a migração de células sobre o tubo endocárdico, formando assim o epicárdio. Dessa forma, a parede do tubo passa a constituir-se de três camadas e, essas camadas são anatomicamente denominadas de endocárdio, miocárdio e epicárdio (ALMEIDA, 1999). Mediante a constituição das camadas do tubo, é notório a formação de uma alça acompanhada da septação. Para Hyttel, Sinowatz \& Vejlsted (2010) a formação do septo no coração, em parte, se origina do desenvolvimento do tecido de coxim endocárdico no canal atrioventricular e na região conotruncal.

Durante a vida fetal, a circulação é completamente diferente, visto que o embrião está ligado à placenta (nos mamíferos); por isso, assim como descrito por SADLER (2010), algumas mudanças circulatórias são observadas após o nascimento como o fechamento das artérias umbilicais, da veia umbilical, do ducto venoso, do ducto arterial e do forame oval.

O arranjo geométrico dos capilares maternos e fetais em relação ao fluxo sanguíneo na área de trocas materno-fetais da placenta pode ocorrer por fluxo concorrente, contracorrente e corrente cruzada simples, dupla ou multivilosa (LEISER; KAUFMANN, 1994). O saco vitelínico, juntamente com o âmnio, córion e alantoide segundo Vejlsted (2010) é um anexo extraembrionário presente em embriões de todos os vertebrados, sendo especialmente desenvolvido nos peixes, répteis aves e nãoaves (GALDOS, 2010).

Em termos específicos, o saco vitelínico também é responsável pela produção de células sanguíneas e endoteliais que possibilita a construção do plexo vascular no embrião (PALIS; YOUDER, 2001; CHOI, 2002; BARON, 2003; McGRATH; PALIS, 2005; HYTTEL, 2010). Todo sistema cardiovascular é moldado por sugestões de direção que envolvem o fator de crescimento do endotélio e outros fatores determinantes (SADLER, 2010). Nos embriões humanos, os vasos sanguíneos começam a se desenvolver meados da terceira semana e sua ocorrência se dá por meio de dois processos fundamentais: a vasculogênese e a angiogênese (MOORE; PERSAUD, 2008). Nos equinos a formação de vasos sanguíneos inicia após o décimo quarto dia de gestação (SHARP, 2000). Dados de Wall et al., (2008) referente a embriões de ratos com 8-10 dias de gestação (estágio 5-30 somitos) mostra o plexo vascular bem desenvolvido e já apresentando circulação funcional. 
Em animais domésticos como em caninos, felinos, bovinos, equinos e suínos (NELSEN, 1953; ALMEIDA, 1999; HYTTEL, 2010) e em humanos (MOORE; PERSAUD, 2008), o desenvolvimento do sistema cardiovascular consiste de um tubo cardíaco, ligado em uma das extremidades com a aorta dorsal e na outra com um conjunto de três veias, sendo as veias vitelínicas, umbilicais e as veias cardinais. Em bovinos o cordão umbilical constitui-se de duas artérias, duas veias e de um ducto alantoide (MIGLINO, 1991). Em gatos e humanos o endotélio do saco vitelínico permite a passagem de proteínas e células sanguíneas para as necessidades acerca do desenvolvimento do embrião devido a sua morfologia fenestrada (TIEDMANN; MINUTH, 1980). Para tanto, aos 22 dias nos equinos, por exemplo, formam-se as câmaras cardíacas, ou seja, átrios e ventrículos que se diferem pela espessura das paredes cardíacas, sendo os ventrículos mais espesso (FRANCIOLLI, 2012). Franciolli (2012) verificou ainda por análise microscópica camadas como o epicárdio, miocárdio e endocárdio, apresentando septação cardíaca completa em torno dos 38 dias de gestação.

Nas aves (Gallus gallus domesticus) o sistema cardiovascular é extensivamente remodelado no decorrer do desenvolvimento. Na espécie, o coração se forma inicialmente a partir do disco embrionário em formato de tubo emparelhado ao segundo dia do período embrionário. Mais tarde, pequenas regiões se diferenciam em "ilhas" sanguíneas no mesoderma embrionário, sendo elas a principal contribuição de suprimento para os vasos sanguíneos e glóbulos vermelhos fetais. As "ilhas" de sangue conectam-se para a formação dos vasos que suprem o tubo cardíaco. O embrião a partir disso cresce e se desenvolve muito rapidamente. No sétimo dia o coração está completamente formado, ocorre o dobramento do disco e transporta o órgão para a posição anatômica correta na cavidade toracoabdominal (HAMBURGER \& HAMILTON, 1951; HILL, 2020).

\subsection{A UTILIZAÇÃO DE ANIMAIS EM EXPERIMENTAÇÃO}

Historicamente, a utilização de animais ou parte deles em experimentação é citada por filósofos pré-socráticos como Pitágoras desde 500 a.C., e pode ser entendida como a prática de realizar intervenções em animais in vivo ou submetidos ao abate (no caso, da obtenção de muitos embriões) com a finalidade de beneficiar o conhecimento acadêmico e científico. Embora a prática de experimentação com 
animais seja realizada desde a antiguidade, tais procedimentos podem ser capazes de ferir o lado sensitivo da humanidade, despertando atualmente discussão entre a comunidade acadêmica e a sociedade protetora dos animais (MATTHIESSEN, 2003; SCHATZMAYR, 2008). Neste contexto, existem controversas que se estendem além dos argumentos éticos com relação a real eficiência desse método de ensino e pesquisa diante o avanço tecnológico-científico existente (MORALES, 2008; RODRIGUES, 2011).

Para os indivíduos envolvidos nas ações de proteção aos animais, torna-se dispensável a utilização destes em experimentação. É possível utilizar métodos alternativos para a realização de pesquisas, bem como para a prática de ensinoaprendizagem (MAGALHÃES, 2006; RODRIGUES, 2008). Dessa maneira, foi aprovada no Brasil em 2008 a Lei 11.794 (Lei Arouca), a fim de normatizar o uso de animais para procedimentos científicos, constituindo dessa maneira o ponta pé inicial para criação das Comissões de Ética para o Uso de Animais (CEUA), assim como a criação do Conselho Nacional de Controle de Experimentação Animal (CONCEA), responsáveis pelas discussões pertinentes à utilização de animais em laboratórios (BRASIL, 2008). Embora lentamente, discussões sob a legislação brasileira têm avançado naquilo que diz respeito à preocupação da regulamentação da utilização de animais em práticas didáticas ou científicas com base na Lei Arouca. Na verdade, a vigência da legislação para criação e utilização de animais voltadas ao ensino e a pesquisa impõe limites à prática, levando em consideração a proteção dos animais, preconizando o planejamento do experimento, onde acima de tudo visa utilizar o menor número possível de animais, evitar estresse, dor ou sofrimento desnecessários (GUIMARÃES, 2016).

Dentro desta perspectiva acadêmica, as recomendações que envolvem os cursos de graduação, entre os mais diferentes planos de ensino presentes no Projeto Pedagógico de Curso (PPC), são decorrentes das reformas educacionais que envolvem tanto o cenário nacional quanto internacional de instituições públicas e privadas. Neste contexto, práticas educacionais vêm sofrendo alterações gradativas que refletem nas adequações do cotidiano acadêmico, onde os PCNs sugerem um novo sentido aos mecanismos que envolvem o Ensino de Ciências. Isso coloca o docente apto a desenvolver habilidades e atitudes éticas, afim de explorar conhecimentos, restringindo a utilização de animais de experimentação no ensino, efetivando a produção de conteúdo e de material didático-pedagógico que atenda ao 
grau de detalhamento necessários quando comparados aos estudos in vivo (MACEDO, 2005; PAIXÃO; SCHRAMM, 2008; MARTINS FILHO, 2010; DRAKE, 2014; SCOTT; MOXHAM; RUTHERFORD, 2014; LOZANO, 2017).

\subsubsection{Embriões de aves como modelo de estudo}

Embora os embriões de aves sejam comumente empregados como modelo para estudos nas áreas de embriologia comparada e biologia do desenvolvimento, eles também têm sido usados como modelo para estudos de agentes tóxicos, já que são muito sensíveis à ação de agentes químicos (BRUNSTRÖM \& REUTERGÅRD, 1986; BRUNSTRÖM, 1988-1989; ENGWALL et al., 1994).

Os embriões de aves apresentam vantagens que se destacam pela facilidade de obtenção, facilidade na manipulação e monitoramento acerca das alterações que ocorrem ao longo do período de desenvolvimento da espécie. Outros aspectos relevantes considerados para a sua utilização são: os ovos são do tipo megalécito; apresentam membranas envoltórias extremamente resistentes; o tempo total de desenvolvimento é relativamente curto quando comparado com outras espécies domésticas; os indivíduos se desenvolvem na ausência do organismo materno e seu desenvolvimento é muito bem documentado (HAMBURGER \& HAMILTON, 1951; SCHOENWOLF, 1999). Tais características fazem do embrião de Gallus gallus um excelente modelo para o estudo da Biologia Tumoral, bem como modelo para estudo da angiogênese e transplante de tecidos. Para além disso, apresenta-se como modelo experimental fundamental na avaliação dos efeitos de agentes químicos tóxicos no desenvolvimento embrionário e, dependendo dos estágios avaliados, importantes comparações com mamíferos podem ser realizadas.

Em estudos laboratoriais torna-se necessário incubar os ovos de Gallus gallus por um período de 21 dias, a temperatura média é de 37 a $38^{\circ} \mathrm{C}$, oxigenação e umidade apropriadas para que a eclosão possa ocorrer aos 21 dias de incubação (GONZALES, 1994). A relação entre o aparecimento de estruturas embrionárias com o tempo de desenvolvimento pode ser organizada em estádios/dias (HAMBURGER e HAMILTON, 1951), o que possibilita acompanhar as rápidas transformações embrionárias que não poderiam ser registradas apenas em função do período em desenvolvimento. Assim, o conhecimento das etapas do desenvolvimento embrionário permite acompanhar a organização estrutural básica do embrião. 


\subsection{MÉTODOS COMPLEMENTARES DE ENSINO DA EMBRIOLOGIA}

O ensino das ciências morfológicas envolve um conjunto de fatores, descrição de fenômenos, bem como o entendimento concreto dos conceitos envolvidos ao longo do desenvolvimento, quando se trata da embriologia. Para Caldeira et al., (2009) muito dos conteúdos encontram-se restritos aos livros-texto, giz e lousa, mesmo que tenham aparecido ao longo dos tempos novas ferramentas para contemplar o processo de ensino-aprendizagem. Torna-se indispensável então que 0 docente adquira conhecimentos acerca das ferramentas inovadoras de ensino, na perspectiva de aprimorar sua práxis acadêmica (LIMA \& MOITA, 2011).

Segundo Gomes et al., (2017) vários são os meios complementares que podem ser utilizados em favor da escola, na formação técnico-científica e cidadã. Os autores destacaram ainda, a utilização de tecnologias por meio dos Blogs, e plataformas interativas, Wikis, aplicativos, jogos lúdicos, imagens em alta resolução, etc. De acordo com Heidger et al., (2002) a Universidade de lowa é pioneira na utilização de diversos recursos tecnológicos para complementar o ensino. Dentre os recursos utilizados destacam-se as videoaulas, CD-ROM, imagens panorâmicas interativas, websites e também banco de imagens. Na África do Sul, por exemplo, os docentes são adeptos aos meios midiáticos como fontes alternativas de ensino, para suprir as inconvenientes limitações e defasagem de aprendizagem dos alunos, principalmente dos alunos ingressantes (ACKERMANN, 2004).

As animações virtuais como ferramentas metodológicas para o ensino, são tipos de tecnologias que podem tornar as aulas de embriologia mais dinâmicas e interessantes. E o que aponta os resultados obtidos por Maia et al., (2017) nos quais a utilização de animações didáticas demonstram eficácia para a compreensão dos conteúdos abordados, quando utilizadas, como mecanismos de reforços às aulas expositivas e aos livros-texto. Com o objetivo de provocar maior interesse pelos conteúdos abordados em sala de aula, Mota (2010) relatou que quando os professores adotam novos métodos de ensino, estão adotando consequentemente um novo suporte pedagógico, permitindo uma maior sintonia do processo de ensinoaprendizagem com o contexto da modernidade.

Montanari (2017) ao criar um ambiente virtual por meio do programa Adobe Dreamweaver denominado auladeembrio, para ser utilizado na disciplina de 
embriologia do curso de Ciências Biológicas da UFRGS, como apoio didáticopedagógico às aulas presenciais e no estudo extraclasse, verificou, o acesso ao ambiente virtual para o estudo da disciplina, bem como sua contribuição para a aprendizagem dos alunos. A plataforma em sua constituição estrutural apresentava fotodocumentações macroscópicas ou obtidas mediante microscopia, tanto de luz quanto eletrônica, desenhos esquemáticos (realizados com o Adobe Illustrator), mapas conceituais (criados com o CmapTools) e exercícios.

O software intitulado "Embriologia Clínica Humana" desenvolvido por Moraes (2005) era em sua constituição provido de fotodocumentações digitais tanto macro quanto microscópicas de embriões, fetos e recém-nascidos submetidos à autópsia (MORAES et al., 2004). Ainda compunham o material histórias clínicas, filmes, ilustrações, animações e textos (MORAES \& PEREIRA, 2010) os quais foram utilizados no ensino da embriologia humana, como recursos pedagógicos da prática laboratorial. Em 2007, Duarte, utilizou as premissas de integração básico-clínica e ferramentas de e-learning ao conceito de avaliações formativas por meio do desenvolvimento do software "Quizzes em Embriologia Humana". A proposta foi fornecer assistência aos alunos para que avaliassem seus conhecimentos próprios e compreendessem, por meio da prática, suas habilidades, proporcionando uma experiência de aprendizagem mais ativa e fornecendo aos alunos mecanismos de resposta (feedback) enquanto sua aprendizagem estivesse ocorrendo (ROLFE \& MCPHERSON, 1995; HUDSON \& BRISTOW, 2006).

A utilização das ferramentas do e-learning no processo de ensinoaprendizagem tornou as atividades curriculares bem-sucedidas, ao menos do ponto de vista de satisfação, tanto dos discentes quanto dos docentes. A forma como esse material havia sido utilizado, até então, pouco alterava a estrutura do ambiente em sala de aula, uma vez que o foco principal era dado na percepção do usuário ao interagir com o material produzido durante atividades extraclasses, periodicamente agendadas (JUSTINO, 2013).

O desenvolvimento de modelos didáticos que ilustram o processo embrionário, compatíveis com o ensino da embriologia veterinária, permite ao alunado uma visão diferenciada do processo embriológico, facilitando a compreensão do conteúdo (FORMENTIN et al., 2020). Comumente utilizado nas práticas de ensino, a massa de "biscuit" é um grande aliado para o desenvolvimento de materiais didáticos. Formentin et al., (2020) utilizou esta massa incolor e tinta de tecido para o desenvolvimento de 
nove modelos que abrangeram os processos iniciais da clivagem, estendendo-se até o processo de alongamento do blastocisto. Três dos nove modelos representaram a clivagem inicial do zigoto, embriões no processo de segmentação contendo duas e quatro células; um modelo foi representativo da fase de mórula; três da fase de blastocisto e formação do saco vitelínico. Tais modelos acerca da embriogênese eram utilizados juntamente com as aulas teóricas e práticas ao longo da abordagem do conteúdo. Os autores destacaram ainda que o paralelo do desempenho acadêmico concomitante à utilização de modelos didáticos, apresentou-se como um recurso acessível e de baixo custo, bem como um grande aliado na práxis educacional.

Os modelos tridimensionais são utilizados na prática de ensino. Na abordagem do conteúdo acerca da embriologia do sistema nervoso central, a literatura demonstra dados analisados antes e após a utilização desses recursos. Ao comparar os resultados foi possível notar que não há uma grande diferença significativa na aprendizagem dos estudantes. De acordo com Moraes \& Muniz (2018) o percentual de aprendizagem é de 0,2337, média de 4,14 de acertos versus 3,86 do grupo controle. Entretanto, os autores na utilização de diferentes tipos de tecnologias modernas como recursos didáticos, de maneira que estes ofereçam aos alunos modelos pedagógicos ricos em detalhes, mantem a instituição atualizada naquilo que se refere às inovações em tecnologia.

A utilização da dinâmica mediante modelos 3D não é mais eficaz do que o ensino dito tradicional na embriologia. Entretanto, o feedback dos alunos referentes à dinâmica, apresentou-se extremamente positivo e de suma importância na abordagem do conteúdo (MORAES \& MUNIZ, 2018). Para Silveira \& Ideriha (2013) a utilização dos modelos tridimensionais apresenta-se como parte compensatória às diversas limitações das figuras bidimensionais encontradas nos livros-texto, bem como um recurso que supria a falta de materiais biológicos disponíveis para abordagem do conteúdo, constituindo de fato uma estratégia de inovação no ensino. Deste modo, estas auxiliaram os estudantes na observação mais concisa do desenvolvimento embrionário, sem causar frustações no aprendizado, uma vez que várias estruturas presentes ao longo do desenvolvimento são difíceis de ser observadas.

Para os dias atuais Rojas et al., (2020) apresenta o microscópio virtual como um novo modelo de ensino referente ao desenvolvimento embrionário e fetal. Tal metodologia apresenta-se como uma fonte de recurso afim de suprir a ausência das aulas presenciais em tempos de pandemia (COVID-19). O autor por meio da 
ferramenta tecnológica apresenta fotografias de lâminas histológicas correspondente ao desenvolvimento embrionário de Gallus gallus domesticus (40 horas de incubação), feitas por cortes seriados digitalizados mediante observação pelo microscópio NanoZoomer XR série C12000 (Hamamatsu Phtonics, Hamamatsu, Japão). Rojas apresenta ainda imagens ilustrativas de alta resolução referentes ao desenvolvimento renal em humanos, comparando o mesmo ao desenvolvimento renal de aves (Gallus gallus domesticus). Ambos os recursos se encontram hospedados em plataforma virtual que pertence à Universidade do Chile.

\subsection{ENSINO A DISTÂNCIA (EAD)}

\subsubsection{Conceitos}

O ensino a distância (EaD) é conceituado de forma simples, no qual os alunos e professores estão separados pela distância e algumas vezes também pelo tempo (MOORE \& KEARSLEY, 1996, p.1). Os autores ainda definiram seis elementos fundamentais como características básicas do EaD: a separação entre discente e docente, a influência de uma organização educacional (planejamento e preparação dos materiais de aprendizado), a utilização de meios técnicos-mídia, as providências para comunicação em duas vias e por fim, e a quase permanência da ausência de grupos durante o processo de aprendizagem (KEEGAN, 1990).

Pautado em métodos direcionados à construção de um cidadão contemporâneo, participante e utilizador de ferramentas de assimilação, de interferência e de participação realista, estudos demonstram a necessidade da adequação de novas metodologias, bem como do aperfeiçoamento da qualidade do ensino, na qual diferentemente dos cursos de graduação em Medicina Humana, nas Ciências Agrárias e Biológicas, por exemplo, metodologias complementares e/ou alternativas que auxiliam no aprendizado do aluno, são pouco existentes. Deste modo, opcionalmente brasileiros passaram a desenvolver protótipos diversos popularizandoos entre a comunidade acadêmica nas mais diferentes formas e condições (BRASIL, 2000; COSTA NETO; MARTINS FILHO, 2017).

Neste contexto, de todos os elementos básicos discutidos, o único que não se aplica em modelos de ensino à distância mediada via sistema computacional, é a quase permanência da ausência de grupos durante o processo de aprendizagem. 
Assim, se abre a possibilidade de formação de redes de aprendizagem, com foco na colaboração entre os participantes (HOLMBERG, 2003; HARASIN, 2005).

Aretio (1996) defendeu que, a relação do aprendiz é mais ligada com a organização. Sua estrutura permite no modo presencial intimidade da relação docente-discente. Por vez, é fundamental que o ensino a distância seja planejado de forma cuidadosa, com a implantação de uma estrutura adequada para atender à necessidade do alunado evitando que os mesmos se sintam isolados no processo.

\subsubsection{Evolução teórica}

Desde a metade do século XVIII o EaD surgiu pela necessidade de atender alunos que não podiam comparecer à escola regular, mas, que necessitariam se preparar para o mundo industrial. Assim, na metade do século XVIII até a década de 70 no século $X X$, ocorreu a origem a primeira geração de ensino a distância, tendo como característica e recurso da época a mídia impressa (SAMMONS, 2003; PETERS, 2003).

Neste contexto, foi e é possível observar um rápido desenvolvimento do ensino a distância graças à evolução dos meios de comunicação em massa, ou seja, notadamente o rádio, televisão, seguido dos recursos de vídeos e de fitas cassetes. Mais tarde, da implantação de centros de estudos, iniciando a segunda geração da EaD (SAMMONS, 2003; PETERS, 2004). A introdução destas novas tecnologias possibilitou que houvesse uma rápida expansão desta modalidade de ensino. Foi a partir daí que surgiram novas possibilidades para que a população em massa tivesse acesso a novos conhecimentos e saberes. O termo ensino a distância passou a ser mais utilizado a partir da década de 80 e o reconhecimento da utilização desse termo pode ser atestado quando, em 1982, o International Council for Correspondence Education (ICEE) decidiu mudar seu nome para Internacional Council for Distance Education (ICDE), fato este que revelou a origem do termo $\mathrm{EaD}$ em questão (HOLMBERG, 1995).

Seguindo os avanços dos estudos nesta área, finalmente a Teoria da Interação e da Comunicação proposta por Holmberg (1995-2003) defende que um curso ministrado a distância deve utilizar um estilo de conversação com o aluno, criando um senso de pertencimento e cooperação didático-pedagógica que interfira positivamente em sua motivação. 
Já a terceira geração de $\mathrm{EaD}$ datada dos anos 90 , coloca em cena o ensino online, mediado pelo sistema computacional, que proporcionou ainda mais a autonomia do discente. Assim, com as novas mídias, mesmo à distância, houve uma maior interação entre professor-aluno, e até mesmo com a forma de organização dos alunos com ensino, proporcionando meios capazes de estimular o envolvimento e a comunicação entre os participantes, seja por intermédio de ferramentas em tempo real (síncronas) ou remota (assíncronas) (FUKS, 2000).

\subsubsection{Tecnologia e comunicação}

O impacto das novas tecnologias de ensino na sociedade e na vida cotidiana e acadêmica é cada vez mais evidente, e, apenas passa despercebido nos dias atuais para uns poucos renitentes, que esperam assim fugir aos temores do desconhecido desta nova aventura. Os recursos tecnológicos já disponíveis, desencadeiam novas formas de ler, pensar, escrever e agir. Uma vez que o processo educativo sob este prisma pressupõe uma nova forma de possibilitar a construção e a elaboração do conhecimento, diferente do tradicional, por meio de características específicas das novas tecnologias (BAHLIS, 2005).

Definido como um "processo de ensino-aprendizagem mediado por tecnologias, onde os professores e alunos estão separados espacialmente e/ou temporalmente" o ensino a distância possibilita ensinar e aprender com programas que incluem o melhor da educação presencial, com as novas formas de comunicação virtual. Em alguns momentos é necessário encontros físicos, no início e no final de um módulo ou curso. Em outros, aprende-se mais estando cada um no seu espaço de rotina, mas de maneira a manter-se conectados com os demais colegas e professores. Isso ocorre para o intercâmbio constante, tornando real o conceito de ensino permanente, auxiliando a comunidade científica e acadêmica a se equilibrarem, conforme suas necessidades e habilidades, incluindo grupos presenciais e virtuais, de forma a ter um rápido desenvolvimento na aprendizagem (MORAN, 2007).

Deste modo, o processo de comunicação entre aluno-professor pode ocorrer tanto em tempo real quanto de forma remota. A comunicação em tempo real é caracterizada por permitir uma comunicação simultânea entre os autores envolvidos, incentivando e motivando a interação entre eles. Já a comunicação remota, não requer participação simultânea de alunos e professores. Isso faz com que os primeiros 
possam escolher seu próprio ritmo de aprendizagem, proporcionando-lhes maior flexibilidade e tempo para reflexão do aluno sobre ideias, além do incremento da checagem sobre anotações e pesquisas.

Acredita-se que o espaço e o tipo de comunicação requerida pelo novo paradigma de ensino, ocorra entre a universidade e a escola, ultrapassando o modelo criado pelos meios de comunicação de massa, olhando com toda atenção para os novos meios interativos e multimidiáticos, propondo mudanças satisfatórias para os alunos e para a sociedade. Mas, a realidade é que não existe uma tecnologia ou mídia definitiva em ensino a distância. São os fatores econômicos, pedagógicos e culturais, entre outros, que definirão o(s) método(s) pelo(s) qual(is) o qual o curso irá ensinar, com relação as mídias/tecnologias.

\subsubsection{Ensino superior e o ensino a distância (EaD)}

O Ensino a distância tem recebido diversos conceitos com seus respectivos enfoques. No inglês - Distance Education (DICIONÁRIO, 2003), o EaD denominado a partir de agora, é enfatizado, ora como fator de distância geográfica entre professor e alunos, ora, quanto ao uso de tecnologias de informação e comunicação. Isso ocorre devido à crescente demanda apresentada nas instituições de ensino e no mercado de trabalho nos dias atuais. Deste modo, o ensino a distância tem se mostrado como um método alternativo, pois tem se consolidado com o tempo, demostrando as suas diversas vantagens que vão desde a flexibilidade de aprendizagem, até a possibilidade de ensino mais personalizado respeitando o ritmo e valorizando a autonomia de cada indivíduo, extrapolando os limites de tempo e espaço. Já não faz sentido pensar que docentes e discentes devem obrigatoriamente estar no mesmo horário e no mesmo local para que o conhecimento seja construído, havendo a necessidade de reflexão sobre concepção clássica de ensino-aprendizagem e transformação social (BALDO, 2008; BISCONCIM, 2018).

Sendo perfilhado em diversas universidades tais como nas Universidades da Califórnia, MIT, Cornell, Harvard, Michigan, Indiana, Stanford, Oxford e Cambridge situadas nos mais diversos países, o EaD traz como perspectiva dissipar as barreiras que impedem o acesso à educação, de maneira a proporcionar um ensino de qualidade e oferecer ampla oportunidades àqueles que, por diversos motivos, não deram continuidade aos estudos (CORNACHIONE; SILVA, 2000). 
Pensando no proposito educacional, o ensino a distância tornou-se estratégia eletrônica de autoinstrução, a qual traz componentes que promovem possibilidades de retenção do aprendizado, gerando um maior conhecimento de forma interativa, não se limitando as respostas prontas e não encerrando no próprio sistema (NEVES, 2000). O programa, o curso, a disciplina a distância dependendo do padrão de interatividade poderão ser ajustados às propostas específicas, considerando o perfil do aluno e/ou grupo com o qual se pretende interatuar. Os cursos que fazem a utilização deste método de ensino podem ser estruturados de maneira à facilitar a comunicação, interação e a avaliação, da mesma forma ou até melhor do que os que ocorrem em ambientes presenciais de ensino, onde o aluno não observe a educação como um processo passivo e apenas receptivo de conteúdos (CARR; FARLEY, 2003).

Embora a concepção de uma proposta pedagógica possa estar embasada por tendências de demanda com relação a exploração cognitivista de aprendizagem e inteligência virtual, a aproximação desse pressuposto pode e deve formar métodos referenciais, dando sustentação ao trabalho, de forma a analisar conceitos de integração e de colaboração na EaD (BEHRENS, 2002, p.88).

\subsubsection{Integração e colaboração no Ensino a distância (EaD)}

Expressa pela política e pelo planejamento educacional do país, a Lei de Diretrizes e Bases da Educação Nacional Brasileira, define o ensino a distância como "uma forma de ensino que proporciona a autoaprendizagem sendo mediada por diversos recursos didáticos integrados, apresentados em diferentes suportes de informação, podendo ser utilizados tanto isolada quanto combinada, e veiculados pelos mais diversos meios de comunicação" (BRASIL, 1996).

Em Piaget (LA TAILLE, 1992) encontramos que há, na educação, um lugar de interação social, na perspectiva de uma formação inovadora, exigida em todas as áreas do conhecimento. Com isso, faz-se necessário trabalhos coletivos, métodos complementares, discussão em grupo, cooperação, contribuição e parcerias. Vale ressaltar a partir disso que, as instituições que oferecerem uma prática pedagógica que instigue e propicie o aprendizado dos alunos via a essa nova proposição na modalidade a distância, estarão na vanguarda quanto à aprendizagem dos seus alunos tanto para o mercado de trabalho quanto para a vida (BEHRENS, 2002, p.76). 
Deste modo, é necessário que ocorra o abandono de uma escola burocrática, hierárquica, organizada por especialidades visando a construção de uma escola aberta, contendo mecanismos de participação e descentralização flexíveis, que obtenham regras de controle discutidas de forma integrada pela comunidade (MORAES apud BEHRENS, 2002). Pensando num paradigma emergente, essa opção metodológica assenta-se em ações diferenciadas, como saber pensar, aprender a aprender, aprender a conviver, aprender a ser, aprender a fazer, aprender a conhecer e a produzir conhecimentos próprios (BEHRENS, 2002, p.128).

Com a Lei de Diretrizes e Bases da Educação (LDB), pelas Portarias no 2.253/2001, no 4.059/2004, no 1.134/2016 e indiretamente pelos Planos Nacionais de Educação - PNE (2001-2010 e 2014-2024), as instituições de Ensino Superior podem inserir, na preparação pedagógica e curricular de seus cursos reconhecidos pelo Ministério da Educação e Cultura (MEC), a oferta de disciplinas de modalidade semipresencial em seus currículos, autorizando também a substituição de até $20 \%$ (vinte por cento) da carga horária total do curso, para que sejam ofertadas disciplinas parciais ou integrais na modalidade a distância (BRASIL, 2016). Para Teixeira et al., (2018) existe uma convergência entre o fenômeno presencial-virtual como política pública do governo no atendimento às expectativas de ampliação de oferta no Ensino Superior brasileiro.

Quando se trata da inserção do ensino a distância nas áreas das Ciências Biológicas, Ciências Agrárias, e na Medicina Veterinária tal inserção é vista como fenômeno desafiador uma vez que as normas determinam que as disciplinas curriculares de graduação e seus conteúdos teórico-práticos devam ser ministrados exclusivamente sob a modalidade presencial (CFMV, 2016). No entanto, em 2019, o MEC divulgou a aprovação de quatro cursos de Medicina Veterinária na modalidade EaD no Brasil. Mas, o Conselho Federal de Medicina Veterinária logo de imediato vetou o registro profissional de médicos veterinários formados na referida modalidade (DOU, 2019).

Contudo, as instituições de âmbito nacional e internacional estão cada vez mais desenvolvendo pesquisas na perspectiva de incluir a aprendizagem on-line em seus currículos e que estes têm se mostrado tão eficientes, quanto os programas de ensino tradicional presencial (BERNADO, 2004). A ideia em discussão sobre o ensino a distância é que o aluno se coloque como protagonista, e como um dos principais responsáveis pelo processo educacional em um ambiente de diálogo. Toda esta 
perspectiva de oferta no ensino é de interesse de instituições públicas e, principalmente, das instituições privadas. Neste contexto, ocorre o processo de virtualização da sala de aula, com a popularização do uso de ambientes virtuais de aprendizagem (TEIXEIRA; FERREIRA; MICHELS, 2018).

Embora o ensino remoto (ou a distância) tenha como instrumento o transporte ou a transferência de informações que proporcionam um crescimento educacional em suas mais diversas áreas, isso possibilita atingir lugares de difícil acesso, onde a educação presencial é deficitária ou até mesmo inexistente, gerando um grande impacto social e econômico para a população (NASCIMENTO, 2008). Para Garcia \& Carvalho Junior (2015) o ensino a distância pode ser visto como um instrumento facilitador que ameniza ou até mesmo extingui os problemas recorrentes da educação no Brasil, podendo driblar obstáculos, permitindo o acesso educacional às regiões geograficamente isoladas do país, ou mesmo à locais onde falta estrutura laboratorial, possibilitando assim a educação continuada.

\subsubsection{O EaD como motor da educação em tempos de COVID-19}

As aulas a distância, segundo a Associação Brasileira de Mantenedoras de Ensino Superior (ABMES) apresentou crescimento significativo por causa do novo corona vírus causador da doença COVID-19. Em razão disso, o Ministério da Educação (MEC) publicou no dia 18 de março de 2020 a portaria $n^{\circ}$ 343, que autorizou "em caráter excepcional" a substituição das aulas presenciais por aulas na modalidade a distância, portaria essa que se estende até dezembro de 2020 , devido ao avanço da pandemia. A novidade reforçou a importância da modalidade EaD para aqueles que almejam em se qualificar no período do isolamento, bem como a viabilidade da qualificação a distância mesmo em "tempos normais".

Assim, diante da mudança ocorrida, estudantes, escolas, faculdades e universidades se desdobraram para se adaptar à rotina e às aulas voltadas para a nova realidade, a fim de não comprometer o cronograma escolar no período de distanciamento social. Entretanto, muitas instituições não se adaptaram ao novo sistema por falta de recursos. Com esse cenário, a perspectiva é que os estudantes tivessem acesso às aulas mesmo que de forma remota, e que essas fossem contempladas com apresentações explicativas de slides, respostas de dúvidas por e- 
mail utilizando computadores e/ou similares, a fim de complementar os demais dias letivos exigidos por lei (ABMES, 2020).

Para tanto, a mestra em Educação e Contemporaneidade pela Universidade do Estado da Bahia (UNEB), Cíntia Dantas, 31, do curso de Pedagogia EaD, da UNINASSAU, relatou que um dos maiores desafios de quem estuda de forma remota é manter a disciplina. "É preciso ficar atento ao comportamento pessoal para não cair na armadilha de se atrapalhar com os estudos. Tem que ter muita disciplina porque o fato de ter o tempo que quiser para fazer as atividades, às vezes, atrapalha porque você vai deixando para a última hora." 


\section{MATERIAL E MÉTODO}

O presente estudo realizado na Faculdade de Medicina Veterinária e Zootecnia (FMVZ), da Universidade de São Paulo (USP), Laboratório de Anatomia Macro, Microscópica e do Desenvolvimento e Laboratório de Ornitopatologia, foi aprovado pela Comissão de Ética no Uso de Animais (CEUAVet) desta mesma instituição, sob

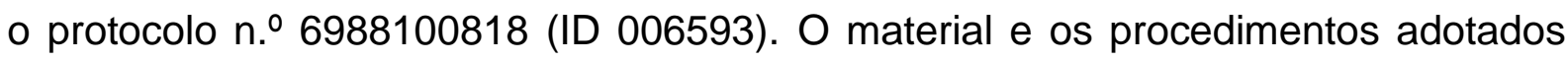
para a realização deste trabalho estão divididos em:

\subsection{OBTENÇÃO DOS ESPÉCIMES}

A obtenção dos ovos fertilizados incubados em estufa úmida com temperatura de $37^{\circ} \mathrm{C}$ foram doados pelo Laboratório de Ornitopatologia e transportados para 0 Laboratório de Anatomia Macro, Microscópica e do Desenvolvimento da FMVZ-USP (ANEXO A. p, 260).

\subsection{DADOS BIOMÉTRICOS E CONSERVAÇÃO DOS ESPÉCIMES}

A classificação utilizando os espécimes de aves (Gallus gallus domesticus) ocorreu seguindo a metodologia preconizada dos estágios (ou idade) proposto por Hamburger e Hamilton (1951).

Os espécimes foram fotodocumentados utilizando uma câmera fotográfica Canon EOS 60D, fixados em solução de formaldeído $10 \%$ e paraformaldeído $4 \%$ em tampão fosfato $0,1 \mathrm{M} \mathrm{pH} \mathrm{7,4} \mathrm{e} \mathrm{estocados} \mathrm{para} \mathrm{posterior} \mathrm{descrição} \mathrm{dos} \mathrm{resultados.}$

\subsection{ANÁLISE MACROSCÓPICA}

Os embriões após a coleta dos dados biométricos, classificação e fixação, com auxílio de lupa seguiram-se para descrição morfológica mediante observação direta das estruturas que juntas constituem o corpo do animal.

A nomenclatura utilizada será referida conforme a Nomina Embryologica Veterinária (2017), Nomina Anatomica Veterinaria (2017) e a Handbook of Avian Anatomy: Nomina Anatomica Avium (1993). 


\subsection{DESENVOLVIMENTO DO MATERIAL DIDÁTICO}

\subsubsection{Organização do módulo e seleção do conteúdo}

A revisão de literatura para elaboração de todo o material didático teve início com a seleção de achados clássicos da área tanto de embriologia comparada quanto de anatomia, que estão relacionados ao Ensino Superior e que tem a disciplina de embriologia animal como parte da grade curricular, como é o caso, por exemplo, dos cursos de Ciências Biológicas e Medicina Veterinária. Pesquisa-se a respeito das estratégias ativas de ensino-aprendizagem incluindo a virtualização da sala de aula, bem como a inclusão sugestiva de livros/e-books de referência na área, como também trabalhos científicos publicados em periódicos.

Neste sentido, os conteúdos eleitos e subdivididos estendem-se de acordo com as diferentes fases transcorridas do desenvolvimento embrionário entre a fecundação e o nascimento, somando um total de nove diferentes aulas que pertencem ao Módulo I (Desenvolvimento embrionário: conceitos gerais e aspectos morfológicos). Na Figura 1 é possível observar a organização pedagógica referente a cada aula/capítulo que foram transformados em Portable Document Format (PDF), traduzido para o português como formato de documento portável. 
Figura 1 - Fluxograma referente a organização pedagógica dos capítulos que contemplam o módulo de aulas I, seguindo a cronologia de ocorrência dos eventos envolvidos no desenvolvimento embrionário.

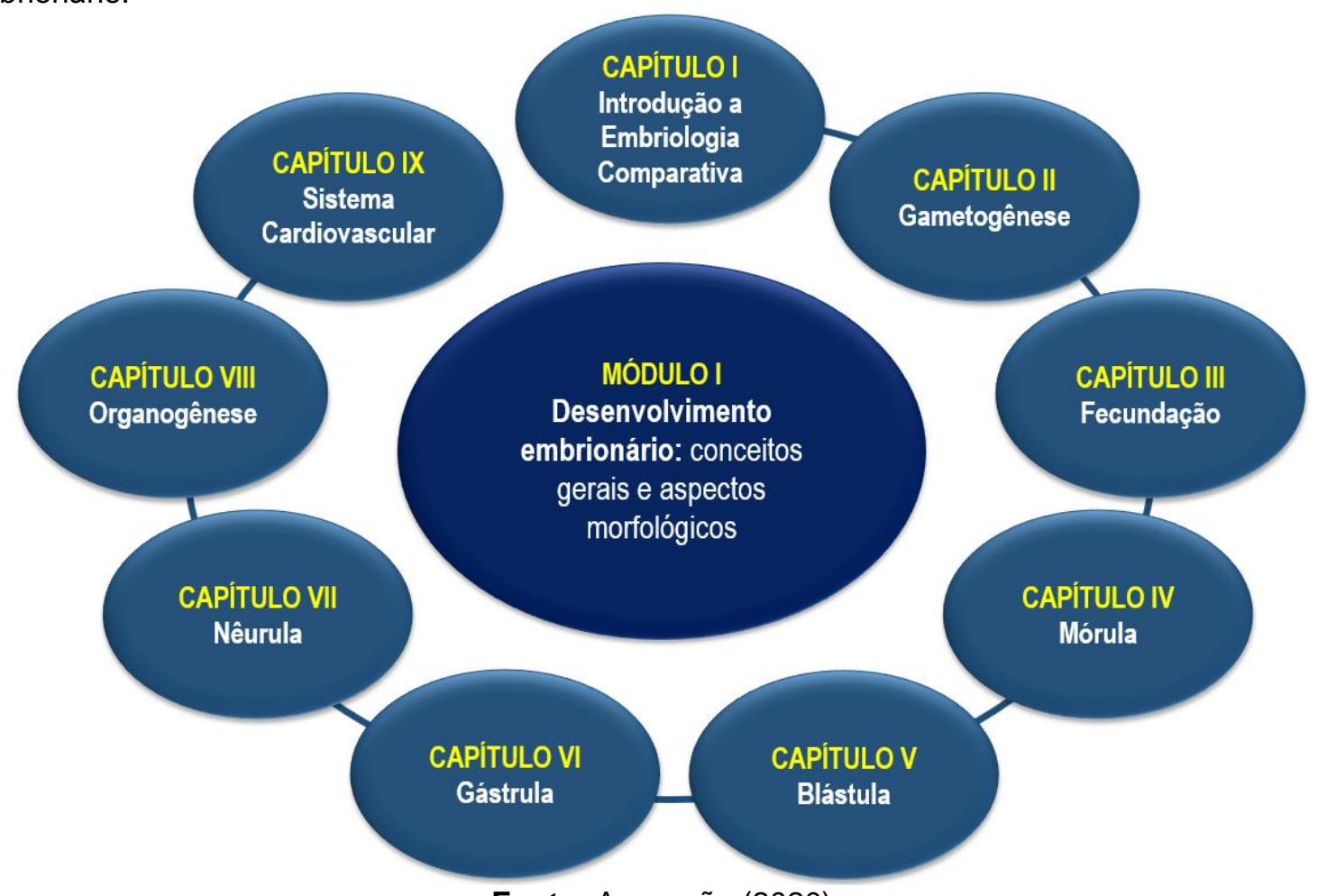

Fonte: Assunção (2020).

\subsubsection{Transposição didática das imagens para o desenvolvimento do atlas macroscópico intitulado "Embriologia veterinária"}

As imagens capturadas acerca do desenvolvimento embrionário no que se refere a análise mesoscopica dos espécimes, foram submetidas a uma transposição didática. Para isso, utilizou-se o programa Adobe Photoshop e uma mesa digitalizadora Wacom Intuos tanto para o início quanto para a finalização da imagem. Com o programa Photoshop, foi feito uma camada como esboço inicial das imagens. Utilizando pincéis digitais (brushes) e ferramentas de seleção acertaram-se as proporções das figuras para que as mesmas tomassem proporções viáveis e com alta resolução (4K).

Após o esboço realizado na camada principal, criou-se uma segunda camada no programa, apenas para aplicar cores específicas à imagem. Essa nova camada foi então posicionada em cima da anterior. Utilizando a ferramenta de seleção do Photoshop, a área colorida tornou-se estruturada. Com um "balde" de tinta, clicou-se na área selecionada aplicando a cor desejada. Uma vez que com a cor base aplicada, a camada em que se pigmentou foi isolada, logo em seguida a informação daquela 
camada específica tornou-se "protegida". Tal método possibilitou a coloração sem evasão do objeto. Utilizando a ferramenta "pincel", adicionou-se as sombras e luzes necessárias para que as figuras ganhassem um aspecto $3 \mathrm{D}$, ou seja, a tridimensionalidade.

Já com o acesso ao cubo de cores no programa, foi possível escolher qual cor utilizaria, e, portanto, impregnou-se na coloração do objeto. Na etapa final do desenvolvimento da imagem ilustrativa, utilizou-se um pincel com tamanho reduzido, detalhes foram adicionados para dinamização e composição da imagem. Por fim, com

a composição feita e imagem finalizada, o arquivo foi salvo em formato JPEG (Joint Photographics Experts Group) ou PNG (Portable Network Graphics) para que comportasse a alta definição da imagem transposta.

\subsubsection{Videoaulas e podcasts}

As gravações das aulas referente a cada capítulo do módulo I desenvolvidas até o presente momento, ocorreu nos estúdios do Departamento de Cinema, Rádio e Televisão (CRT) da Escola de Comunicação e Artes (ECA), da Universidade de São Paulo (USP).

Os vídeos em um tamanho de aproximadamente $5 \mathrm{gb}$, foram renderizados por meio do Programa Sony Vegas o qual manteve a qualidade do vídeo em alta definição. No mesmo programa, as legendas em 3 idiomas (Português, inglês e espanhol) foram inseridas, áudio melhorado e efeitos de transição foram adicionados.

Após a renderização dos vídeos no Sony Vegas, foram transferidos e adicionados ao Programa Adobe Affter Effects, conhecido como um dos melhores programas para efeitos visuais. Nele foi possível caracterizar cada aula com as logomarcas institucionais, termos específicos do conteúdo em forma de palavraschaves em destaque ao longo do vídeo, inserção de vinheta de fundo e descrição da equipe de produção, finalizando o processo de edição.

A ferramenta utilizada para conversão das vídeo aulas em podcasts (que se baseia no uso de áudios), ocorreu pela base do Programa Freemake, gerando os arquivos no formato MP4.

\subsection{ESTRUTURAÇÃO DO AMBIENTE VIRTUAL}


A base de inserção de todo o material didático-pedagógico elaborado é a Plataforma EAD Guru, a plataforma foi escolhida pela acessibilidade, baixo custo e pela disponibilidade de recursos como aulas e arquivos ilimitados, hospedagem de vídeos de forma segura e em alta definição (4K), acesso por qualquer dispositivo (computador, smartphone ou tablet), questionários, estatísticas, domínio próprio, Ecommerce, suporte, fórum de dúvidas para interação entre professor e aluno, certificados, depoimentos e proteção do conteúdo.

$\mathrm{Na}$ aba meus cursos, serão oferecidos nove diferentes capítulos/aulas que pertencem ao Módulo I (Desenvolvimento embrionário: conceitos gerais e aspectos morfológicos). O módulo, por sua vez, compreende diferentes passos para o percurso formativo, a saber: avaliação inicial, apresentação institucional e glossário, vídeo aulas e podcasts, capítulos em PDF, atividades complementares, atlas figurativo da morfologia ultra estrutural, artigos publicados em periódicos, avaliação final, pesquisa de satisfação e ao final um certificado de conclusão das atividades. 


\section{RESULTADOS}

Os resultados apresentados a seguir se referem às obtenções das características macroscópicas dos espécimes Gallus gallus domesticus, bem como o desenvolvimento de materiais midiáticos que contemplam o processo de ensinoaprendizagem da embriologia veterinária, estes encontram-se inseridos na base da plataforma EaD Guru.

\subsection{ANÁLISE DOS ESPÉCIMES}

As características embriológicas citadas, bem como os estágios de ocorrência são baseados na literatura e por meio de observação das amostras biológicas coletadas. Algumas citações com relação aos resultados não são verdadeiramente externas, mas sua presença ou ausência pode ser determinada de acordo com a ocorrência e progressão dos estágios embrionários. A nomenclatura utilizada segue os preceitos adotados pela International Anatomical Nomenclature Commission e adotados pela International Anatomical Congress in Leningrad já mencionados.

Para tanto, os resultados foram obtidos e estão apresentados conforme as seguintes análises:

\subsubsection{Análise macroscópica}

Foram analisados no estudo 63 espécimes de Gallus gallus domesticus. Destes apenas 21 foram selecionados para a descrição dos resultados. O quadro 1 apresenta a idade e o peso corporal dos espécimes de Gallus gallus domesticus. 
Quadro 1. Idade (dias) e peso corporal (g) dos espécimes de Gallus gallus domesticus.

\begin{tabular}{|c|c|}
\hline $\begin{array}{l}\text { IDADE } \\
\text { (dias) }\end{array}$ & $\begin{array}{c}\text { PESO } \\
\text { (gramas) }\end{array}$ \\
\hline 01 & $\mathrm{~N} / \mathrm{A}$ \\
\hline 02 & $\mathrm{~N} / \mathrm{A}$ \\
\hline 03 & $\mathrm{~N} / \mathrm{A}$ \\
\hline 04 & 0,00 \\
\hline 05 & 0,04 \\
\hline 06 & 0,15 \\
\hline 07 & 0,21 \\
\hline 08 & 0,83 \\
\hline 09 & 1,44 \\
\hline 10 & 1,64 \\
\hline 11 & 2,86 \\
\hline 12 & 3,86 \\
\hline 13 & 6,12 \\
\hline 14 & 8,27 \\
\hline 15 & 12,27 \\
\hline 16 & 14,21 \\
\hline 17 & 16,26 \\
\hline 18 & 18,30 \\
\hline 19 & 21,10 \\
\hline 20 & 23,45 \\
\hline 21 & 24,40 \\
\hline
\end{tabular}

Fonte: Assunção (2019).

Os embriões de aves (Gallus gallus domesticus), de 1 a 3 dias, respectivamente, com características morfológicas macroscópicas visíveis como: um "escudo embrionário" observado devido ao acúmulo de células na cavidade germinativa, esta incluía, uma dobra definitiva da blastoderme marcando a extremidade anterior do concepto, apresentam-se ainda no interior do ovo o vitelo (ou gema), o disco germinativo, "ilhas" de sangue envolvidas na circulação vitelínica, formação do coração e o desenvolvimento das funções cardíaca, bem como a formação do embrião propriamente dito (Figura 2). 
Figura 2 - Fotodocumentação dos embriões de aves (Gallus gallus domesticus) com intervalo de 1 a 3 dias do desenvolvimento. (A) 1 dia - (v) vitelo; (is) "ilhas" de sangue; (dg) disco germinativo. (B) 2 dias - (e) embrião. (C) 3 dias - (vs) vasos sanguíneos. Barras referentes a $2 \mathrm{~cm}$.

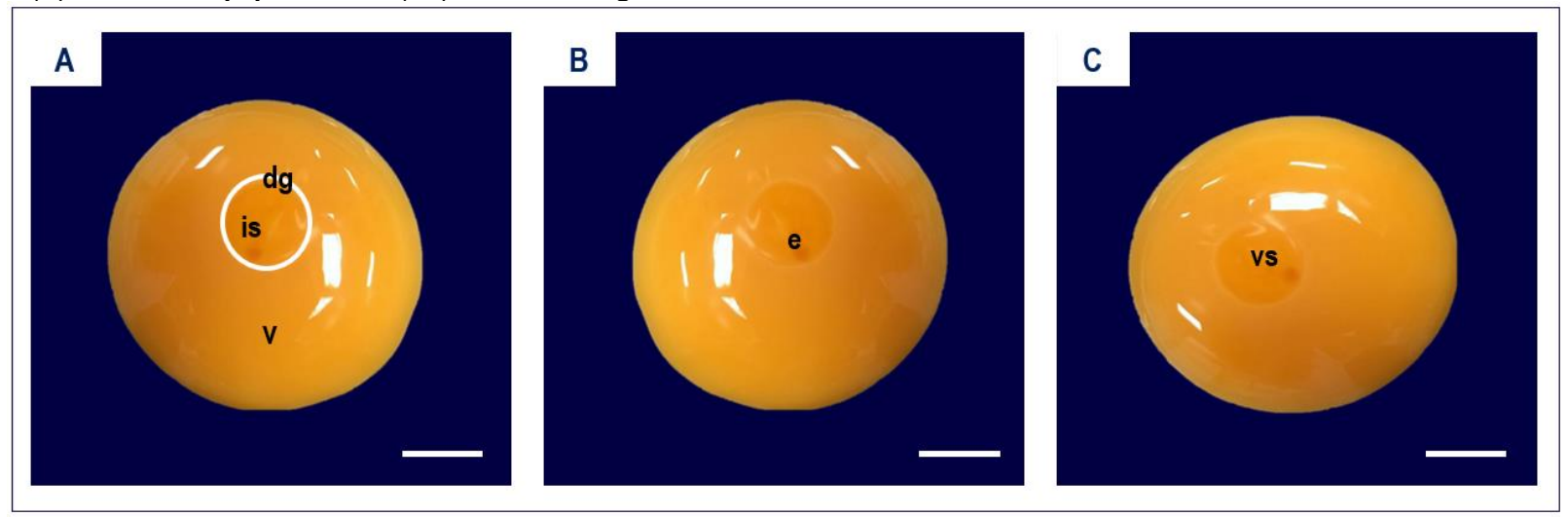

Fonte: Assunção (2019).

Os embriões que compreendem o intervalo de 4 a 6 dias, com peso corporal entre $0,00 \mathrm{~g}$ a $0,15 \mathrm{~g}$, respectivamente, mostravam-se com as seguintes características estruturais: curvaturas tanto encefálicas quanto cervical, arcos faríngeos, início da formação da língua, proeminência cardíaca, formação da cauda, bem como seu alongamento. Os membros torácicos e pélvicos encontravam-se em estágio de desenvolvimento (relacionado ao tamanho) em grau igualitário, e encontravam-se em processo de alongamento. Observava-se também a proeminência hepática, a formação da vesícula óptica e a retina já pigmentada. As vesículas encefálicas entravam mais tarde em processo de diferenciação. Foi notório o desenvolvimento dos anexos de natureza córnea tal como a formação da ranfoteca (ou bico) (Figura 3).

Figura 3 - Fotodocumentação, vista lateral esquerda, dos embriões de aves (Gallus gallus domesticus) com intervalo de 4 a 6 dias do desenvolvimento. (D) 4 dias - (ce) curvatura encefálica; (ab) arcos branquiais; (I) língua em desenvolvimento; (cc) curvatura cervical; (pc) proeminência cardíaca; (c) cauda. (E) 5 dias - (ve) vesícula encefálica; (vo) vesícula óptica; (bmt) broto do membro torácico; (ph) prominência hepática; (bmp) broto do membro pélvico; (ca) cauda alongada (F) 6 dias - (vepd) vesícula óptica em processo de diferenciação; (rp) retina pigmentada; (r) ranfoteca; (mta) membro torácico alongado; (mpa) membro pélvico alongado. Barras referentes a $2 \mathrm{~cm}$.

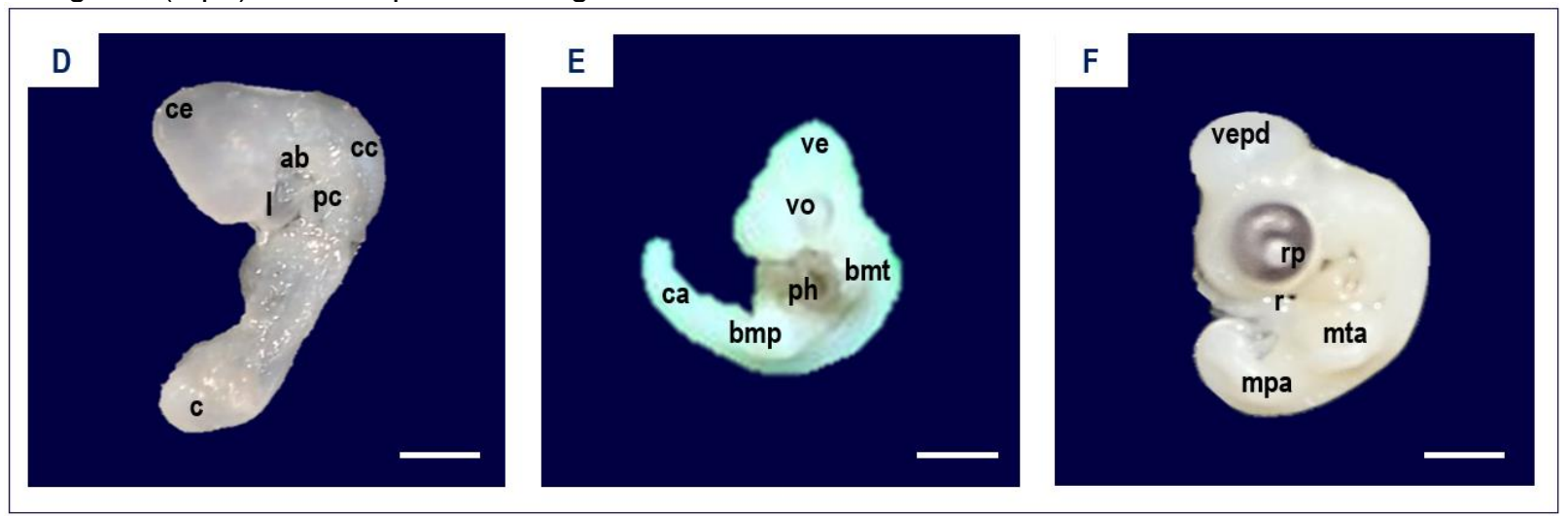

Fonte: Assunção (2019). 
Os embriões coletados no intervalo compreendido entre 7 a 9 dias do desenvolvimento embrionário, com peso corporal entre $0,21 \mathrm{~g}$ e 1,44g, respectivamente, apresentaram características morfológicas marcantes e possíveis de serem observadas a olho nu: os membros pélvicos e torácicos (ou asa) apresentavam indícios de desenvolvimento dos dígitos. Nesses, a margem radial da asa apresentava o primeiro dígito discernível. Notou-se ainda a diferença existente entre a ranfoteca (ou bico) e a mandíbula, seguida pelo alongamento tanto da própria mandíbula quanto do pescoço. Na região caudal notou-se a presença de penugem. Notava-se ainda a abertura da cavidade bucal, e a presença de olhos proeminentes com circunferências elipsoidais (Figura 4).

Figura 4 - Fotodocumentação da vista lateral esquerda, dos embriões de aves (Gallus gallus domesticus) no intervalo de 7 a 9 dias do desenvolvimento. (G) 7 dias - (d) dígitos. (H) 8 dias - (p) penugem. (I) 9 dias - (op) olho proeminente; (pa) pescoço alongado; (m) mandíbula; (d) dígitos. Barras referentes a $2 \mathrm{~cm}$.

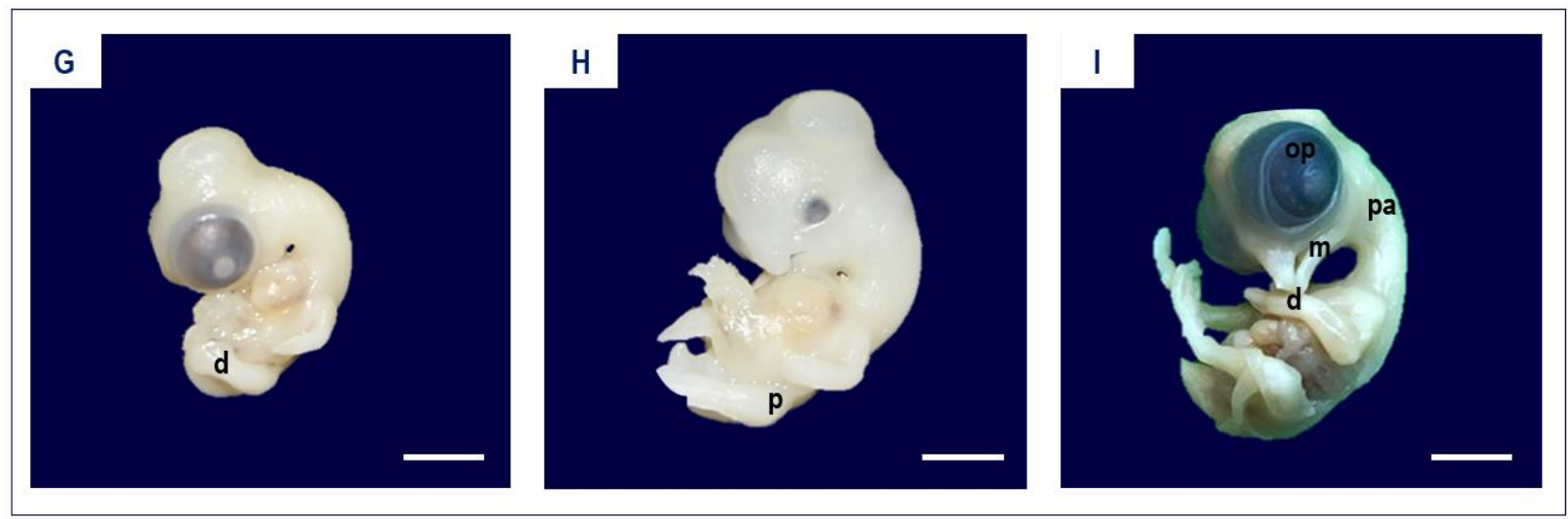

Fonte: Assunção (2019).

Com intervalo de 10 a 12 dias do desenvolvimento embrionário, apresentando um peso corporal entre $1,64 \mathrm{~g}$ e $3,86 \mathrm{~g}$, as aves demonstravam corneificação e alongamento da ranfoteca (ou bico), desenvolvimento de garras, cauda recoberta de penugem, bem como o desenvolvimento de escamas nos membros pélvicos. O meato acústico externo e membrana nictante cobrindo um quarto do olho estavam presentes (Figura 5). 
Figura 5 - Fotodocumentação, vista lateral esquerda, dos embriões de aves (Gallus gallus domesticus) no intervalo de 10 a 12 dias do desenvolvimento. (J) 10 dias - (g) garras. (K) 11 dias - (mae) meato acústico externo; (mn) membrana nictante; (p) penugem. (L) 12 dias - (ra) ranfoteca alongada; (e) escamas. Barras referentes a $2 \mathrm{~cm}$.

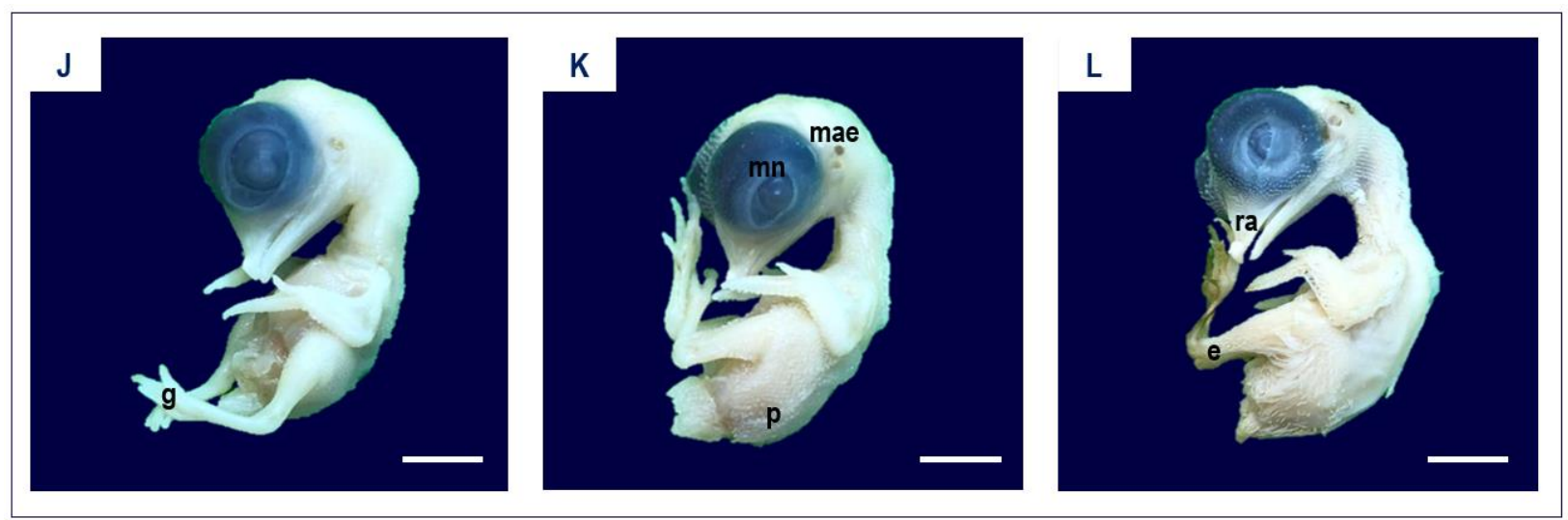

Fonte: Assunção (2019).

Os embriões coletados durante o intervalo de 13 a 15 dias do desenvolvimento embrionário, com peso corporal entre $6,12 \mathrm{~g}$ e 12,27g, respectivamente, apresentaram características morfológicas visíveis: desenvolvimento da orelha externa, pálpebras formadas, ranfoteca completamente cornificada. Na ranfoteca havia a formação do dente de ovo e uma breve torção da cabeça (quando no ovo) para posterior quebra da casca e posicionamento da cabeça em direção ao abdômen (Figura 6).

Figura 6 - Fotodocumentação, vista lateral esquerda, dos embriões de aves (Gallus gallus domesticus) durante o intervalo de 13 a 15 dias do desenvolvimento. (M) 13 dias - (do) dente de ovo. (N) 14 dias (p) pálpebras; (r) ranfoteca. (O) 15 dias - (seta amarela) cabeça em direção ao abdômen. Barras referentes a $2 \mathrm{~cm}$.

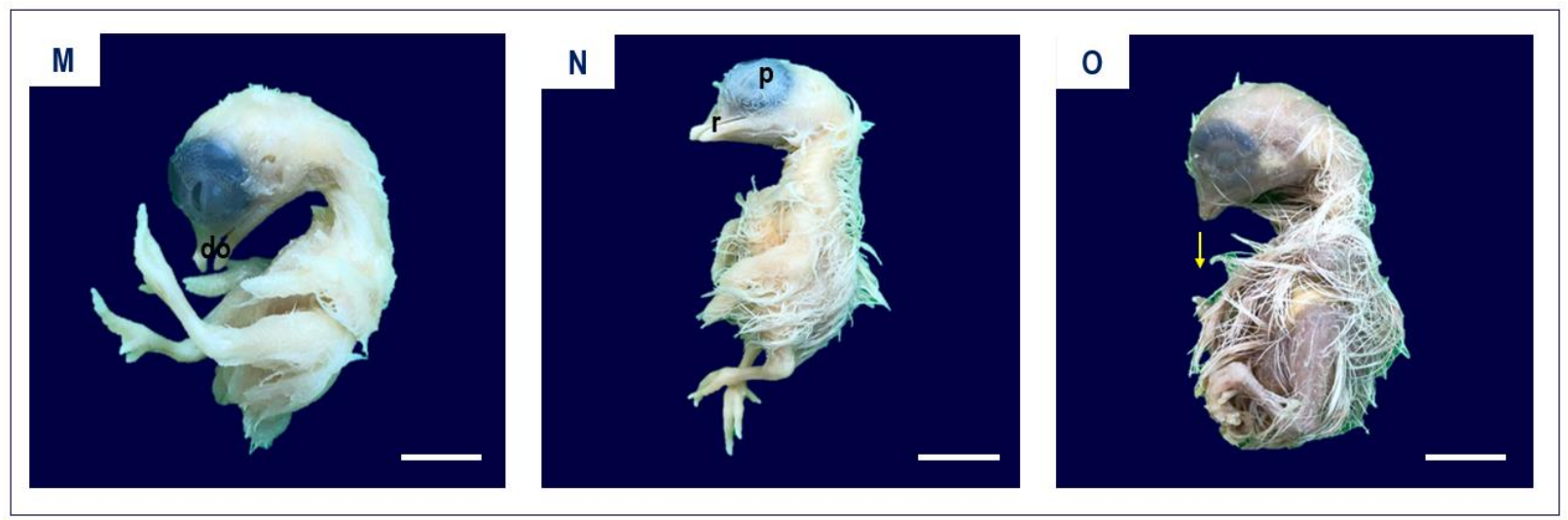

Fonte: Assunção (2019).

Durante o intervalo de 16 a 18 dias do desenvolvimento, as aves apresentavam peso corporal entre 14,21g e 18,30g. Nessa ordem, os embriões demonstravam o corpo completamente coberto de penugem, no ovo - apresentavam-se graus de 
direcionamento da ranfoteca para a câmara de ar corroborando com o preenchimento de todo o espaço disponível no ovo pelo corpo do concepto (Figura 7).

Figura 7 - Fotodocumentação, vista lateral esquerda, dos embriões de aves (Gallus gallus domesticus) com intervalo de 16 a 18 dias do desenvolvimento. (P) 16 dias. (Q) 17 dias. (R) 18 dias. Barras referentes a $2 \mathrm{~cm}$.

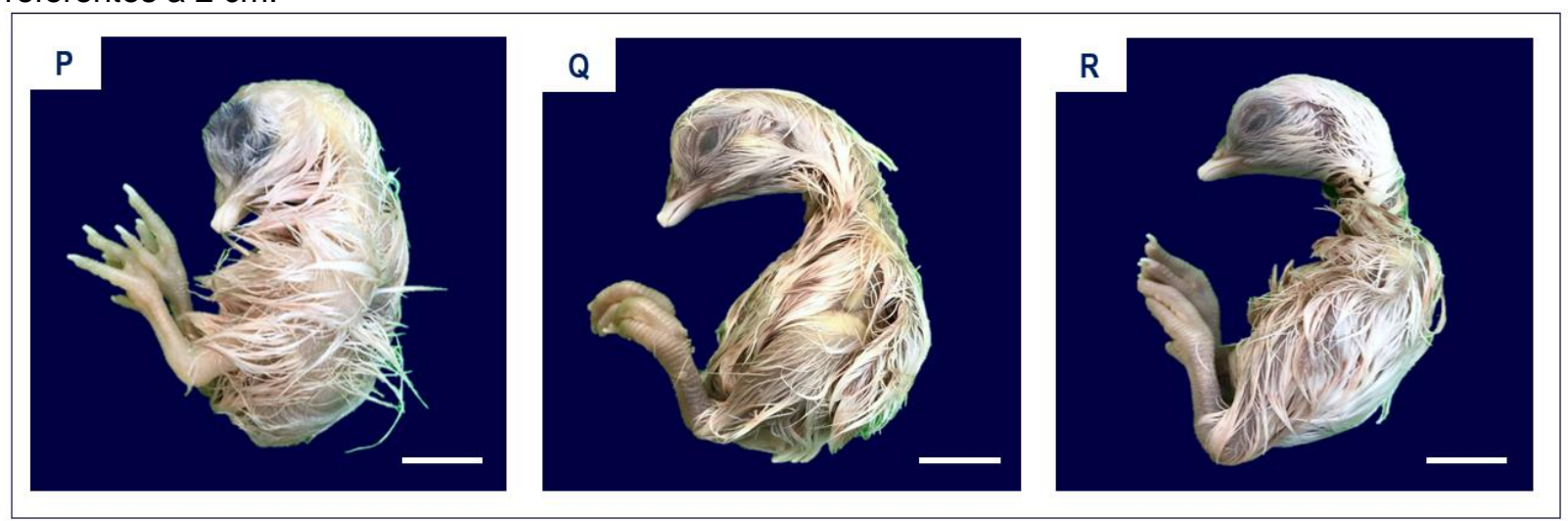

Fonte: Assunção (2019).

Os embriões coletados durante o intervalo entre 19 a 21 dias, com peso corporal entre $21,10 \mathrm{~g}$ e 24,40g, respectivamente, apresentaram características morfológicas ultra estruturais visíveis no ovo tais como involução vitelínica aos 19 dias, momento no qual o saco vitelínico encontrava-se completamente absorvido pelo embrião. Aos 20 dias apresentavam o início do processo de eclosão fazendo com que as trocas gasosas ocorressem mediante a casca do ovo (que é porosa). Aos 21 dias as aves iniciavam o processo de eclosão (ou apto ao nascimento), estando completamente formados para ganhar o meio externo (Figura 8).

Figura 8 - Fotodocumentação, vista lateral esquerda, dos embriões de aves (Gallus gallus domesticus) com intervalo de 19 a 21 dias do desenvolvimento. (S) 19 dias. (T) 20 dias. (U) 21 dias. Barras referentes a $2 \mathrm{~cm}$.

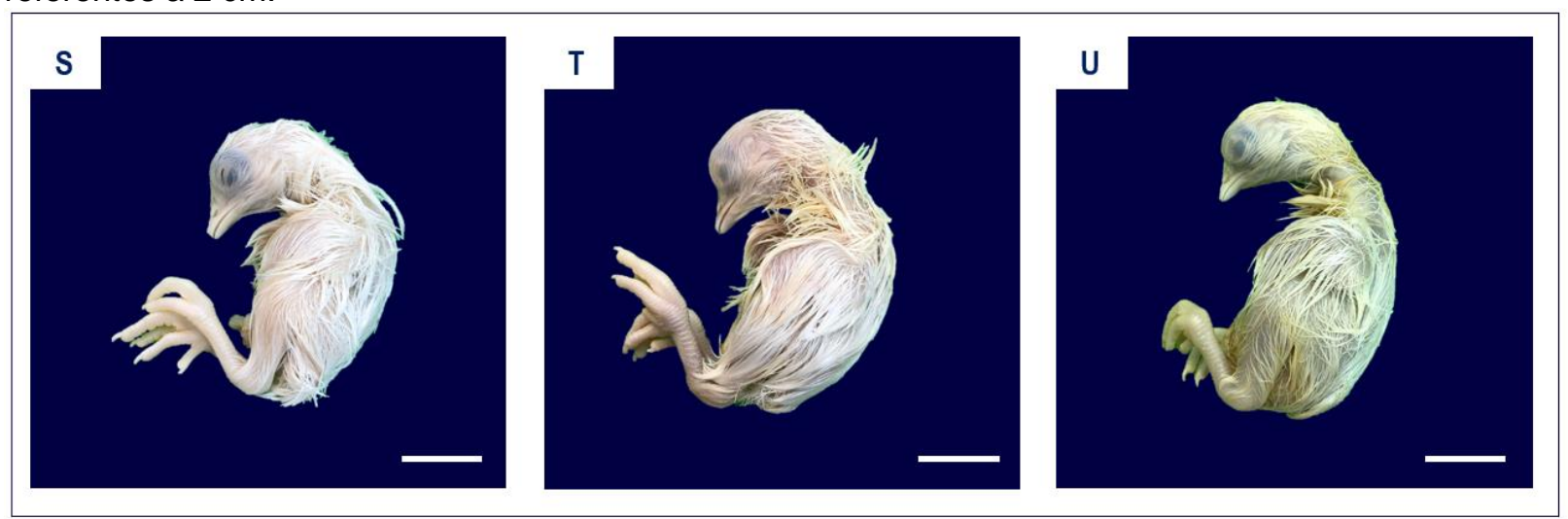

Fonte: Assunção (2019). 


\subsection{AMBIENTE VIRTUAL}

\subsubsection{A criação da plataforma digital}

A plataforma digital "Embriologia comparativa" como fonte de um novo recurso didático, foi desenvolvida mediante a efetuação do cadastro e a confirmação do e-mail inseridos na base de dados da plataforma EAD GURU (https://ead.guru). Após a validação do e-mail, realizou-se o login no Painel de Controle (Figura 9) e definiu-se a titulação para a plataforma.

Figura 9 - Print da aba inicial da plataforma EAD GURU para acesso ao painel de controle visualizado por meio da indicação da seta vermelha.

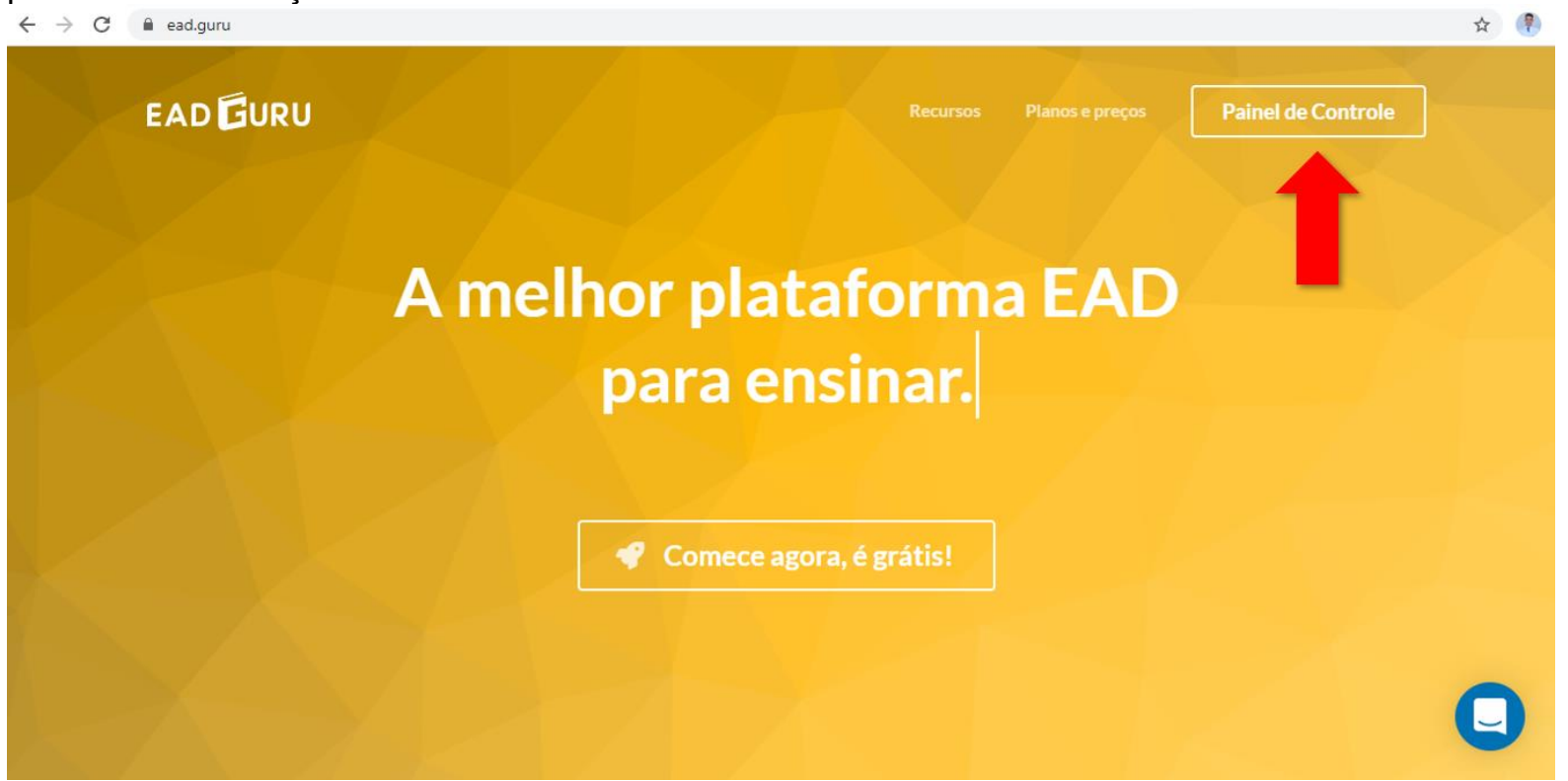

Fonte: Assunção (2020).

Mediante o preenchimento de todos os campos obrigatórios para a criação da plataforma foi possível estabelecer link para a própria página da Plataforma digital "Embriologia comparativa". O acesso é possível por meio do endereço eletrônico https://embriologiacomparativa.ead.guru (Figura 10) e do código de barras bidimensional feito a partir de uma forma de pixeis pretos e brancos, ou seja, QR CODE - QR que significa “Quick Response” (Resposta rápida), referindo-se à leitura rápida de acesso ao conteúdo. Assim, todo o conteúdo armazenado no código pode então ser descodificado e exibido utilizando a câmera de um Smartphone ou Tablet (Figura 11). 
Figura 10 - Página inicial de boas-vindas à plataforma "Embriologia Comparativa".
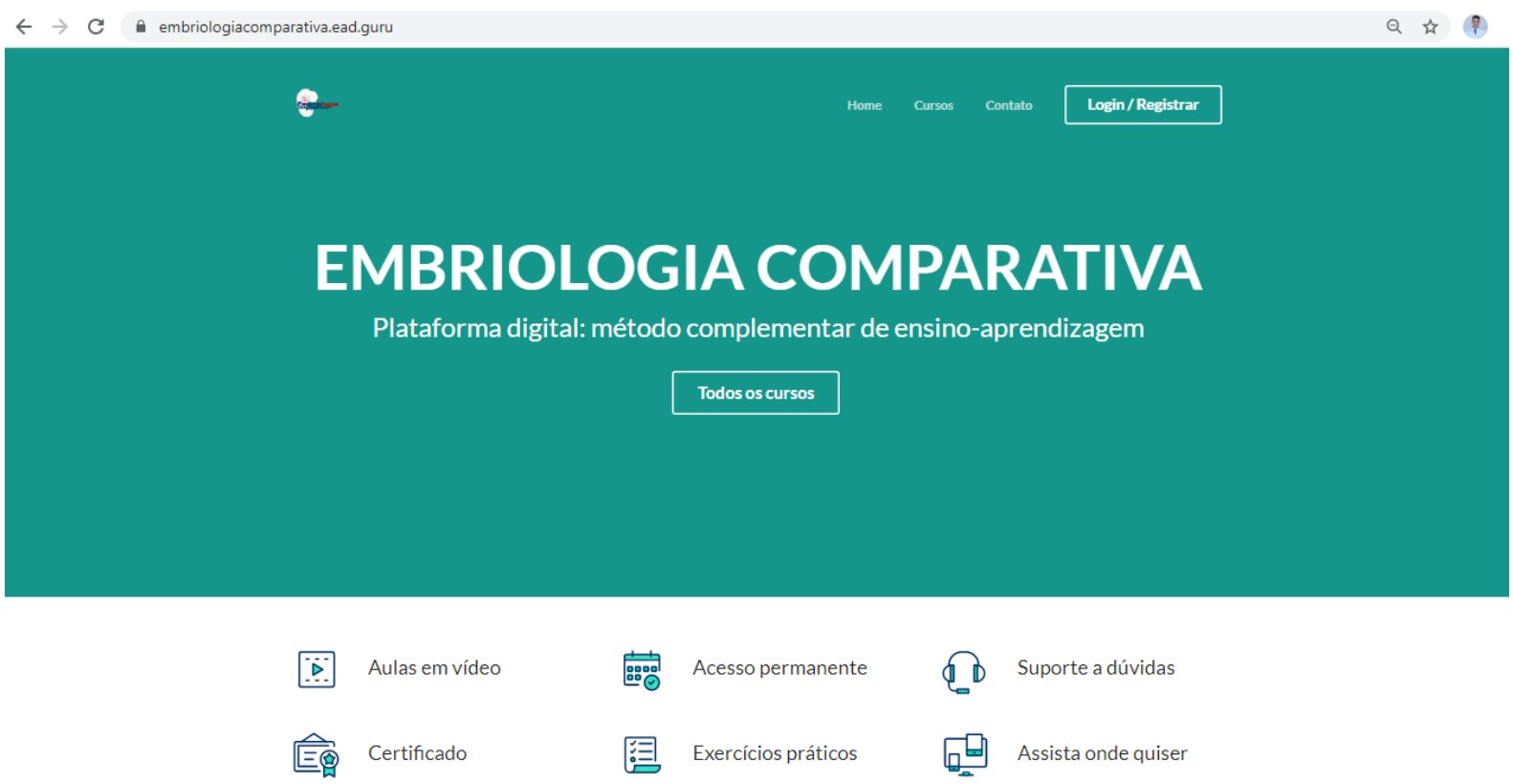

Fonte: Assunção (2020).

Figura 11 - QR CODE para acesso a plataforma "Embriologia Comparativa". Faz-se necessário a utilização da câmera tanto de Smartphone quanto de Tablet para o acesso.

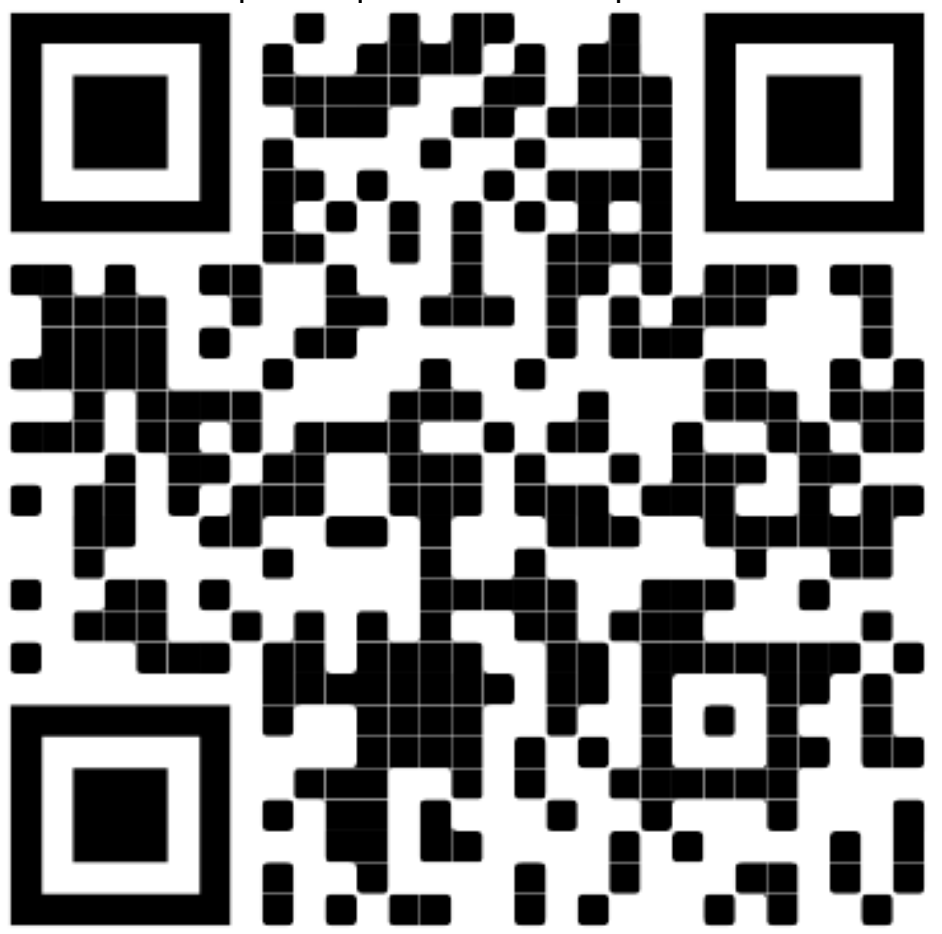

Fonte: Assunção (2020).

Ao acessar a plataforma, ainda na página inicial (Home), o espectador poderá ter acesso à descrição do curso que se encontra disponível na aba Sobre o Curso, bem como a Ementa, Perguntas frequentes e Sobre o instrutor. Ao final da página 
inicial, é possível ainda ter acesso ao E-mail institucional, Termos de uso e às Nossas redes sociais (https://instagram.com/embriologiacomparativa).

\subsubsection{Acesso ao conteúdo}

Para acesso aos conteúdos disponíveis que se refere ao módulo I torna-se necessário efetuar a matrícula/cadastro, ao clicar na aba Matricule-se ao início da página inicial o estudante é direcionado para Registrar ou ter acesso a sua conta (caso já possua cadastro) (Figura 12).

Figura 12 - Representação da aba de registro cadastral na plataforma "Embriologia comparativa". Por meio do retângulo vermelho é possível observar o campo de preenchimento dos dados cadastrais exigidos.

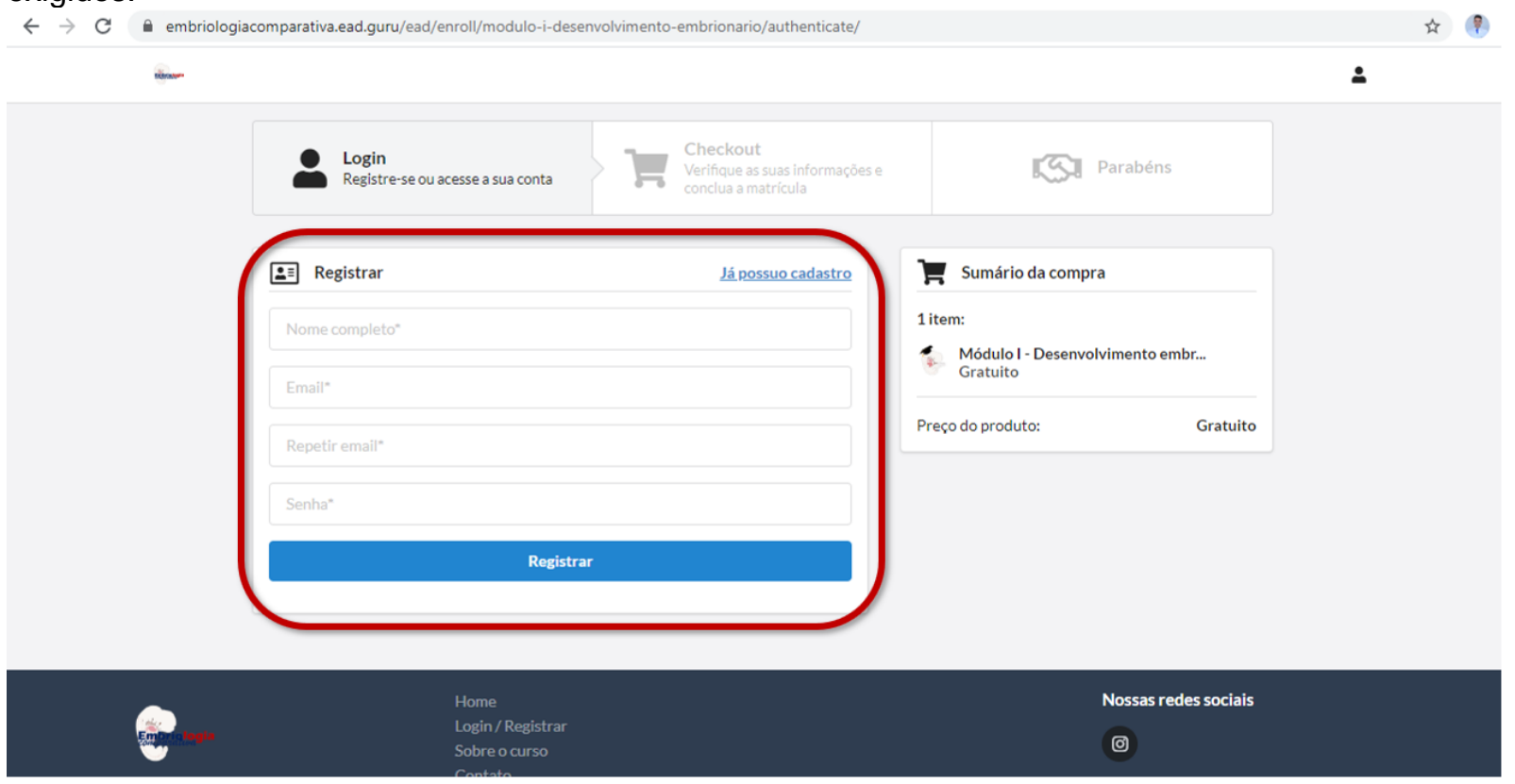

Fonte: Assunção (2020).

Após a autenticação dos dados cadastrais e acesso de fato na plataforma, no rodapé ao clicar na aba Home e em seguida Matricule-se (canto superior direito da tela) torna-se possível efetuar a matrícula no módulo I de cursos (Figura 13). Com a inscrição efetuada com sucesso a matrícula torna-se liberada (Figura 14). 
Figura 13 - Página para realização da matrícula acerca do produto disponível na plataforma "Embriologia comparativa". Clicar na aba em laranja (matricular-se).

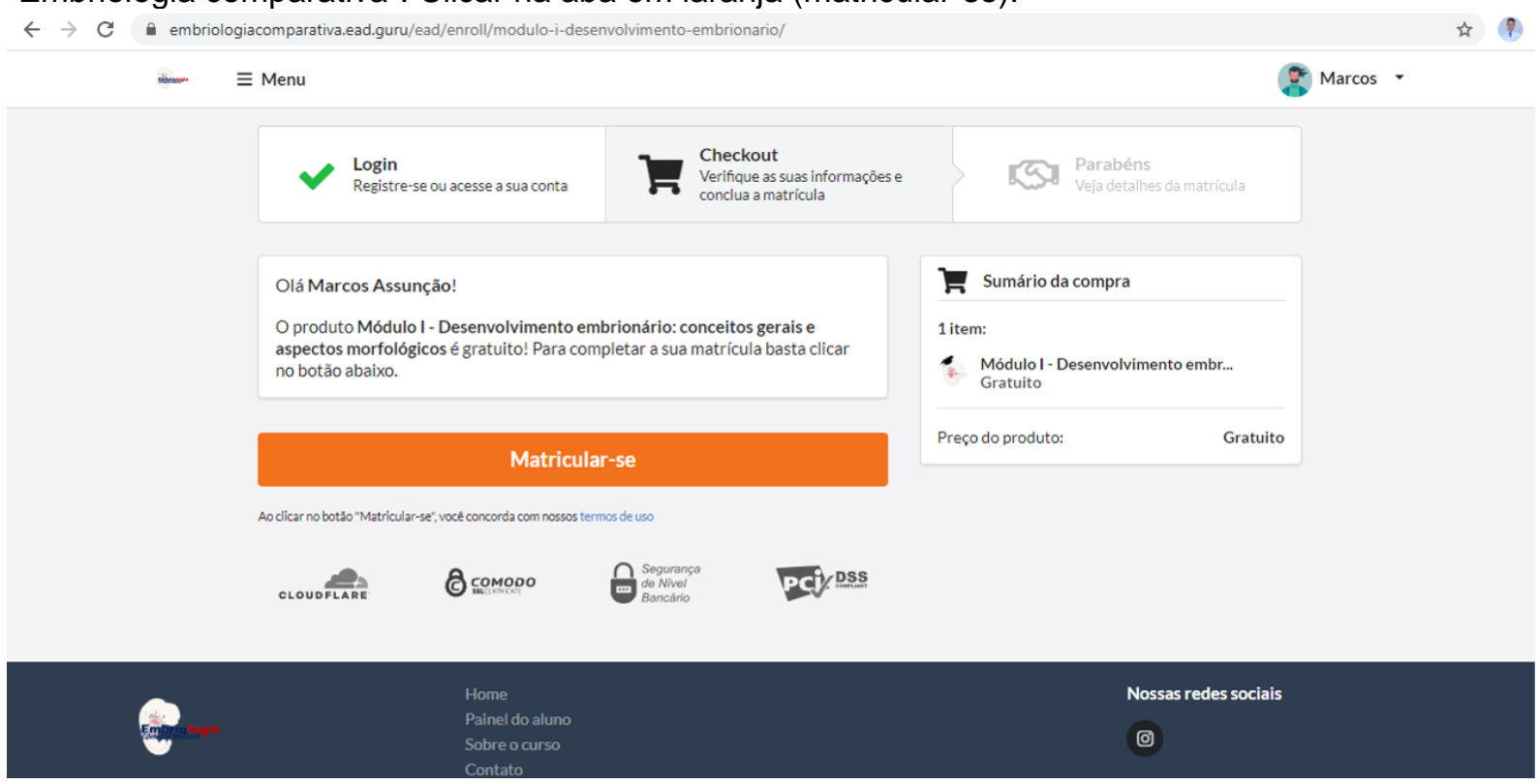

Fonte: Assunção (2020).

Figura 14 - Página de direcionamento para os cursos disponíveis na plataforma "Embriologia comparativa". Deve-se clicar no retângulo azul (ir para meus cursos).

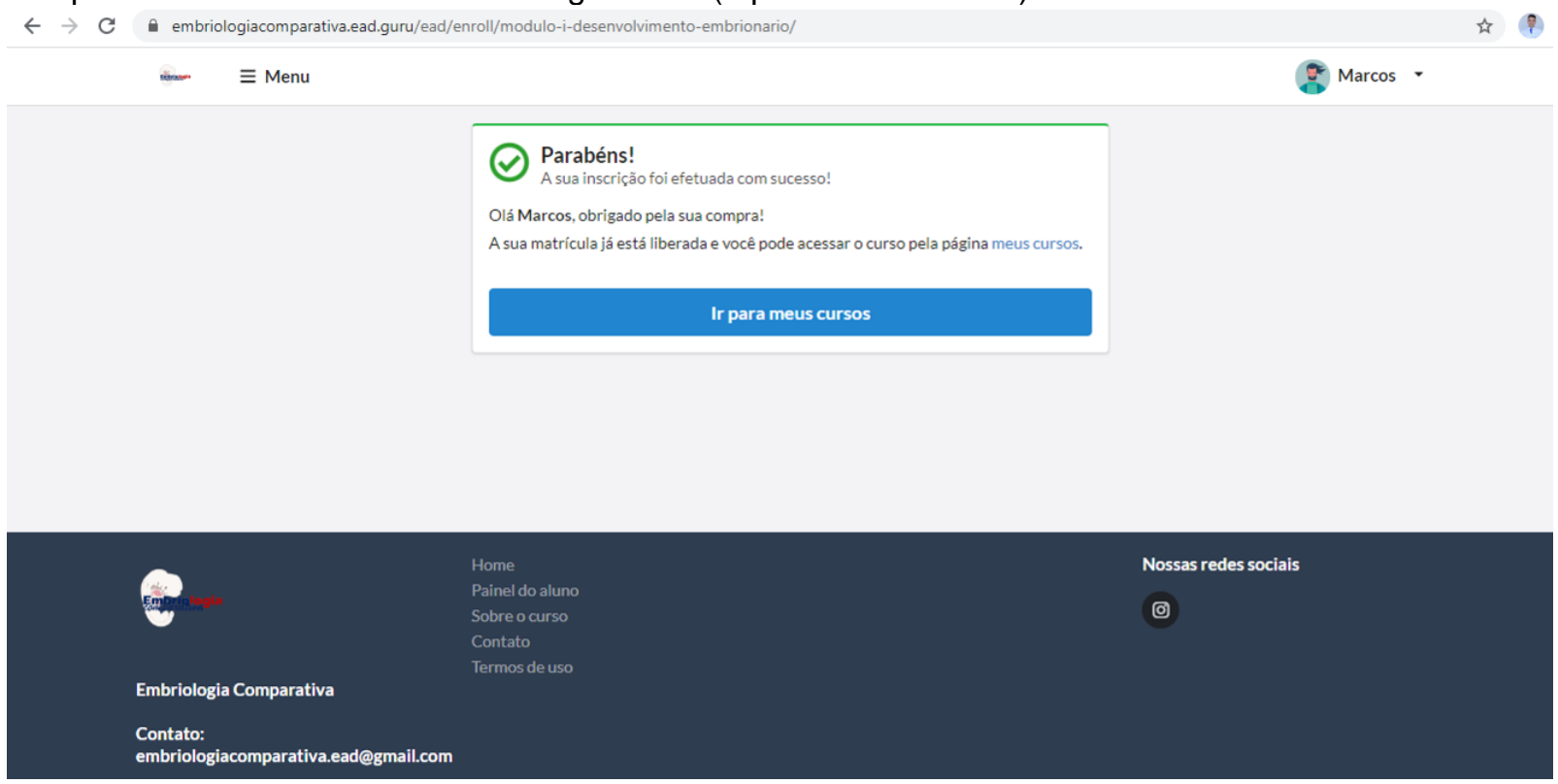

Fonte: Assunção (2020).

Seguindo os passos acima, é possível ter acesso aos cursos disponíveis por meio da aba Meus cursos, ao clicar na área demarcada (Figura 15) dá-se o direcionamento para acesso aos conteúdo e arquivos do módulo proposto (Figura 16). 
Figura 15 - Aba, meus cursos, disponível na plataforma "Embriologia comparativa". Deve-se clicar na aba demarcada pelo retângulo vermelho para acesso aos conteúdos.

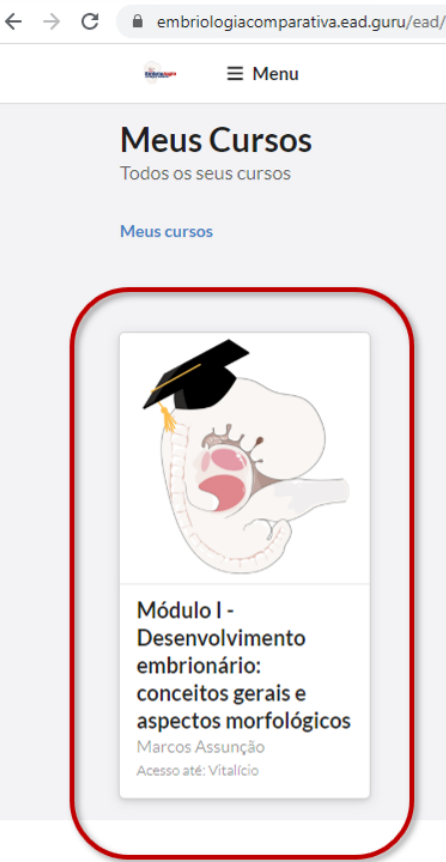

8 Marcos.

Meus Cursos

dos os seus cursos

Desenvolvimento

embrionário:

aspectos morfológicos

Fonte: Assunção (2020). 
Figura 16 - Organização do percurso formativo referente ao módulo I - Desenvolvimento embrionário: conceitos gerais e aspectos morfológicos disponível na plataforma "Embriologia Comparativa".

Módulo I - Desenvolvimento embrionário: conceitos gerais e aspectos morfológicos

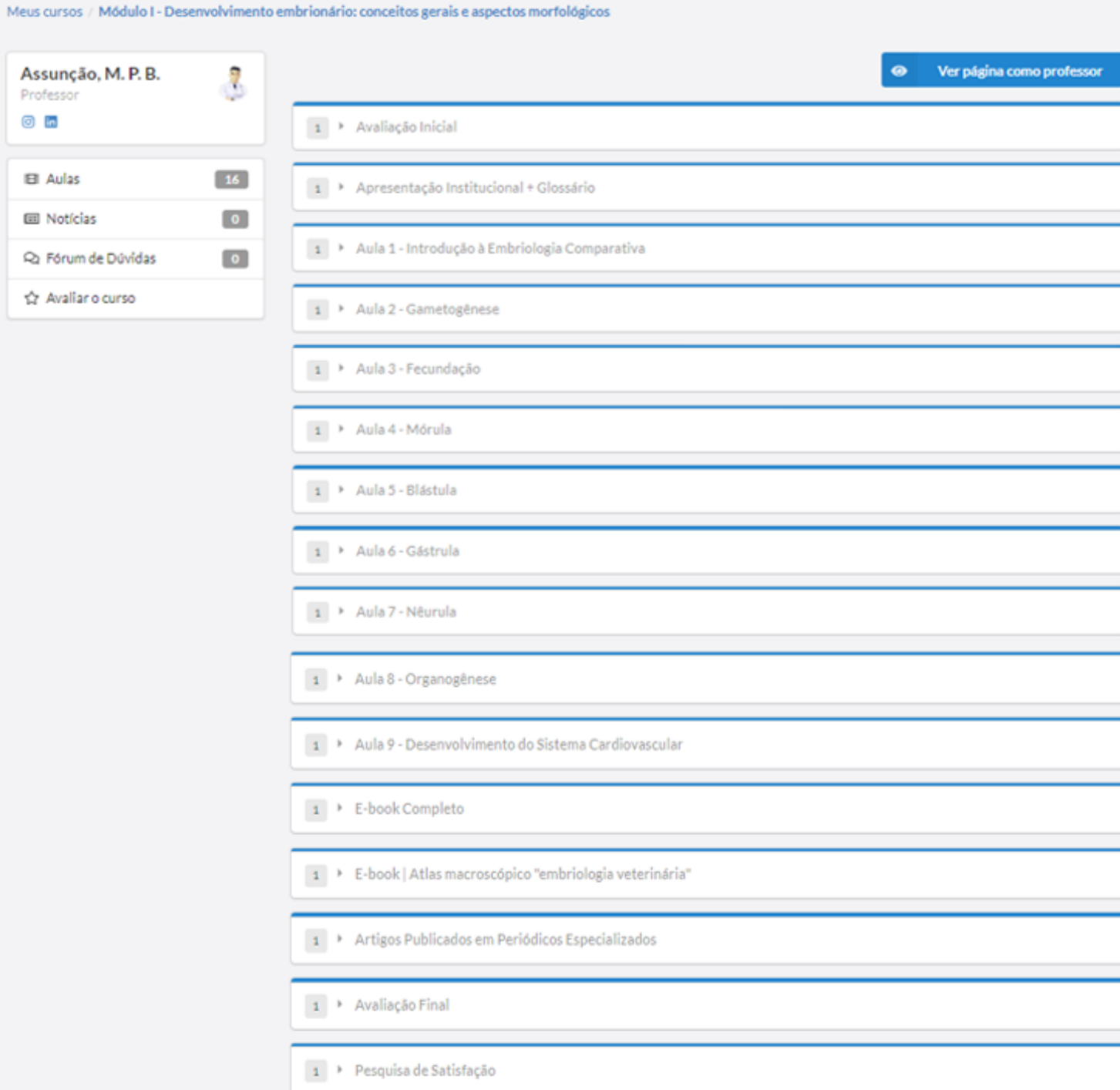

Fonte: Assunção (2020).

O percurso formativo disponível na plataforma, após a organização pedagógica (observado por meio da Figura 16) constitui-se de avaliações tanto inicial quanto final, isso para que seja possível verificar a aprendizagem antes e após o acesso ao conteúdo (APÊNDICE A. p, 85).

A plataforma disponibiliza de um glossário para definição dos termos que rege tal área do conhecimento, contando ainda com capítulos referente aos processos embrionários que ocorrem ao longo do desenvolvimento, ou seja, entre a fecundação e o nascimento, sendo: introdução à embriologia comparativa, gametogênese, fecundação, mórula, blástula, gástrula, nêurula, organogênese e do desenvolvimento do sistema cardiovascular que em sua constituição apresenta atividades 
complementares e ilustrações didáticas (APÊNDICE B. p, 101). Para além disso, os usuários autenticados gozam de arquivos como produtos de apoio ao material pedagógico: vídeo aulas e podcasts em pequenas cápsulas de 6 a 8 minutos compreendendo uma unidade de medida de informação equivalente a 5,5 a 6,0 megabytes (MB) para os podcasts e de 134,2 a 144,9 MB para vídeo aulas referente a cada capítulo/aula (APÊNDICES C. p, 199 e APÊNDICE D. p, 200).

$\mathrm{Na}$ tela Meus cursos, as seções criadas e publicadas se dispõem de prérequisitos para avanço ao conteúdo. Neste contexto, como transposição didática acerca da temática, a plataforma conta com atlas figurativo da morfologia ultra estrutural do desenvolvimento de aves (Gallus gallus domesticus), o mesmo apresenta contextualização teórica e foi desenvolvido como modelo de material didático para possível expansão às demais espécies domésticas (APÊNDICE E. p, 201), artigos publicados em periódicos que contemplam e fazem parte da proposta do nosso trabalho (APÊNDICE F. p, 240) e pesquisa de satisfação (APÊNDICE G. p, 248).

Os questionários, bem como a pesquisa de satisfação se apresentam como parte da verificação da aprendizagem e possibilita a discussão que são pertinentes aos alcances e as limitações do uso de plataformas como ferramenta didática alternativa ao processo de ensino-aprendizagem. Portanto, ambos os recursos podem ser respondidos via Google Forms com URL (Uniform Resource Locator) de redirecionamento nas seções presentes na plataforma. 


\section{DISCUSSÃo}

O pilar para a construção da referida proposta se dá mediante o estudo da embriogênese, a qual está correlacionada com uma série de mudanças que ocorrem de forma gradual para formação da espécie (KNOSPE, 2002; BEAUDOIN et al., 2003; HYTTEL et al., 2010).

Diante o exposto, o material didático instrucional encontra-se hospedado na Plataforma EAD Guru (https://ead.guru). O ambiente virtual de ensino-aprendizagem intitulado "Embriologia comparativa" (https://embriologiacomparativa.ead.guru) está estruturado com nove aulas que constituem o módulo I e deve ser aplicado de maneira complementar para a formação de biólogos, médicos veterinários, etc. Todo o material apresenta-se como uma oportunidade para que estudantes, professores e pesquisadores tenham acesso aos conceitos biológicos envolvidos ao longo do desenvolvimento de espécie-especificas, bem como sobre os conceitos utilizados sobre o tema mediante o desenvolvimento do glossário, estabelecendo conexões entre os novos conhecimentos e os já assimilados, além de estabelecer uma proatividade em relação à busca do conhecimento e da sua aplicação crítica.

Ademais, a utilização de recursos complementares no que se refere aos materiais didáticos instrucionais, incentiva a modernização de técnicas para o ensino da embriologia, experienciando a prática profissional e integrando os conhecimentos de outras disciplinas como a Anatomia descritiva de animais domésticos, por exemplo.

Para o desenvolvimento dos conteúdos que juntos constitui o módulo I disponível na Plataforma "Embriologia comparativa" levou-se em consideração o clico de aprendizado de Kolb (2014) que se baseia nas origens das obras de Piaget, Lewin e Dewey onde os espectadores tenham uma experiência concreta, uma observação reflexiva, permitindo que haja uma conceitualização abstrata após o acesso, ou seja, mediante experimentação ativa por parte dos usuários. Isso configura o desenvolvimento de habilidades cognitivas superiores permitindo que os alunos apliquem e pratiquem o que aprenderam em contextos autênticos (DALE; SULLIVAN; MAY, 2008; KERR; MULLAN; MAIN, 2013; KOLB, 2014).

Acredita-se que na sala de aula virtual impulsiona a experiência que 0 estudante já possui das aulas presenciais ou mesmo ser acessado como uma aula invertida. Assim, a Plataforma "Embriologia comparativa" é uma ferramenta desenvolvida por meio da base de dados da EAD Guru e se apresenta como uma 
ferramenta útil e valiosa para aprendizagem ativa, de fácil acesso, baixo custo e que possibilita a comunicação entre professores e estudantes, permite acesso a arquivos midiáticos como vídeo aulas e podcasts. Os formulários que juntos constituem o processo avaliativo e que podem ser respondidos via Google Forms com link de acesso na seções disponíveis na Plataforma, são imprescindíveis para o aprimoramento e interação entre o instrutor e os alunos matriculados, além de aumentar a motivação, o engajamento e o aprendizado adquirido (VAHALIA et al., 1995; CAMPBELL, 2011; IFTAKHAR, 2016; CARVALHO, 2017; CHAIYO; NOKHAM, 2017; AZHAR; IQBAL, 2018; HEGGART; YOO, 2018; RAMADHANI et al., 2019; ROJAS et al., 2020).

A transposição didática foi realizada utilizando Photoshop e uma mesa digitalizadora. O uso da imagem associada às inter-relações do desenvolvimento embrionário se revela como um importante recurso didático e promovem uma aprendizagem de mais ampla compreensão para o aluno no momento da explanação dos conteúdos na sala de aula, seja ela virtual e/ou presencial, sendo assim, a sua utilização de extrema importância no processo de ensino-aprendizagem (DRAKE, 2014; ROXO, 2015; MAIA, 2017; ROJAS et al., 2020). Com o uso de imagens transpostas a serem utilizadas como método complementar para fins acadêmicos e também científicos, reduz o número de animais utilizados em experimentação e, consequentemente, a limitação de acesso aos materiais biológicos para diversos fins, são eliminados (SAMAR \& AVILA, 2007; FERREIRA \& KEMPINAS, 2010; FERREIRA, 2011).

Seguindo as premissas acima, o uso de imagens também torna o produto disponibilizado mais atrativo, incrementando o seu poder comunicativo, por explanar, amplificar e ilustrar a mensagem contida no material teórico. Os processos biológicos que ocorrem de forma dinâmica são definidos quase completamente pelo seu uso e trazidos para dentro da sala de aula. Durante a produção de todo o material didático, procurou-se desenvolver imagens fidedignas, textos exemplificados, linguagens claras e objetivas que refletem aos conceitos dos processos envolvidos no desenvolvimento embrionário (JOTTA, 2005).

Com relação ao ensino a distância, o mesmo é referenciado pela prestação de recursos de ensino-aprendizagem que ocorrem sem limite de tempo e espaço, ou seja, sem horário e local físico para que o docente e discente se encontrem pessoalmente, permitindo a otimização. Em ascensão, o ensino a distância apresenta 
maior número de ofertas de vagas, e, este, é agraciado pelo interesse de instituições públicas e privadas (ABMES, 2020). Para tanto, o processo de virtualização da sala de aula ocorre com a popularização do uso de ambientes virtuais de aprendizagem. A relação tempo-espaço ocorre porque o presencial se virtualiza e a distância se presencializa, uma vez que, os encontros em um mesmo espaço físico se combinam com os encontros virtuais, à distância, mediante utilização da Internet (MORAN, 2007). O autor relata ainda que o grande desafio da virtualização é recriar a riqueza de possibilidades de aprendizagem do bom campus presencial. Desta forma, os ambientes virtuais envolvidos no processo de ensino-aprendizagem certamente trazem vantagens e desvantagens ao projeto pedagógico educacional (SHORT, 2002; ERTMER; NOUR, 2007; ERTMER; NOUR, 2007; MACDONALD, 2008; CAETANOSIMÕES, 2009; ANTÚNEZ et al., 2013).

Assim, a virtualização, ou seja, a educação assistida, assume seu papel na educação global, tornando-se um recurso complementar a aulas tradicionais/presenciais, aumentando as oportunidades para que os estudantes em todo o mundo tenham acesso ao ensino com base em sua localização. Logo, a facilitação do ensino a distância tem o potencial de melhorar o desempenho acadêmico e obter vantagem competitiva sustentável no ensino de ciências animal. No início do século XXI, os estudos sobre a qualidade do ensino não presencial se concentraram em três pilares tidos como tríade essencial para a oferta de um curso com qualidade: material didático, tutoria e avaliação. No entanto, novas pesquisas apontam para um novo pilar: o método empregado (KASEMSAP, 2019; ABED, 2019; ROJAS et al., 2020).

No que se refere ao uso de ambientes computacionais e seus recursos, estes constituem, portanto, um ambiente extremamente rico, de que docentes possam lançar mão para desenvolverem conteúdos relacionados com as diferentes áreas do conhecimento como, por exemplo, a embriologia comparativa. A escolha de ambiente virtual vincula-se a diversos aspectos tanto teóricos, como metodológicos, porém um dos aspectos fundamentais consiste na mediação do professor (ASSUNÇÃO \& MIGLINO, 2020). Os autores ainda relatam que uso de recursos extras no processo de ensino-aprendizagem se mostra essencial e eficaz para a aquisição de conhecimentos, mas que, dada sua complexidade, é necessária uma abordagem de forma multidisciplinar, a fim de que haja motivação para se promover uma formação mais efetiva do aprendizado. Para refinar tal método dentro da Ciências Biológicas e 
Medicina Veterinária, sugere-se que as abordagens complementares de ensino, como a sala de aula virtual estejam vinculadas a melhores resultados de aprendizado a fim de apoiá-los em sua preparação para a prática, integrando seu aprendizado a novos contextos (DRAKE, 2014; ROXO, 2015; DAY, 2018; FLEAGLE et al., 2018; SANDRONE et al., 2020; ASSUNÇÃO \& MIGLINO, 2020).

Embora as dissecções e observações macroscópicas físicas permita maior conhecimento sobre estruturas, funções e evolução filogenética, e são consideradas como base para habilidades avançadas em preparação de amostras biológicas, pesquisa em anatomia e embriologia comparada permite o acesso aos tecidos e órgãos que constituem o corpo dos animais. Mas, que ao mesmo tempo tal prática pode apresentar um fator limitante para alguns cursos e instituições, uma vez que, o uso de animais pode se tornar inviável e pareceres bioéticos tornam inviável o uso de materiais biológicos, favorecendo o uso de métodos complementares de alta qualidade. Além disso, as coleções de Embriologia em cada instituição de ensino geralmente compreendem a fauna regional, fato este que muitas vezes limita 0 processo comparativo taxonomicamente amplificado, especialmente nas aulas de Embriologia Animal para as Ciências Biológicas. Por isso, as imagens geradas em alto-relevo tridimensionais a partir de softwares de baixo custo como o Photoshop, quando utilizando habilidades e conhecimentos da área apresenta-se como um recurso fidedigno para driblar as questões limitantes encontradas durante o percurso formativo de aprendizagem (DE VILLIERS; MONK, 2005; THOMAS; FORDYCE, 2012; DRAKE, 2014; ROXO, 2015; CROWTHER; BAILLIE, 2016; THOMAS et al., 2016).

Nesse ínterim, apostar em técnicas mediante a utilização de softwares para elaboração de imagens em alto relevo (ou em aspecto 3D) associada a plataformas digitais de ensino EaD, contribui na complementação de lacunas e quebra de paradigmas no processo de ensino-aprendizagem da embriologia veterinária, mitigando a falta de acervos de muitas universidades brasileiras, e engloba uma tendência no ensino multidisciplinar nas áreas das ciências biológicas e veterinária. Massari et al., (2018) reportaram que tal alternativa didática não substitui as aulas laboratoriais, mas que complementa o método tradicional e inclui a tendência tecnológica existencial no processo de ensino-aprendizagem.

Para a realização da transposição didática acerca dos espécimes coletados nesta tese, deparou-se com dificuldades para resignação da imagem para o mais 
semelhante possível do real, fato esse também relatado por Gross et al., (2014) em processo de biomodelagem. Mesmo sabendo da importância de aprimoramentos fundamentais e de domínio acerca das técnicas digitais utilizando softwares, tal realização de novas metodologias ameniza constantemente os problemas associados ao déficit de infraestrutura para a práxis didáticas no ensino da embriologia veterinária, uma vez que, segundo o Conselho Federal de Medicina Veterinária (2020) atualmente existem mais de 350 cursos de graduação em Medicina Veterinária, além de outros cursos relacionados, como, por exemplo, a Ciências Biológicas.

A produção de materiais didáticos instrucionais que inclui a elaboração de um glossário, como apresentado neste trabalho, é de fundamental importância no auxílio tanto para o professor quanto para o aluno durante a transmissão dos conteúdos, sendo este o pilar para o fornecimento de informações mais detalhadas (OLIVEIRA et al., 2013). Tal conteúdo complementar configura-se como uma parte da ferramenta midiática para consulta dos alunos disponível mesmo após a aula, pois, aborda de maneira bem ilustrativa os vários termos científicos que são utilizados para se explicar os processos envolvidos ao longo do desenvolvimento embrionário comparativo, sendo este um recurso didático a mais, ou seja, como um ponto de partida, e não como uma atividade final. Ao elaborar este tópico no trabalho o intuito vai de encontro ao processo de socialização do conhecimento que se refere ao tema, sendo este acompanhado por outras atividades complementares, bem como a leitura da bibliografia recomendada e dos capítulos disponíveis, videoaulas e podcasts.

Com a irrupção do novo coronavírus (SArVS-CoV-2) que logo se espalhou pelo mundo no final de 2019, gerou impactos direto no desenvolvimento social, econômico, educacional e cultural em vários países se estende até os dias atuais (HEYMANN; SHINDO, 2020; RODRIGUEZ-MORALES et al., 2020). A influência da doença (COVID-19) afetou constantemente o processo de ensino-aprendizagem no Brasil nas mais diversas áreas, realidade esta que chega aos cursos de graduação em Medicina Veterinária, Biologia e Zootecnia. No entanto, como nem tudo está perdido, o projeto intitulado "School's Out, But Class's On" apostou na ideia da aprendizagem por meio do ensino online, onde os ambientes virtuais de aprendizagem possuem forte poder de transformação social e se apresenta como um novo modelo de plano curricular para driblar crises educacionais (ZHOU et al., 2020; HAYASHI, 2020). Em linhas gerais, os autores trazem o despertar e a motivação de futuras comutações a serem realizadas no Ensino Superior para a formação continuada e de qualidade. 
As medidas adotadas por cada estado brasileiro, em sua maioria, optaram pelo isolamento social (outros até mesmo pelo lockdown), em vários deles tal medida se estende até o final do ano de 2020. Os estados que mais sofreram com o caos gerado na saúde pública e que afetou diversos setores no país, estão São Paulo, Amazonas e Ceará. Na grande São Paulo, na área do ensino, muitos Professores tiveram que se adaptar as novas medidas adotadas pelo o Governo do Estado, ou seja, os conteúdos eram transmitidos virtualmente por tele aulas. As plataformas utilizadas por cada Instituição variam de acordo com cada realidade, levando em consideração a facilidade no acesso para seu público alvo, em destaque: as plataformas G Suite, Google Meet e Zoom. A ideia ao utilizar tais plataformas foi para minimizar a defasagem no processo de ensino-aprendizagem garantindo a continuação do mesmo, bem como da pesquisa e da extensão. Neste contexto, são poucas as Instituições que contam com plataformas direcionadas a um determinado conteúdo e que atende diretamente a demanda da ementa de cada disciplina, sendo o que de fato se propõe nesta tese com a plataforma "Embriologia comparativa" para as disciplinas de embriologia animal e afins, criando um espaço pedagógico e garantindo o aprendizado colaborativo centrado no estudante. Assim, a ideia trabalhada nesta tese vai, de acordo, aos descritos de Ferreira (2014) onde a perspectiva é propiciar autonomia aos estudantes e que estas sejam suficientes no momento da busca de conceitos e conhecimentos, assegurando a ética e a responsabilidade relacionada a transmissão dos saberes. 


\section{CONCLUSÃO}

Conclui-se que a presente tese se apresenta como um auxílio aos projetos pedagógicos dos cursos de graduação e pós-graduação que fazem uso da especialidade em ciências morfológicas, na perspectiva de mitigar as dificuldades encontradas no processo de ensino-aprendizagem das áreas de interesse. Acreditamos ainda que torna possível o ensino da embriologia de animais domésticos mediante a utilização de plataformas virtuais, cumprindo eficientemente com o propósito de oferecer meios aos discentes envolvidos no processo educacional a construção de um conhecimento comparativo inerente ao desenvolvimento dos animais.

Deste modo, o uso de recursos virtuais acerca da Embriologia comparativa e dos conhecimentos desde a fecundação até o nascimento, promove saberes referente as mudanças simultâneas macroscópicas que ocorrem no período de desenvolvimento dos animais sob todos os seus aspectos.

A partir disso, ressaltamos que a aquisição de materiais biológicos se torna cada vez mais dificultosa principalmente no que se refere o desenvolvimento completo dos animais. Tal ocorrência inclui o momento da coleta até a aplicação do conteúdo na sala de aula. Mesmo que haja materiais biológicos disponíveis, quando se tem um grande número de alunos (por ser um material delicado e minucioso) semestre após semestre se deterioram progressivamente, por isso, na maioria das vezes a prática é dada utilizando vidros com os espécimes amostrados pelo professor responsável. Com o uso de alternativas complementares por foto documentações, ilustrações e vídeos fidedignos é possível simplificar a práxis didática de maneira adequada e satisfatória. 


\section{REFERÊNCIAS}

ABREU, D. K.; RODRIGUES, E. A. F.; MONTEIRO, J. M.; FRANCIOLLI, A. L.; COSTOLA-SOUZA, C.; ROBALLO, K. C. S.; AMBRÓSIO, C. E. \& MIGLINO, M. A. Microscopic and macroscopic study focusing ray and alizarin on embryonic and fetal development in cats (Felis catus) in different gestational ages. Pesq. Vet. Bras. 31 (Supl.1):57-66, 2011.

ACKERMANN, P. The suitability of multimedia resource for teaching undergraduate histology in a developing country. Johannesburg: University of Pretoria. 265 p. Tese Doutorado. 2004.

ALBERTS, B.; BRAY, D.; HOPKIN, K.; JOHNSON, A.; LEWIS, J.; RAFF, M.; ROBERTS, K.; WALTER, P. Fundamentos da Biologia Celular, $2^{a}$ Edição, Editora ARTMED, 2006.

ALBERTO, M. L. V. Organogênese do aparelho respiratório e sistema cardiovascular de embriões bovinos provenientes de transferência nuclear e fertilização in vitro. [Organogenesis of the respiratory and cardiovascular system of bovine embryos derived from nuclear transfer and IVF]. 2010. 2012 f. Tese. Doutorado em Ciências - Faculdade de Medicina Veterinária e Zootecnia, Universidade de São Paulo, São Paulo, 2010.

ALEXPOULOS, N. I.; MADDOX-HYTTEL, P.; TERCILIOGLOU, R. T.; RUDDOCKD'CRUZ, N.; MADOX-HYTTEL, P. Stereomicroscopic and histological examination of bovine embryos following extend in vitro culture. Reproduction, Fertility and Development, v. 17, p. 799-808, 2005.

ALMEIDA, JORGE MAMEDE. Embriologia Veterinária Comparada. Editora Guanabara Koogan, 1999.

ANTÚNEZ, G. et al. Blended learning: una propuesta en actividades de postgrado en profesionales de las Ciencias Veterinarias. REDVET. Revista Electrónica de Veterinaria, v. 14, n. 4, p. 1-8, 2013.

ARTHUR, G. H. Reprodução e obstetrícia em veterinária. 4. ed. Rio de Janeiro: Guanabara Koogan; 573 p. 1979.

ASHWORTH, C. J.; PICKARD, A. R. Embryo survival and prolificacy. In: WISEMAN, J.; VARLEY, M. A. CHADWICK, J. P (Eds.). Progress in pig science. Nottingham: Nottingham University, p. 303-325, 1998. 
ASSUNÇÃO, M. P. B.; MIGLINO, M. A. Métodos Alternativos no Processo de EnsinoAprendizagem em Embriologia Comparativa: Desafios e Perspectivas. Revista de Graduação USP, vol. 4, n. 1 jul, 2020.

AZHAR, K. A.; IQBAL, N. Effectiveness of Google classroom: Teachers perceptions. Prizren Social Science Journal, v. 2, n. 2, p. 52-66, 2018.

BRUNSTRÖM, B.; REUTERGÅRDH, L. Differences in sensitivity of some avian species to the embryotoxicity of a PCB, 3,3',4,4'-tetrachlorobiphenyl, injected into the eggs. Environmental Pollution Series A, v.42, p.37-45, 1986.

BRUNSTRÖM, B. Sensitivity of embryos from duck, goose, herring gull, and various chicken breeds to 3,3',4,4'-tetrachlorobiphenyl. Poultry Science, v.67, p.52-57, 1988.

BRUNSTRÖM, B. Toxicity of coplanar polychlorinated biphenyls in avian embryos. Chemosphere, v.19, p.765-768, 1989.

BEAUDOIN, S.; BARBET, P.; BARGY, F. Developmental stages in the rabbit embryo: guidelines to hoose an appropriate experimental model. Fetal Diagnosis Therapy, $n$. 18, p. 422-427, 2003.

BAHLIS, Dos Santos, Nilton. Notas sobre a Educação à Distância e a Revolução Tecnológica. Revista Textos de la Ciber Sociedad, 6. Temática Variada. 2005. Disponível em: http://www.cibersociedad.net.

BALDO, Y. P. O modelo de planejamento para desenvolvimento de curso a distância: a experiência do CEFETE-ES. Instituto Federal Tecnológico do Espírito Santo Campus Serra. Serra, ES: maio de 2008.

BALINSKY, B. I. An Introduction to Embryology. Philadelphia: Saunders College Publishing. 768 p. 1981.

BARON, M. H. Embryonic origins of mammalian hematopoiesis. Experimental Hematology. vol. 31, n. 12, p. 1160-1169, New York, 2003.

BARRY, D. S. et. al., Anatomy education for the YouTube generation. Anatomical sciences education, v. 9, n. 1, p. 90-96, 2016.

BERNARDO, V. Web-based learning in undergraduate medical education: developmental and assessment of an online course on experimental surgery. International Journal of Medical Informatics, 73, p. 731-742, 2004. 
BRASIL. Lei no. 9.394, de 20 de dezembro de 1996. Estabelece as diretrizes e bases da educação nacional. Diário Oficial da República Federativa do Brasil, Brasília, DF, 23 dez. 1996.

BRASIL. Presidência da República. Lei № 11.794, de 8 de outubro de 2008. Regulamenta 0 inciso VII do parágrafo 1ำ do artigo 225 da Constituição Federal, estabelecendo procedimentos para o uso científico de animais; revoga a Lei ํo 6.638, de 8 de maio de 1979; e dá outras providências. [Internet]. Diário Oficial da União. 2008 [acesso 20 maio 2016]. Seção 1. Disponível: http://bit.ly/1WV52wP.

CAETANO-SIMÕES, J. C. O Papel das TIC na Produção Animal e Medicina Veterinária. REDVET. Revista electrónica de Veterinaria, v. 10, n. 2, p. 1-5, 2009. CAMPBELL, D. E. How to write good multiple-choice questions. Journal of paediatrics and child health, v. 47, n. 6, p. 322-325, 2011.

CARLSON, B. M. Embryology in the medical curriculum. The Anatomical Record, v. 269, n. 2, p. 89-98, 2002.

CARLSON, B. M. Human Embryology and Developmental Biology. 5. ed. Philadelphia: Elsevier Saunders, 2014. 506 p.

CARR, K. C.; FARLEY, C. L. Redesigning Courses for the World Wide Web. Journal of Midwifery \& Women's Health, Vol. 48, No. 6, p. 407 - 417, 2003.

CARVALHO, Y. K. $\mathbf{5 0 0}$ perguntas em Anatomia Animal - Animais Domésticos. Pará de Minas: VirtualBooks Editora, 2017.

CASAS, L.; AZEVEDO, R. CONTRIBUIÇÕES DO JOGO DIDÁTICO NO ENSINO DE EMBRIOLOGIA. Revista Areté | Revista Amazônica de Ensino de Ciências, [S.I.], v. 4, n. 6, p. 80-91, abr. 2017. ISSN 1984-7505. Disponível em: $<$ http://periodicos.uea.edu.br/index.php/arete/article/view/17>. Acesso em: 30 jun. 2020.

CHAIYO, Y.; NOKHAM, R. The effect of Kahoot, Quizizz and Google Forms on the student's perception in the classrooms response system. In: 2017 International Conference on Digital Arts, Media and Technology (ICDAMT). IEEE, 2017. p. 178182.

$\mathrm{CHOI}, \mathrm{K}$. The hemangioblast: a common progenitor of hematopoietic and endothelial cells. Journal of Hematotherapy \& Stem Cell Research. vol. 11, n. 1, p. 92-101, St Louis, 2002.

CHRISTIANSEN, I. J. Reprodução no cão e no gato. Ed. Manole. São Paulo. 79-83 p. 1998. 
CONCEIÇÃO, R. A.; AMBRÓSIO, C. E.; MARTINS, D. S.; CARVALHO, A. F.; FRANCIOLLI, A. L. R; MACHADO, M. R. F.; OLIVEIRA, M. F. \& MIGLINO, M. A. Aspectos morfológicos do saco vitelino em roedores da subordem Hystricomorpha: paca (Agouti paca) e cutia (Dasyprocta aguti). Pesq. Vet. Bras. 28:253-259. 2008.

CORNACCHIONE Jr.; Edgard B e SILVA Matheus da. Tecnologia da Educação: análises envolvendo experimentos a distância e presenças em disciplinas de cursos de Contabilidade. 2000.

CROWTHER, E.; BAILLIE, S. A method of developing and introducing case-based learning to a preclinical veterinary curriculum. Anatomical sciences education, v. 9, n. 1, p. 80-89, 2016.

CFMV. Dados da Comissão de Educação da Medicina Veterinária. Portal CFMV/CRMV's. Disponível em: http://portal.cfmv.gov.br. 2020.

DALE, V. H. M.; SULLIVAN, M.; MAY, S. A. Adult learning in veterinary education: theory to practice. Journal of veterinary medical education, v. 35 , n. 4, p. 581-588, 2008.

DAY, L. J. A gross anatomy flipped classroom effects performance, retention, and higher-level thinking in lower performing students. Anatomical sciences education, v. 11, n. 6 , p. 565-574, 2018.

DI DIO, L. J. A. Tratado de anatomia aplicada. vol. 2. São Paulo: Póluss, 2002.

DRAKE, R. L. A retrospective and prospective look at medical education in the United States: Trends shaping anatomical sciences education. Journal of anatomy, v. 224, n. 3, p. 256-260, 2014.

DUARTE, A. G. E. Desenvolvimento e avaliação de uma metodologia para o ensino de embriologia humana baseada em quizzes eletrônicos. 2007. 133f. Dissertação [Mestre em Biologia Celular e Estrutural, Área de concentração: Biologia Celular] Universidade Estadual de Campinas/UNICAMP, Campinas, São Paulo, 2007.

DYCE, K. M.; SACK, W. O.; WENSING, C. J. G. Tratado de Anatomia Veterinária. 5ed. Rio de Janeiro: Guanabara Koogan, 2010.

ERTMER, P. A.; NOUR, A. Y. M. Teaching basic medical sciences at a distance: strategies for effective teaching and learning in internet-based courses. Journal of veterinary medical education, v. 34, n. 3, p. 316-324, 2007. 
EVANS, H. E.; SACK, W. O. Prenatal development of domestic and laboratory mammals: growthcurves, external features and selected references. Anatomy, Histology and Embryology, v. 2, p. 11-45, 1973.

ENGWALL, M.; BRUNSTRÖM, B.; JAKOBSSON, E. Ethoxyresorufin O-deethylase $(E R O D)$ and aryl hydrocarbon hydroxylase $(\mathrm{AHH})$-inducing potency and lethality of chlorinated naphtalenes in chicken (Gallus domesticus) and eider duck (Somateria mollissima) embryos. Archives of Toxicology, v.68, p.37-42, 1994.

FERREIRA, A. S. S. B. S. Elaboração e avaliação de um ambiente virtual para o ensino/aprendizagem de Embriologia. Botucatu: UNESP, 2011. 90 p. Tese de Doutorado.

FERREIRA, J. M. M. Flipped classrooms: From concept to reality using Google Apps. In: 2014 11th International Conference on Remote Engineering and Virtual Instrumentation (REV). IEEE, 2014. p. 204-208.

FERREIRA, A. S. S. B. S.; KEMPINAS, W. de G. Avaliação de um ambiente virtual de ensino de apoio à educação presencial em curso de graduação em Biologia. In: CONGRESSO INTERNACIONAL DE EDUCAÇÃO A DISTÂNCIA, 16. Foz do Iguaçu, 2010. Anais. Foz do Iguaçu: Associação Brasileira de Educação a Distância, 2010. Acesso em: 30 abril 2019.

FLEAGLE, T. R. et al. Application of flipped classroom pedagogy to the human gross anatomy laboratory: Student preferences and learning outcomes. Anatomical sciences education, v. 11, n. 4, p. 385-396, 2018.

FLETCHER, T. F. E.; WEBER, A. F. Veterynary developmental anatomy, veterinary embryology. Minnesota: College of Veterynary Medicine University of innesota, 2004.

FORMENTIN, D.; CUPPER VIEIRA, C.; JOSE SUDANO, M.; SILVEIRA MESQUITA, F. Elaboração de modelos didáticos da embriogênese para a disciplina de embriologia e histologia animal I. Anais do Salão Internacional de Ensino, Pesquisa e Extensão, v. 7, n. 1, 12 fev. 2020.

FRANCIOLLI, A. L. R. Medicina veterinária regenerativa: multipotencialidade das células da membrana amniótica e do saco vitelino no modelo equino (Equus caballus, Linnaeus 1758). [Veterinary regenerative medicine: multipotential of the cells amniotic membrane and yolk sac the model horse (Equus caballus, Linnaeus 1758)]. 2012. 191f. Tese (Doutorado em Ciências) - Faculdade de Medicina Veterinária e Zootecnia, Universidade de São Paulo, 2012.

FREIRE, T. Estilos de aprendizagem e o autodesenvolvimento. Manifesto 55, 2018. Disponível em: https://oer.kmi.open.ac.uk/wp-content/uploads/2012/04/fig4.jpg 
GONZALES, E. Embriologia e Desenvolvimento Embrionário. In: APINCO. Manejo da Incubação. São Paulo, 1994.

GAldos, A. C. R.; REZENDE, L. C.; PESSOlAtO, A. G. T.; MiGlinO, M. A. A relação biológica entre saco vitelino e o embrião. Enciclopédia biosfera, Centro cientifico conhecer? Goiânia, v. 6. n. 11, p. 12-21, 2010.

GARCIA, S. M. L; FERNANDEZ, C. G. Embriologia. 2 a ed. SP: ArtMed, 2001.

GILBERT, S. F. Biologia do Desenvolvimento, 2a Edição revisada, 1995.

GILBERT, S. F. Developmental Biology. 8th ed. Sinauer Associates. 814p. 2006.

GILBERT, S. F. Developmental Biology. Massachusetts: Sinauer, 2000; 2001. 749 p.

GILBERT, S. F. The morphogenesis of evolutionary developmental biology. International Journal of Developmental Biology. 47: 467-477. 2003.

GINTHER, O. J. Reproductive biology of the mare - Basic and applied aspects. Chapter: 9, "Placentation and Embryology", United States - USA, pág. 255-320, 1979.

GROSS, B. C. et al. Evaluation of 3D printing and its potential impact on biotechnology and the chemical sciences. Analytical Chemistry, v. 86, n. 7, p. 3240-3253, 2014.

GUIMARÃES, M. V.; FREIRE, J. E. C.; MENEZES, L. M. B. Utilização de animais em pesquisas: breve revisão da legislação no Brasil. Rev. bioét. (Impr.). 24 (2): 217-24. 2016.

HAFEZ, E. S. E. Reprodução animal. 4. ed. Barueri: Manole, 720 p. 1982.

HAFEZ, E. S. E.; HAFEZ, B. Reprodução Animal. 7ª ed. São Paulo: Manole, 513p, 2004.

HALL, B. K. Evolutionary Developmental Biology. Chapman e Hall Suffolk. 275p. 1992.

HAMBURGER, V.; HAMILTON, H. L. A series of normal stages in the development of the chick embryo. Developmental Dynamics., 195,231-72.1951. 
HECKLER, V.; SARAIVA, M. d. F. O.; FILHO, K. d. S. O. Uso de simuladores, imagens e animações como ferramentas auxiliares no ensino/aprendizagem de óptica. SciELO Brasil, 2007.

HEIDGER, P. M.; DEE, F.; CONSOER, D.; LEAVEN, T.; DUNCAN, J.; KREITER, C. Integrated Approach to Teaching and Testing in Histology With Real And Virtual Imaging. Anatomical Record. v. 269, p. 107-112, 2002.

HILDEBRAND, M. Análise da Estrutura dos Vertebrados. São Paulo: Atheneu, 1995.

HILL, M. A. Embryology Book - A Laboratory Manual and Text book of Embryology 3. Acesso em: 04 de julho de 2020. Disponível em: https://embryology.med.unsw.edu.au/embryology/index.php/Book A Laboratory Ma nual and Text-book of Embryology 3

HOUILLON, C. Embriologia. São Paulo: Edgar Blücher, 1972. 160 p.

HUDSON, J. N.; BRISTOW, D. R. Formative assessment can be fun as well as educational. Advances in Physiology Education, v. 30, p. 33-37, 2006.

HYTTEL, P. Development of the blood cells, heart and vascular system. In: HYTTEL, P.; SINOWATZ, F.; VEJLSTED, M. Essential of domestic animal embryology. Edinburgh, London, New York, Oxford, Philadelphia, St Louis, Sydney, Toronto: Elsevier, 2010. 455p

HYTTEL, P.; CARLSSON, G. L.; SCOTT, HELLER, R. \& SERUP, P. Immunohistochemistry of Pancreatic Development in Cattle and Pig. Anat. Histol. Embryol. 39(2):107-119. 2009.

HYTTEL, P.; SINOWATZ, F. \& VEJSTED, M. Domestic Animal Embryology. 11th ed. Saunders, Elsevier, p.359. 2010.

HAYASHI, A. et al. The role of social presence and moderating role of computer self efficacy in predicting the continuance usage of e-learning systems. Journal of Information Systems Education, v. 15, n. 2, p. 5, 2020.

HEYMANN, D. L.; SHINDO, N. COVID-19: what is next for public health?. The Lancet, v. 395, n. 10224, p. 542-545, 2020.

ILLANES, J. et. al. Análisis Macroscópico y Microscópico Del Desarrollo Embrionario y Fetal em el Gato (Felis catus), en Relación con El Desarrollo de la Vesícula Coriónica y de la Placenta. Internacional Journal of Morphology, v.25, n.3, p. 467-481, 2007. 
JI, R. P.; PHOON, C. K.; ARISTIZABAL, O.; MCGRATH, K. E.; PALIS, J.; TURNBULL, D. H. Onset of cardiac function during early mouse embryogenesis coincides with entry of primitive erythroblasts into the embryo proper. Circulation Research. vol. 92, n 2, p. 133-135, New York, 2003.

JOTTA, L. Embriologia animal: uma análise dos livros didáticos de Biologia do Ensino Médio. 2005. 244 f. Tese (Doutorado) - Dissertação (Mestrado em Educação) - Faculdade de educação da Universidade de Brasília, Brasília, 2005.

JUSTINO, M. L. Estratégias para uso de um software de ensino de embriologia humana: utilização e avaliação. Dissertação (Mestrado) - Universidade Estadual de Campinas. Campinas, SP: [s.n.], 2013.

KNOSPE, C. Periods and stages of the prenatal development of the domestic cat. Anatomy, Histology and Embryology, n. 31, p. 37-51, 2002.

KASEMSAP, K. The Role of Distance Education in Global Education. In: Advanced Methodologies and Technologies in Modern Education Delivery. IGI Global, 2019. p. 865-877.

KERR, A. J.; MULLAN, S. M.; MAIN, D. C. J. A new educational resource to improve veterinary students' animal welfare learning experience. Journal of veterinary medical education, v. 40, n. 4, p. 342-348, 2013.

KOLB, D. A. Experiential learning: Experience as the source of learning and development. FT press, 2014.

KOZLU, T. AKADYDIN-BOZKURT, Y. ATES, S. A macroanatomical and histological study of the uropygial gland in the white stork (Ciconia cicionia). Int $J$ Morphol 29:723726. 2011.

KRONTIRIS-LITOWITZ, J. Using manipulatives to improve learning in the undergraduate neurophysiology curriculum. Advances in physiology education, Am Physiological Soc, v. 27, n. 3, p. 109-119, 2003.

LEISER, R.; KAUFMANN, P. Placental structure: in a comparative aspect. Experimental/Clinical Endocrinology. vol. 102, n. 2, p. 122-134, Giessen, 1994.

MACDONALD, J. Blended learning and online tutoring: Planning learner support and activity design. Gower Publishing, Ltd., 2008.

MADDOX-HYTTEL, P.; ALEXPOULOS, N. I.; VAJTA, G.; LEWIS, I.; ROGERS, P.; CANN, L.; CALLESEN, H.; TVEDEN-NYBORG, P.; TROUNSON, A. 
Imunohistochemical and ultrastructural characterization of the initial post-hatching development of bovine embryos. Reproduction, v. 125, p. 607-623. 2003.

MAIA, N. R. F.; DA SILVA, M. V. L.; CAVALCANTE, C. A. M.; MONTEIRO, F. A. C.; CATUNDA, A. G. V. Animações virtuais como proposta metodológica para o ensino de embriologia. Conex. Ci. e Tecnol. Fortaleza/CE, v.11, n. 6, p. 17 - 26, dez. 2017.

MASSARI, C. H. A. L. et al. Tendências do Ensino de Anatomia Animal na Graduação de Medicina Veterinária. Revista de Graduação USP, v. 3, n. 2, p. 25-32, 2018.

MCGRATH, K. E.; PALIS, J. Hematopoiesis in the yolk sac: more than meets the eye. Experimental Hematology, vol. 33, n. 9, p. 1021-1028, Rochester, 2005.

MENEZES D. J. A.; CARVALHO, M. A. M.; CAVALCANTE FILHO, M. F. \& SOUZA, W. M. Configuração do sistema venoso portal na cutia (Dasypocta agouti, Rodentia). Braz. J. Vet. Res. Anim. Sci. 38:263-266. 2001.

MIGLINO, M. A. Pesquisa anatômica sobre a ramificação e distribuição das artérias e veias da placenta de bovinos. 1991.303 p. Tese (Livre docência) Faculdade de Medicina Veterinária e Zootecnia, Universidade de São Paulo, São Paulo, 1991.

MINISTÉRIO DA EDUCAÇÃO. Portaria no 2.117, de 6 de dezembro de 2019. Dispõe sobre a oferta de carga horária na modalidade de Ensino a Distância - EaD em cursos de graduação presenciais ofertados por Instituições de Educação Superior - IES pertencentes ao Sistema Federal de Ensino. 2019.

MONTANARI, T. Dispositivos móveis e modelagem no ensino de Embriologia. Novas tecnologias na educação / CINTED-UFRGS, v. 15, n. 2, 2017.

MOORE, K. L.; PERSAUD, T.V.N. Embriologia Clínica. 5ae ed. São Paulo: Guanabara Koogan, 1994.

MOORE, K.; PERSAUD, T. V. N. Embriologia Básica. 8ed. São Paulo: Elsevier, 2008. 462p.

MORAES, S. G.; MUNIZ, A. L. Utilização de modelos 3D como recurso didático no ensino de embriologia do sistema nervoso central. Revista da Faculdade de Ciências Médicas de Sorocaba, [S.I.], nov. 2018. ISSN 1984-4840. Disponível em: $<$ https://revistas.pucsp.br/RFCMS/article/view/40101>. Acesso em: 01 jul. 2020.

MORAES, S. G.; PEREIRA, L. A. V. D. A multimedia approach for teaching human embryology: Development and evaluation of a methodology. Annals of Anatomy, v. 192, p. 388-395, 2010. 
MORAES, S. G.; REIS, M. V. A; MELLO, M. F. S.; PEREIRA, L.A.V. The usefulness of autopsies as a tool for teaching human embryology. Brazilian Journal of Morphological Sciences, v. 21, n.3, p. 117-123, 2004. Disponível em: <http://libdigi.unicamp.br/document/?view=10004>. Acesso em: 01 fev. 2019.

MORAES, S.G. Desenvolvimento e avaliação de uma metodologia para o ensino de embriologia humana. Campinas, São Paulo. 2005. 309f. Tese [Doutor em Biologia Celular e Estrutural, Área de concentração: Histologia] - Universidade Estadual de Campinas/UNICAMP, Campinas, São Paulo, 2005.

MORAN, J. M. A Educação que desejamos: novos desafios e como chegar lá. 4 ed. Campinas, SP: Papirus, 2007.

MORAN, J. M. Mudar a forma de ensinar e de aprender com tecnologias. Transformar as aulas em pesquisa e comunicação presencial-virtual. Acesso em 29/04/2019.

MORAN, José Manuel, Marcos T. Masetto, Marilda Aparecida Behrens. Novas tecnologias e mediação pedagógica. Campinas, SP: Papirus, 2000.

MOREIRA, M. A. A teoria da aprendizagem significativa e sua implementação em sala de aula. Brasília: Editora Universidade de Brasília, 2006.

NASCIMENTO. Uma experiência de integração do ambiente de aprendizagem Moodle com software de gestão acadêmico - Q-Acadêmico. In: 14ํㅡㄹ Congresso Internacional de Educação a Distância. Santos - SP, 2008.

NELSEN, O. E. Comparative embryology of the vertebrates. New York, Toronto, London: McGrall-Hill, 1953. 489p.

NEVES, Carlos. Caia na rede. Revista T \& D. Maio 2000. Ano VIII. Edição89. P. 3639.

NODEN, D. N. \& LAHUNTA, A.; Embriologia de los animales Domésticos; ed. Acribia, 1991; cap. 1, 2 e 3.

OLIVEIRA, N. M. de; JúNIOR, W. D. O uso do vídeo como ferramenta de ensino aplicada em biologia celular. 2012.

OLIVEIRA, M.S.; VASCONCELOS, Y.A.G.; MELO-MACIEL, M.A.P.; LEITE, L.V.; LINHARES, F.R.A.; NUNES, L.T.; SALMITO-VANDERLEY, C.S.B.; PINHEIRO, J.P.S. Elaboração de um glossário ilustrado de embriologia animal comparada. Resumos Expandidos do I CONICBIO / II CONABIO / VI SIMCBIO. Universidade Católica de Pernambuco - Recife, v. 2, 2013. 
PALIS, J.; YODER, M. C. Yolk-sac hematopoiesis: the first blood cells of mouse and man. Experimental Hematology. vol. 29, n. 8, p. 927-936, Rochester, 2001.

PRIVES, M.; LISENKOV, N.; BUSHKOVICH. V. Anatomia humana. Tomo I. 5. ed. Moscou; NIR, 1984. 218p.

PUIG, W. R.; BORJAS, C. D.; TORRES, I. A. Morfologia humana. Tomo I. La Habana: Editorial Ciências Médicas, 2002.

RAMADHANI, R. et al. The effect of flipped-problem based learning model integrated with LMS-google classroom for senior high school students. Journal for the Education of Gifted Young Scientists, v. 7, n. 2, p. 137-158, 2019.

RICHARDSON, M. K. \& KEUCK, G. Haeckel's ABC of evolution and development. Biological Reviews. 77:495-528. 2002.

RICHARDSON, M. K.; GOBES, S. M. H.; VAN LEEUWEN, A. C.; POLMAN, A. E.; PIEAU, C.; SANCHEZ-VILLAGRA, M. Heterochrony in limb evolution: developmental mechanisms and natural selection. Journal of Experimental Zoology (Mol. Dev Evol). 312B: 1-26. 1999.

RODRIGUES, A. L. M.; FIEDLER, P. T.; SANTOS, S. H. P. D.; PEROTA, B.; HIROSE, T. E.; OLIVEIRA, S. A. D.; SATO, M. H.; ÁVILA, H. S.; MORAES, T. C. D. ; FERREIRA, F. D. F. I. Embriologia prática - uma lição diferente. Arquivos da Apadec, Maringá, v. 8, supl. 2, p. 11, out. 2004.

RODRIGUEZ-MORALES, A. J. et al. COVID-19 in Latin America: The implications of the first confirmed case in Brazil. Travel Medicine and Infectious Disease, v. 101613, 2020.

ROJAS, M.; CUEVAS, F.; SMOK, C.; ROA, I.; CONEI, D.; PRIETO, R. \& DEL SOL, M. ¡Estudiando el desarrollo embrionário y fetal con el microscopio virtual! En tiempos de covid-19. Int. J. Morphol., 38(5):1296-1301, 2020.

ROLFE, I.; MCPHERSON, J. Formative assessment: How am I doing? Lancet, v. 345, p. 837-839, 1995.

ROXO, M. L. R. A importância da interação digital em EAD para a criação de estratégias de ensino. Rev. Cesuca virtual: conhecimento sem fronteiras. Cachoeirinha RS. v.2, n. 3. 2015. 
SCHOENWOLF, G. C. The avian embryo: a model for descriptive and experimental embryology. In: MOODY, S. A. Cell lineage and fate determination. San Diego: Academic Press, 644p, 1999.

SADLER, T. W. Langman Embriologia Médica. 9ª ed. Guanabara Koogan, Rio de Janeiro, p.3-77, 2005.

SADLER, T. W. Langman Embriologia Médica. Tradução da 11ạ Edição. Editora Koogan, 2010.

SAMAR, M. E.; AVILA, R. E. Materiales instruccionales en la enseñanza virtual de la histologia y embriologia humana. In: CONGRESO VIRTUAL HISPANOAMERICANO DE ANATOMÍA PATOLÓGICA, 9. y CONGRESSO DE PREPARACIONES VIRTUALES POR INTERNET, 2., 2007, Ciudad Real. Anais. Ciudad Real: Universidad de Castilla La Mancha y Complejo Hospitalario de Ciudad Real. 2007.

SANDRONE, S. et al. Strategic considerations for applying the flipped classroom to neurology education. Annals of Neurology, v. 87, n. 1, p. 4-9, 2020.

SANTA-ROSA, J. G.; STRUCHINER, M. Tecnologia educacional no contexto do ensino de Histologia: pesquisa e desenvolvimento de um ambiente virtual de ensino e aprendizagem. Revista Brasileira de Educação Médica, v. 35, n. 2, p. 289-298, 2011.

SHARP, D. C. The early fetal life of the equine conceptus. Animal Reproduction Science. vol. 60, n. 61, p. 669-679, Gainesville, 2000.

SHORT, N. The use of information and communication technology in veterinary education. Research in Veterinary Science, v. 72, n. 1, p. 1-6, 2002.

SILVEIRA, S. R.; IDERIHA, N. M. Uso de modelo tridimensional de argila no Ensinoaprendizagem de Embriologia Humana. Anais do I Seminário UNESC de Humanidades Médicas, Colatina - ES, 2013.

SLACK, J. M. W.; HOLLAND, P. W. H.; GRAHM, C. F. The zootype and the phylotypic stage. Nature. 1993. 361:490-492.

STORER, T. I.; USINGER, R. L.; STEBBINS, R. C. NYBAKKEN, J. W. Zoologia Geral. Companhia Editora Nacional: São Paulo, 1989.

THOMAS, D. B. et al. 3D scanning and printing skeletal tissues for anatomy education. Journal of anatomy, v. 229, n. 3, p. 473-481, 2016. 
THOMAS, D. B.; FORDYCE, R. E. Biological plasticity in penguin heat-retention structures. The Anatomical Record: Advances in Integrative Anatomy and Evolutionary Biology, v. 295, n. 2, p. 249-256, 2012.

TIEDEMANN, K.; MINUTH, W.W. The pig yolk sac I. Histochemistry. vol. 68, n. 2, p. 133-146, Heidelberg, 1980a.

VAHALIA, K. V. et al. The use of multiple-choice tests in anatomy: Common pitfalls and how to avoid them. Clinical Anatomy: The Official Journal of the American Association of Clinical Anatomists and the British Association of Clinical Anatomists, v. 8, n. 1, p. 61-65, 1995.

VEJLSTED, M. Gatrulation. Body folding and coelon formation. In: HYTTEL, P.; SINOWATZ, F.; VEJLSTED, M. Essential of domestic animal embryology. Edinburgh, London, New York, Oxford, Philadelphia, St Louis, Sydney, Toronto: Elsevier, 2010. 455p

WALLS, J. R.; COULTAS, L.; ROSSANT, J.; HENKELMAN, M. Three-dimensional analysis of vascular development in the mouse embryo. Plos one. vol. 3, n. 8 e2853, Toronto, 2008.

WILMUT, I.; RITCHIE, W. A.; HALEY, C. S.; ASHWORTH, C. J.; AITKEN, R. P. A. Comparison os rate and uniformity of embryo development in Meishn and European white pigs. Journal of Reproduction and Fertility, v. 95, p. 45-56, 1992.

WINTERS, L. M.; GREEN, W. M.; CONSTOCK, R. E. Prenatal development of the bovine. Agriculture Experimental Sta Minesota, v. 50, p. 1-50, 1942.

WOLPERT, L.; BEDDINGTON, R.; BROCKES, J.; JESSEL, T.; LAWRENCE, P.; MEYEROWITZ, E. Principles of Development. NY: Oxford University Press, 345p. 1998.

WOLPERT, L.; BEDDINGTON, R.; BROCKES, J.; JESSEL, T.; LAWRENCE, P.; MEYEROWITZ, E. Princípios de Biologia do Desenvolvimento, editora ARTMED, 2000.

XINHUANET. The Ministry of Education of the People's Republic of China interprets "China Education Modernization 2035" and its implementation plan (2018-2022). Http://www.chinanews.com/gn/2019/02-23/8762909.shtml,02-23/2020-03-11, 2019.

XU, M. J.; MATSUOKA, S.; YANG, F. C.; EBIHARA, Y.; MANABE, A.; TANAKA, R. Evidence for the presence of murine primitive megakaryocytopoiesis in the early yolk sac. Blood. vol. 97, n. 7, p. 2016-2022, Tokyo, 2001. 
YAMMINE, K.; VIOLATO, C. A meta-analysis of the educational effectiveness of threedimensional visualization technologies in teaching anatomy. Anatomical sciences education, v. 8, n. 6, p. 525-538, 2015.

ZHOU, L. et al. 'School"s Out, But Class" On', The Largest Online Education in the World Today: Taking China"s Practical Exploration During The COVID-19 Epidemic Prevention and Control As an Example, (March 15, 2020). Best Evidence of Chinese Education, v. 4, n. 2, p. 501-519. 2020. 
APÊNDICES 


\section{APÊNDICE A - Avaliação Inicial e Avaliação Final}

$18 / 11 / 2020$

AVALIAÇÃO INICIAL

\section{AVALIAÇÃO INICIAL}

Olá!

Este questionário tem como objetivo avaliar seus conhecimentos prévios acerca da embriologia animal, ou seja, os saberes e as informações que você já possui em mente antes de ter acesso aos conteúdos disponíveis na plataforma.

*Obrigatório

1. NOME COMPLETO *

2. E-MAIL *

3. IDADE *

Marcar apenas uma oval.
$21-30$ anos
$31-40$ anos
41-50 anos
51-60 anos
Acima de 60 anos

4. $\mathrm{CPF} *$ 


\section{TERMO DE CONSENTIMENTO LIVRE E ESCLARECIDO}

Você está sendo convidado(a) como voluntário(a) a participar da pesquisa Plataforma digital: método alternativo de ensino-aprendizagem da embriologia comparativa com foco no sistema cardiovascular. A justificativa, os objetivos e os procedimentos: 0 motivo que nos leva a estudar a implantação da plataforma, uma plataforma educacional de Embriologia Comparativa é, ao final desta experiência, investigar a aquisição de conhecimentos científico pelos estudantes dos cursos de Ciências Biológicas, Medicina Veterinária e afins. A pesquisa se justifica pela necessidade de contribuir para a educação, aprimorando o uso de métodos alternativos no processo de ensino-aprendizagem da embriologia. O objetivo desse projeto é investigar o impacto da implantação da plataforma virtual sobre os alunos. Os procedimentos de coleta de dados ocorrerão da seguinte forma: três questionários serão disponibilizados individualmente aos estudantes para serem respondidos, sendo uma enquete inicial, uma avaliação final e uma pesquisa de satisfação. Desconfortos e riscos e benefícios: Não existe qualque desconforto ou risco mínimo para que você se submeta à coleta de dados quais serão analisados exclusivamente pelo pesquisador (docente responsável). Tal coleta justifica-se pela necessidade de avaliar o que os estudantes aprenderam por meio do método virtual de ensino, para que, em conjunto, possamos melhorar sua aplicação no futuro discutindo seus alcances e suas limitações. Garantia de esclarecimento, liberdade de recusa e garantia de sigilo: Você será esclarecido(a) sobre a pesquisa em qualquer aspecto que desejar. Você é livre para recusar em participar, retirar seu consentimento ou interromper a participação a qualquer momento. A sua participação é voluntária e a recusa em participar não irá acarretar qualquer penalidade ou perda de benefícios. 0 pesquisador irá tratar a sua identidade com padrões profissionais de sigilo. Os resultados dos questionários serão enviados para você e permanecerão confidenciais. Seu nome ou o material que indique a sua participação não será liberado sem a sua permissão. Você não será identificado(a) em nenhuma publicação que possa resultar deste estudo. Uma cópia deste consentimento informado será arquivada com o pesquisador e outra será fornecida a você. Custos da participação, ressarcimento e indenização por eventuais danos: A participação no estudo não acarretará custos para você, bem como não será disponível nenhuma compensação financeira adicional. Afirmo que fui informada (o) dos objetivos da pesquisa acima de maneira clara e detalhada e esclareci minhas dúvidas. Sei que em qualque momento poderei solicitar novas informações e motivar minha decisão se assim o desejar. Contudo, autorizo publicação das minhas respostas tanto na tese do doutorando Marcos Paulo Batista de Assunção quanto em artigos científicos que vierem a ser publicados. Por fim, eu aceito participar voluntariamente desse estudo. Declaro, portanto, concordar com o referido termo.

5. 1) 0 que você entende por Embriologia? Assinale uma das alternativas abaixo: *

\section{Marcar apenas uma oval.}

É o estudo que visa decifrar a influência dos astros no curso dos acontecimentos terrestres, na vida das pessoas e em seu destino.

É uma área da Ciências Biológicas que estuda o desenvolvimento embrionário dos mais diferentes organismos vivos, ou seja, o processo de formação do embrião a partir de uma única célula, o zigoto, que originará um novo ser vivo.

É a ciência do Homem que engloba origens, evolução, cultura, psicologia, costumes sociais e crenças.

É a ciência que trata do universo sideral e dos corpos celestes, com a finalidade de situá-los no espaço e no tempo e explicar sua origem e seu movimento.

É a totalidade das ciências, técnicas e conhecimentos que regem a prática da agricultura. 
6. 2) 0 conhecimento acerca da embriologia é importante para que um indivíduo se torne um(a) bom(a) biólogo(a), médico(a) veterinário(a)? Se sim, liste em seguida os argumentos que apoiam sua opinião. *

7. 3) 0 estudo morfológico a olho nu apresentou-se como o primeiro método de estudo do desenvolvimento embrionário, para tanto, mais tarde com o advento de novas tecnologias foi possível observações mais detalhadas e minuciosas dos seres em desenvolvimento. A partir desta afirmação, cite o principal instrumento que permitiu tal ocorrência. *

8. 4) Quais das espécies de animais domésticos Aristóteles descreveu o desenvolvimento embrionário? * 
9. 5) A nutrição fetal em bovinos por exemplo, se dá por meio da placenta e do cordão umbilical. Se não, justifique sua resposta. *

10. 6) 0 que você entende por gametogênese?*

11. 7) Qual o evento fundamental da gametogênese? * 
12. 8) Mediante a fusão de dois gametas haploides, reconstitui-se o número diploide característico para cada espécie doméstica. Para tanto, o número de cromossomos apresenta-se em diferentes quantidades entre os animais, nas aves (Gallus gallus domesticus) e nos caninos (Canis lupus familiaris) o número de cromossomos é igual a: *

\section{Marcar apenas uma oval.}
78 cromossomos
38 cromossomos
64 cromossomos
60 cromossomos
90 cromossomos

13. 9) As células germinativas primordiais são tipos celulares somáticos. Quais das estruturas fundamentais para o progresso do desenvolvimento as CGPs dão origem? *

14. 10) Considerando os aspectos do desenvolvimento embrionário animal, podemos afirmar que: * Marcar apenas uma oval.

Seu início se dá com a divisão mitótica do zigoto, ou seja, a gastrulação.

A mórula representa um aglomerado de células com uma cavidade central.

A fase de segmentação culminará com a formação da blástula.

A gástrula se caracteriza pela presença de um único folheto germinativo, o ectoderma.

A diferenciação de tecidos e órgãos antecede a fase de gastrulação. 
15. 11) Sobre embriologia dos animais domésticos, assinale a alternativa correta. *

\section{Marcar apenas uma oval.}

A ectoderme dará origem à epiderme e seus anexos (pelos, glândulas, etc.), à derme e aos sistemas nervoso e muscular.

Durante o estágio de nêurula, no dorso do embrião dos cordados, a ectoderme forma um sulco que se aprofunda, originando a notocorda que persiste até a vida adulta dando suporte ao tubo nervoso.

Durante a gastrulação são observados os primeiros tecidos embrionários: a ectoderme, a endoderme e a mesoderme.

As células iniciais do embrião são denominadas de blastômeros. Após sucessivas clivagens dessas células, o embrião adquire a forma de uma estrutura maciça de células, a mórula.

Na fase de blástula, ocorre o aparecimento de uma cavidade cheia de líquido no interior da estrutura, a blastocele, e a camada de células que a delimita é a blastoderme.

16. 12) Após aproximadamente 30 horas da fecundação, o ovo inicia a primeira divisão, dando origem a dois blastômeros. Entre o terceiro e o quarto dia após a fecundação, o embrião apresenta-se no estágio de mórula. Em seguida, forma-se a blástula, também chamada de blastocisto. 0 texto em questão referese à blástula que aparece em: *

\section{Marcar apenas uma oval}

Embriologia de peixes

Embriologia de répteis

Embriologia de anfíbios

Embriologia de mamíferos

Embriologia de aves 
17. 13) A respeito dos anexos embrionários, assinale a alternativa abaixo que melhor representa a função das estruturas presentes no desenvolvimento. *

\section{Marcar apenas uma oval.}

O saco vitelínico é uma bolsa que abriga o vitelo e que participa no processo de nutrição do embrião, sendo bem desenvolvido nas aves (Gallus gallus domesticus), por exemplo.

O âmnio é uma membrana que envolve o embrião, delimitando a cavidade amniótica, que contém o líquido amniótico, cuja principal função é a de proteger o embrião contra choque mecânico e dessecação.

0 alantoide é um anexo que deriva da porção posterior do intestino do embrião, tendo como função, nos répteis e nas aves, armazenar excretas nitrogenadas e participar das trocas gasosas.

A placenta é uma estrutura embrionária formada pela interação entre tecidos materno-fetal.

O córion é uma membrana que envolve o embrião e todos os demais anexos embrionários. É o anexo embrionário mais externo e, nos ovos de répteis e aves, fica sob a casca, participando das trocas gasosas entre o embrião e o meio.

18. 14) No desenvolvimento embrionário dos animais, os folhetos germinativos (ectoderma, mesoderma e endoderma) são formados no decorrer da: *

Marcar apenas uma oval.

Espermatogênese

Clivagem

Organogênese

Gastrulação

Mórula 
19. 15) Analise cada proposição em relação ao processo de embriogênese e assinale a(s) correta(s). *

\section{Marcar apenas uma oval.}

A fecundação é a união entre os gametas do macho e da fêmea, que são haploides, para formar um zigoto (diploide).

Quando vários espermatozoides se aproximam do óvulo, ocorre o processo chamado de ativação.

A monospermia ocorre quando o espermatozoide é formado por apenas um flagelo.

A anfimixia consiste na formação do tubo polínico nas plantas superiores.

A partenogênese é o desenvolvimento de um embrião sem fecundação do óvulo pelo espermatozoide. Esse processo ocorre, por exemplo, nas abelhas.

20. 16) Preencha o texto a seguir, de acordo com uma das alternativas apresentas nas opções. "A primeira fase do desenvolvimento embrionário dos mamíferos, ou seja, ovo é a fase de onde no zigoto ocorrem consecutivas em que as células filhas dividem entre si o vitelo da célula mãe. A denominação das células resultantes das primeiras divisões celulares do embrião é conhecida como blastômeros. A célula ovo (ou zigoto) é transformado em uma massa compactade células denominada que passa a envolver uma cavidade interna cheia de líquido, conhecida como "Assinale o alternativa que melhor representa a sequência correta de palavras que completam o texto acima. *

\section{Marcar apenas uma oval.}

oligolécito; clivagem; mitoses; mórula; blástula

megalécito; gastrulação; meioses; mórula; gástrula

oligolécito; gastrulação; meioses; mórula; gástrula

megalécito; clivagem; mitoses; mórula; blástula

oligolécito; clivagem; meioses; blástula; mórula 
21. 17) Com relação ao desenvolvimento embrionário dos animais domésticos, assinale apenas a alternativa correta. *

\section{Marcar apenas uma oval.}

Um indivíduo que apresenta má formação congênita da medula espinal pode ocasionalmente gerar problemas no desenvolvimento da endoderme.

Os folhetos germinativos são: ectoderma, mesoderma e endoderma.

No decorrer do desenvolvimento embrionário as células sofrem o processo de diferenciação celular, resultando em um tecido com distintas funções.

As espécies que o blastóporo origina à boca são denominados de deuterostômios, e as que o blastóporo origina o ânus são os protostômios.

São duas as fases da gastrulação, a saber: a mórula e a blástula.

22. 18) No embrião felino (Felis catus), por exemplo, a fase de flexão ganha uma parte do saco vitelínico onde encontra-se incorporado no corpo embrionário. Esta porção deve desenvolver: *

\section{Marcar apenas uma oval}

A bolsa amniótica que protege o embrião em seu desenvolvimento.

A notocorda que induz a formação da coluna vertebral e costelas.

0 tubo neural que dá origem ao sistema nervoso central e periférico.

A cadeia de somitos que participam da formação musculoesquelético.

0 intestino primitivo que forma o forro mucoso tanto do sistema digestório quanto do sistema respiratório. 
23. 19) Das alternativas listadas abaixo, qual delas são exemplos de animais domésticos e que apresentam ovos ricos em vitelo (ou gema)? *

Marcar apenas uma oval.
Galinhas
Borboletas
Estrelas-do-mar
Tartarugas
Anfioxos

24. 20) Levando em consideração o desenvolvimento tanto anatômico quanto funcional das membranas extraembrionárias dos mamíferos placentários, a estrutura que apresenta menores modificações nesta classe de animais é: *

Marcar apenas uma oval.
A casca do ovo
o âmnio
0 córion
$\mathrm{O}$ alantoide
O saco vitelínico

25. 21) 0 primeiro estágio de células indiferenciadas que se formam no desenvolvimento embrionário dos animais é denominado de: *

Marcar apenas uma oval.

Blastômeros
Epigênese
Nêurula
Gástrula
Mórula


26. 22) Das alternativas listadas abaixo, no que diz respeito a corona radiata, assinale a opção correta: *

Marcar apenas uma oval.

Camada de células do cumulus, formadas a partir das células foliculares derivadas do ovário.

Estrutura multinucleada resultante da fusão de várias células.

Ponto de contato entre membranas de células adjacentes.

Camada de glicoproteínas que envolve o óvulo e confere aos gametas da fêmea uma alta especificidade.

Camada externa do embrião da qual se origina parte da placenta.

27. 23) Cite as 7 principais fases do desenvolvimento embrionário em ordem cronológica. *

28. 24) É correto afirmar que a embriologia comparativa estuda a formação e o desenvolvimento de embriões dos diferentes grupos do reino animal que fazem parte da escala zoológica e estabelece de forma comparativa os aspectos macro e microscópicos das mesmas estruturas das mais diferentes espécies? Se não, justifique sua resposta. * 
29. 25) A espermatogênese é o evento fundamental e responsável pelo o desenvolvimento das espermatogônias. A partir desta afirmação, das opções listadas abaixo, onde ocorre tal evento? * Marcar apenas uma oval.
$\mathrm{Na}$ bolsa escrotal
Nos túbulos seminíferos
Nos espermatozoides
Na tuba uterina
Na região de ampola da tuba uterina

30. 26) A ovogênese permite o desenvolvimento dos(as): *
Marcar apenas uma oval.
Folículos primordiais
Células germinativas
Células foliculares
Espermatogônias
Espermatócitos

31. 27) Das alternativas abaixo, qual compreende a duração e o tipo do ciclo reprodutivo de cadelas? * Marcar apenas uma oval.
6 meses, ovariano
21 dias, estral
6 meses, estral
25-26 horas, ovariano
14 a 21 dias, estral 
32. 28) Na maioria dos animais domésticos, o oócito é encontrado aderido na fase de metáfase II, exceto em uma das espécies isso não ocorre. Assinale a alternativa correta: *

Marcar apenas uma oval.
Bos taurus
Felis catus
Equus caballus
Canis lupus familiaris
Gallus gallus domesticus

33. 29) A cariogamia (cario = núcleo; gamia = junção) pertence a qual das fases da fecundação? *

Marcar apenas uma oval.
Primeira fase
Segunda fase
Terceira fase
Quarta fase
Quinta fase

34. 30) Na fecundação, a ativação ovocitária permite que a segunda divisão meiótica se complete. Neste processo, a célula-filha que possui baixa quantidade de citoplasma é denominada: *

Marcar apenas uma oval.

Oócito definitivo

Pro núcleo materno

Zigoto

Núcleo vesicular

Segundo corpúsculo polar 
35. 31) De acordo com Hyttel et al., (2010) a clivagem que ocorre seguida a primeira divisão mitótica, se completa no decorrer de quantas horas pós-ovulação nos animais domésticos? *

\section{Marcar apenas uma oval.}
12 horas
18 horas
20 horas
24 horas
32 horas

36. 32) 0 fenômeno da compactação dos blastômeros definido por Hyttel et al., (2010) que ocorre na fase de mórula, se dá após o estágio de quantas células? *

Marcar apenas uma oval.
Oito células
Doze células
Treze células
Vinte e duas células
Trinta células 
37. 33) 0 esquema abaixo representa a estrutura de um blastocisto. A partir dos indicativos em letras na figura é possível observar seus componentes estruturais, qual das sequências apresentada nas alternativas melhor representa a ordem alfabética? *

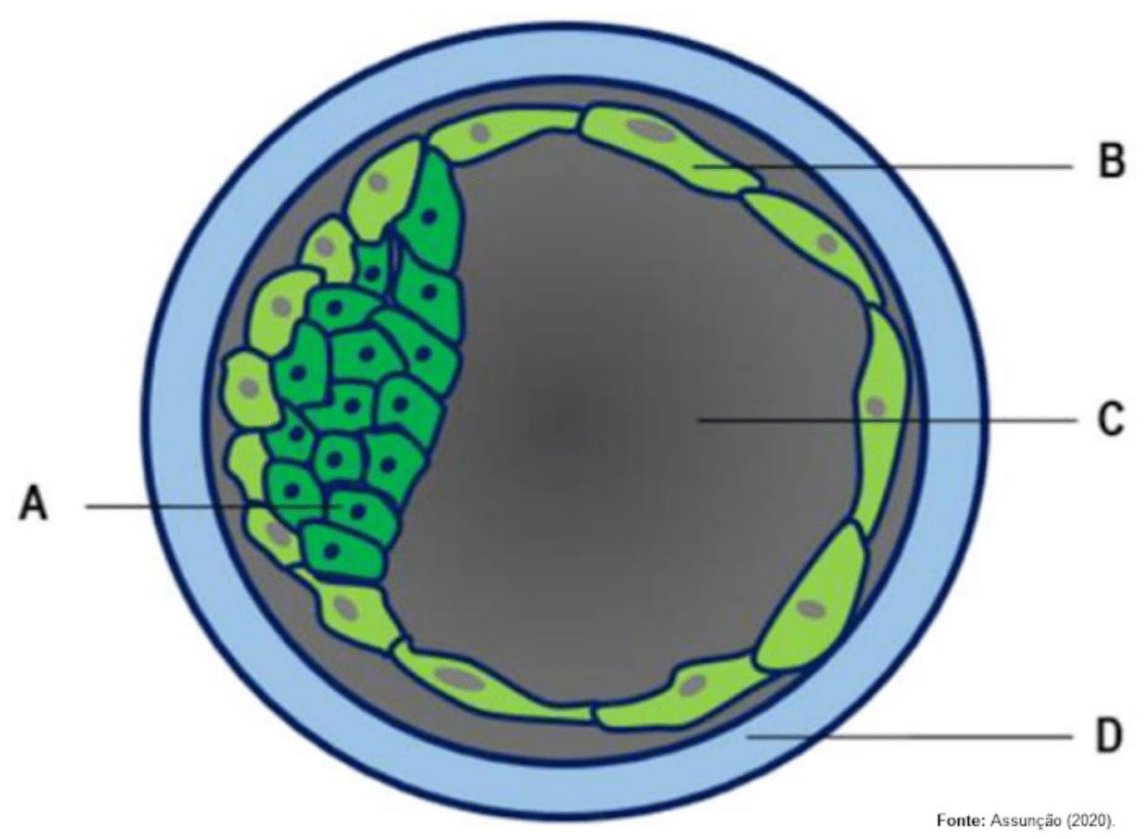

Marcar apenas uma oval.
Embrioblasto; Zona pelúcida; Trofoblasto; Blastocele
Blastocele; Zona pelúcida; Embrioblasto; Trofoblasto
Embrioblasto; Trofoblasto; Blastocele; Zona pelúcida
Zona pelúcida; Trofoblasto; Blastocele; Embrioblasto
Zona pelúcida; Embrioblasto; Trofoblasto; Blastocele 
38. 34) A blástula se apresenta em diferentes tipos, variando de acordo com o teor e com a distribuição do vitelo na célula ovo. Cite os 5 principais tipos. *

39. 35) A discoblástula apresenta-se de forma virtual e é representada pela cavidade subgerminal. A partir desta afirmação, este tipo blástula é típico de qual espécie animal? *

Este conteúdo não foi criado nem aprovado pelo Google.

Google Formulários 
APÊNDICE B - Livro-texto: Capítulos / E-book

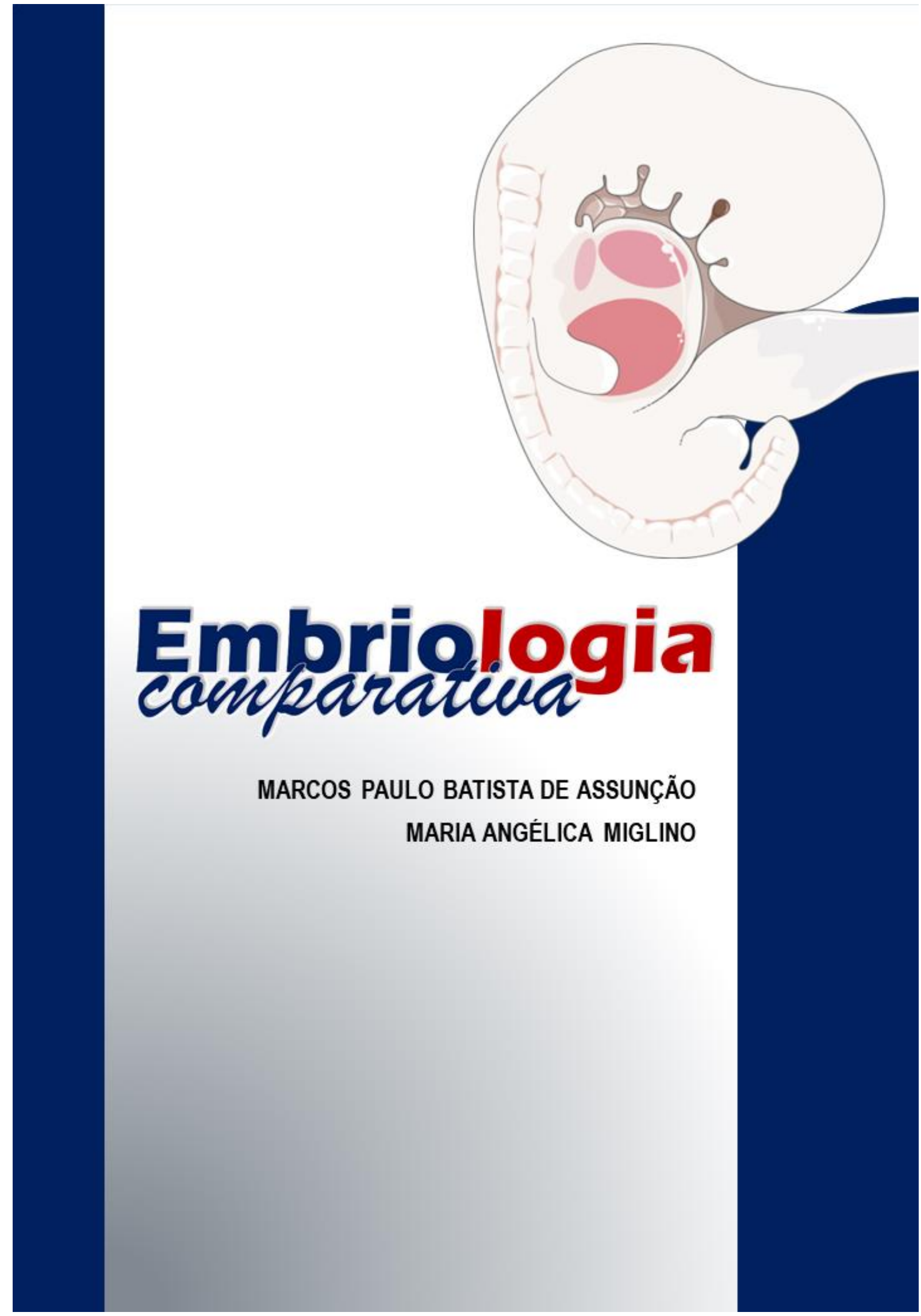



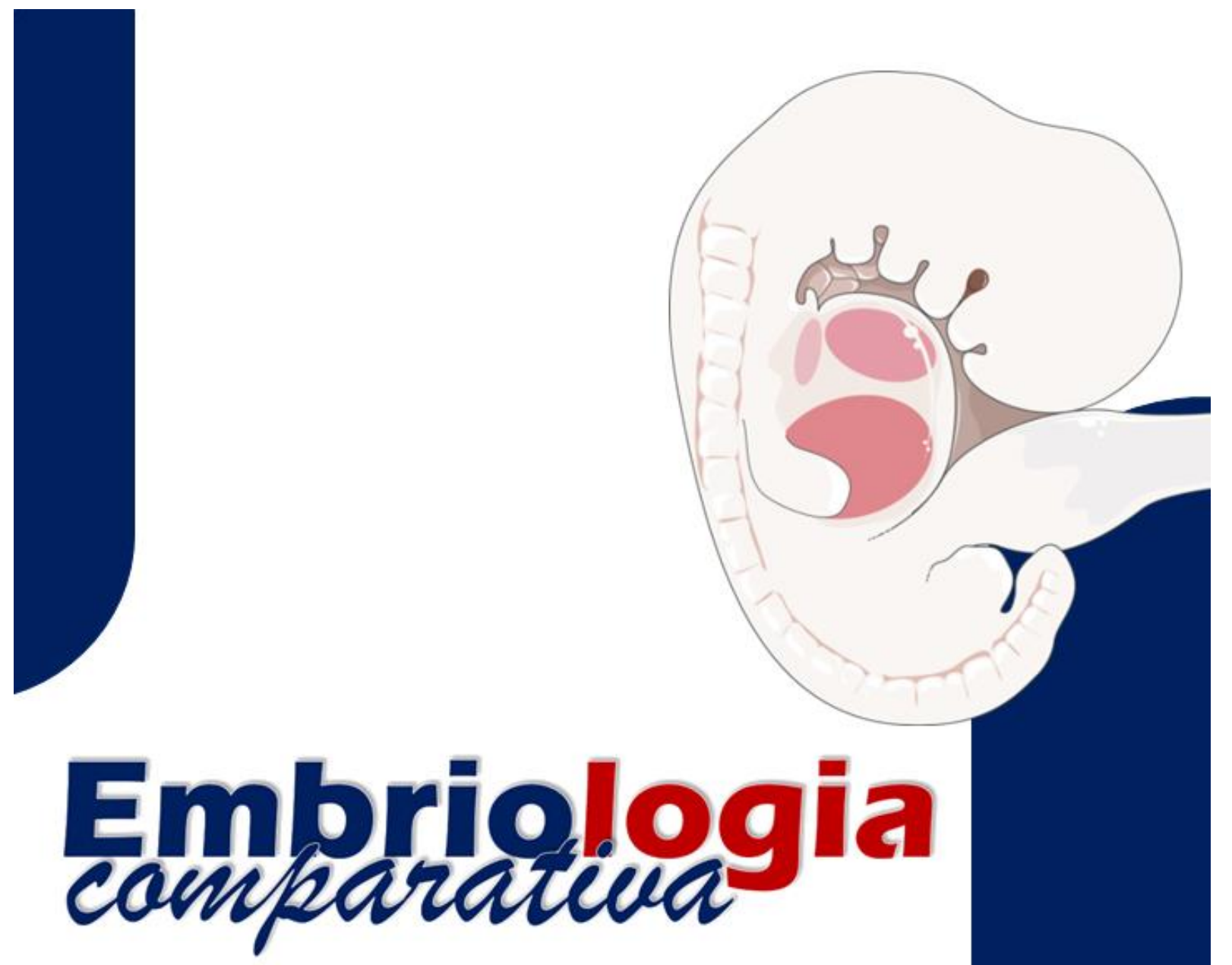

\section{MARCOS PAULO BATISTA DE ASSUNÇÃO Biólogo UFG Doutorando FMVZ-USP PG Anatomia dos Animais Domésticos e Silvestres}

MARIA ANGÉLICA MIGLINO Médica Veterinária Docente titular FMVZ-USP Orientadora do PG Anatomia dos Animais Domésticos e Silvestres
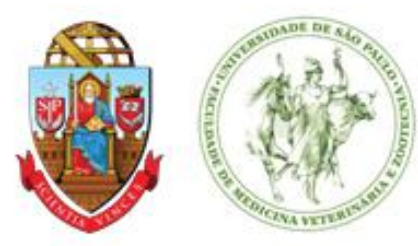

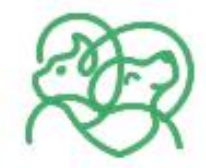

POSANATOVET.BR

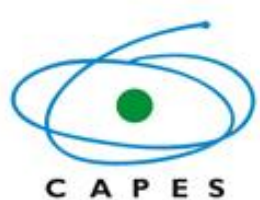

C A P E S

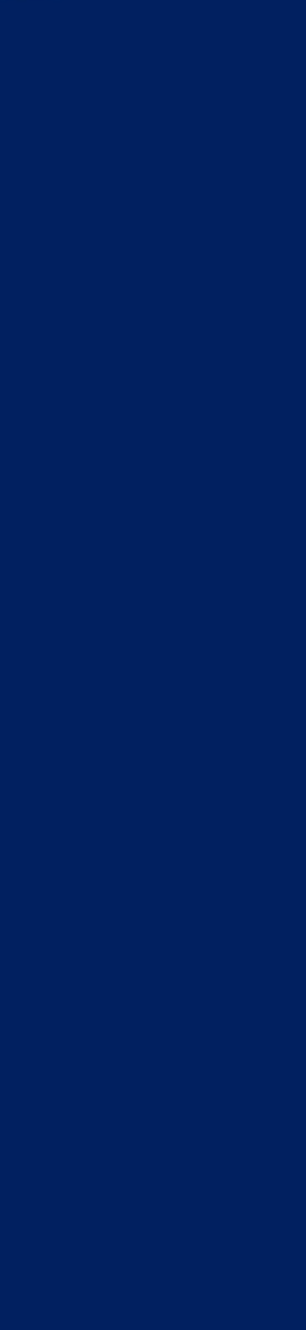




\section{Apresentação}

A educação nos dias atuais busca conteúdos selecionados e apropriados, bem como profissionais adeptos ao processo de ensino-aprendizagem, dentro e fora da sala de aula. Complementando as necessidades atuais, o ensino deve ser abordado de forma multidisciplinar, ligado às competências estratégicas de maneira contextualizada. Faz-se necessária uma organização dos conhecimentos, visando o desenvolvimento de métodos que sustentem o aprendizado e a compreensão das diferentes abordagens e de conteúdos essenciais aos desafios encontrados no dia-adia.

Os capitulos apresentados neste módulo, abordam o desenvolvimento embrionário de diferentes espécies de animais domésticos, a saber: caninos, felinos, equinos, bovinos, suinos e aves, possibilitando ao aluno aprender noções básicas e cientificas que contemplem desde a estrutura das células germinativas primordiais (CGPs), os conceitos gerais dos processos envolvidos no decorrer da fecundação (ou fertilização), a clivagem, a gastrulação, a neurulação e a organogênese, com foco no desenvolvimento do sistema cardiovascular.

A Embriologia Comparativa possibilita também o entendimento da evolução das diferentes espécies que constituem o Reino Animal, mediante obtenção de conhecimentos que poderão servir como conteúdo de livros-texto dedicados ao ensino da Medicina Veterinária, das Ciências Biológicas e de áreas afins. Tais conhecimentos envolvem a dinâmica das mudanças que ocorrem ao longo do desenvolvimento de espécies

Pelos motivos expostos, o presente texto foi redigido valendo-se de uma linguagem simples, clara e objetiva, visando facilitar a assimilação dos conteúdos. As atividades avaliativas ao final de cada capitulo, apresentam-se como parte da fixação do conteúdo, oportunizando os alunos realiza-las de maneira à aprender, mesmo durante a avaliação.

É importante ressaltar que todo o material aqui estruturado visa proporcionar clareza e compreensão dos conteúdos apresentados em cada capitulo, contribuindo para seu aprendizado. Um glossário se faz necessário, para facilitar a explicação dos eventos envolvidos em cada fase do desenvolvimento do concepto. 


\section{Objetivos Gerais}

- Selecionar conteúdo acerca dos conhecimentos que rege o estudo da Embriologia comparativa;

- Disponibilizar em uma plataforma digital de ensino conhecimentos inerentes à formação dos gametas tanto macho quanto da fêmea, a fecundação e os ciclos reprodutivos envolvidos no desenvolvimento;

- Envolver ainda na plataforma conhecimentos referentes às transformações de uma estrutura unicelular (Zigoto) para multicelular (Blástula), assim como a formação dos três folhetos embrionários fundamentais, bem como o desenvolvimento do tubo neural (Nêurula). Esboçar o percurso dos folhetos germinativos após a ocorrência da diferenciação, apresentando as particularidades do desenvolvimento dos animais domésticos. 


\section{Sumário}

Glossário. 1

Capitulo 1 - Introdução a Embriologia Comparativa............................. 6

Capitulo 2-Gametogênese............................................................... 17

Capitulo 3 - Fecundação......................................................................... 32

Capitulo 4- Mórula.................................................................................. 41

Capitulo 5- Blastulação..................................................................... 51

Capitulo 6 - Gastrulação.................................................................. 59

Capitulo 7- Neurulação......................................................................... 66

Capitulo 8 - Organogênese................................................................... 72

Capitulo 9- Desenvolvimento do Sistema Cardiovascular............... 78

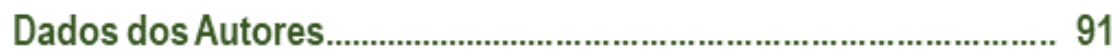

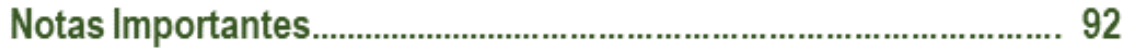




\section{GLOSSÁRIO}

ACTINA | Proteina ligada ao movimento celular, nos músculos apresentam-se em grande quantidade, sendo responsável pela contração muscular associada a troponina e à tropomiosina, na fisiologia é estudada mais detalhadamente.

ANEXO EMBRIONÁRIO | Nome genérico de uma estrutura formada no desenvolvimento do embrião e a ele ligada; os anexos embrionários estão presentes nos répteis não-aves, répteis aves e mamiferos.

ARQUÊNTERO | Gastrocela (ou intestino primitivo); cavidade presente na gástrula, que corresponde à futura cavidade digestiva.

ALANTOIDE | Anexo embrionário membranoso ligado ao intestino primitivo; sua função é armazenar as excreções do embrião até o nascimento.

ASSEXUADA | Individuo sem sexo; refere-se à reprodução que não envolve fusão dos gametas.

BLASTOCISTO | Estrutura que refere-se à um dos estágios iniciais dos embriões de mamiferos, ou ainda, corresponde à fase de blástula no mamifero, e contém células capazes de originar diferentes tipos celulares.

BLASTÓPORO | Abertura que comunica o intestino primitivo (ou arquêntero) do embrião com o meio externo.

BLÁSTULA | Fase do desenvolvimento em que o embrião tem um aglomerado de células oca e que sucede o estágio de mórula.

CÉLULA TOTIPOTENTE | Célula indiferenciada que poderá originar células dos mais diferentes tecidos.

CELOMA | É uma cavidade inteiramente limitada pela mesoderme e que corresponde a cavidade interna do corpo de certos animais.

COLÁGENO | Proteina principal da pele, do tecido conjuntivo propriamente dito, das cartilagens, dos ossos, dostendões e dos ligamentos.

CORDADOS | Animal triblástico, œlomado, com notocorda, aquático ou terrestre, pertencente ao filo Chordata.

CROMOSSOMOS AUTOSSÔMICOS | Refere-se a cada um dos cromossomos presentes tanto em machos quanto em fêmeas; na espécie humana, por exemplo, homens e mulheres têm 22 pares de autossomos em suas células. 
DESMOSSOMOS | Reforços localizados entre as células com o objetivo de aumentar a adesão entre células vizinhas.

DEUTEROSTOMIA | Designação do animal triblástico em que a boca se forma posteriormente ao ânus.

DIAPEDESE | Ato de atravessar as paredes dos capilares sanguineas, executado por células como leucócitos e macrófagos.

EMBRIOGÊNESE | Processo de formação do embrião. Em galinha por exemplo, o estágio de embrião vai de, aproximadamente, 14 dias. A partir do décimo quarto dia, é chamado feto.

ENDÓCRINA | Refere-se as glândulas de secreção interna, estas produzem e lançam hormônios na corrente sanguinea.

ESPERMÁTIDE | Célula haploide formada durante a espermatogênese, ao lago do desenvolvimento a referida célula se diferenciará no espermatozoide.

ESPERMATOGÔNIA - Célula resultante da multiplicação das células germinativas primordiais (CGPs) do macho. Após o crescimento, uma espermatogônia transformase em um espermatócito.

EXOCITOSE | Saida de macromoléculas por meio da membrana plasmática (MP). As vesiculas de exocitose colocam-se próximos à membrana, pelo lado interno, e se abrem, eliminando seu conteúdo para o exterior.

FECUNDAÇÃo (OU FERTILIZAÇÃO) | Processo de união e fusão de um par de gametas originando a célula ovo (ou zigoto).

FIBROBLASTO | Célula do tecido conjuntivo responsável pela produção de fibras.

GASTRULAÇÃO | Estágio do desenvolvimento embrionário onde se forma o intestino primitivo (arquêntero); é a fase que sucede à blástula.

GENOMA | Lote completo de genes, típico da espécie; uma célula haploide tem um genoma; uma diploide possui dois.

GÔNADAS | Órgão sexual onde ocorre a produção de gametas.

HAPLOIDES | Célula que apresenta apenas um cromossomo de cada tipo, isto é, não apresenta cromossomos homólogos; o número de tipos cromossômicos é representado por $\mathrm{n}$.

HEMATOPOIÉTICO | Órgão ou estrutura formadora de sangue. 
MEROBLÁSTICA | Segmentação parcial; tipo de segmentação na qual devido a densidade do vitelo, o ovo é parcialmente segmentado.

MESODERMA | Tecido situado entre o ectoderma e o endoderma, presente somente em embriões triblásticos; um dos três folhetos germinativos desses animais.

MESENTODERMA | Camada celular da gástrula da qual se origina o mesoderma e o endoderma em espécies como o anfioxo.

MICROVILOSIDADES | Projeções da membrana celular destinadas a aumentar a absorção das mesmas, como acontece com as células intestinais.

MÓRULA | Aglomerado de células sem nenhuma cavidade, a mórula é resultante das primeiras divisões do zigoto; estágio inicial da embriogênese.

NEURULAÇÃo | Estágio do desenvolvimento embrionário caracterizado pela formação do tubo neural (ou nervoso).

NIDAÇÃo | Processo de implantação da célula-ovo no útero.

NOTOCORDA | Bastão de células semirrigidas cartilaginosas, localizadas sob o tubo nervoso; constitui o primeiro eixo de sustentação do embrião dos cordados; nos vertebrados é substituido pela coluna vertebral.

ORGANOGÊNESE | Formação e desenvolvimento dos órgãos, que acontece durante o desenvolvimento embrionário, sucedendo a histogênese.

OVÍPAROS | Refere-se ao animal que põe ovos; os embriões se desenvolvem fora do organismo materno; o termo oviparo é mais empregado para os vertebrados; são considerados animais oviparos certos peixes, anfibios, œrtos répteis não-aves, os répteis aves e alguns mamiferos.

OVOGÊNESE | Processo pelo qual as células germinativas das fêmeas diferenciamse em gametas (ou óvulos).

PARTENOGÊNESE | Desenvolvimento de um óvulo sem que haja fecundação.

PROGESTERONA | Hormônio produzido pelo corpo amarelo do ovário e também pela placenta; seu efeito é preparar o organismo da fêmea para o desenvolvimento embrionário; entre outros efeitos, causa o grande desenvolvimento do endométrio.

QUERATINA | Proteina fibrosa presente nos animais vertebrados, é um material que constitui as unhas, garras, pêlos e que impregnam na superficie da epiderme

SEGMENTAÇÃO | Divisão de células tanto vegetais quanto animais 
TÚBULOS SEMINÍFEROS | Túbulos presentes no testiculo dos mamiferos que encontra-se na bolsa escrotal e em cujas paredes diferenciam-se os espermatozoides. TROFOBLÁSTICA | Camada externa e delgada do embrião da qual se origina parte da placenta.

VITELO | Substância de reserva nutritiva presentes no citoplasma dos ovos; sua função é alimentar o embrião durante as primeiras fases do seu desenvolvimento; no caso em especifico da galinha por exemplo, as reservas nutritivas, nutri o individuo até a eclosão do ovo.

VERTEBRADOS | Subfilo que reúne os animais que apresentam vértebras pertencentes ao filo Chordata

ZONAS DE OCLUSÃO | Pontos de contato entre membranas de células adjacentes com a finalidade de aumentar a união.

CORONA RADIATA | Membrana que envolve o ovócito (ou oócito), formadas por células foliculares derivadas do ovário.

ZONA PELÚCIDA (OU ZP) | Camada de glicoproteinas que envolve o óvulo e confere aos gametas da fêmea uma alta especificidade.

HOLOBLÁSTICA | Segmentação total; tipo de segmentação em que a célula ovo é dividida completamente em blastômero.

SINCícıO | Estrutura multinucleada resultante da fusão de várias células; a fibra muscular estriada, por exemplo, é um sincicio 

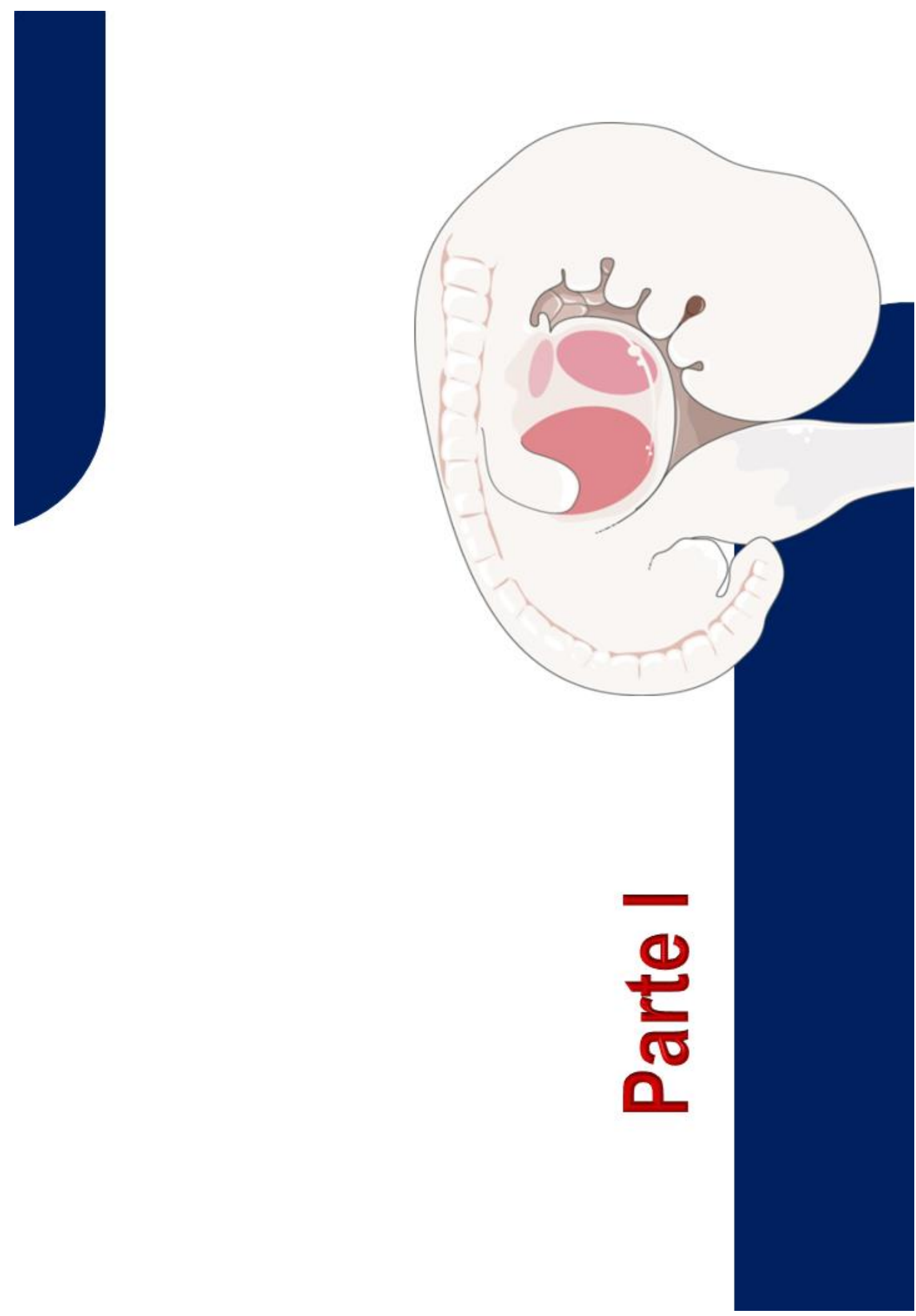


\section{Capítulo}

\section{INTRODUÇÃO A EMBRIOLOGIA COMPARATIVA}

\section{Introdução e Conceitos Gerais}

O estudo do desenvolvimento animal integra a chamada Anatomia do Desenvolvimento, parte da ciência experimental ou descritiva, a qual desde a antiguidade estuda as diferentes fases transcorridas entre a fecundação e o nascimento do embrião (Figura 1). A fase inicial do desenvolvimento é denominada fase embrionária, sendo o estudo da mesmo conhecido como embriologia.

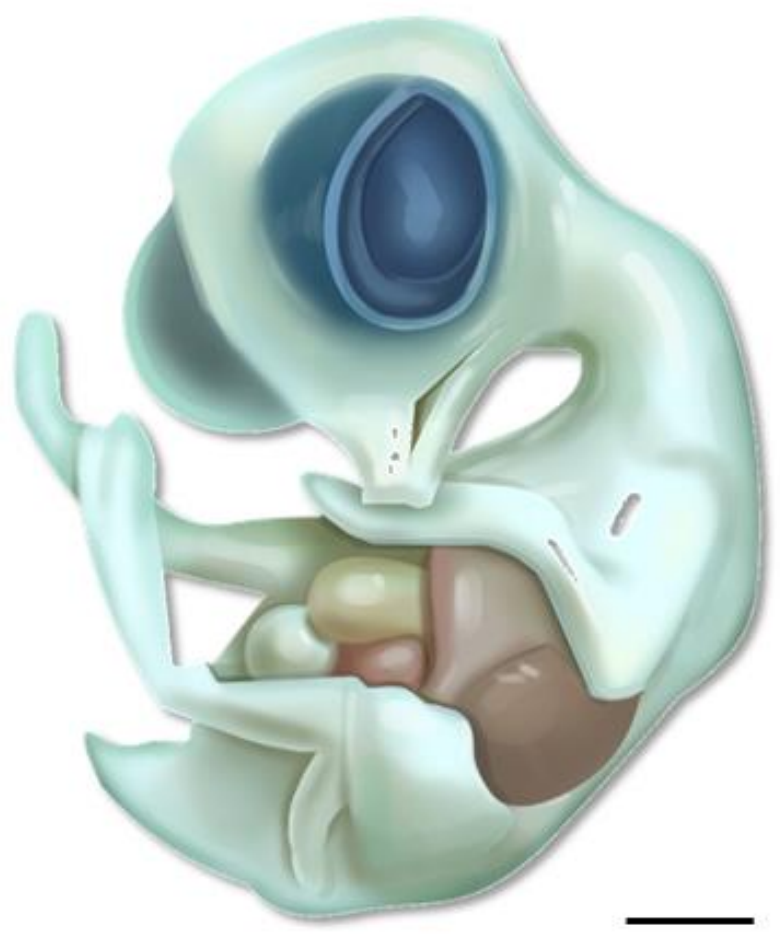

Embrião é o estágio jovem do animal enquanto consido no ovo ou no corpo uterino. Ele é o intermediário entre 0 genóspo e o fenóspo, ou seja, entre os genes herdados e o ser adulto.

Desenvolvimento é todo 0 processo continuo e organizado que se inicia no momento em que um oóctio é fecundado por um espermatozoide e termina ao nascimento. Para que a célula germinafiva, o oócito, seja fecundado pelo espermatozoide, é necessário que estas duas

Figura 1. Exemplo didáico de um embriäo de aves (Gallus gallus domesticus) com 9 dias do desenvolvimento embrionário. Barra referente a $1 \mathrm{~cm}$. Fonte: Assunção (2020). células gaméicas estejam formadas, evento fundamental parao inicio da gametogênese. 
Didaticamente, no universo das Ciências Biológicas, a Embriologia prima por ocupar posição de destaque entre as demais subáreas e especialidades, devido a condição basal sobre a qual se fundamenta a quase totalidade daquelas que por sua vez adquire extrema importância para uma adequada compreensão da forma e das suas relações com as funções. Tratando-se das Ciências Médicas, no caso especifico da Medicina Veterinária, o embasamento tanto embriológico quanto anatômico sustentam conhecimentos acerca das mal formações congênitas, da prática médica e cirúrgica, da clínica e de outras especialidades veterinárias.

Embriologia, etimologicamente significa "estudo dos embriões", e embriões são conceptos onde cujos estágios do desenvolvimento ocorrem antes da organogênese, ou seja, antes da formação dos órgãos, e após a fecundação. 0 embrião passa por transformações em um periodo relativamente pequeno de tempo, $\mathrm{e}$ em determinado momento começa a sofrer o processo de diferenciação dos órgãos, passando a adquirir caracteristicas próprias, as quais definem a espécie, transformando-se em feto.

Podemos afirmar, ainda, que a fecundação nos animais ocorre mediante o contato entre o espermatozoide e o óvulo. Em geral, os espermatozoides são células flageladas, mas, existem exceções. O óvulo são células globóides demonstrando serem maiores que os espermatozoides. Com a junção do espermatozoide e o óvulo, inicia-se uma etapa do desenvolvimento denominada de fecundação. Após a fecundação ocorre o primeiro estágio do embrião, denominado zigoto. O zigoto é constituido por um núcleo, o qual está presente no polo do concepto. Mediante reservas nutritivas, o futuro embrião é nutrido no seu primeiro momento do desenvolvimento.

Algumas espécies animais já possuem reserva nutritiva suficiente para fazer com que o embrião seja alimentado durante todo o tempo do seu desenvolvimento até seu nascimento. Entretanto, em outras espécies, as reservas nutritivas não são suficientes para nutrir o embrião e o feto, até que o concepto se defina como um ser completo. A reserva nutritiva (lipideos e proteinas) localizada no polo vegetativo pode ser chamada de vitelo (ou gema), e pode ser observada durante todo o desenvolvimento embrionário de répteis não-aves, como por exemplo no desenvolvimento de galinha (Gallus gallus domesticus). 
A base de classificação do Reino Animal sustenta-se no seu desenvolvimento, sendo possivel definir a partir do mesmo a blastia, a estomia e o celoma das mais diferentes espécies animais. A blastia é definida por caracteristicas referentes aos folhetos embrionários, tais como os tecidos primordiais para o desenvolvimento do animal; a estomia é definida pela formação bucal; já o celoma por meio da formação da cavidade visceral

Segundo Hyttel (2010) o embrião formado a partir do zigoto passa por seus três principais momentos de desenvolvimento. Primeiramente o zigoto se multiplica de maneira a realizar sucessivas mitoses de forma binária, ou seja, segmentam-se, fenômeno conhecido como divisões celulares. Em um segundo momento, o mesmo se organiza para dar origem à formação da cavidade digestória e dos folhetos embrionários (gastrulação). Por fim, a formação dos órgãos (organogênese) ocorre, ocasião na qual é finalizado o processo de desenvolvimento embrionário

À semelhança da Anatomia, à Embriologia é conhecida tanto como ciência, quanto arte. Ciência, porque seus conhecimentos são investigados e expostos logicamente como realidades sob o dominio de um principio como por exemplo, a energia estática da substância organizada; arte pois, sugere a reformulação de ideias relativas ao procedimento na aquisição dos seus conhecimentos, podendo ser aplicados onde convier.

O estudo acerca da Embriologia Comparada tem-se alicerçado no aprimoramento de técnicas mais avançadas de investigação, pois o advento da microscopia permitiu a expansão de novas descobertas e, paralelamente, sugeriu a necessária divisão das diferentes fases do desenvolvimento.

\section{Divisões da Embriologia}

A embriologia pode ser abordada de acordo com as seguintes divisões:

- Embriologia geral: correlaciona o desenvolvimento dos embriões desde a fase de fecundação até a formação do tubo neural (fase de nêurula);

- Embriologia especial (organogênese): fase do desenvolvimento dos órgãos e sistemas que constituem o individuo; 
- Embriologia morfológica: estuda as formas das estruturas anatômicas, tecidos e órgãos, desde a forma dos gametas até o desenvolvimento completo do ser vivo;

- Embriologia descritiva: descreve os fatos marcantes de forma separada, dando mais ênfase as estruturas que surgem no decorrer do periodo embrionário;

- Embriologia comparativa: estuda concomitantemente a formação e o desenvolvimento de embriões dos diferentes grupos do reino animal que fazem parte da escala zoológica e estabelece de forma comparativa os aspectos macro e microscópicos das mesmas estruturas das mais diferentes espécies;

- Embriologia patológica: estuda as alterações do desenvolvimento normal e anormal, ou seja, as más-formações congênitas;

- Embriologia química: tem por objetivo investigar os processos bioquímicos que ocorrem no decorrer do desenvolvimento embrionário;

- Embriologia fisiológica: conhece e descreve as funções de estruturas morfológicas e órgãos das diferentes fases/estágios do desenvolvimento;

- Embriologia experimental: estuda a relação do desenvolvimento embrionário com as questões ambientais e a interdependência do todo e das estruturas de formação entre si.

Em passos largos, a Embriologia em geral estuda a anatomia do concepto, acompanhando todas as fases do seu desenvolvimento. A antogênese é a história do desenvolvimento do individuo, ao passo que a filogênese acompanha o desenvolvimento da espécie.

Em abordagem descritiva, a Embriologia, tanto na fase de fecundação e formação do embrião, quanto na observação da origem e desenvolvimento dos tecidos primordiais para formação do individuo, desempenha papel cada vez mais relevante para a formação de novos pensadores e profissionais que por ela se interessam, mesmo porque tais conhecimentos são imprescindiveis à compreensão do desenvolvimento como parte de um todo. As fases compreendem: Gametogênese, Fecundação, Mórula, Blástula, Gástrula, Nêurula e Organogênese (Figura 2). Assim, o 
periodo e a fase embrionária propriamente ditos, variam de acordo com a espécie segundo Evans \& Sack (1973).

\section{EMBRIOLOGIA}

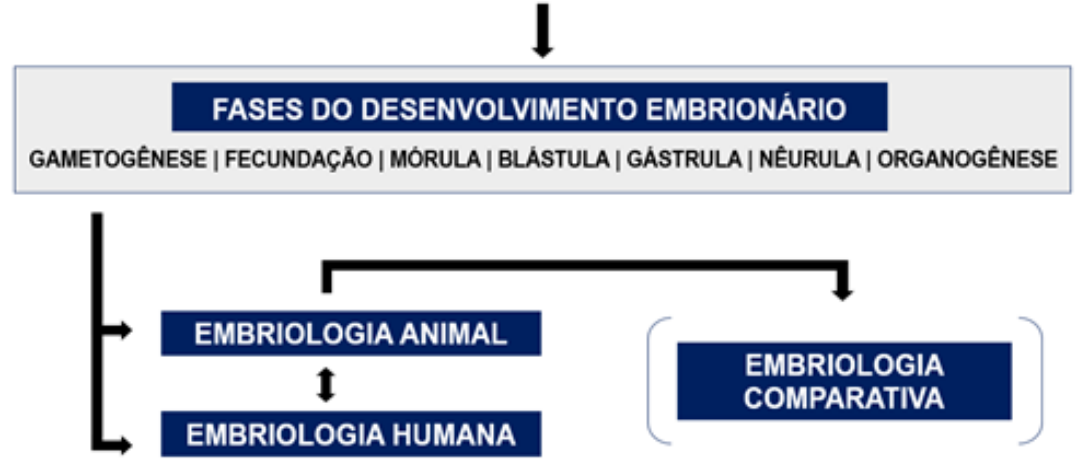

Figura 2. Fluxograma acerca do estudo da embriologia. Nota-se que para o desenvolvimento de um ser completo, vários estágios ocorrem ao longo do período embrionário. Existem subáreas para o estudo da embriologia, esta quando estudada de forma comparada entre grupos de animais dá-se o nome de embriologia comparativa. Fonte: Assunção (2020).

Mais detalhadamente, a Embriologia comparativa é um ramo da Embriologia, conforme o próprio nome sugere, que estabelece as possiveis correlações de forma comparativa entre os aspectos macro e microscópicos de diferentes espécies animais. Numa abordagem ampla na escala zoológica naquilo que se refere ao Reino Animal, vem atender o interesse dos profissionais das Ciências Biológicas e áreas afins, porém, quando visa especificamente os animais domésticos, contempla também os interesses dos médicos veterinários.

\section{Fundamentos Históricos da Embriologia Comparativa}

Ao longo dos anos, o deslumbramento entre embriologistas pela maneira a qual a "vida" se desenvolve, deu origem a diversos questionamentos sobre a complexidade deste processo e suas inter-relações. Gilbert et al., (2006) relatam que documentos egipcios e sânscritos já continham descrições de embriões e que grande parte dos mais diversos e antigos filósofos se interessavam pela embriologia. Assim, as buscas pela 
No livro sagrado dos mulçumanos (Alcorão), há relatos que 0 desenvolvimento do individuo advém da mistura de secreçōes do homem e da mulher. $O$ livro ainda relata a importância do espermatozoide para a criação do individuo, para eles, o esperma é a semente que se fixa no corpo da mulher após seis dias do inicio do seu desenvolvimento (a implantação do blastocisto realmente se dá nessa época). Fonte: www.sbmrj. org.br/Alcorao-ciencia2.hm. compreensão destes mecanismos são pertinentes e discutidas em meio a sociedade contemporânea. Tratando-se dos animais domésticos e silvestres, respectivamente, estes são de extrema importância devido à sua grande variedade e abrangência (MENEZES, 2001; CONCEIÇÃO, 2008).

De acordo com Demócrito (455-370 a.C.) o sexo de um individuo era determinado pela origem do espermatozoide, ou seja, os machos seriam provenientes do testiculo direito e as fêmeas do testiculo esquerdo. No entanto, esta hipótese foi modificada por Pitágoras, Hipócrates e Galeno, uma vez que para a ciência, a definição do sexo sempre foi privilégio do homem; os filósofos em sua maioria colocavam as fêmeas entre os homens e os animais, portanto, os machos eram originados de um espermatozoide de alto potencial que provinha do testiculo direito.

O primeiro embriologista conhecido da época foi o filósofo grego Aristóteles (384-322 a.C.) por realizar os primeiros estudos embriológicos de maneira sistemática e organizada. Aristóteles descreveu o desenvolvimento embrionário de animais e dentre eles o desenvolvimento embrionário de galinha, onde fez a mais importante descoberta - o embrião desenvolve seus sistemas de órgãos gradualmente. Na obra $A$ geração dos Animais (350 a.C.) identificando os diferentes tipos pelos quais os animais nasciam podendo ser pela oviparidade, viviparidade ou ovoviviparidade, descreveu ainda os dois grandes padrões de clivagem embrionária, como sendo: holoblástica ou meroblástica e as funções da placenta, e do cordão umbilical que em bovinos por exemplo, possuiam funções fundamentais para nutrição fetal.

Os estudos acerca da embriologia se desenvolveram muito lentamente junto a anatomia descritiva, onde a primeira descrição anatômica de útero prenhe de porcas foi feita por Kopho no inicio do século XIII em um de seus trabalhos Anatomio Porci usando porcos como modelos experimentais. A partir disso, œm o Renascimento, estudos anatômicos descritivos ficaram cada vez mais reconhecidos, o que coincidiu com a impressão de livros por Johann Gutenberg.

Deste modo, a principal publicação como marco para embriologia comparada foi em 1600 pelo renomado anatomista italiano da época Hieronymus Fabricius de Acquapendente (1533-1619) que descreveu e ilustrou a anatomia macroscópica de embriões e suas membranas na obra De Formato Foetu. Mas, Acquapendente não foi o primeiro a fazer isso; o anatomista italiano Bartolomeu Eustáquio (1514-1574) havia 
previamente publicado ilustrações de embriões de cães e ovelhas no ano de 1552. Portanto, é possivel reconhecer o nome de Fabricius em Bursa Fabricii na porção imunológica do intestino de aves, e de Eustáquio na trompa de Eustáquio, hoje como epônimo

Os achados de Eustáquio, Fabricius e outros cientistas forneceram ideias primordiais para dúvidas pertinentes às questões de desenvolvimentos dos órgãos em sua forma em fase inicial até a maturação, mas deixa um enigma básico sem resposta: "como e onde se originam os embriões mamiferos?". Foi a partir dai que o médico italiano Marcelo Malpighi (1628-1694), valendo-se do desenvolvimento do microscópio Zacarias Janssen (1590) publicou os primeiros relatos do desenvolvimento embrionário de galinhas criando uma revolução na embriologia descritiva. Com isso, Janssen identificou ainda o sulco neural, somitos e a circulação de sangue nas artérias e veias do vitelo (GILBERT, 2006).

Em meados do século XIX após a revolução dos aspectos embriológicos muitos nomes da ciência se destacaram, entre eles Karl Ernst von Baer, Richard Owen e Ernst Haeckel. Von Baer (1828) e Haeckel (1866) realizando grandes estudos comparativos com séries ontogenéticas de embriões vertebrados, puderam observar importantes aspectos no desenvolvimento, correlacionando-os com a origem e a existência de planos sistêmicos comuns aos diversos grupos de animais (RICHARDSON \& KEUCK, 2002)

Segundo Hall (1992), as ideias elaboradas por Von Baer; Richard Owen (1840) versavam sobre questões de analogia e homologia do desenvolvimento embrionário. 0 autor ainda reporta que Richard Owen utilizou os conceitos abordados por Karl Ernst von Baer (1792-1876) para apresentar a existência de um plano de desenvolvimento em comum às diferentes espécies. Acreditava-se que a partir deste plano, surgia um tipo morfológico comum, do qual derivavam-se modificações. Foi von Baer em 1827 que ao abrir o "Ovo de Graaf" encontrou um ponto amarelo e o examinou através de um microscópio óptico. Assim, o "ovo" de mamiferos foi identificado.

Ao identificar o óvulo de mamiferos, Von Baer medrou às investigações tomando como referência os achados de Christian Pander (1794-1865) em embriões de galinha, e descreveu a notocorda pela primeira vez. Em meados do século XIX, o biólogo alemão Von Bischoff (1807-1882) em minuciosas observações por meio de
No século XX, a teoria préformista apresentou-se com duas correntes, embora admitissem igualmente que os gametas eram a miniatura do adulto: a) Homunculistas: miniatura do individuo no espermatozoide, o útero seria 0 "campo" e o ovo o alimento; b) Ovistas: a miniatura estava no ovo, o liquido seminal estimulava 0 desenvolvimento. Esta teoria baseava-se nas observações de ovo de galinha com indicios de formação embrionária. 
colorações especificas e técnicas microscópicas, detalhou os estágios de clivagem em coelhos. No homem e em espécies domésticas este processo foi descrito pelo anatomista e fisiologista suiço von Kölliker (1817-1905), o qual em 1861 publicou o livro-texto sobre a embriologia humana e animal.

Entre o final do século $\mathrm{XIX}$ e inicio do século $\mathrm{XX}$, os embriologistas americanos Beecher Wilson; Hunt Morgan e Heinrich Boveri (1856-1915) descobriram que a hereditariedade residia no citoplasma ou até mesmo no núcleo celular do ovo fertilizado, despertando questões genéticas a partir da embriologia. A ideia era baseada nos alelos cromossômicos os quais foram estudados por Beecher Wilson e Maria Stevens (1861-1912) dando continuidade aos trabalhos de Boveri, de forma a caracterizar questões fenotipicas relacionando-as às propriedades do núcleo. Até então, ambas as especialidades não eram tratadas como distintas. Foi Morgan (1920), que definiu que a Genética se divergia da embriologia, uma vez que a Genética segundo ele estudava a transmissão das caracteristicas hereditárias, enquanto que a Embriologia a expressão destas (HYTTEL, SINOWATZ \& VEJLSTED, 2010).

A embriologia como ciência apresenta-se em desenvolvimento exponencial. Na metade do século XIX a embriologia foi incorporada ao ensino da Anatomia descritiva e passou a integrar os curriculos dos cursos em Medicina, Medicina Veterinária e Ciências Biológicas fazendo assim seu caminho. Em 1924 foi publicado por Zeitzschmann o livro-texto de Embriologia, entre outros (embora poucos). No entanto, a partir dai destacaram-se as obras Embryology of the Pig de Bradley M. Patten, e a Biologia do Desenvolvimento de Scott F. Gilbert, sendo que este último contemplava a Embriologia Comparativa. Baseada na linguagem grega e latina a "Nomenclatura Embriológica" surgiu a fim de facilitar os mais diferentes termos utilizados nesta ciência, e mesmo passando por modificações ao longo dos anos, utiliza-se a mesma como base até os dias atuais.

\section{Métodos de Estudo da Embriologia Comparativa}

O estudo morfológico a olho nu apresentou-se como o primeiro método de estudo do desenvolvimento embrionário. Com a inserção do microscópio foi possivel obter observações mais detalhadas e minuciosas dos seres em desenvolvimento. 
Em meados do século XX, segundo Vanderley \& Santana (2015) desenvolveuse a técnica histológica dos cortes seriados. Com esta técnica uma série continua de cortes de um mesmo embrião era possivel de ser obtida, facilitando a verificação e a descrição de toda estrutura a nivel celular. Foi a partir desta adequação que a confeç̧ão de modelos para serem visualizados macroscopicamente em 3D ocorreu. Mediante outras técnicas, como por exemplo, a introdução de métodos fisiológicos, bioquimicos e biofisicos, foi possivel elucidar os fenômenos fundamentais que regem a evolução dos seres vivos.

Assim, a Embriologia que era quase um ramo da morfologia, œm o surgimento de novas tecnologias tornou-se uma especialidade ativa e promissora das ciências que estudam o desenvolvimento dos mais diferentes seres vivos sob diversos aspectos.

\section{Atividades}

a) Cite as três principais classificações da Embriologia.

b) Reservas nutritivas são suficientes para nutrir o embrião e o feto até que um novo concepto se defina como um ser completo? Justifique sua resposta.

c) Diferencie a Embriologia Descrita da Embriologia Morfológica.

d) 0 zigoto é o primeiro estágio embrionário constituido por um núcleo. A partir desta afirmação, em qual dos polos o núcleo é localizado?

e) 0 embasamento tanto embriológico quanto anatômico possibilitará conhecimentos para diversas intervenções na área das Ciências Biológicas e Medicina Veterinária, cite 3 delas. 


\section{Referências}

CONCEIÇÃO, R. A.; AMBRÓSIO, C. E.; MARTINS, D. S.; CARVALHO, A. F.; FRANCIOLLI, A. L. R; MACHADO, M. R. F.; OLIVEIRA, M. F. \& MIGLINO, M. A Aspectos morfológicos do saco vitelino em roedores da subordem Hystricomorpha: paca (Agouti paca) e cutia (Dasyprocta aguti). Pesq. Vet. Bras. 28:253-259. 2008.

EVANS, H. E.; SACK, W. O. Prenatal development of domestic and laboratory mammals: growth curves, external features and selected references. Anatomy, Histology and Embryology, v. 2, p. 11-45, 1973

GARCIA, S. M. L.; FERNANDEZ, C. G. Ferramentas metodológicas para o estudo de problemas de biologia do desenvolvimento. In: Embriologia. 2. ed. Porto Alegre: Artmed, 2001. p. 21-32.

GILBERT, S. F. Developmental Biology. 8th ed. Sinauer Associates. 814p. 2006

HALL, B. K. Evolutionary Developmental Biology. Chapman e Hall Suffolk. 275p. 1992.

HYTTEL, P.; SINOWATZ, F. \& VEJSTED, M. Domestic Animal Embryology. 11th ed Saunders, Elsevier, p.359. 2010

MENEZES D. J. A.; CARVALHO, M. A. M.; CAVALCANTE FILHO, M. F. \& SOUZA, W. M. Configuração do sistema venoso portal na cutia (Dasypocta agouti, Rodentia). Braz. J. Vet. Res. Anim. Sci. 38:263-266. 2001.

RICHARDSON, M. K. \& KEUCK, G. Haeckel's ABC of evolution and development. Biological Reviews. 77:495-528. 2002.

VANDERLEY, C. S. B. S. \& SANTANA, I. C. H. Histologia e embriologia animal comparada. 2. ed. - Fortaleza: EdUECE, 2015. 

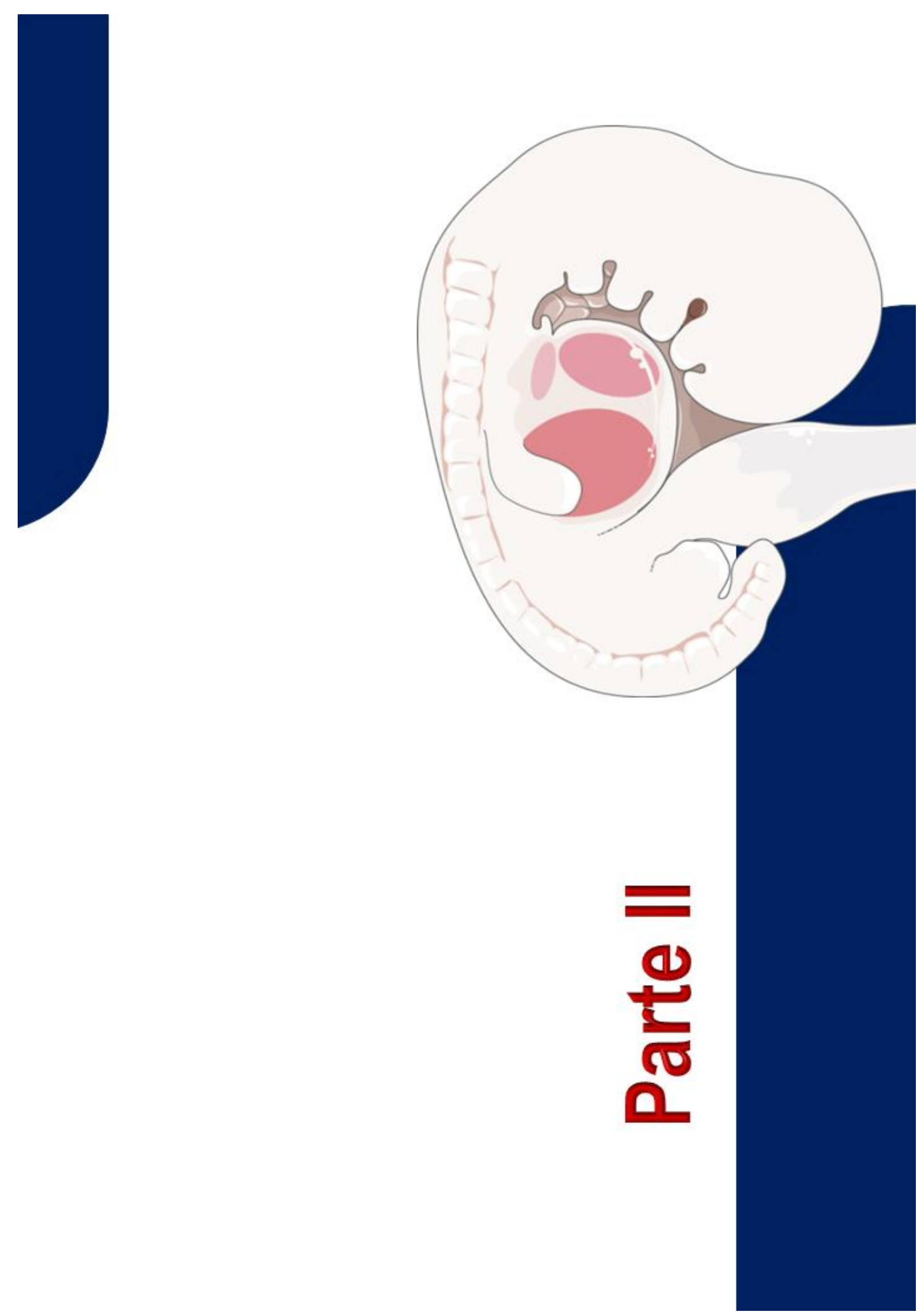


\section{Capítulo}

\section{GAMETOGÊNESE}

\section{Introdução e Conceitos Gerais}

A Gametogênese consiste em um conjunto de processos que envolve a formação e o desenvolvimento de células germinativas especializadas, ou seja, a formação de gametas os quais têm origem em organismos dotados de reprodução sexuada.

Nos animais, a gametogênese aparece nas gônadas, órgãos que também produzem os hormônios sexuais e que também determinam as caracteristicas sexuais que diferenciam individuos machos das fêmeas. 0 estudo da gametogênese em geral, baseia-se nos principios fundamentais que regem seu processo e, aqui, de forma comparativa, estabelecendo as principais diferenças entre espécies domésticas.

$\mathrm{O}$ evento fundamental da gametogênese é a meiose. Esta reduz à metade a quantidade de cromossomos das células, dando origem as células haploides e preparando as células sexuais para a fecundação. Para Rüsse \& Sinowatz (1998), mediante a fusão de dois gametas haploides, reconstitui-se o número diploide caracteristico para cada espécie doméstica e estes estão listados no Quadro 1.

Quadro 1. Número de cromossomos em diferentes espécies de animais domésticos (Rüsse \& Sinowatz, 1998).

\section{ESPÉCIE}

Cão (Canis lupus familiaris)

Gato (Felis catus domesticus)

Equino (Equus caballus)

Bovino (Bos taurus)

Suino (Sus scrofa domesticus)

Galinha (Gallus gallus domesticus)
NÚMERO de CROMOSSOMOS

\section{8}

38

64

60

38

78
Células somáticas: são

células de organismos mulicelulares que não estão envolvidas diretamente na reprodução, exemplo disso são as células epiteliais e as musculares. O núcleo destas células são divididos apenas por mitose, cada célula somáica possui o número completo de cromossomos de acordo com a espécie, na maioria são diploides (sendo 46 cromossomos em humanos, os quais são organizado em pares).

Células germinativas: são células que por meio da meiose, em animais, podem dar origem aos gametas. A saber: 0 ovócito e 0 espermatozoide. Estas células gaméficas, originadas a parir das CGPs, apresentam a metade do número de cromossomos (haploides; 23 , em humanos).

Células-tronco: são aquelas que mantêm a capacidade de se transformar em células especializadas de um tecido qualquer do corpo. Em exemplo temos as células tronco da medula óssea de um adulto que podem dar origem a células do sangue. Já as células-tronco Embrionárias são consideradas pluripotentes e podem se diferenciar nos mais diferentes ipos teciduais, podendo ser até tofipotentes. 
Em ovos de galinha, existem determinantes citoplasmáticos de células germinativas. Eles são encontrados no polo vegetal do ovo, mais especificamente na área de endoderme.
Em animais, como os vertebrados, existe uma clara precoce na separação das células germinativas primordiais (CGPs) de tipos celulares somáticos (GILBERT, 2003). São elas que dão origem aos gametas. Estas são encontradas por exemplo, até a quarta semana de vida embrionária localizadas na parede do saco vitelino (saco que contêm o vitelo, envolvido na circulação vitelina do embrião - Figura 3). A partir de então, iniciam uma migração mediante movimentos ameboides, fixando-as na parede dorsal do como, local no qual se diferenciaram para formar as gônadas. As fases da gametogênese são marcadas pela proliferação/crescimento e maturação do embrião.

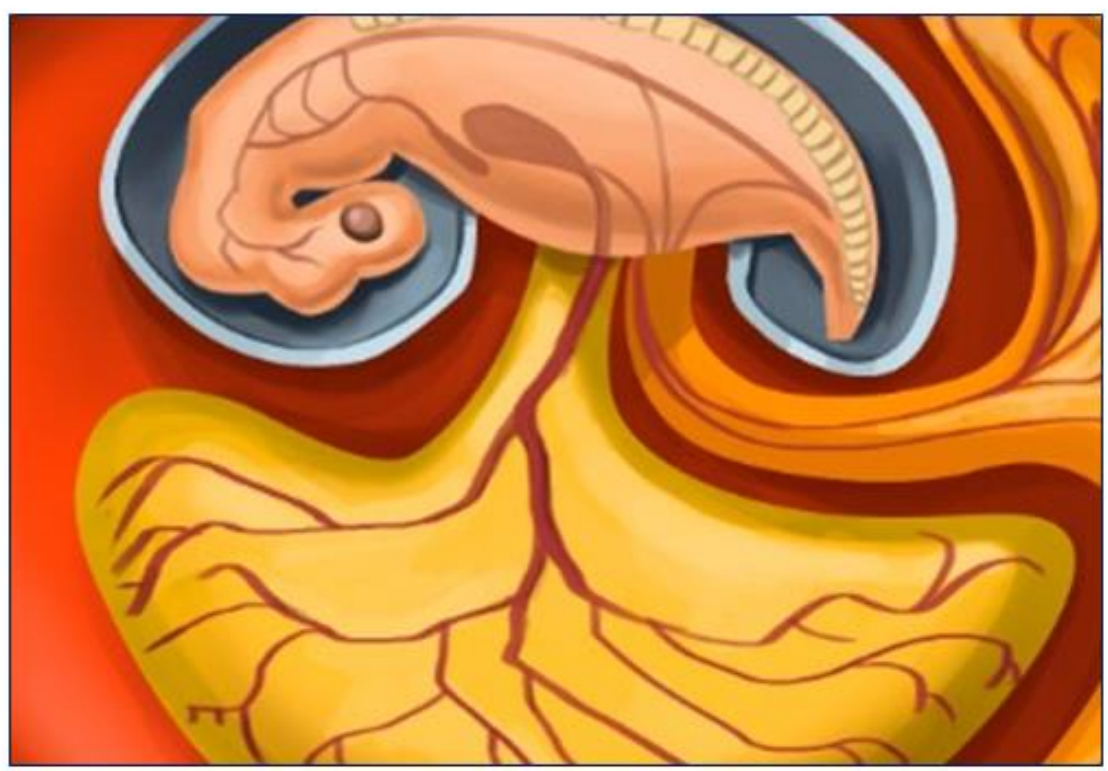

Figura 3. Esquema de um saco vitelino (em amarelo) envolvido na circulação do embrião em desenvolvimento, estrutura attamente vascularizada. Fonte: Assunção (2020).

\section{Mitose}

Conhecida como a fase de divisão celular, a mitose apresenta seu número de cromossomos divididos entre as células-filhas, igualmente. $O$ processo pelo qual o núcleo de uma célula dá origem a um novo núcleo a cada célula-filha é denominado de cariocinese, sendo acompanhado também pela divisão citoplasmática conhecida como citocinese (HYTTEL; SINOWATZ \& VEJLSTED, 2010).

A cariocinese junto a citocinese resultam em duas células-filhas que são idênticas quando comparadas geneticamente às suas células progenitoras, cada uma neste caso, recebe um complemento cromossômico diploide completo. 


\subsection{Fases da Mitose}

A mitose apresenta-se subdividida em 5 diferentes fases, a saber: interfase, prófase, anáfase e telófase. Especificamente, na fase de interfase para prófase, seus cromossomos se enovelam, se contraem e apresentam-se de forma mais espessa. Assim, os nucléolos na fase de prófase desapareœm e as cromatinas tornam-se mais visiveis a partir do momento em que se condensam. Após o afastamento dos centrossomos ocorre o inicio da formação do fuso mitótico o qual é constituido por microtúbulos e proteinas associadas, quando duplicados, surgem as cromátides-irmãs ligadas pelos centrômeros e ao longo dos braços.

No decorrer da progressão da fase de prófase para a metáfase (estágio esse também conhecido como prometáfase), dois pares de centriolos começam a se formar e o envelope nuclear sofre uma desorganização estrutural. Neste momento, parte dos microtúbulos vindos de polos opostos da célula fixam-se sua estrutura nas cromátides, os cinetócoros, localizados no centrômero de cada cromossomo. Tal ocorrência passa a estabelecer o fuso mitótico contendo um par de centriolo em cada polo da célula. A medida que o fuso mitótico se forma, os cromossomos se alinham no plano equatorial da célula, definindo a metáfase da divisão celular.

Posteriormente, os centrômeros de cada cromossomo passa pelo processo de divisão, aqui, suas duas cromátides submetidas à tração ocasionada pelos microtúbulos, se separam. A partir dai, estas começam a migrar-se em direção aos polos do fuso mitótico durante a anáfase. Nessa fase, a célula alonga-se e as suas extremidades apresentam conjuntos duplos de cromossomos em cada polo do fuso, estabelecendo a fase de telófase da divisão celular.

Continuando na fase de telófase, os cromossomos tornam-se menos condensados e se desenovelam formando os núcleos celulares e o envelope nuclear se reorganiza em cada uma das células-filhas em formação. Com isso, os microtúbulos do fuso mitótico desaparecem e a mitose finda seu processo. Em células animais, ocorre a formação do sulco de clivagem, que divide a célula em duas.

Os eventos descritos acima que contempla a fase da mitose bem como a ocorrência do fuso mitótico, podem ser observados de forma detalhada na figura 4 apresentada a seguir. 

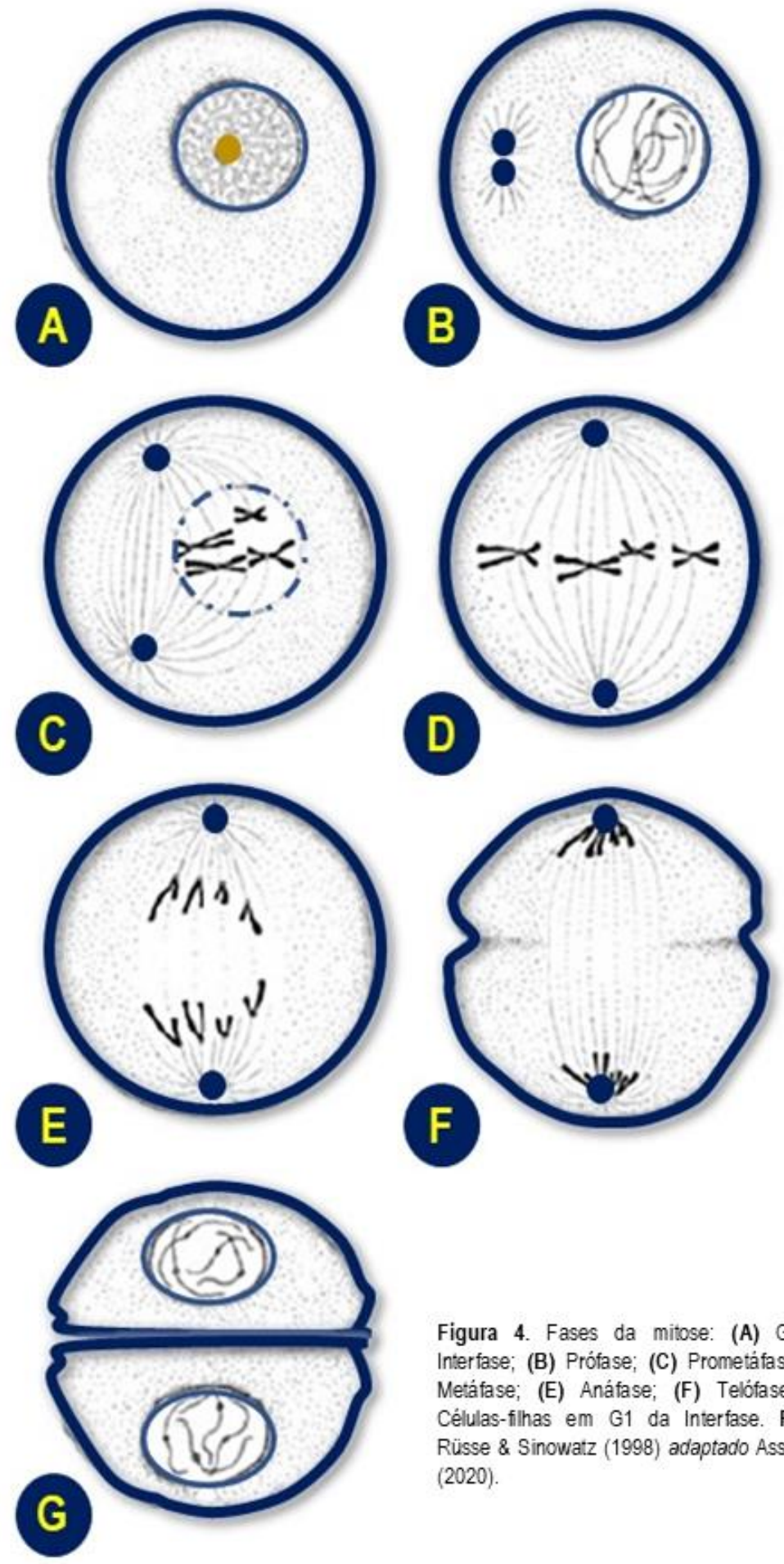

Figura 4. Fases da mitose: (A) G2 da Interfase; (B) Prófase; (C) Prometáfase; (D) Metáfase; ( $E$ ) Anáfase; ( $F$ ) Telófase; (G) Células-filhas em G1 da Interfase. Fonte: Rüsse \& Sinowatz (1998) adaptado Assunção (2020). 


\section{Meiose}

A meiose é definida pelo processo que envolve duas divisões œelulares que são especializadas, ou seja, meiose I (ou reducional) e a meiose II (ou equacional). Uma vez na gônada, as células germinativas primordiais (CGPs) continuam a sua divisão mitótica. Estas produzem milhões de gametas potencializados. Estes gametas nos machos são comumente conhecidos de espermatogônias (espermatozoide) enquanto nas fêmeas são denominados ovogônias (oócito).

No entanto, em um determinado momento, as células das gônadas necessitam reduzir seu número de cromossomos. Isso ocorre tanto nos machos quanto nas fêmeas, passando da condição diploide para haploide. Vale destacar que além da produção de gametas haploides que ocorrem na meiose, outro evento de extrema importância é a recombinação gênica; este processo garante que genomas de gerações futuras sejam combinações exclusivas de genomas parentais.

As divisões meióticas inclui as mesmas fases transcorridas na mitose, sendo estas, as fases dê: prófase, metáfase, anáfase e telófase. Na meiose II a fase de prófase não ocorre. Já na meiose I ocorre o processo mais complexo devido a prolongação da prófase fazendo com que esta seja subdividida em diferentes estágios. Estes estágios, são: leptóteno, zigóteno, paquiteno, diplóteno e a diacinese; os nomes dados a cada um destes estágios estão de acordo com a aparência morfológica dos cromossomos. A célula materna passa a se chamar ovócito primário após as células germinativas iniciarem a meiose I. Já as células paterno gênicas são denominadas de espermatócito primário.

Bloqueada no estágio diplóteno da meiose I até a puberdade, o inicio da meiose na fêmea ocorre durante a vida fetal do individuo, e, é reiniciada pouco antes da ovulação. Por sua vez, o inicio da meiose no macho inicia-se após a puberdade em um processo continuo. Com relação ao intercâmbio de segmentos cromossômicos e a recombinação gênica, sugiro a leitura do Capitulo 4 do livro "Embriologia Veterinária" dos autores Poul Hyttel, Fred Sinowatz e Morten Vejlsted, pag. 38-40, 2010.

\author{
Em humanos, há 23 \\ diferentes pares de \\ cromossomos. Com isso, \\ podem haver 233 diferentes \\ ipos de células do tipo \\ haploide que são formadas \\ por meio do genoma de um \\ único individuo. Além disso, \\ o processo de intercâmbio \\ de segmentos \\ cromossômicos (crossing- \\ over), que ocorrem durante \\ os estágios paquiteno e \\ diplóteno da prófase I, \\ aumentam gradasvamente \\ a diversidade genômica. \\ Com isso, o número de \\ gametas apresentam-se \\ diferentes e em grande \\ quanidade, tornando-0 \\ incalculável.
}


As ovogônias e as espermatogônias que são células germinativas que pertencem a fêmea $\mathrm{e}$ ao macho, passam pela fase $\mathrm{S}$ do ciclo celular antes mesmo de iniciar a meiose formando duas cromátides em cada um dos cromossomos, assim como ocorre na mitose. O estágio de leptóteno da prófase em meiose l é o estado da célula germinativa (Figuras $5 \mathrm{e} 6$ ).

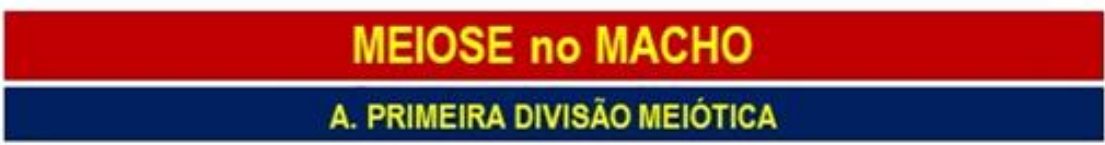
Complexo

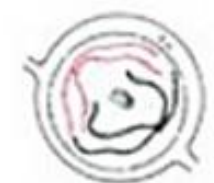

Conclusão da Fase S

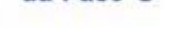 \\ Separação dos Cromossomos Homólogos}

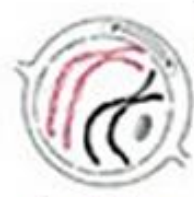

Leptóteno Sinaptonêmico
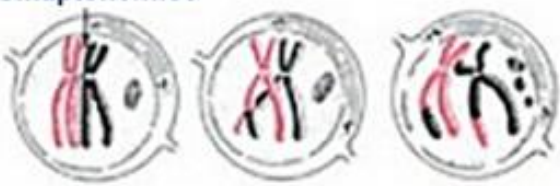

Zigóteno

Paquiteno (Crossing-over)

Espermatócito Primário
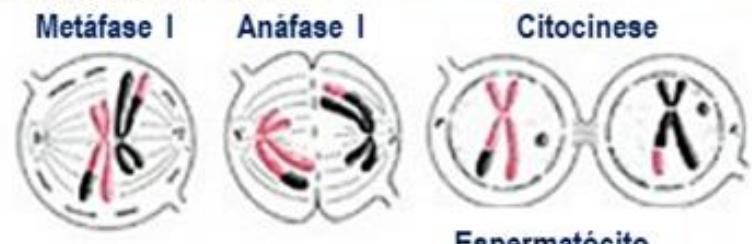

Espermatócito Secundário

\section{B. SEGUNDA DIVISÃO MEIÓTICA}

O estágio de diplóteno é caracterizado por um ato nivel de transcrição gênica. Em determinadas espécies, os cromossomos, tanto de células germinafivas dos machos quanto das fêmeas passam a desenvolver as caracteristica dos cromossomos que estão asvamente produzindo 0 RNA.

O paquiteno (crossing-over) representa trocas de material genésco por meio dos genes de uma cromáside. Estes são trocados por genes homólogos de outra cromásde.

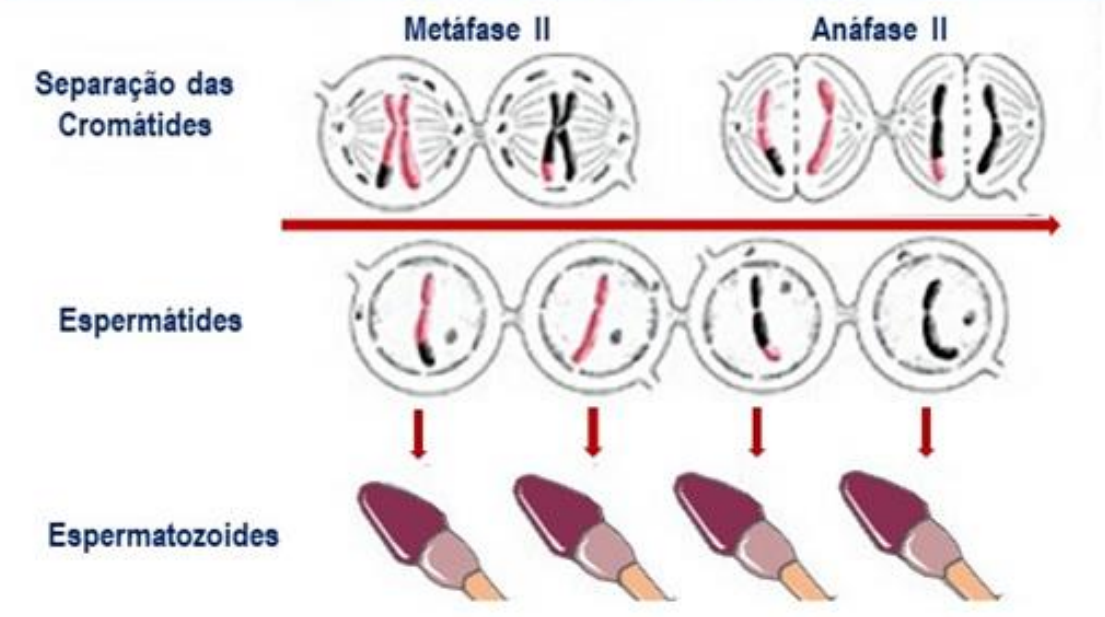

Figura 5. Fases da meiose no individuo macho. Fonte: Rüsse \& Sinowatz (1998) adaptado Assunção (2020). 


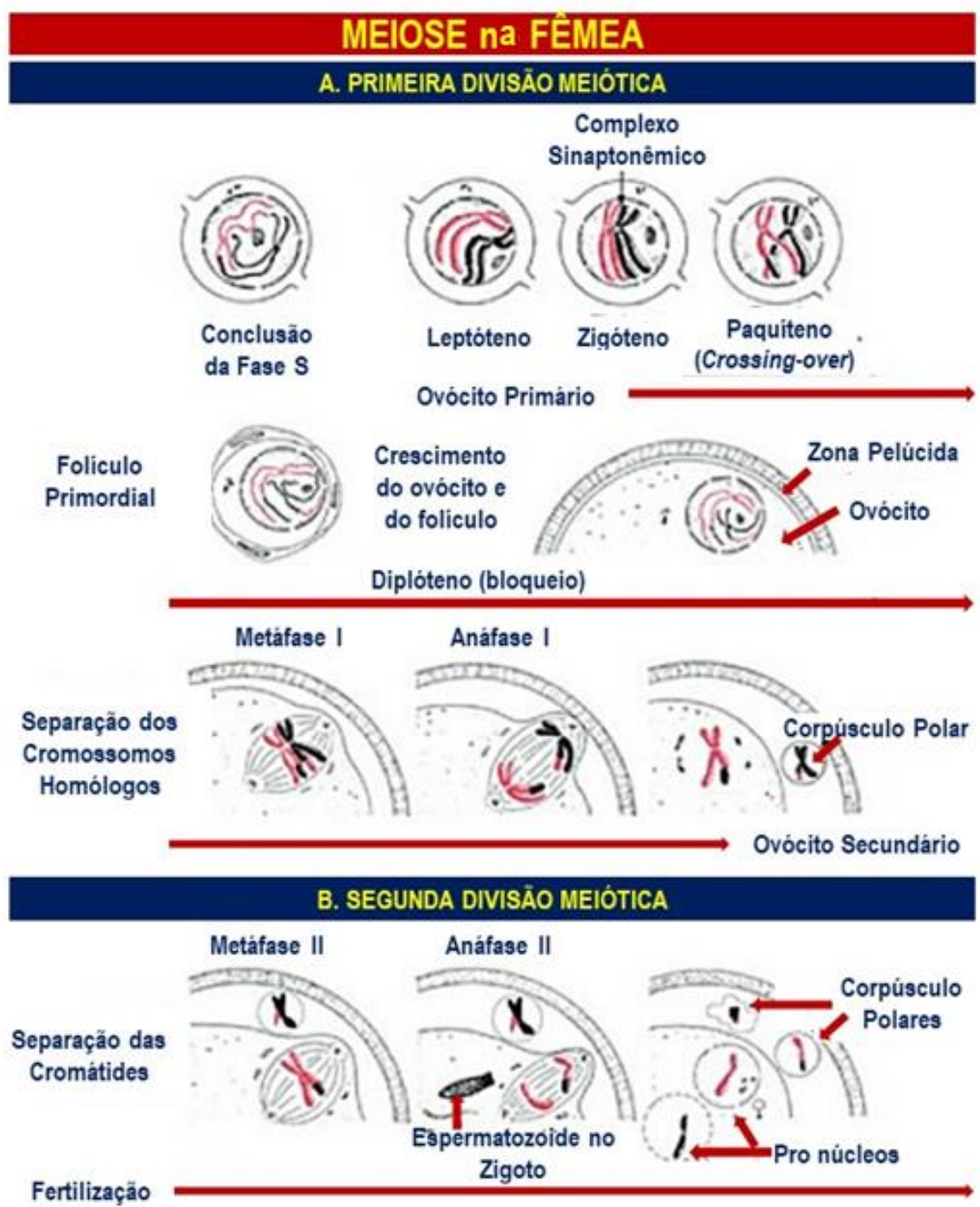

Figura 6. Fases da meiose na fêmea. Fonte: Rüsse \& Sinowazz (1998) adaptado Assunção (2020).

\section{Espermatogênese}

A espermatogênese é o evento fundamental e responsável pelo desenvolvimento das espermatogônias que ocorrem nos túbulos seminiferos (túbulos enovelados; localizados no interior da bolsa escrotal). O termo espermatogênese é utilizado para todo e qualquer processo que envolve a formação dos gametas já em fase de maturação nos machos, a partir das células germinativas primordiais (CGPs).
Na citodiferenciação, a meiose provê os gametas com o número haploide de cromossomos possibilitando com isso, a recombinação gênica. No entanto, há uma necessidade de construção de uma arquitetura celular especializada que caracterize os dois gametas. Neste processo de citodiferenciação ocorrea formação dos ovócitos das ovogônias por meio da ovogênese $e$ espermatozoides de espermatogônias por meio da espermatogênese (HYTTEL; SINOWATZ \& VEJLSTED, 2010). 
Em animais como os mamiferos, as gônadas surgem no decorrer do desenvolvimento embrionário, mas só se proliferam quando estão próximas a atingir o estágio de maturidade sexual. Para além disso, é possivel observar neste momento a rápida multiplicação das CGPs por mitose, configurando o que é conhecido como células somáticas epiteliais. Estas estão localizadas em cordões sólidos compostos por células de sustentação primitivas, ou seja, as progenitoras das células de Sertoli.

Antes de atingir a puberdade, os cordões celulares sólidos também conhecidos como cordas sexuais tornam-se ocas, adquirem uma luz que resulta na formação dos túbulos seminiferos dos testiculos. A partir de então, o epitélio dos túbulos seminiferos passa pelo processo de diferenciação, e, gradualmente ganham caracteristicas das células de Sertoli dando inicio a espermatogênese, onde as CGPs tornam-se espermatogônias (Figura 7).

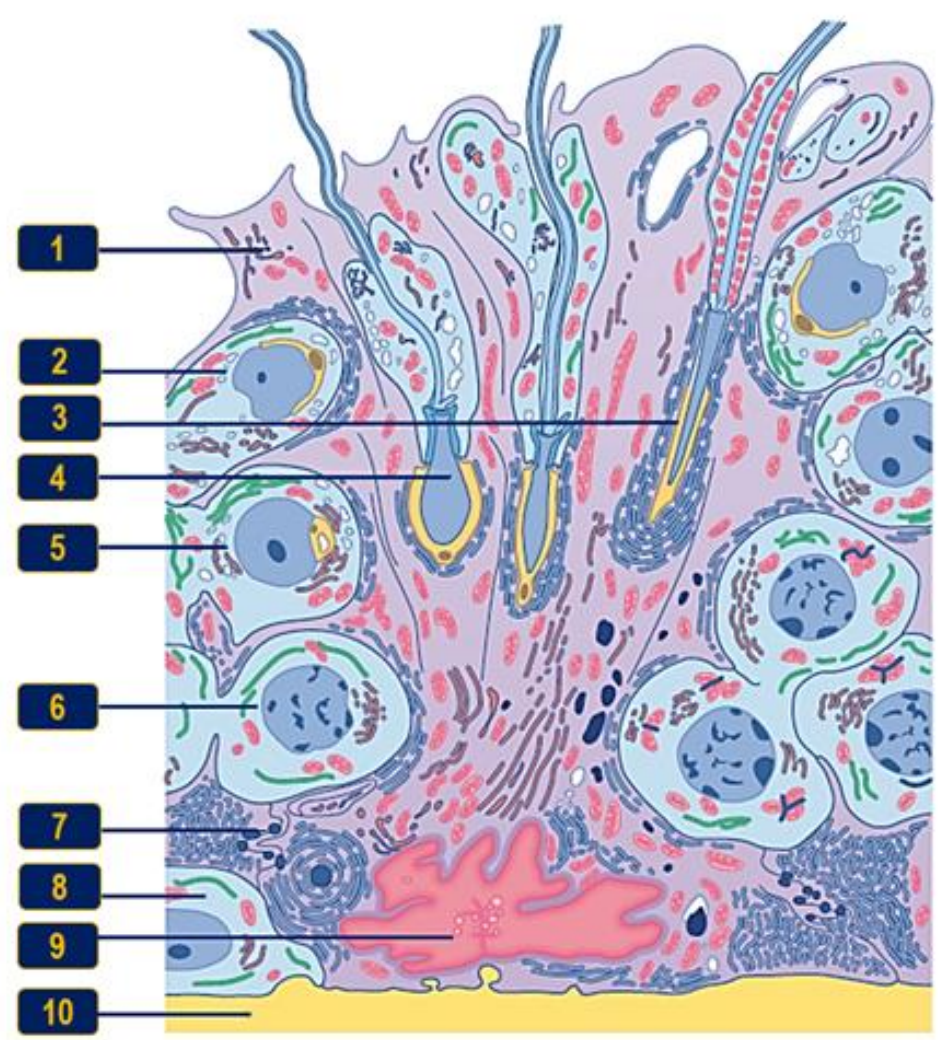

Figura 7. Célula de Sertoli e Células espermatogênicas presentes nos túbulos seminiferos do testiculo. (1) Células de Sertoli; (2) Espermátide - Fase de Capuchão; (3) Espermátide - Fase de maturação; (4) Espermásde - Fase de acrossomo; (5) Espermátide - Fase de Golgi; (6) Espermatócitos primários conectados por pontes citoplasmáticas; (7) Barreira hematotesticular; (8) Espermatogônias; (9) Núcleo da célula de Sertoli; (10) Lâmina basal. Fonte: Liebich (2004) modificado Hyttel et al., (2010) adaptado Assunção (2020). 
A espermatogênese é um processo embriológico que inclui todos os eventos que antecede a formação do espermatozoide por meio das espermatogônias. № entanto, pode ser subdividido em espermatocitogênese (que compreende o desenvolvimento dos espermatócitos e das espermatogônias), meiose (que compreende as duas divisões meióticas dos espermatócitos) e a espermiogênese (que compreende a reestruturação celular das espermátides em espermatozoides sem nenhuma divisão celular).

\section{Ovogênese}

A ovogênese compreende o desenvolvimento dos foliculos primordiais. Neste estágio as células germinativas primordiais são circundadas por células foliculares (células somáticas achatadas derivadas do epitélio superficial do ovário) que transformam as células germinativas primordiais em ovogônias, as quais continuam a se proliferar (Figura 8).

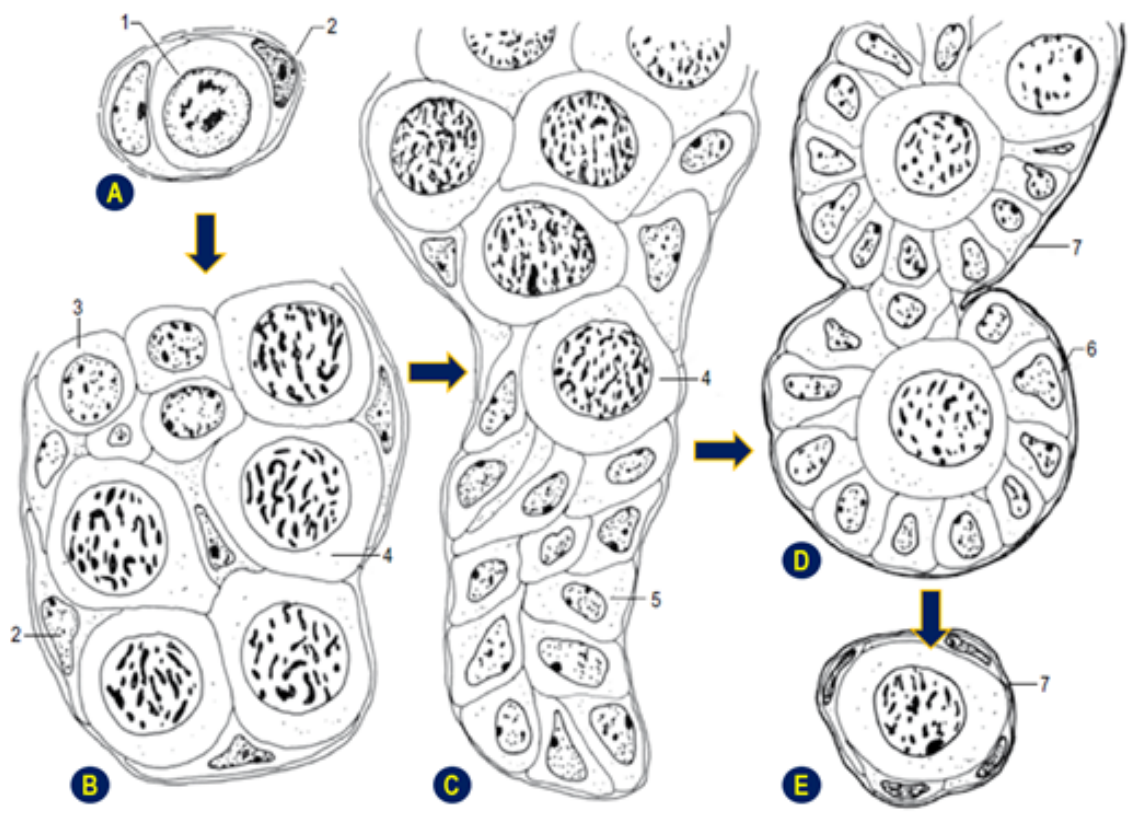

Figura 8. Foliculo primordial em estágio de desenvolvimento. (A) Célula germinafiva primordial (CGP) 1/2) Circundada por células pré-foliculares. (B) Aglomerado de ovogônias - 3) e ovócitos; 4) associados a células pré-foliculares. (C) Mulifilicação das células foliculares - 5. (D) Desenvolvimento das células préfoliculares em células foliculares - 6) circundadas pela lâmina basal; 7 -e associadas a ovócitos individuais. (E) O foliculo primordial final isolado. Fonte: Rüsse \& Sinowaz (1998). 
O tempo necessário para uma espermatogônia tornar-se um espermatozoide varia de espécie para espécie. № camundongo,

aproximadamente 35 dias. OS estágios da espermatogênese duram oito dias; a meiose, 13 dias, e a espermiogênese gasta em média 14 dias (GILBERT, 2003). Em humanos, o estágio é de aproximadamente 64 dias (SANDLER, 2005). Cerca de 100 milhöes de espermatozoides são produzidos em cada tesículo Humano por dia, e cada ejaculação liberta cerca de 200 milhöes de espermatozoides. Na vida, um homem pode produzir de 1012 a 1013 gametas. Quando não ejaculados, esses são reabsorvidos ou eliminados do organismo pela urina.
O crescimento folicular e oocitário (ocorre quando os foliculos são recrutados da reserva primordial e se desenvolvem em folículos: primários, secundários e terciários). Nas espécies domésticas, tais como nos "bovinos, suinos, equinos, caninos e felinos ${ }^{*}$ o crescimento folicular é iniciado durante a vida fetal, periodo no qual as células foliculares passam a ser chamadas de granulosas. A partir desta fase, o crescimento ovocitário (que ocorre na ovogônia) é iniciado, de maneira que o ovócito das espécies antes mencionadas por exemplo, cresce de menos de $30 \mu \mathrm{m}$ para mais de $120 \mu \mathrm{m}$ de diâmetro). A partir dai ocorre a posterior maturação tanto folicular quanto ovocitária (transformação ovócito em óvulo nas fêmeas).

A espermatogênese é um processo embriológico que inclui todos os eventos que antecede a formação do espermatozoide (Figura 9) por meio das espermatogônias; vale considerar que o tamanho do espermatozoide a partir do momento que é liberado pode variar de 60 a $75 \mu \mathrm{m}$ de acordo $œ m$ a espécie. No entanto, pode ser subdividido em espermatocitogênese (que compreende o desenvolvimento dos espermatócitos e das espermatogônias), meiose (que compreende as duas divisões meióticas dos espermatócitos) e a espermiogênese (que compreende a reestruturação celular das espermátides em espermatozoides sem nenhuma divisão celular).

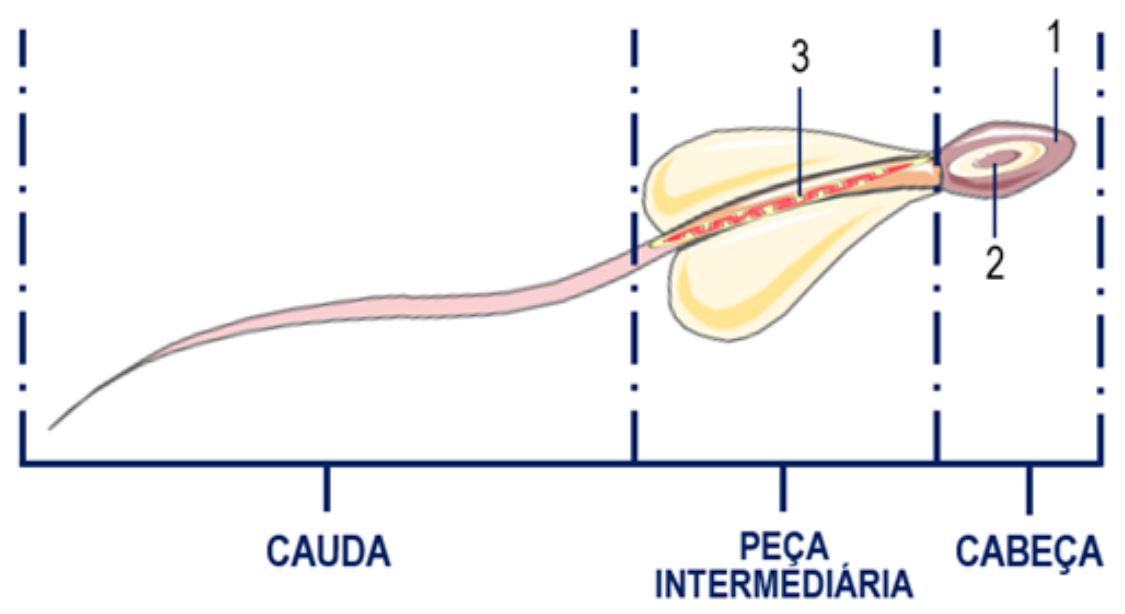

Figura 9. Representação da estrutura geral de um espermatozoide após seu processo de formação. (1) Acrossomo. (2) Núcleo. (3) Mitocôndria. Fonte: Assunção (2020). 
A fase de proliferação é responsável pela formação de células gaméticas, ou seja, da ovogônia; na fase de crescimento ocorre a formação dos ovócitos e na maturação, a liberação do ovócito nas fêmeas. Nos machos, o crescimento e a maturação ocorrem o tempo inteiro. Portanto, em um encontro dos gametas do macho e da fêmea (que ocorre na tuba uterina) dá origem à formação do zigoto, iniciando, portanto, a formação embrionária.

\section{Ciclo Reprodutivo e Ciclo Estral}

A ovocitogênese possui um processo bem mais complexo quando comparado com a espermatogênese. Em individuos machos, é na puberdade que a espermatogênese inicia, já a ovocitogênese ocorre de forma precoce na vida intrauterina com a formação do oócito que aparece na puberdade. $\mathrm{O}$ inicio desta é regulado por mudanças e ajustes na liberação de hormônios. No caso em especifico de recém-nascidos, o oócito apresenta apenas uma camada de células foliculares que possibilita a formação do foliculo primordial.

Nas fêmeas, modificações que ocorrem ao longo do desenvolvimento podem gerar mudanças morfológicas no ovário. Com essas mudanças, foliculos ovarianos surgem (Figura 10) e os oócitos primários se modificam. Com isso, o sistema reprodutor da fêmea passa a estar preparado para a fecundação, consequentemente, para a gestação, no caso dos mamiferos.

As modificações que ocorrem no sistema reprodutor da fêmea denomina-se ciclo reprodutivo. O ciclo menstrual é denominado para os primatas, enquanto que o estral para animais domésticos, a saber: cadela, gata, porca, vaca, égua, galinha, etc Didaticamente, o ciclo estral compreende quatro fases: proestro, estro ou cio, metaestro e diestro. O periodo de duração dos ciclos menstrual e estral varia de acordo com a espécie (Quadro 2).

Portanto, a variação do tempo para cada ciclo reprodutivo pode ser influenciada por diferentes fatores como por exemplo, hormonais, temperatura, estresse, nutrição, sendo este ultimo prestigioso quando envolve os animais domésticos.
A meiose ovocitogênica presente no decorrer da formação ovocitária, conserva o volume citoplasmático do oócto em um único tipo celular ao invés de dividi-lo igualmente entre quatro tipos de progenitores.

Puberdade: periodo que machos e fêmeas são capazes de excretar gametas e exibir comportamento sexual. 


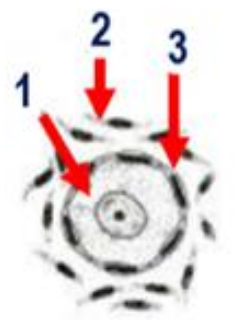

A

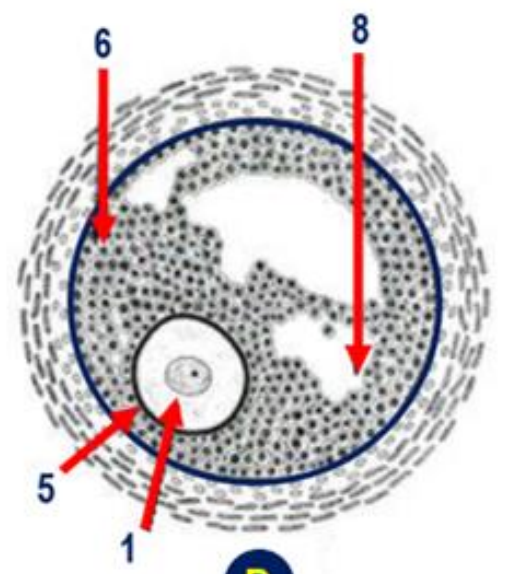

D

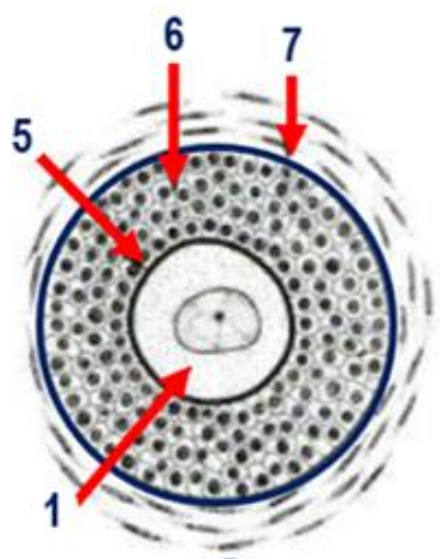

C)

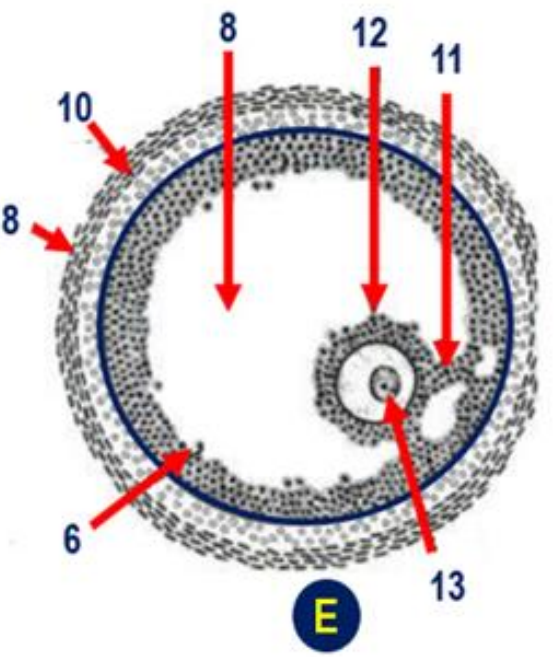

Figura 10. Representação dos foliculos ovarianos em diferentes fases do desenvolvimento embrionário. (A) Foliculo primordial. (B) Foliculo primário. (C e D) Foliculos secundários (ou de crescimento). (E) Foliculo terciário. 1 - Ovócito primário; 2 - Tecido conjuntivo do ovário; 3 - Células foliculares achatadas; 4 - Células foliculares cúbicas; 5 - Membrana pelúcida; 6 - Célula granulosa; 7 - Envolório externo do foliculo (ou teca); 8 - Antro folicular; 9 - Teca externa; 10 - Teca interna; 11 - Células do Cumulus oophorus; 12 - Células da corona radiata; 13 - Ovócito secundário. Fonte: FMRP/USP adaptado Assunção (2020). 
Quadro 2. Duração e tipo de ciclo reprodutivo nas diferentes espécies de animais domésticos. Fonte: Assunção (2020).

\begin{tabular}{|c|c|c|}
\hline ANIMAL & DURAÇÃO do CICLO & TIPO de CICLO \\
\hline Cadela & 6 meses & Estral \\
\hline Gata & 14 a 21 dias $^{\star \star \star}$ & Estral \\
\hline Porca & $19-21$ dias & Estral \\
\hline Vaca & 21 dias & Estral \\
\hline Égua & $19-25$ dias & Estral \\
\hline Galinha & $25-26$ horas & Ovariano \\
\hline
\end{tabular}

Legenda: ** répteis aves em postura estão sempre receptivas aos machos. Há nova ovulação após a postura do ovo e a formação do ovo requer cerca de 25 horas, portanto, as modificaçäes do aparelho reprodutor se restringem basicamente ao ovário, por isso, chama-se ciclo ovariano em répteis aves; "*t variável, apresenta ovulação induzida, dependente da ocorrência da cópula, portanto sem cópula há a tendência de aumento da fase do estro.

\section{Atividades}

a) Qual a relevância da gametogênese?

b) Descreva, brevemente, a ovocitogênese e a espermatogênese.

c) Faça um paralelo entre ciclos menstrual e estral.

d) Cite as caracteristicas principais do espermatozoide.

e) 0 epitélio dos túbulos seminiferos passa pelo processo de diferenciação e gradualmente ganham caracteristicas das células de Sertoli. Após este processo inicia-se um dos eventos fundamentais no desenvolvimento embrionário, cite e defina-o. 


\section{Referências}

GILBERT, S. F. Determinação do sexo. In: Biologia do desenvolvimento. 5. ed. São Paulo: FUNPEC, 2003. p. 773-804.

HYTTEL, P.; SINOWATZ, F. \& VEJSTED, M. Domestic Animal Embryology. 11th ed. Saunders, Elsevier, p.359. 2010.

LIEBICH, H.G. Funktionelle Histologie der Haussaugtiere. Schatter, Stuttgart, Germany. 2004.

RÜSSE, I. \& SINOWATZ, F. Lehrbuch der Embryologie der Haustiere, 2nd edn. Parey Buchverlag, Berlin. 1998

SADLER, T. W. Langman Embriologia Médica. 9a edição. Editora GuanabaraKoogan, Rio de Janeiro, 2005. 

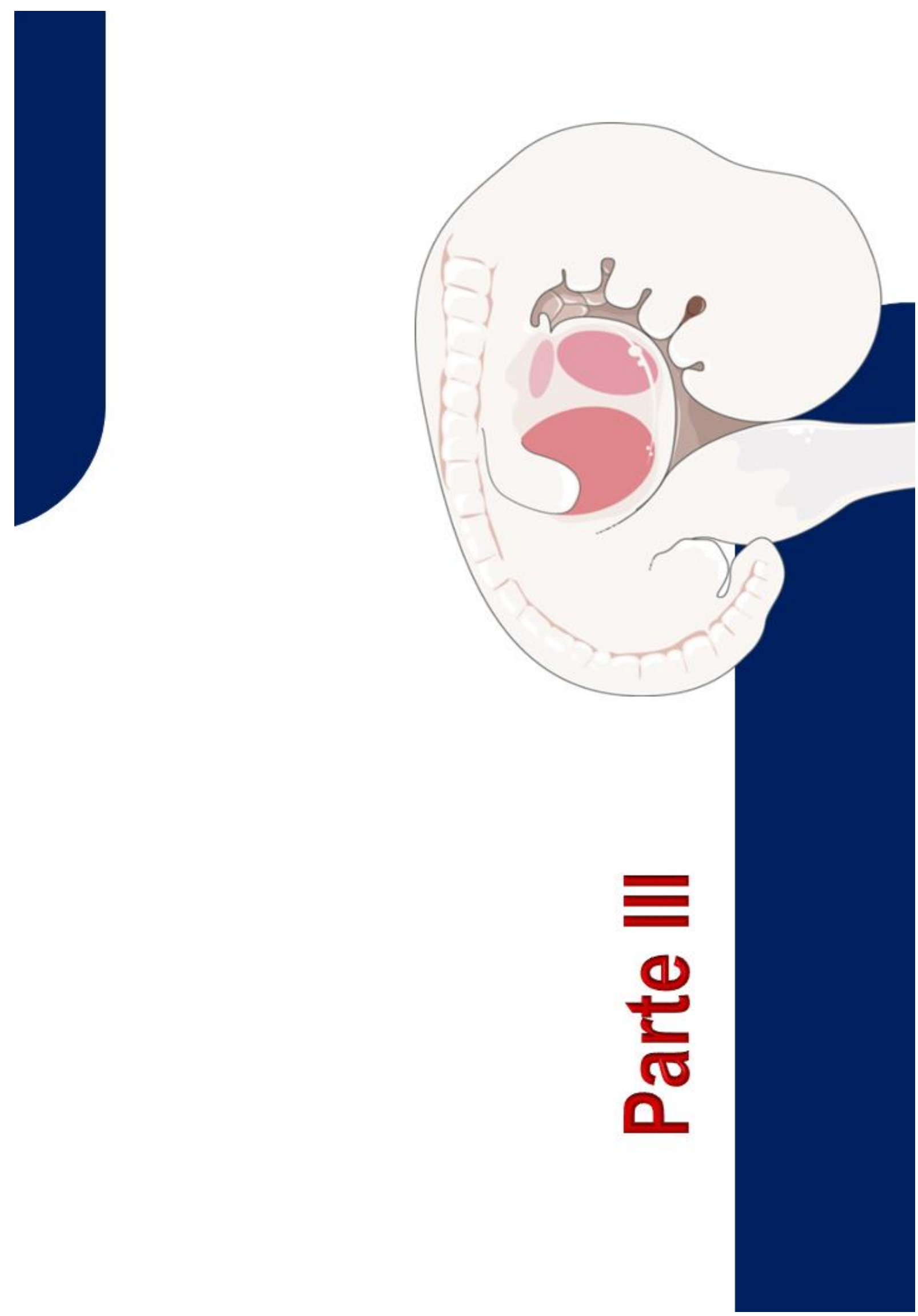


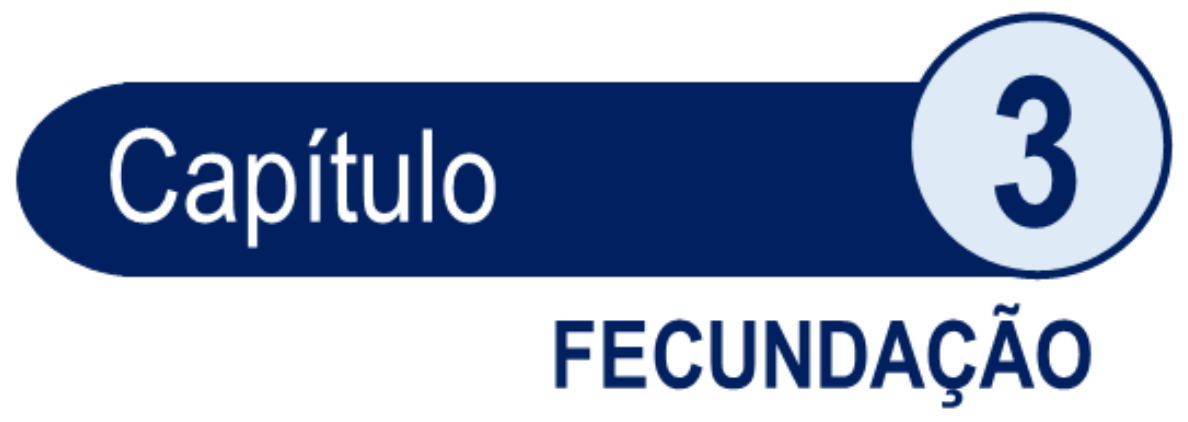

\section{Introdução e Conceitos Gerais}

O desenvolvimento embrionário, ou seja, a reprodução sexuada ocorre por meio da fecundação (ou fertilização). Verticalizando para a Embriologia de fato, é neste processo que os gametas haploides do macho (espermatozoide) e da fêmea (oócito), se unem na tuba uterina, mais especificamente na região da ampola (em mamiferos), dando origem a um organismo unicelular diploide, o zigoto. As estruturas envolvidas no processo de fecundação em aves (Gallus gallus domesticus) podem ser observadas na Figura 11.

A priori, a combinação gênica que ocorre entre o pai e a mãe para a formação da prole, ativa o processo de desenvolvimento citoplasmático do ovo mamifero o qual a partir de diversas reações mitóticas, o zigoto transforma-se em um organismo pluricelular a partir de divisões, movimentações, crescimentos e modificações celulares.

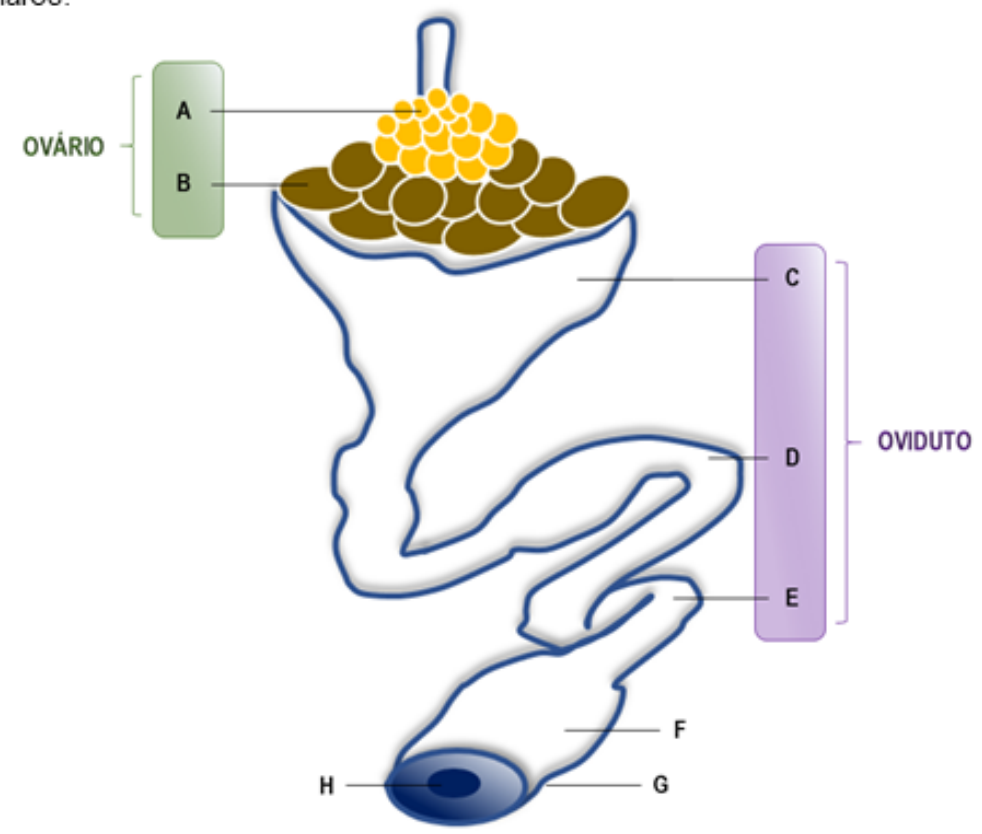

Figura 11. Esquema do sistema reprodutor da galinha. (A) Óvulos imaturos. (B) Gema (ou vitelo). (C) Infundibulo. (D) Magno. (E) Istmo. (F) Útero. (G) Vagina. (H) Cloaca. Fonte: Assunção (2020). 
Independente do grupo animal, o complexo formado pelo ovo mamifero, apresenta caracteristicas que classifica seus componentes (Quadro 3).

Quadro 3. Classificações principais do complexo formado pelo ovo mamifero segundo Hyttel (2010). Fonte: Assunção (2020).

\begin{tabular}{|c|c|}
\hline COMPONENTES & CARACTERISTICAS \\
\hline Ovócito (ou oócito) & $\begin{array}{c}\text { Na maioria dos animais domésticos } \\
\text { (exceto cães), o oócito é encontrado } \\
\text { aderido na fase de metáfase da meiose } \\
\text { II. }\end{array}$ \\
\hline Zona Pelúcida & $\begin{array}{c}\text { Matriz extracelular (MEC) que envolve o } \\
\text { oócito. Na sua constituição há } \\
\text { glicoproteinas e estas são sintetizadas } \\
\text { tanto pelo oócito quanto pelas células de } \\
\text { cumulus presente, em geral, nos animais } \\
\text { domésticos. }\end{array}$ \\
\hline Células do Cumulus & $\begin{array}{c}\text { Composta por várias camadas de células } \\
\text { do Cumulus oophorus presentes na } \\
\text { MEC. Em sua constituição destaca-se o } \\
\text { ácido hialurônico, um dos componentes } \\
\text { da MEC. }\end{array}$ \\
\hline
\end{tabular}

Segundo Gilbert (2003) o reconhecimento e o contato que ocorre entre o espermatozoide e o óvulo de uma mesma espécie animal, torna-se fundamental para a regulação da fecundação. Caso haja a regulação do contato, apenas um

É necessário que 0 espermatozoide vença as barreiras do oócito consfiluidas pela "corona radiata" e zona pelúcida - ZP (matriz extracelular que circunda 0 oóctio e 0 embriäo inicial).
A zona pelúcida $(Z P)$ e 0 oócito são comumente considerados como estruturas únicas, levando a descrição do complexo formado pela ovulação (COC) quando pensado aos processos biotecnológicos. espermatozoide consegue ganhar o óvulo (monospermia), inibindo a entrada de outro qualquer (polispermia). Anfimixia é a denominação dada para a fusão do material genético tanto do espermatozoide quanto do óvulo. Neste contexto, após a complexidade dos eventos que aqui ocorrem, é necessário considerar ainda que para a ocorrência do desenvolvimento embrionário, a ativação do metabolismo ovocitário é primordial.

\section{Fases da Fecundação}

Após atingir a "corona radiata", o espermatozoide libera uma enzima digestiva que promove o rompimento da zona pelúcida, permitindo que o espermatozoide entre no oócito. Ao ganhar o oócito, o espermatozoide atinge a membrana plasmática, determinando as fases da fecundação. 
A primeira fase da fecundação é denominada de singamia. Essa fase nada mais é do que a adesão e fusão da membrana plasmática do espermatozoide com a membrana plasmática do oócito. Após a penetração na zona pelúcida, o segmento equatorial do espermatozoide adere-se e funde-se à membrana plasmática do oócito. É exatamente a partir dessa fusão, que o núcleo do espermatozoide é liberado dentro da célula.

Após a entrada do núcleo na célula, a membrana plasmática do oócito se fecha de maneira que a penetração de outros elementos é impedida, e apenas um único núcleo de um único espermatozoide entre os milhares que estavam ali, consegue romper a barreira e adentrar a membrana plasmática do oócito. Então, a primeira fase da fecundação é a singamia: fusão das membranas plasmáticas tanto do ovócito quanto do espermatozoide.

A segunda fase é denominada de cariogamia (cario = núcleo; gamia = junção), ou seja, é a fusão dos núcleos. É nesta fase que o núcleo do espermatozoide se encontra com o núcleo do oócito, e ambos se fusionam. Agora, com os 23 cromossomos do espermatozoide mais os 23 cromossomos do oócito, misturam-se os DNA's (este número de cromossomos é aquele referente à espécie humana).

Nos animais domésticos, o número de cromossomos é variável de acordo com a espécie, dando origem a uma única célula a qual chamamos de zigoto. Esse zigoto é a célula $2 n$, sendo um $n$ que se originou do espermatozoide e outro $n$ que se originou do oócito. Depois que núcleo ganha o interior da célula, o oócito finda a divisão celular, findando também a meiose II.

Estruturalmente, existem mitocôndrias situadas próximo a cauda dos espermatozoides. Essas mitocôndrias não entram no oócito. Elas permanecem do lado de fora. A única estrutura que adentra é o núcleo e o restante (digamos assim) tomam o finito (ficam tudo para trás).

Em geral, os machos pertencentes às espécies domésticas por exemplo, não colaboram œm as suas mitocôndrias. Logo todas as mitocôndrias presentes na œélula ovo formada (o zigoto), são mitocôndrias maternas, ou seja, aquelas que vieram da mãe, para as quais denominamos de herança mitocondrial.

\section{Estrutura dos Gametas}


Em mamiferos, os espermatozoides contém uma proteina denominada ferlina em sua membrana, esta é essencial para que ccorra a fusão espermatozoide-oócito. A proteina tem ação hidrofóbica semelhante às das proteinas fusogênicas virais, além de uma sequência que sugere ligação com uma integrina da membrana do oócito, a região hidrofóbica da ferflina media a união das duas membranas (GILBERT, 2003).
O espermatozoide e o oócito são células especializadas e consideradas fundamentais na Embriologia para que ocorra a fecundação. Ressaltando, cada célula sexual madura (gameta) em sua constituição, contém apenas a metade do conteúdo genético de sua espécie, sendo $n$ haploide.

Entre as espécies de animais vertebrados, os oócitos originados, apresentam caracteristicas estruturais que são similares em relação ao seu núcleo bem œmo às conteúdos citoplasmáticos e envoltórios. Em geral, os núcleos possuem uma grande quantidade de vesiculas e são particularmente grandes, com exceção dos mamiferos que apresentam uma grande quantidade de nucléolos. A primeira divisão meiótica que ocorre no oócito em animais domésticos por exemplo, só finda seu processo no momento em que antecede a ovocitação. A partir disso, por ocorrência da fecundação, a meiose II é finalizada.

O citoplasma destas células em sua constituição apresenta uma reserva nutritiva composta por fosfolipidios, glicidios, gorduras neutralizantes e proteinas. A quantidade de vitelo presente no citoplasma vai de acordo œm a espécie, ou seja, a quantidade presente em uma dada espécie pode variar em detrimento de outra. Como exposto no capitulo 2 (Gametogênese) deste módulo, o vitelo é considerado como essencial na classificação dos gametas advindos da fêmea.

Gilbert (2003) reporta que o oócito apresenta uma estrutura delicada acima da membrana plasmática (MP) denominada de envoltório vitelinico. $\mathrm{O}$ autor destaca a importância deste envoltório para a ligações que ocorrem entre espécie-especificas do espermatozoide. Nos mamiferos, o envoltório vitelinico (ou membrana vitelinica) é denominada ZP e mais externamente uma camada de células aderentes são observadas e estas são oriundas do foliculo ovariano, a corona radiata (também apresentado no capitulo 2 deste modulo).

A passagem do espermatozoide pelas células da corona radiata se dá pela ação enzimática da hialuronidase liberada pelo acrossomo, esta enzima promove a dispersão da células foliculares, outros fatores como o flagelar e enzimas presentes na região da tuba uterina também podem ativar a liberação da hialuronidase (MOORE \& PERSAUD, 2008). Os vertebrados apresentam espermatozoides com diversas formas, mas três são as estruturas básicas, a saber: cabeça contendo núcleo e acrossomo, uma porção intermediária com presença de mitocôndrias que fornece 
FECUNDAÇÃO

energia no processo embrionário e uma cauda (ou flagelo) fundamental no impulso da célula. Com isso, a fecundação por meio do processo que o espermatozoide ganha o oócito, possibilita e restabelece a diploidia cromossômica, ativa o óvulo e garante a monospermia. O desenvolvimento do embrião é iniciado após este processo, no entanto, três são os eventos para que ocorra o contato espermatozoide-oócito (Quadro 4).

Quadro 4. Eventos criticos considerados no processo de fecundação dos mamiferos segundo Hafez \& Hafez (2004). Fonte: Assunçäo (2020).

1. Migração espermática entre as células da corona radiata.

2. Fixação espermática por meio da ZP (zona pelúcida).

3. Processo de fusão que ocorre entre o espermatozoide e a membrana plasmática do oócito.

\section{Retomada da Meiose e Formação do Pro núcleo}

A ativação ovocitária permite que a segunda divisão meiótica se complete. Neste processo, a célula-filha que possui baixa quantidade de citoplasma é denominada de segundo corpúsculo polar. Já a outra célula-filha é o oócito definitivo, ou seja, o zigoto (HYTTEL; SINOWATZ \& VEJLSTED, 2010). Neste contexto, o consulado de cromossomos haploides presente no zigoto é circundado por camadas do reticulo endoplasmático liso. Este contribui na formação do envelope nuclear e também na formação do pro núcleo materno (ou núcleo vesicular) (Figura 12).
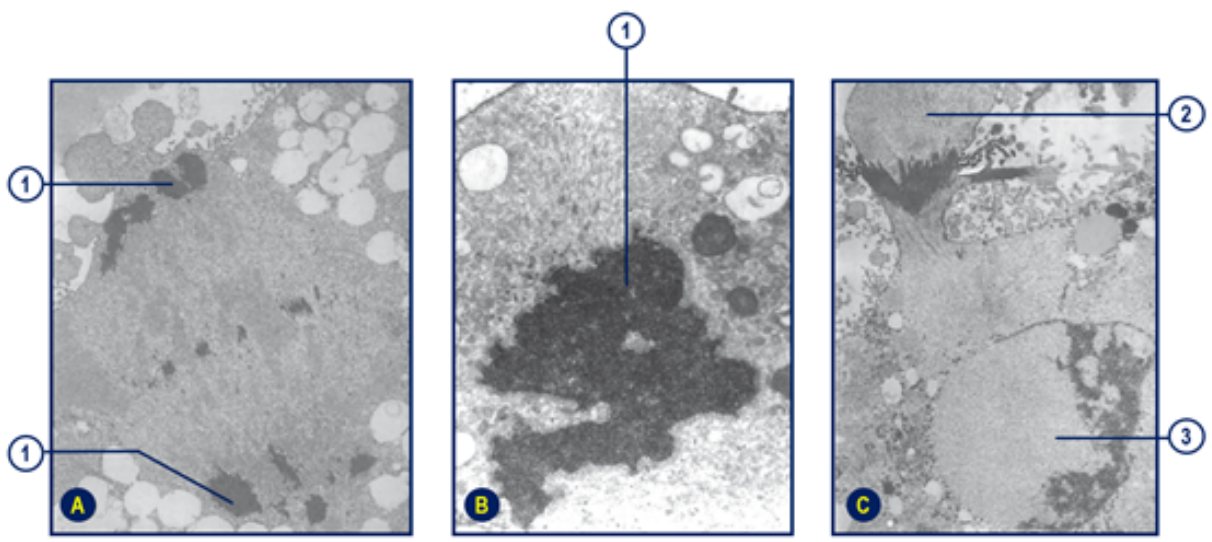

Figura 12. Processo de formação do pro núcleo na fêmea. (A) Consequência da afvação ovocitária completando a segunda divisão meiótica. (B) Oócito definitivo. (C) Pro núcleo materno formado. 1: Conjunto haploide de cromossomos; 2: Corpúsculo polar; 3: Pro núcleo feminino. Fonte: Hytel (2010).
No oócito grânulos corticais são encontrados, com isso a membrana plasmática não permite mais a penetração de outro espermatozoide, assim como a zona pelúcida modificada impede a ligação de outra desta célula com a zona pelúcida $e$ ocasionando sua penetração. Todas essas reações ocorrerem para impedir a penetração de mais de um espermatozoide no oócito. 
O núcleo do espermatozoide passa por modificações marcantes dentro do citoplasma do oócito. Uma dessas modificações é caracterizada pela descondensação. Ao descondensar, o núcleo do espermatozoide requer a redução das pontes dissulfeto (junção de dois grupos tiol). Por ocasião, o oócito da fêmea neste momento encontra-se circundado por reticulo endoplasmático liso contribuindo para um envelope nuclear e na formação do pro núcleo paterno (Figura 13). No decorrer deste processo, auxiliados pelo citoesqueleto da célula formada, ou seja, do zigoto, os pro núcleos tanto do macho quanto da fêmea se aproximam (Figuras 14,

15).
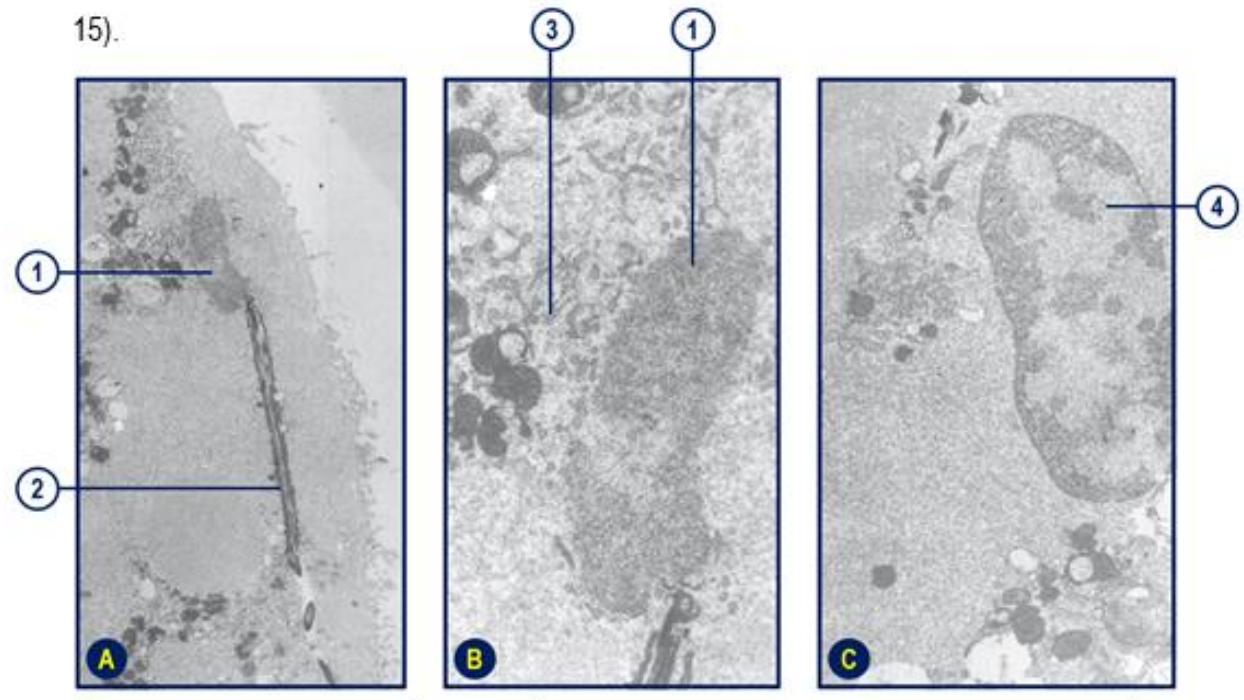

Figura 13. Processo de formação do pro núcleo no macho. (A) Espermatozoide capturado pelo ócito no processo fagocifico. (B) Núcleo espermático rodeado por camadas de reticulo endoplasmático liso. (C) Pro núcleo paterno formado. 1: Núcleo espermático em descondensação; 2: Cauda espermática em degeneração; 3: Resculo endoplasmásco; 4: Pro núcleo do macho. Fonte: Hytel (2010).

Proteinas as quais o DNA espermásco torna-se empacotado são substuidas pelas histonas do oócito. Neste processo, a cauda dos espermatozoides se destacam do mesmo e se degenera.

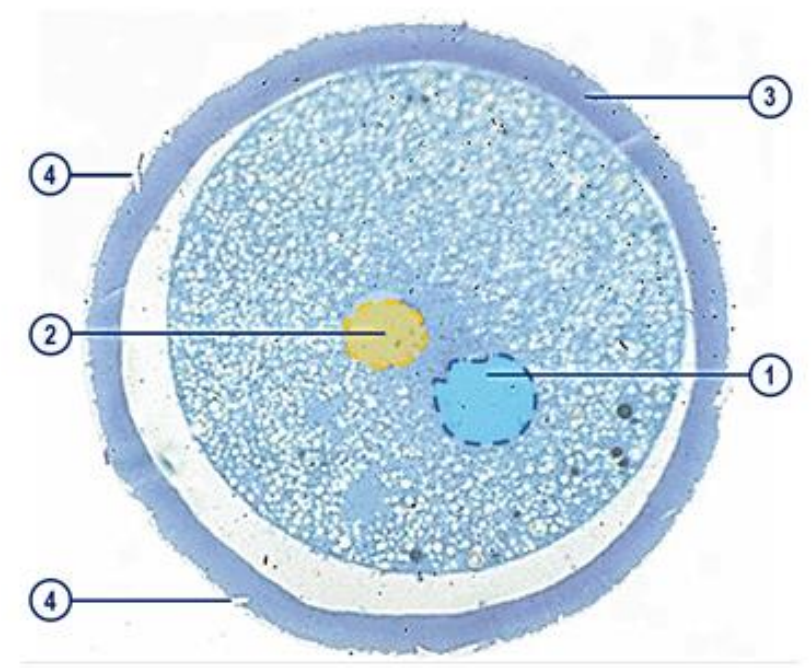

Figura 14. Pro núcleo do macho e da fêmea de um zigoto bovino em aproximação. (1) Pro núcleo paterno. (2) Pro núcleo materno. (3) Zona pelúcida (ZP). (4) Espermatozoide penetrando a ZP. Fonte: Hytel (2010) adaptado Assunção (2020). 
A aproximação dos pro núcleos do macho e da fêmea, faz com que seus envelopes nucleares se percam e faz com que o reticulo endoplasmático liso se dissolva. No processo de dissolução dos envoltórios, os genomas haploides tanto do macho quanto da fêmea são unidos no centro da célula ovo formada, o zigoto. Este evento como já mencionado neste capitulo, é denominado cariogamia. É importante ressaltar que no processo da fecundação, os pro núcleos de animais da classe Mammalia, ou seja, dos mamiferos, não sofrem fusão de fato.
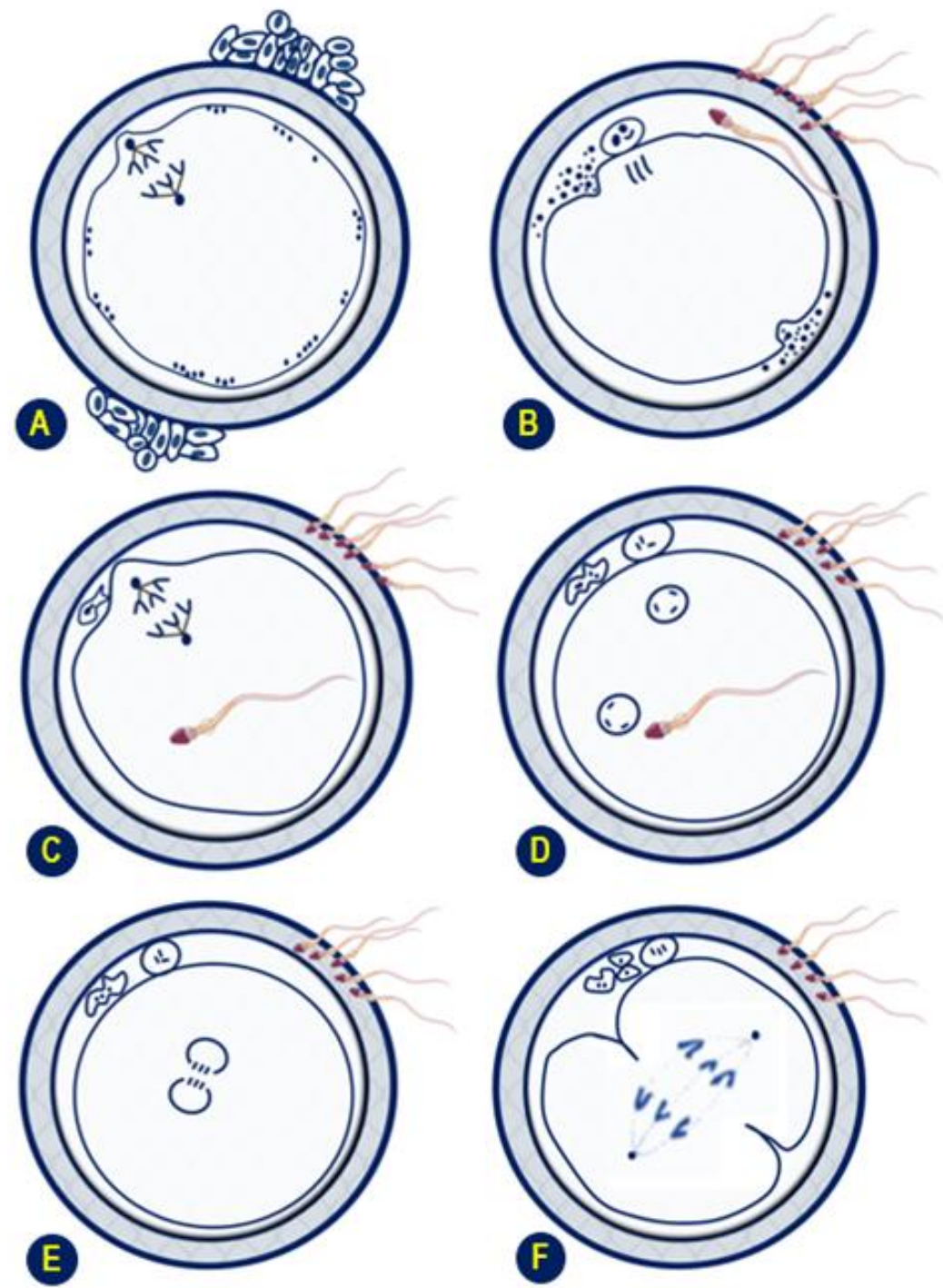

Figura 15. Representação geral da fecundação em animais da classe Mammalia. (A) Anáfase da primeira divisão meiósica no foliculo. (B) Espermatozoide ganhando o espaço perivitelinico. (C) Espermatozoide capturando pelo oócito pelo processo de fagocitose. (D) Formação dos pro núcleos do macho e da fêmea. (E) Cariogamia. (F) Primeira divisão mitótica do zigoto. Fonte: Hytel (2010) modificado Assunção (2020).

Espermatozoides em fase de maturação apresentam pouco ctoplasma e não possuem qualquer sintese proteica detectável. Por muto tempo considera-se que 0 espermatozoide contribui para um embrião em desenvolvimento pouco mais do que com os genes advindos do pai, enquanto 0 oćcito, contendo RNA's e proteinas, dirige exclusivamente para 0 desenvolvimento inicial do embrião. 
Por meio da migração dos pro núcleos, a fase $S$ do primeiro ciclo œelular pósfecundação é completada e, na dissolução dos envoltórios nucleares dos pro núcleos, a cromatina condensa-se para formar a prófase da primeira divisão mitótica.

Portanto, a clivagem que ocorre seguida a primeira divisão mitótica se completa no decorrer das 24 horas pós-ovulação. Após o periodo ovulatório se o oócito não é fecundado, o mesmo perde seu potencial de desenvolvimento (HYTTEL; SINOWATZ \& VEJLSTED, 2010)

\section{Atividades}

a) Qual a importância da fecundação no desenvolvimento embrionário?

b) Defina anfimixia e explique como se dá o mecanismo de ação do espermatozoide na fecundação.

c) Diferencie reação acrossomal de reação zonal.

d) Os eventos criticos no processo de fecundação dos mamiferos são 3, descreva-os.

e) Descreva detalhadamente o processo de ativação do desenvolvimento citoplasmático do ovo mamifero.

\section{Referências}

GILBERT, S. F. Determinação do sexo. In: Biologia do desenvolvimento. 5. ed. São Paulo: FUNPEC, 2003. p. 773-804.

MOORE, K.; PERSAUD, T. V. N. Embriologia Básica. 8ed. São Paulo: Elsevier, 2008. $462 p$.

HYTTEL, P.; SINOWATZ, F. \& VEJSTED, M. Domestic Animal Embryology. 11th ed Saunders, Elsevier, p.359. 2010. 

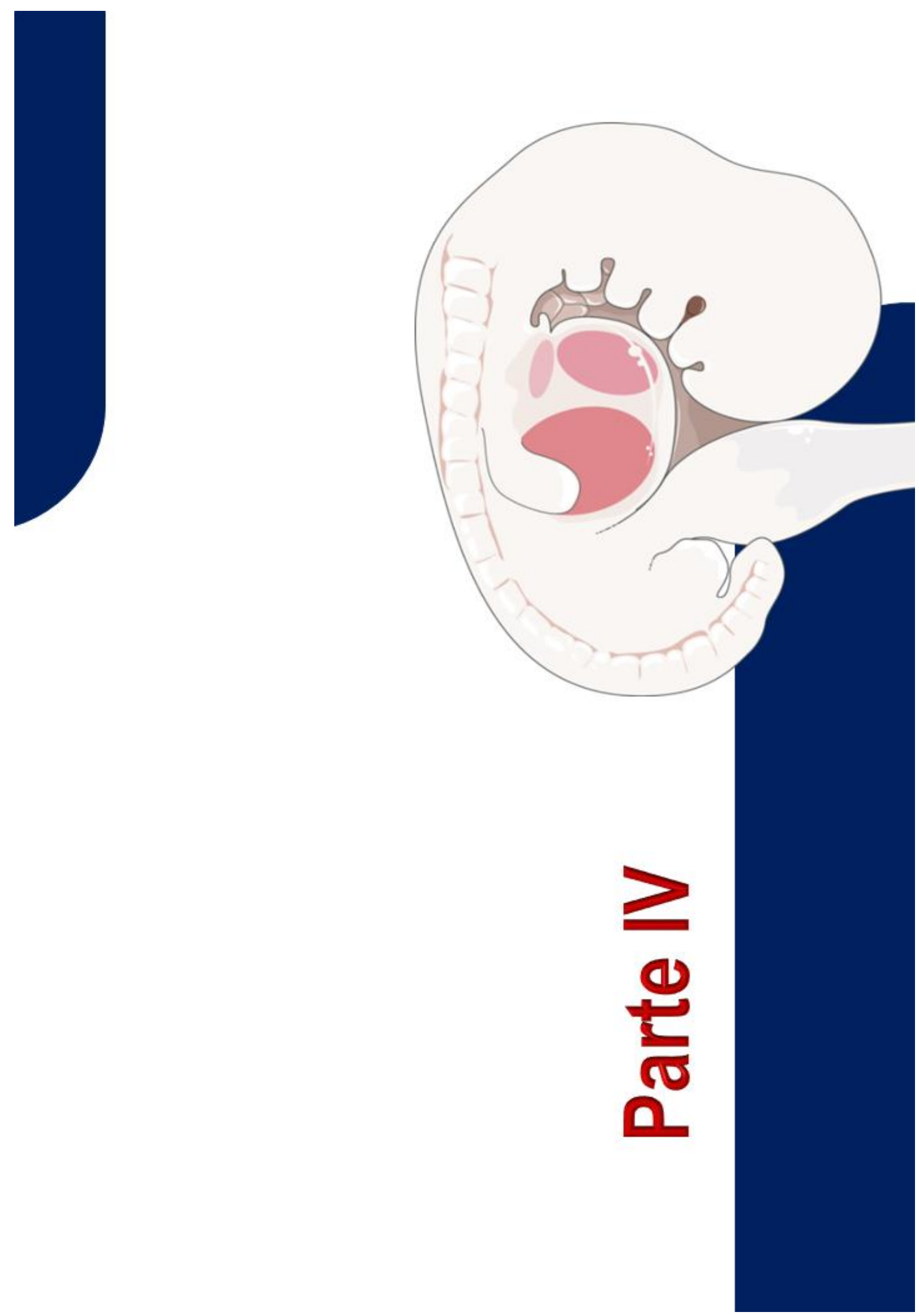


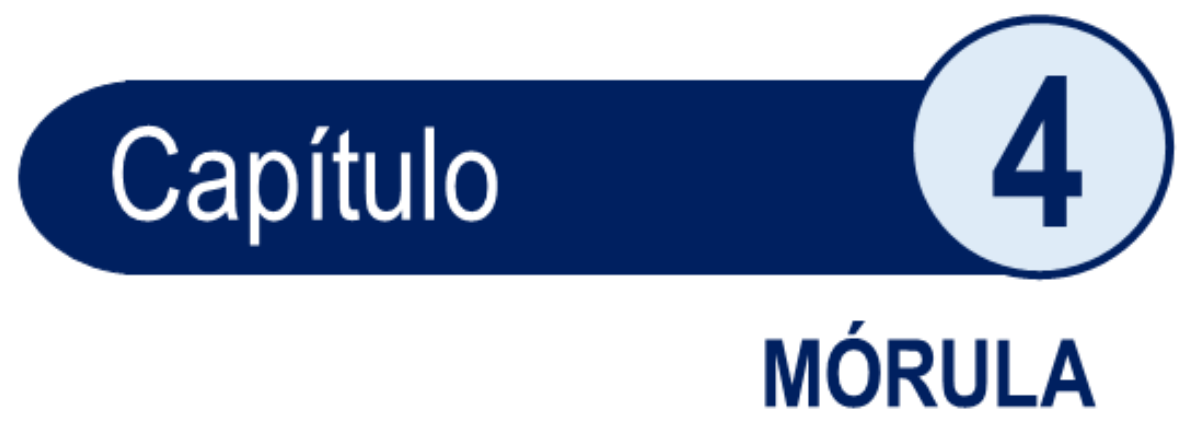

\section{Introdução e Conceitos Gerais}

O estágio de mórula se apresenta após a ocorrência das divisões œlulares. É neste momento que o embrião passa adquirir o formato de uma pequena massa de células. Etimologicamente, Mórula é uma palavra que se originou do latim que significa amora. Para tanto, compreende o primeiro estágio da embriogênese de alguns tipos

Clivagem (ou segmentação): designação para uma série de divisöes mitóticas nas quais 0 enorme volume do citoplasma do zigoto é subdivididos em pequenas células nucleadas. de zigoto (ć́lula resultante da união dos gametas do macho e da fêmea), ou seja, é o processo que sucede à fecundação.

Neste estágio do desenvolvimento, o zigoto sofre sucessivas clivagens e, $\infty \mathrm{m}$ isso, possibilita que ocorra a formação da blástula. Hyttel et. al., (2010) reportaram que a célula ovo cliva em um embrião de duas células na primeira mitose. Cada célula é denominada blastômero. Estes podem apresentar tamanhos desiguais por consequência da assincronia na clivagem. Em sua constituição, verifica-se uma cópia completa do genoma embrionário (Figuras 16 e 17).

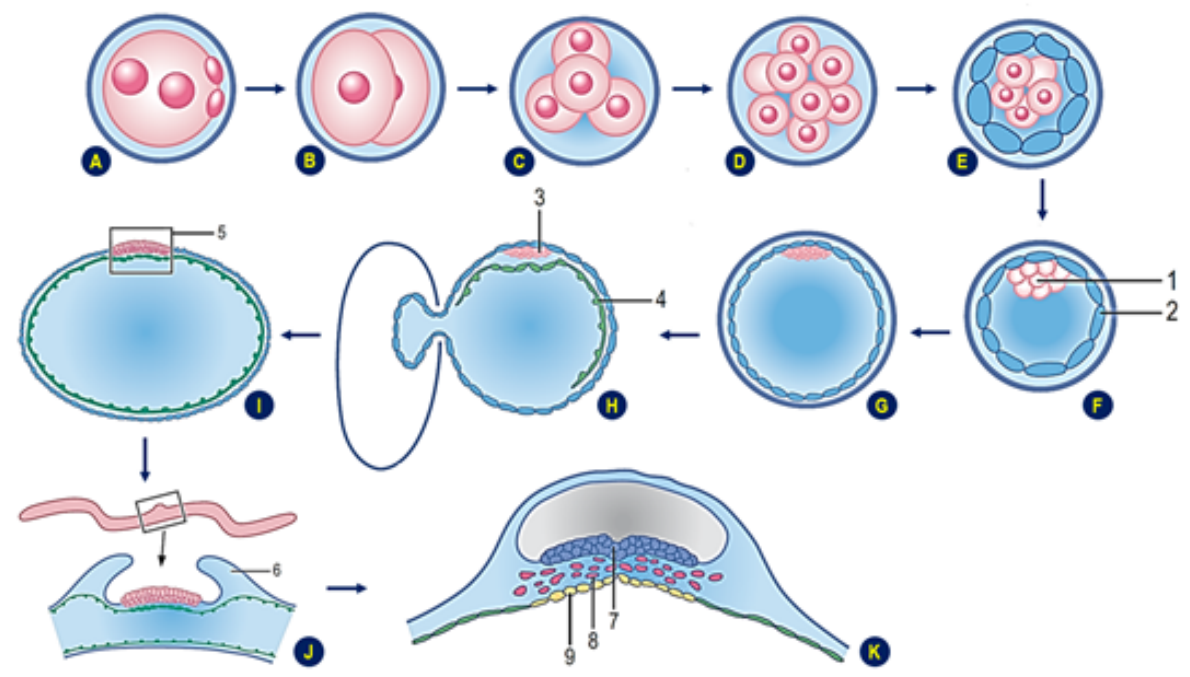

Figura 16. Esquema do desenvolvimento embrionário em fase inicial de mamiferos. (A) Zigoto. (B) Embrião de 2 células. (C) Embrião de 4 células. (D) Mórula inicial. (E) Mórula compacta. (F) Blastocisto. (G) Blastocisto expandido. (H) Blastocisto eclodindo da ZP. (I) Blastocisto ovoide com disco embrionário. (J) Blastocisto alongado. (K) Disco embrionário no processo de Gastrulação. 1 - Massa celular interna. 2 - Trofectoderma. 3 - Epiblasto. 4 - Hipoblasto. 5 - Disco embrionário. 6 - Pregas amnióticas. 7 Ectoderma. 8 - Mesoderma. 9 - Endoderma. Fonte: Hytel (2010) modificado Assunção (2020). 
Trofectoderma: termo ufilizado quando se refere a um periodo que antecede a placentação.

Trofoblasto: células compromesdas com a formação da placenta.
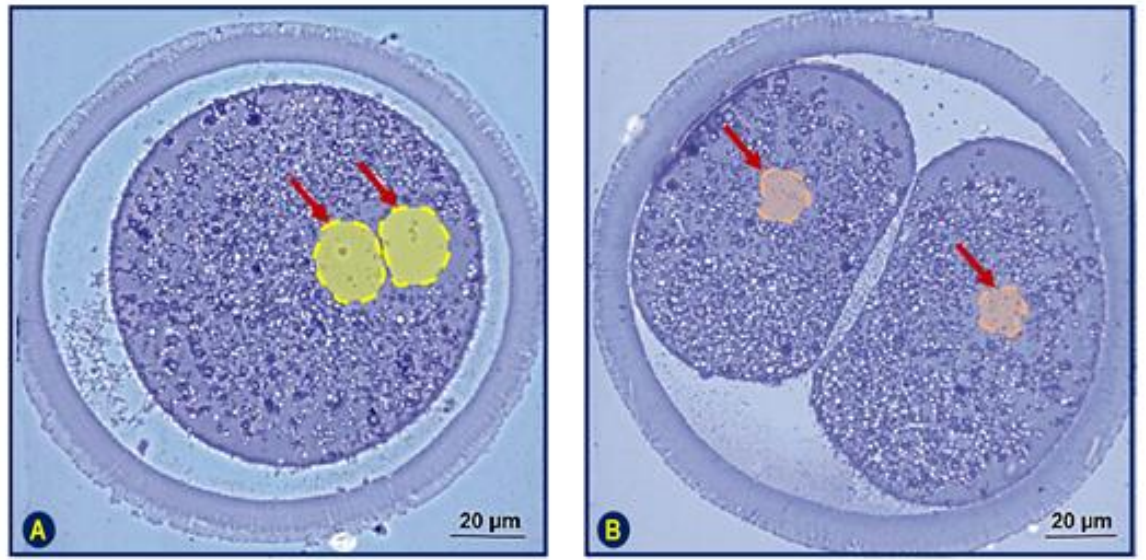

Figura 17. Cortes do desenvolvimento embrionário. (A) Zigoto da espécie bovina com presença de dois pro núcleos (setas). (B) Embrião de 2 células com presença de núcleos (setas). Fonte: Hytel (2010) adaptado Assunção (2020).

Em todas as espécies de animais já conhecidas incluindo os animais domésticos, após o processo de clivagem que é bem regulado pelas questões genéticas, a célula ovo ganha um novo potencial genético. A forma em que a clivagem ocorre está diretamente relacionada à quantidade de vitelo que há no ovo, fato que não apenas condiciona a maneira pela qual ocorre a clivagem, como pode retardá-la e até mesmo impedi-la. Vale ressaltar que os fatores citoplasmáticos são essenciais na formação do fuso mitótico.

No decorrer do processo, é notória a presença de células localizadas na face externa da mórula. Estas entram em processo de diferenciação, tornando-se em um epitélio que se adere ao embrião, conferindo ao mesmo uma superficie mais lisa, que constitui o trofectoderma (ou trofoblasto).

Segundo Hyttel et. al., (2010) este processo é denominado embriologicamente de "compactação". Sua ocorrência difere entre as espécies (Figura 18). No suino por exemplo, a compactação ocorre no estágio de oito células; Já no bovino por volta do estágio compreendido entre 16 a 32 células.

As células presentes no trofectoderma demonstram junções intercelulares especializadas, fortemente aderidas, que podem ser do tipo oclusivas ou desmossomais. Assim, um tipico epitélio com compartimentos celulares apicais e basolaterais é formado (GILBERT, 2003). 

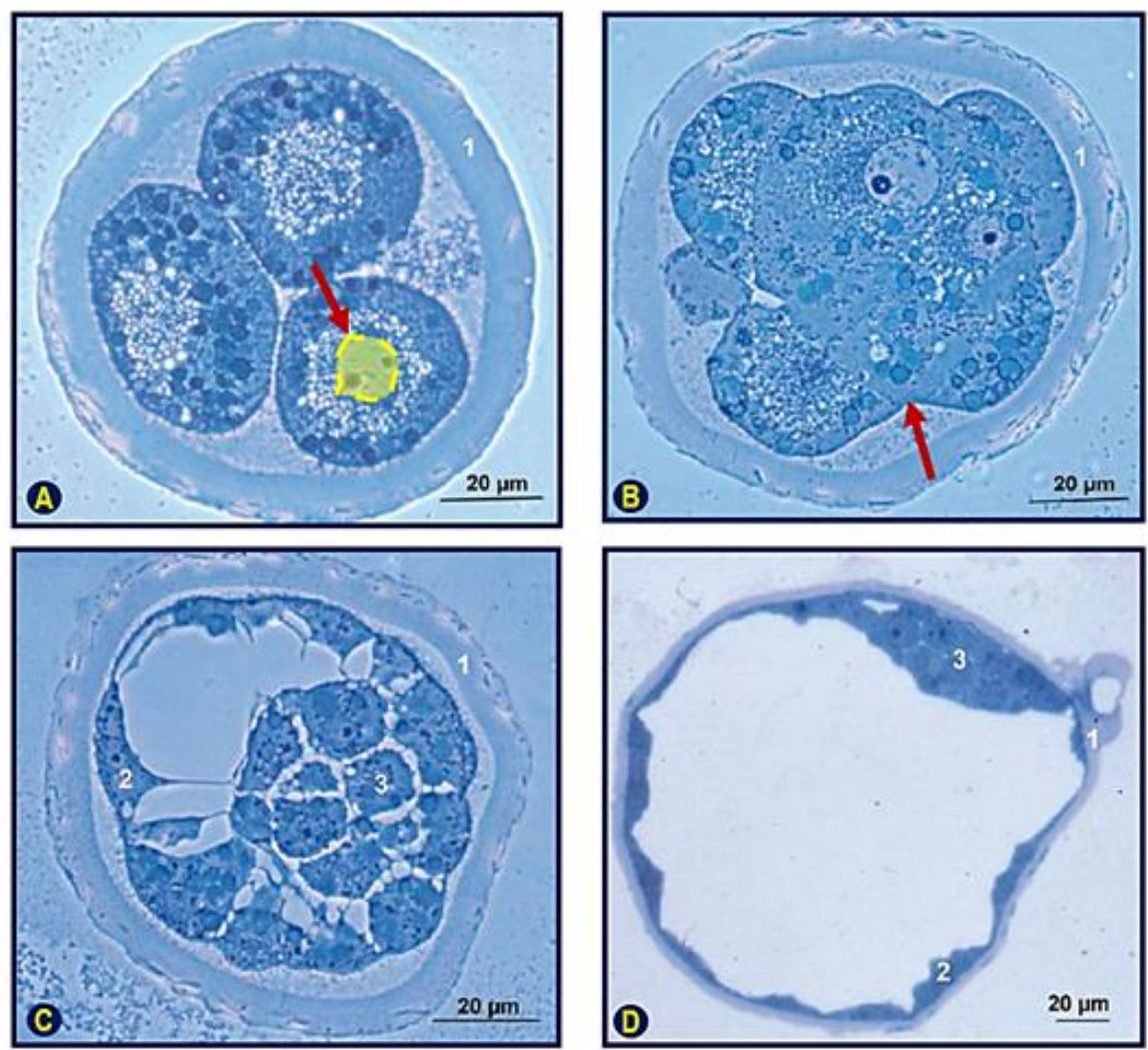

Figura 18. Cortes do desenvolvimento embrionário de suinos (Sus scrofa). (A) Embriöes de 4 células apresentando três blastômeros e um núcleo (seta). (B) Mórula em processo de compactação com estreita ligação entre células externas (seta). (C) Blastocisto. (D) Blastocisto expandido. 1-Zona pelúcida (ZP). 2 - Trofectoderma. 3 - Massa celular interna (MCl). Fonte: Hytel (2010) adaptado Assunção (2020).

\section{Diferentes tipos de Clivagem}

O processo de clivagem que ocorre ao longo do desenvolvimento embrionário apresenta-se em diferentes tipos. O vitelo é extremamente importante para sua ocorrência sendo um dos fatores que influenciam o padrão da clivagem em uma dada espécie. Estes padrões podem também ser herdados de divisões celulares, e, restrições podem ser observadas quando ovos apresentam baixa quantidade de vitelo, como, por exemplo, em ovos oligolécitos (GILBERT, 2003). Na página seguinte estão definidas as modalidades acerca da diferenciação e suas caracteristicas.

Clivagem meroblástica: Ovos que apresentam grande quantidade de vitelo e que podem ser classificados como telolécito e/ou centrolécito. Nestes são observadas interferência sobre os sulcos de clivagem. A grande concentração de vitelo quando 
constatado no polo vegetativo chega a impedir o sucesso da clivagem tornando-a a parte vitelinica pouco segmentada. A clivagem meroblástica podem apresentar duas modalidades, a saber: clivagem meroblástica discoidal ou superficial.

A clivagem meroblástica é observada no desenvolvimento de galinha (Gallus gallus domesticus) um exemplo de réptil-ave, bem como nos répteis não-aves. $\mathrm{O}$ ovo é do tipo telolécito. O processo de clivagem inicia-se no oviduto, antes dos ovos serem excretados pela fêmea para o ninho. O processo de segmentação nestas espécies atinge apenas a cicatricula que contém aproximadamente $3 \mathrm{~mm}$ de diâmetro. $\mathrm{O}$ polo vegetativo não entra em divisão. Uma massa celular é formada $e$ adquire formato de um disco denominado como disco germinativo (ou blastoderma). $\mathrm{O}$ número de células é variável (32 a 64 blastômeros), e, este caracteriza a fase de mórula. Para tanto, o limite que se apresenta entre o disco germinativo e o vitelo é praticamente impossivel de instituir.

Na primeira clivagem, o sulc minora à medida que se aproxima do limite citoplasma-vitelo, enquanto na segunda o sulco é perpendicular à primeira. Esses dois planos são ditos meridionais (Figura 19 - B), muito embora chegam apenas numa pequena porção do ovo. A terceira segmentação ocorre segundo dois planos meridionais, paralelos ao primeiro e perpendiculares ao segundo. Esses dois terceiros planos não se dispõem de sincronia no seu desenvolvimento. Já a quarta clivagem apresenta sincronia e planos meridionais. No entanto, o quarto plano de segmentação ocorre de tal modo que isolam oito blastômeros no centro do disco germinativo e oito blastômeros periféricos. O limite com o vitelo ainda não é distinto. Os limites dos blastômeros só existem na superficie, não tendo, nem nos blastômeros centrais, limites em profundidade.

O processo de segmentação prossegue, e é notório no decorrer do desenvolvimento verificar que as células centrais se multiplicam rapidamente. Ao redor delas, encontram-se os blastômeros que têm apenas limites radiais, e que não apresentam limites periféricos. Quando o disco germinativo chega ao estágio de 32 a 64 células, é possivel observar clivagens apenas citoplasmáticas, levando ao estabelecimento de um limite inferior do disco germinativo, pois esse separa os blastômeros do vitelo, formando inicialmente uma fenda virtual denominada de cavidade subgerminal. Essa separação ocorre do centro do disco germinativo embrionário para a periferia. 
A partir de 64 blastômeros, o disco germinativo elimina um liquido que estendese em direção ao vitelo, e, uma cavidade é formada, cujo teto é o próprio disco germinativo. O seu assoalho é constituido por uma membrana de células sem limites definidos, o periblasto. O periblasto envolve a massa vitelinica e a cavidade passa a ser considerada como blastocele primaria (cavidade subgerminal ou cavidade de segmentação). Vale salientar que as células da periferia continuam aderidas ao vitelo.

$\mathrm{O}$ aumento do número de células continua especialmente na porção central onde as células se tornam cada vez menores, quando comparadas aquelas situadas nas margens periféricas. Logo é possivel observar que a região œentral passa a ter várias camadas de células situadas acima da cavidade subgerminal. Mais tarde é possivel observar na região periférica, a ocorrência de segmentações horizontais as quais separam as células em camadas bem delimitadas (superiores) e camadas sem limites com o vitelo (inferiores). Estas últimas formam um sincicio marginal que contorna o disco germinativo

Em vista superior, o disco germinativo, apresenta áreas definidas que são denominadas central e periférica. A área central é embriologicamente definida como área pelúcida e a periférica como área opaca. A área pelúcida corresponde aos blastômeros centrais os quais, por não estarem aderidos ao vitelo, transmitem a aparência transluzente ao embrião. A área opaca corresponde aos blastômeros periféricos, os quais, estão interligados ao vitelo, demonstrando um aspecto denso.

Para Houillon (1972) as camadas periféricas que compõem a área opaca demonstram diferentes divisões, a saber: blastômeros tipicamente periféricos, as quais dividem ativamente as células sobre o vitelo, sendo que as mesmas em estado de divisão incorporam-se sobre o vitelo passando a constituir a zona de cobertura; a zona de junção na qual a camada celular profunda não demonstra limite $œ m$ o vitelo, constituindo o sincício vitelino; e a zona interna na qual algumas células provenientes da zona de junção adquiriram limites celulares, e localizam-se entre as áreas opaca e pelúcida, demonstrando citoplasmas ricos em vitelo. São células grandes e formam a chamada parede germinativa.

Clivagem holoblástica: neste estágio, a célula ovo (ou zigoto) divide-se completamente de maneira extremamente regular. O plano da primeira divisão contem um sulco que se estende em linha reta, desde o polo animal até o vegetal, dispondo-se 
paralelamente ao eixo principal do zigoto. Já o plano da segunda divisão é mais perpendicular em relação ao primeiro. Assim, ambos dão origem a quatro blastômeros, as quais $\infty \mathrm{m}$ o plano da terceira divisão são seccionados equatorialmente, resultando em oito blastômeros, dispostos em duas camadas, ou seja, quatro no polo animal e quatro no vegetal.

A clivagem holoblástica pode ser subdividida em diferentes tipos: radial, espiral, bilateral e rotacional. A clivagem holoblástica radial caracteriza-se pelo plano meridiano sob o eixo de polaridade do zigoto (animal-vegetal) onde os blastômeros formados apresentando tamanhos semelhantes; esse subtipo de clivagem pode ser observado em equinodermos e no Anfioxo, bem como em alguns peixes ganoides, rãs e salamandras (Figura 19).

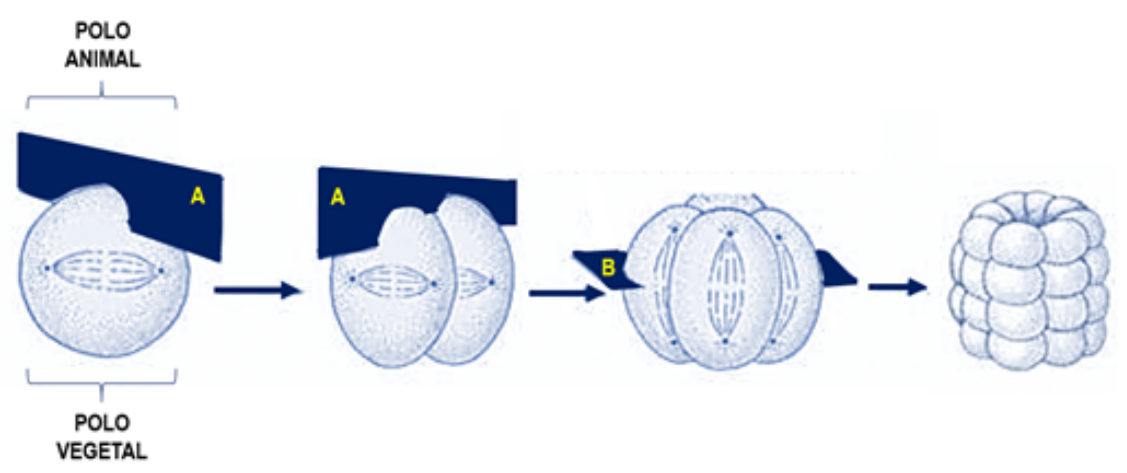

Figura 19. Representação didáica da clivagem holoblásica do ipo radial em Equinodermos. (A) Plano de clivagem meridional. (B) Plano de clivagem equatorial. Fonte: Vanderley \& Santana (2015) adaptado Assunção (2020).

Blastômero: denominação para células embrionárias em estado de segmentação (ou clivagem).

Apesar de algumas espécies de animais apresentarem clivagem holoblásica do tipo radial, a mesma vai mostrar algumas caracterisicas sui generis, mesmo sendo determinada por fatores citoplasmáticos ou até mesmo pela interferência do vitelo presente na célula ovo ao longo do desenvolvimento.
A clivagem holoblástica espiral difere da radial pois os planos deixam de ser orientados paralelamente, e passam a ter orientações obliquas em relação ao eixo principal do zigoto. Com isso, formações dispostas em espiral dos blastômeros-filhos são constatadas. As células embrionárias segmentadas (blastômeros) presentes no polo animal não ficam sobrepostas ao polo vegetal, ou seja, apresentam-se de forma intercalada (Figura 20). Este tipo de segmentação é carateristico de animais, tais como anelideos, platelmintos tubulares, nemertineos e grande parte dos moluscos com exceção dos cefalópodes. 

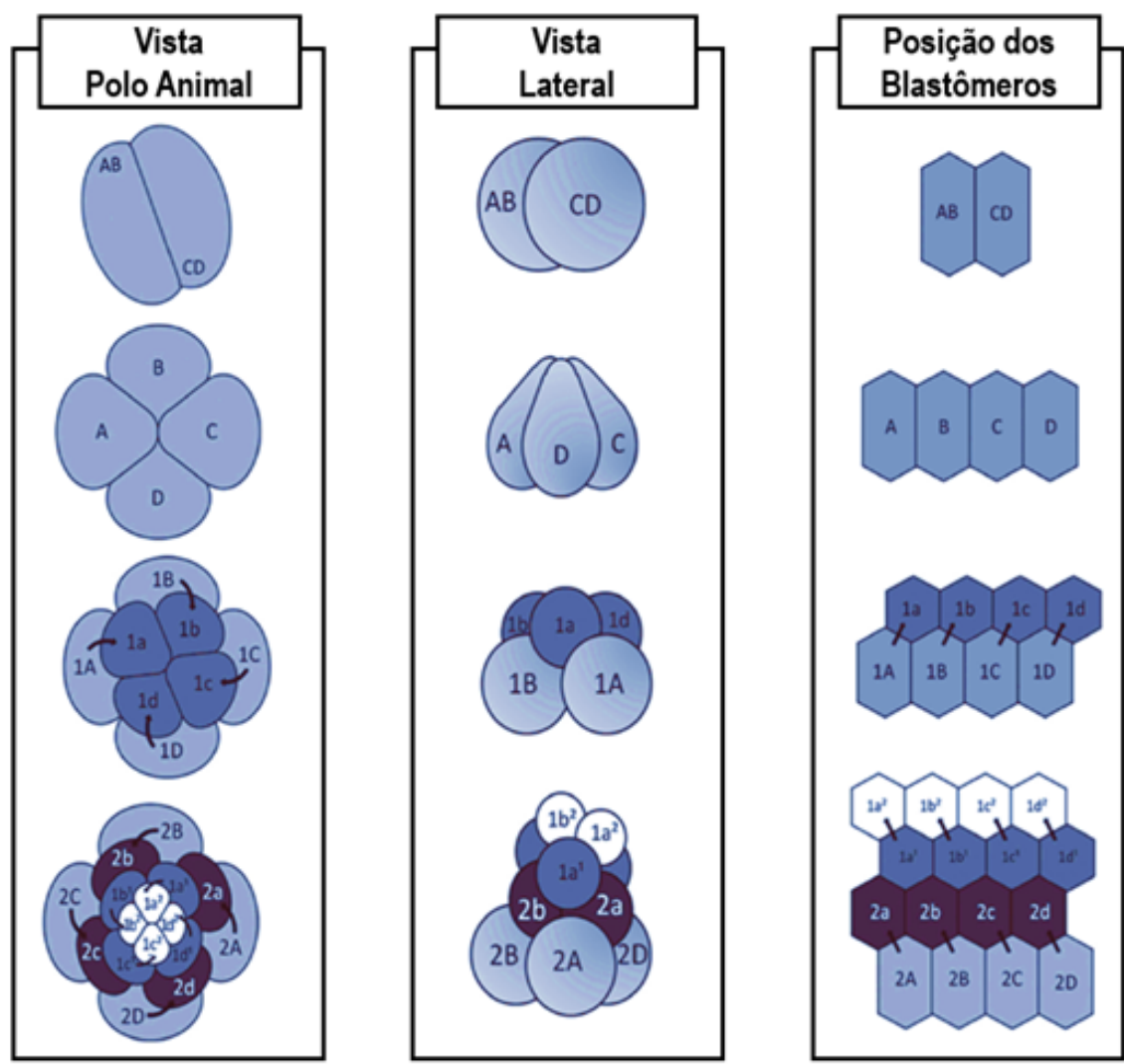

Figura 20. Representação da Segmentação meroblástica do fipo espiral. Em observação, note a inversão da inclinação dos fusos acromáticos indicados pelas setas, estes apresentam-se dextrotrópicos no estágio de oito células e levotrópicos para 0 de 16 células. Fonte: Vanderley \& Santana (2015) adaptado Assunção (2020).

\section{A clivagem holoblástica bilateral é um tipo de segmentação presente em} animais tunicados (ascidias) e nematódeos. Assim, o primeiro plano de clivagem que ocorre nestes animais, corresponde ao plano de simetria bilateral do embrião em desenvolvimento, e define os antimeros tanto esquerdo quanto direito. Neste contexto, o embrião em desenvolvimento a partir deste estágio apresenta-se sempre sob a forma de dois antimeros simétricos, onde cada blastômero de um lado corresponde a um blastômero simétrico do lado oposto.

A clivagem holoblástica rotacional é caracteristica de zigotos presentes no desenvolvimento de animais placentários da Classe Mammalia (Mamiferos). Esse tipo de segmentação é bem diferente dos padrões celulares embrionários já mencionados anteriormente neste capitulo. Uma das caracteristicas que este tipo de clivagem difere das demais, é o fato do seu processo ser um dos mais lentos dentro do Reino Animal.

Por que pontuar 0 "blastômero simétrico"? Porque uma das caracterisicas deste, è a ocorrência da segunda divisão, apesar de ser meridional (como na clivagem radial), não passa pelo centro do zigoto. Deste modo, dá-se origem em cada lado um blastômero maior na porção anterior e a um menor mais posteriormente. 
No periodo de crescimento ovocitário nos foliculos que ocorre durante a fase inicial do embrião em animais domésficos, transcritos e proteinas são acumuladas no ócito. Com 0 avançar dos estágios do desenvolvimento embrionário, ambos os componentes são gradualmente degradados e uflizados. Paralelamente, 0 genoma embrionário passa por afvaçōes menores $e$ posteriormente por afvação principal. A ccorrência deste processo pode ser observada no estágio de quatro células no desenvolvimento de suinos (Sus scrofa) e no estágio de oito células em bovinos (Bos taurus). Fonte: HYTTEL; SINOWATZ \& VEJLSTED, 2010.
Outro ponto não menos importante a ser destacado neste processo de segmentação é a orientação singular dos blastômeros dos mamiferos em relação ao outro (Figura 21).

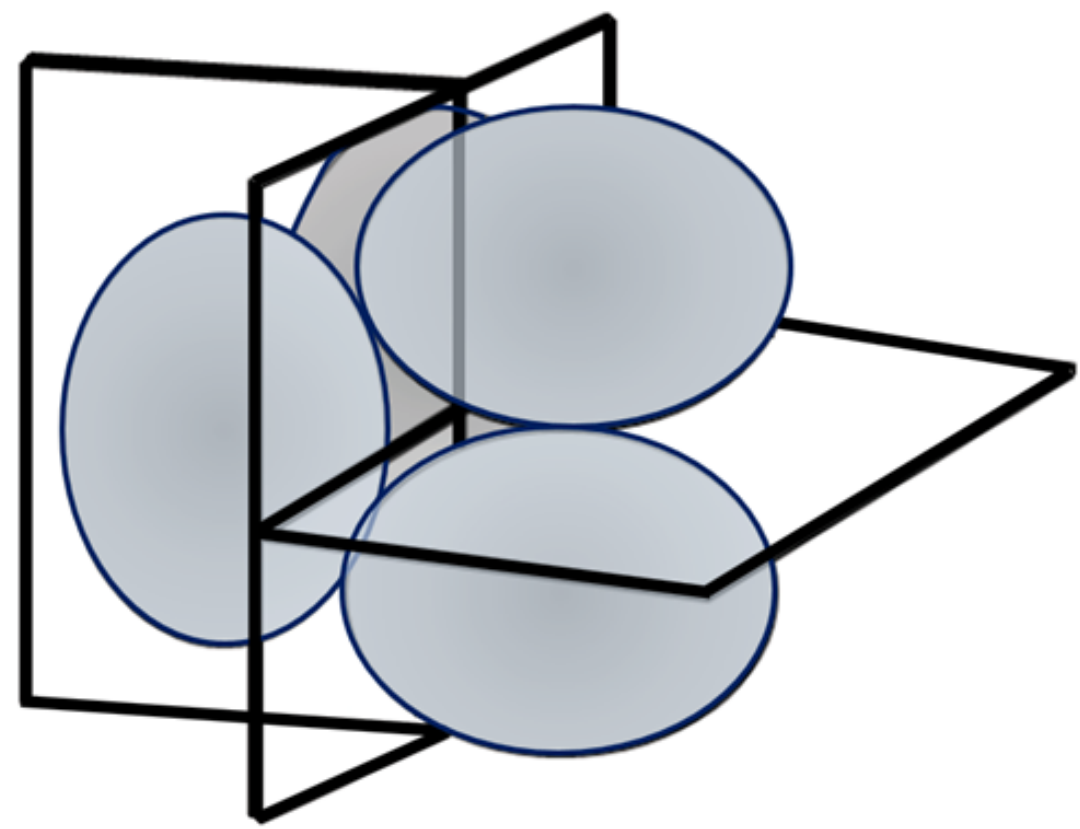

Figura 21. Esquema do processo de Clivagem holoblástica do tipo rotacional presente no desenvolvimento embrionário de mamiferos. Fonte: Assunção (2020).

Isto posto, uma das particularidades que mais chama atenção no processo de segmentação dos mamiferos, é o fenômeno da compactação dos blastômeros que se dá após a fase de oito células. É a partir deste momento que os respectivos blastômeros tornam-se amainados e consequentemente se amontoam. A mudança na conformação estrutural dos blastômeros, maximiza o contato deles entre si por meio de junções intimas que se formam nas células superficiais (VANDERLEY \& SANTANA, 2015).

A compactação da mórula e os blastômeros internos formam junções com espaços $(G A P)$, os quais permitem que pequenas moléculas e ions transitem entre eles. Portanto, após a compactação as células se dividem dando origem ao embrião de 16 células. 


\section{Atividades}

a) Quais os tipos de segmentações que ocorrem ao longo do desenvolvimento embrionário?

b) Relacione os tipos de segmentações (ou clivagem) com o tipo de ovo e cite exemplos de animais que a possuem.

c) Cite e defina as características de mórula e blastocisto.

d) Estudantes envolvidos em um projeto precisam fazer a coleta de células-tronco embrionárias, porém os alunos relataram dificuldades em fazer tal intervenção. Qual seria o estágio embrionário ideal para coletá-las e o local de onde as tiraria? Justifique sua resposta.

e) É correto afirmar que uma das particularidades que mais chama atenção no processo de segmentação dos mamiferos é a não ocorrência do fenômeno de compactação dos blastômeros que se dá após a fase de oito células? Se sim, justifique sua resposta.

\section{Referências}

GILBERT, S. F. Determinação do sexo. In: Biologia do desenvolvimento. 5. ed. São Paulo: FUNPEC, 2003. p. 773-804.

HOUILLON, C. Embriologia. São Paulo: Edgard Blücher, 1972. 160 p.

HYTTEL, P.; SINOWATZ, F. \& VEJSTED, M. Domestic Animal Embryology. 11th ed. Saunders, Elsevier, p.359. 2010.

VANDERLEY, C. S. B. S. \& SANTANA, I. C. H. Histologia e embriologia animal comparada. 2. ed. - Fortaleza: EdUECE, 2015. 

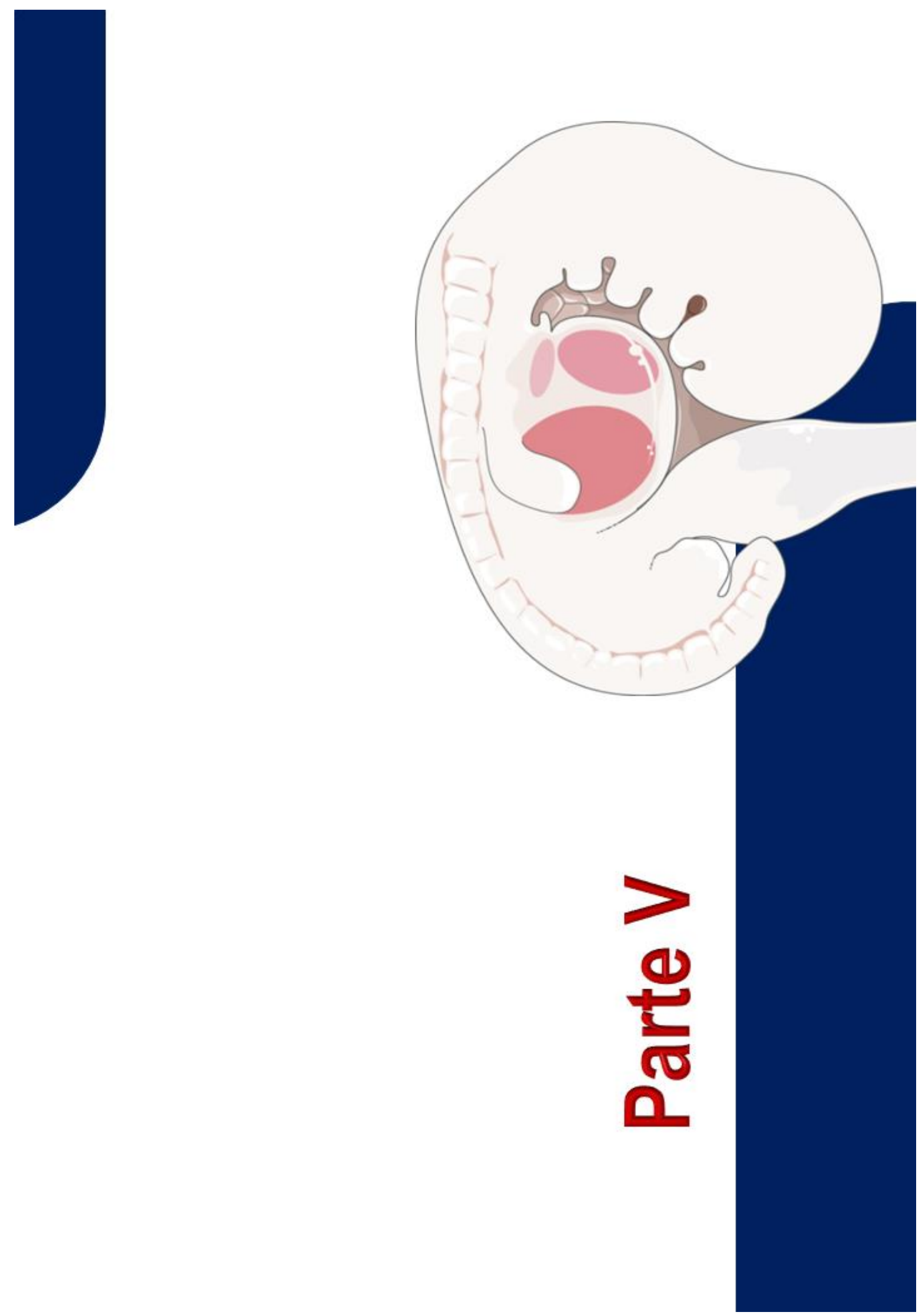


\section{Capítulo}

\section{BLASTULAÇÃO}

\section{Introdução e Conceitos Gerais}

A fase de compactação da mórula, ocorre em grande parte do desenvolvimento embrionário dos animais domésticos, e, é fundamental para compreender o presente capitulo no qual será abordado o processo de formação de uma cavidade preenchida por liquido no centro do embrião, a blastocele.

O que vem a ser blastulação? Blastulação é o processo de modificações da mórula em blástula, que ocorre mediante segmentações (ou clivagens), na qual as mudanças na disposição das células são denominadas de blastômeros. Os blastômeros sofrem um aumento numérico quantitativo bem œmo, uma diminuição dos seus volumes. Todo esse processo ocorre geralmente quando o embrião atinge e ganha o lúmen uterino no decorrer da primeira semana de desenvolvimento. Deste modo, o processo é caracterizado pela transformação do embrião em blastocisto (Figura 22).

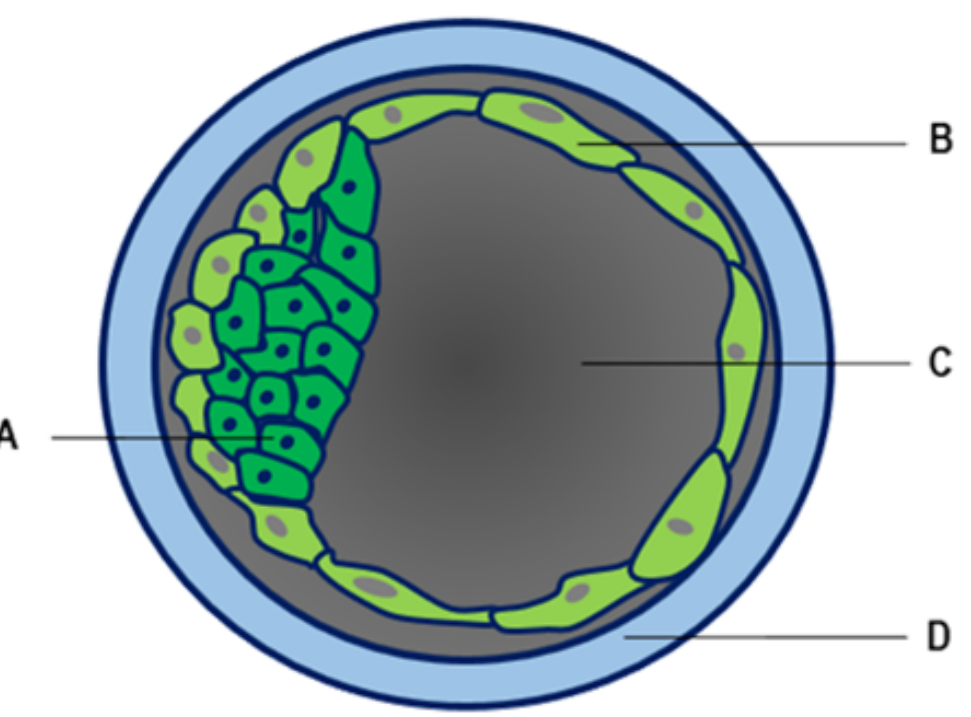

Figura 22. Representação de um blastocisto envolvido no desenvolvimento do animal. (A) Embrioblasto. (B) Trofoblasto. (C) Blastocele. (D) Zona Pelúcida (ZP). Fonte: Assunção (2020). 
0 líquido que preenche a blastocele, vem de onde? As células da mórula produz substâncias proteicas que se concentram entre as células. Assim, estas substâncias tendem a se acumular em uma só região e da origem a formação da blastocele. 0 acúmulo proteico faz com que a cavidade sofra uma hiperosmolaridade, tendendo ao equilibrio. Com isso, por osmose, ocasiona a entrada de água advinda do meio externo.

A conformidade entre células da massa celular interna $(\mathrm{MCl})$ e trofectoderma é de cerca de 1:3.

Trofectoderma polar: porção do trofectoderma que recobre a $\mathrm{MCl}$.
A blastulação segundo Hyttel; Sinowatz \& Vejlsted (2010) é provocada principalmente pelo controle do trofectoderma sobre o transporte de fluidos. A mórula contendo 16 células produz fluidos e estes promovem o deslocamento dos blastômeros para a periferia, formando de fato a blastocele comentada na pagina anterior.

$\mathrm{Na}$ blastocele, células permanecem no seu interior, e são definidas como trofoblasto (células superficiais); ainda neste estágio, é possivel observar a existência de duas populações celulares, as internas e as externas. Grande parte das células externas originam o trofectoderma, e as internas o embrião contendo o saco vitelinico, alantoide e âmnio (Figura 23). Ao final, os blastômeros internos se posicionam em um dos polos do embrião, e formam a massa celular interna $(\mathrm{MCl})$, advindas das células internas do embrião de 16 células. Analisando no conjunto, as células da $\mathrm{MCl}$, dão origem ao embrião propriamente dito, enquanto que as células do trofectoderma dão origem a parte embrionária da placenta. Blastocisto é definido a partir do conjunto de células do trofoblasto mais $\mathrm{MCl}$, caracteristica própria da segmentação presente no desenvolvimento de mamiferos.

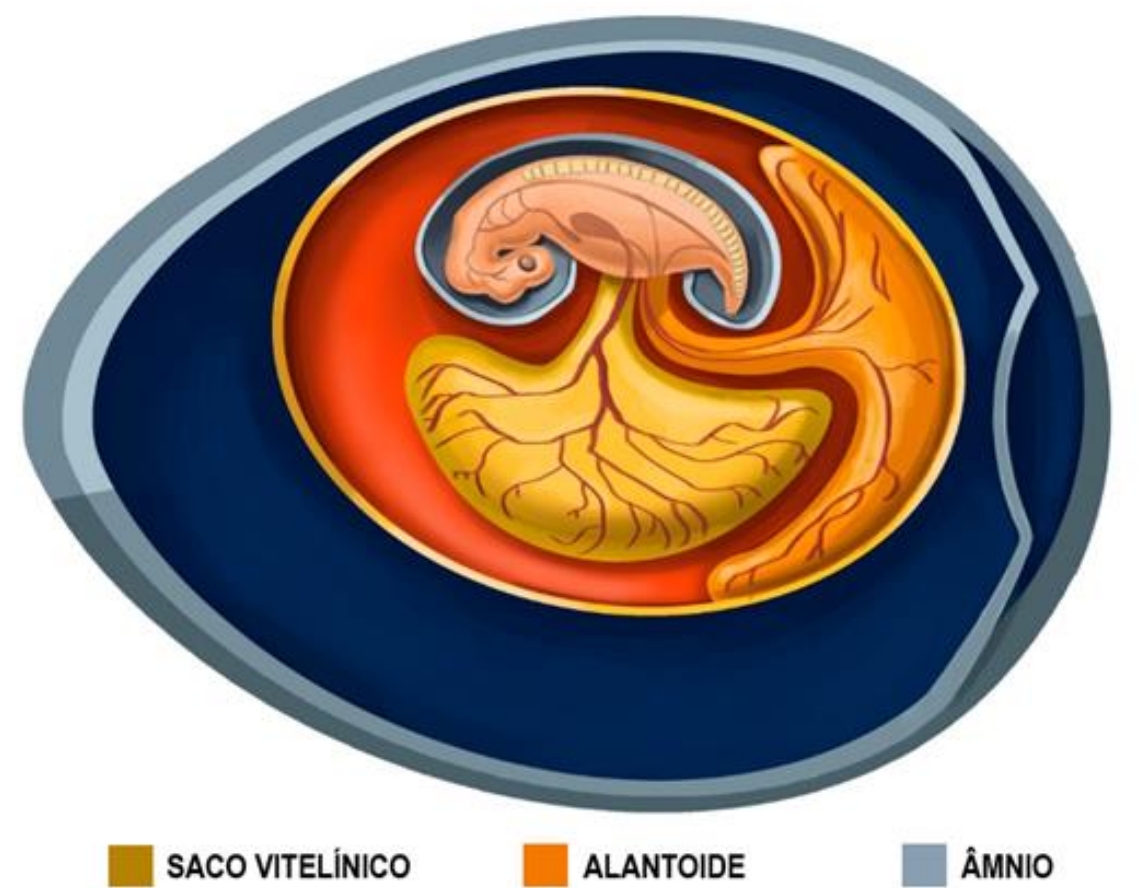

Figura 23. Esquema do desenvolvimento embrionário de Galinha (Gallus gallus domesticus). Nota-se as estruturas (Saco vitelinico, alantoide e âmnio) demarcadas pelas cores referenciadas com legendas na figura. Fonte: Assunção (2020). 
O aparecimento dessa cavidade, no interior da mórula, marca, de modo geral, a fase de blástula, que é bem conhecida em se tratando dos oligolécitos (mamiferos) e dos heterolécitos (anfibios), porém é discutida no caso dos telolécitos (répteis aves). Neste contexto, a porção volumétrica do ovo pouco se modifica ao longo do desenvolvimento de mamiferos e anfibios, o que ocorre na verdade é o aumento gradual de células em relação núcleo-citoplasma.

No interior da cavidade do blastocisto, uma pressão osmótica faz com que o embrião entre em expansão de forma gradual, e com a sua expansão a zona pelúcida (ZP), se fresta (Figura 24). Com a ruptura da ZP, o embrião se esquipa pela abertura.

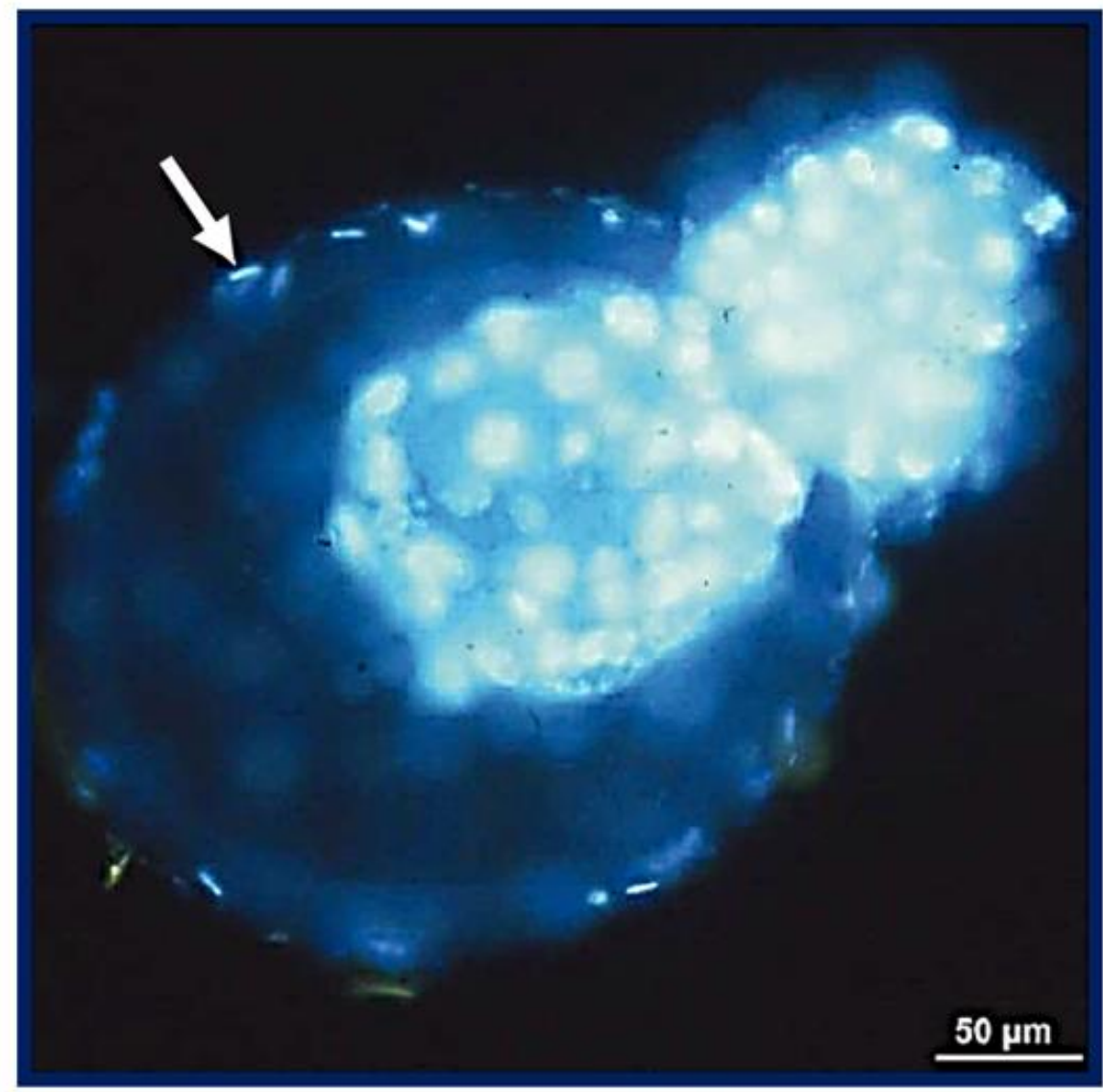

Figura 24. Blastocisto em processo de eclosão em suino (Sus scrofa). Por meio da seta é possive observar os núcleos marcados com corante fluorescente do ipo Hoechst 33342 e espermatozoides supranumerários são visualizados em adesão a ZP. Fonte: Hytel et. al., (2010).

Em algumas espécies de animais domésticos, o processo de ruptura da ZP é comumente conhecido como eclosão, que se dá pelo auxilio de enzimas proteoliticas excretadas pelo endométrio sob ação de glicoproteinas que constituem a ZP. 
Nos equinos (Equus caballus), uma cápsula "compensatória" fundamental na manutenção da prenhez é formada entre o trofectoderma e a ZP antes do processo de ruptura. A prenhez nesta espécie animal, segundo Hyttel et al., (2010) ocorre precocemente.

Mais tarde, células originadas da massa celular interna são subdivididas em hipoblasto e epiblasto. As células do hipoblasto (com caracteristica epitelial) ao longo do desenvolvimento, são voltadas para a blastocele e forma uma camada achatada, $\mathrm{e}$ as do epiblasto são remanescentes e formam uma camada multicelular com pequenas cavidades intercelulares (Figura 25).
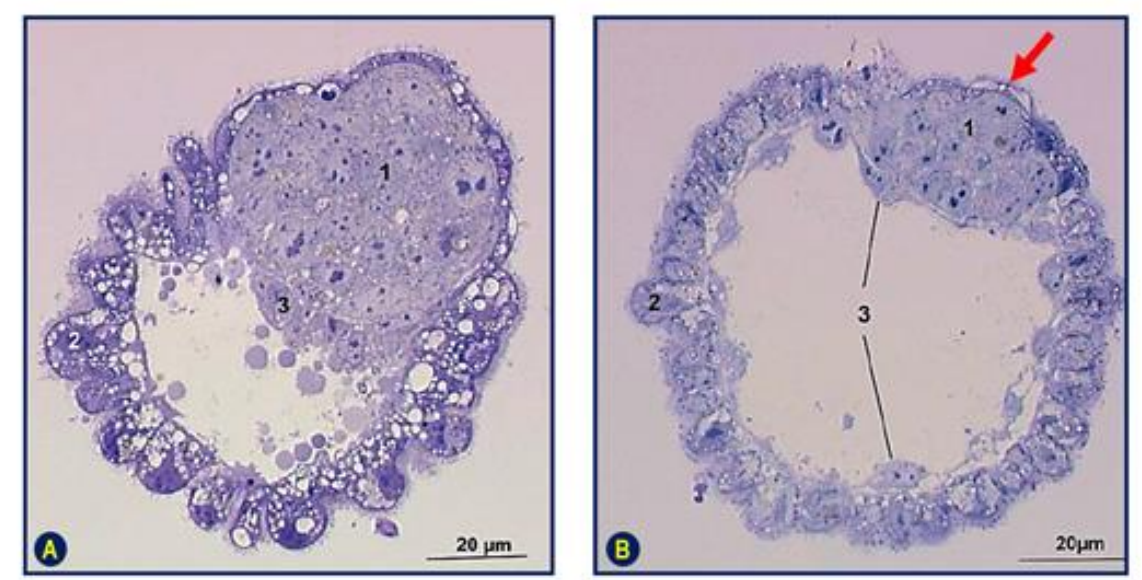

Figura 25. Blastocistos bovinos (Bos taurus). (A) 10 dias do desenvolvimento embrionário. (B) 12 dias do desenvolvimento embrionário. 1 - Epiblasto. 2 - Trofectoderma. 3 - Hipoblasto. $\mathrm{Na}$ figura (B) por meio da indicação da seta, é possivel observar o trofectoderma polar que recobre o epiblasto (camada de Reuber). Fonte: Hytel et. al., (2010).

O embrião propriamente dito se forma a partir do epiblasto, enquanto o hipoblasto forma o epitélio interno do saco vitelinico, o qual dependendo da espécie, pode estar comumente relacionado com a placentação. Nas espécies domésticas, o epiblasto é encontrado no ambiente uterino após a desintegração do trofectoderma (HYTTEL; SINOWATZ \& VEJLSTED, 2010).

$\mathrm{Na}$ figura 25 - B, é possivel observar por indicação da seta, o epiblasto; junto ao hipoblasto torna-se conhecido como disco embrionário onde no decorrer da sua formação, o blastocisto ainda encontra-se em expansão. Com a formação completa do disco embrionário, o trofectoderma mais o hipoblasto é remodelado dando formato ovoide ao embrião (Figura 26). 


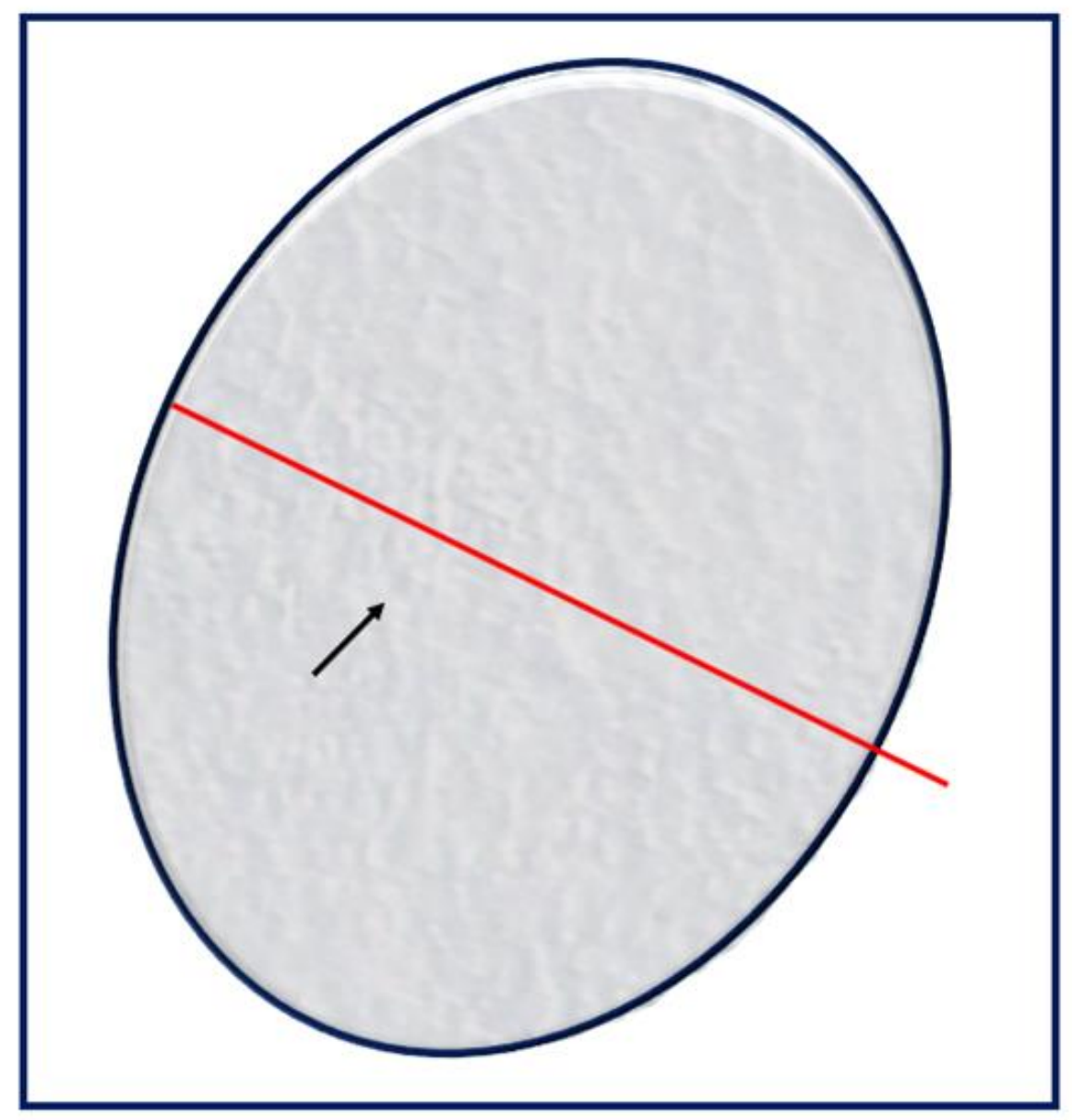

Figura 26. Representação didática de um disco embrionário, por vez, a visualização do disco embrionário de fato, é dificultada. Com o corte no disco (linha vermelha), na histologia, é possivel observar consituintes não visiveis nesta representação, como: epiblasto, hipoblasto, trofectoderma, etc. Fonte: Hytel et. al., (2010) modificado Assunção (2020).

Nas espécies domésticas, o volume embrionário não sofre aumento no decorrer da segmentação, ou seja, não há aumento com relação volume-citoplasma. 0 grande volume citoplasmático do zigoto é dividido cada vez mais em células menores. Praticamente, só quem se replica é o conteúdo nuclear, para depois ser dividido. A célula ovo (ou zigoto), é segmentado ao meio na sua primeira divisão; em seguida, em quartos, em oitavos, e assim por sucessivamente.

A divisão que ocorre a nivel do citoplasma da célula ovo, sem o aumento do seu volume, é acompanhada pela abolição do periodo de crescimento entre as divisões. A segmentação dos núcleos ocorre em velocidade muito alta, mais rápida que 
observada em células tumorais (exemplo: um ovo de rã divide-se em 37.000 células em apenas 43 horas). Essa rapidez de divisão clular é especialmente alta durante a clivagem, diminuindo consideravelmente em outras fases do desenvolvimento.

\section{Diferentes tipos de Blástula}

A blástula se apresenta em diferentes tipos, variando de acordo com o teor e com a distribuição do vitelo na célula ovo (VANDERLEY \& SANTANA, 2015). Celoblástula regular e irregular, esterroblástula, periblástula e discoblástula, são exemplos desses diferentes tipos. Para estudos acerca do desenvolvimento embrionário de animais domésticos destaca-se na literatura a "discoblástula", tipica de ovos telolécitos que estão presentes no desenvolvimento de répteis aves como, por exemplo, na Galinha. No entanto, a discoblástula apresenta-se de forma virtual e é representada pela cavidade subgerminal ou pelo espaço que mais tarde surge com a formação de uma segunda camada celular (hipoblasto), mais interna, a qual é separada da mais superficial (epiblasto) (Figura 27).

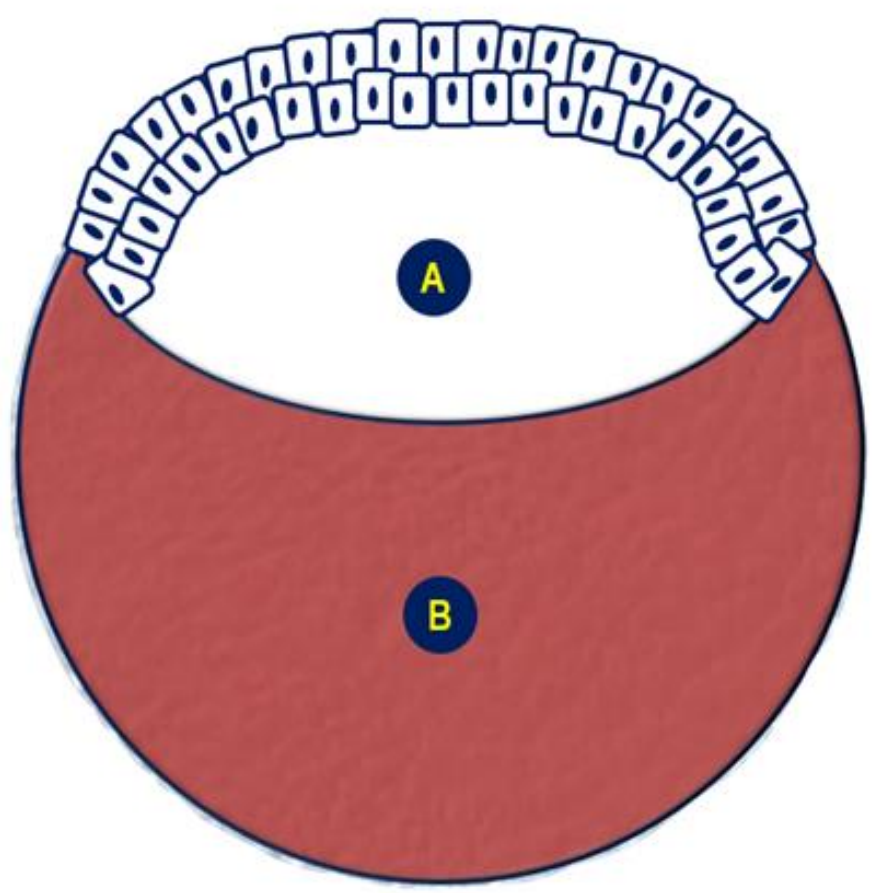

Figura 27. Esquema de um corte de blástula do tipo discoblástula presente no desenvolvimento de Galinha (Gallus gallus domesticus). (A) Região da Blastocele. (B) Região de onde há presença de Vtitelo. Fonte: Assunção (2020). 


\section{Atividades}

a) Defina blastulação com suas palavras.

b) Como a blastulação é provocada?

c) Como são definidas as células presentes no interior da blastocele?

d) A porção volumétrica da célula ovo pouco se modifica ao longo do desenvolvimento de mamiferos e anfibios? Justifique sua resposta.

e) A discoblástula apresenta-se de forma virtual e é representada pela cavidade subgerminal. A partir desta afirmação, este tipo de blástula é típica de qual espécie animal?

\section{Referências}

HYTTEL, P.; SINOWATZ, F. \& VEJSTED, M. Domestic Animal Embryology. 11th ed. Saunders, Elsevier, p.359. 2010.

VANDERLEY, C. S. B. S. \& SANTANA, I. C. H. Histologia e embriologia animal comparada. 2. ed. - Fortaleza: EdUECE, 2015. 

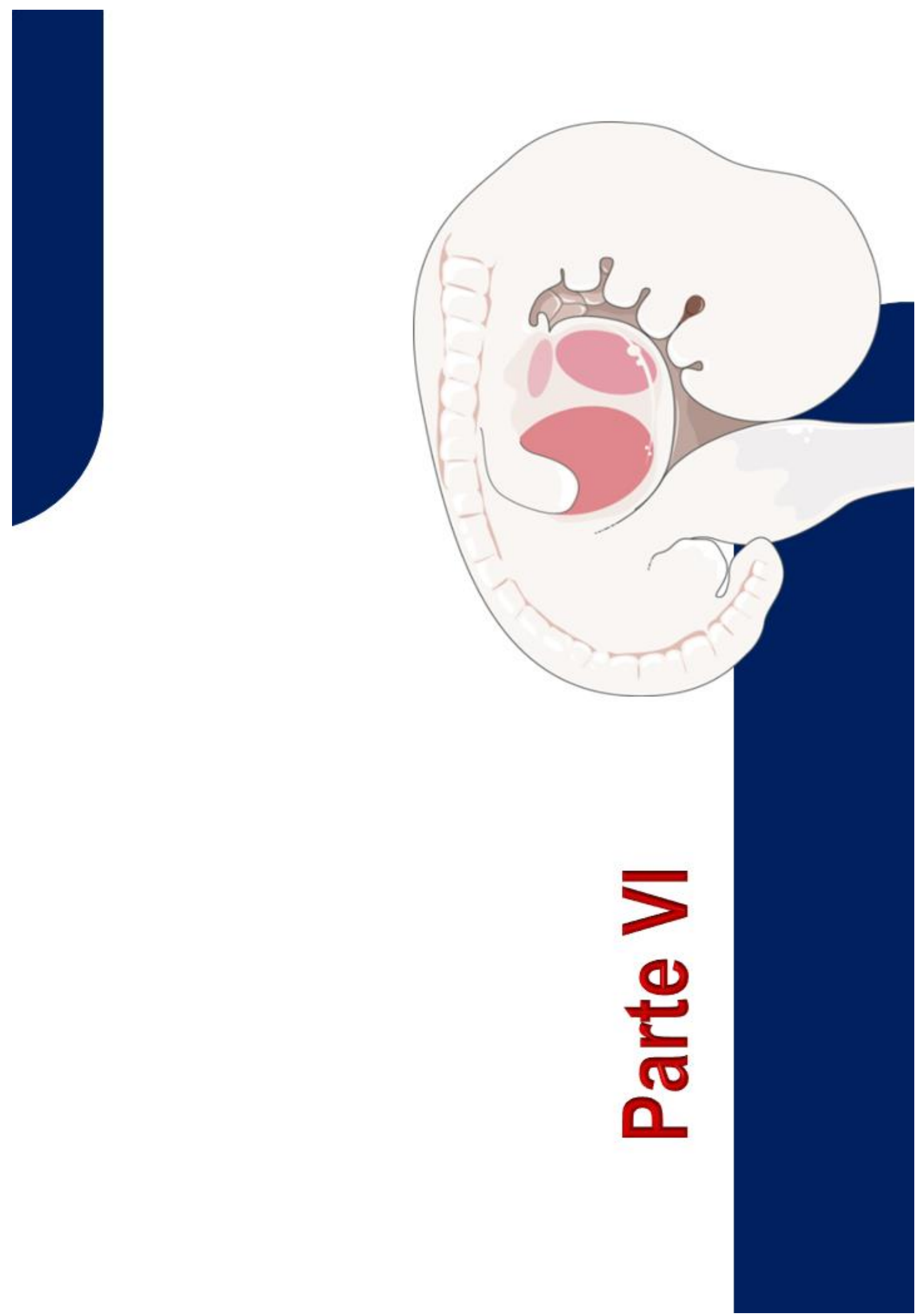


\section{Capítulo}

\section{GASTRULAÇÃO}

\section{Introdução e Conceitos Gerais}

A gastrulação deriva do termo grego gástrula, o qual significa "pequeno estômago". Além das três camadas, a gastrulação também estabelece a linhagem germinativa e, além disso, apresenta uma morfologia de células germinativas primordiais. Como a gastrulação prossegue o seu processo? Então, o disco embrionário é recoberto, de forma gradual, por membranas extraembrionárias para a formação da cavidade amniótica. Em geral, nas espécies domésticas comparativamente, a formação do âmnio resulta dos dobramentos da região superior da trofectoderma com o mesoderma extraembrionário subjacente.

Em aspecto mais detalhado, a gastrulação tem sido tradicionalmente relacionada com a aparência morfológica da linha primitiva (já dito no início da aula), isso é resultado do acúmulo de células alongadas encontradas na região do polo caudal do individuo em desenvolvimento, ou seja, do embrião. Esta estrutura é formada por células do epiblasto que se acumulam na região posterior do embrião, formando uma área espessa em formato de "meia-lua" (Figura 28).

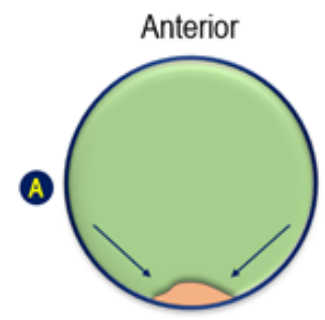

Posterior
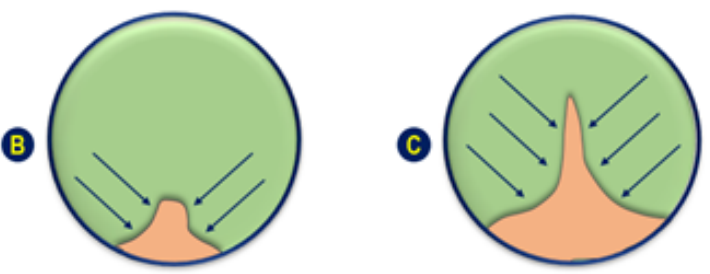

Figura 28. Representação do acúmulo de células epiblásticas presentes na porção posterior do disco embrionário que resulta na formação da linha primifiva. Fonte: Hytel et. al., (2010) modificado Assunção (2020). 
O trofoblasto dará origem ao córion, e o botão embrionário, ao embrião propriamente dito.

As esponjas e os celenterados se desenvolvem a parfir de apenas dois folhetos germinativos, a ectoderme e a endoderme, e são ditos diblásicos. Todos os vertebrados são triblásficos.
No disco embrionário das espécies domésticas, tais como: suino, bovino e aves, o primeiro sinal morfológico do inicio da gastrulação foi possivel ser identificado. O espessamento caudal crescente surge aproximadamente nos dias 10 e 11 da gestação em suinos, e, entre 14 a 15 dias em bovinos. Já em galinha ocorre œrca de 6 a 7 horas de incubação após a fecundação. Após o periodo de estabelecimento da morfologia, tem-se o inicio da entrada de células do epiblasto na cavidade entre o epiblasto e o hipoblasto.

As células do epiblasto que constituem a região posterior em crescimento alongado se unem na linha média do disco embrionário formando a linha primitiva. Nessa linha, as células começam o processo de involução do epiblasto mediante sua membrana basal para formar então os percursores mesoendodermais (mesentoderma), isto é, células capazes de dar origem tanto ao mesoderma quanto ao endoderma.

A formação dos percursores mesentodermais é o primeiro exemplo dando no processo da blastulação para a transição epitélio-mesenquimal durante o desenvolvimento embrionário, processo no qual as células mudam suas caracteristicas de células do epitélio e apresentam fortes conexões intercelulares para se tornarem mais livres, organizadas e capazes de realizar migrações independentemente da camada germinativa de origem. Assim como no inicio, a gastrulação que é marcada pela transição epitélio-mesenquimal, o final torna-se marcado pelo declinio desse processo ao final desta fase.

Os padrões de gastrulação se diferenciam entre as espécies do reino animal. A quantidade e distribuição do vitelo presente no ovo é um dos motivos dessa variação. Sendo o vitelo o percursor para a definição dos movimentos que irão ocorrer. Nos ovos do tipo oligolécitos, a gastrulação é simples e tem seu inicio junto a porção do polo vegetativo. Já nos ovos heterolécitos, ocorre a interferência do vitelo, e o movimento das células vegetativas se torna minimo na fase de gastrulação. A gastrulação inicia-se nas proximidades do equador da blástula, e mecanismos são acionados de forma alternada para a internalização das células vegetais. Nos telolécitos, o polo vegetal não se cliva, e a gastrulação se dá no blastodisco, no polo animal do embrião (GARCIA \& FERNANDEZ, 2001; VANDERLEY \& SANTANA, 2015). 


\section{Tipos de movimentos da gastrulação}

Os movimentos de gastrulação se apresentam nas mais diferentes formas que vão desde a epibolia (ou recobrimento), embolia (ou invaginação), delaminação, imigração, proliferação polar, extensão, involução até a evaginação. Tais movimentos ocorrem de forma isolada, mas o mais comumente visivel, é a ocorrência de pelo menos dois deles que ocorrem simultaneamente. Cinco deles, sendo os mais recorrentes nas várias espécies de animais, são descritos a seguir:

1) Epibolia - Movimento de camadas epiteliais que se expandem como uma unidade, e não individualmente. Neste tipo de movimento, observa-se um achatamento ápico-basal das células, o que torna as células mais baixas, porém mais espessas, levando ao envolvimento das camadas mais profundas do embrião. Esse movimento pode ser observado em anfibios, quando se visualiza os micrômeros presentes no polo animal, e que logo se dividem rapidamente, e recobrem os macrômeros presentes no polo vegetativo.

2) Embolia - Tal movimento consiste em um dobramento para o interior de um conjunto de células, de maneira semelhante à cavidade formada quando se empurra, com o punho, a superficie de uma bola murcha. Tudo se passa como se empurrássemos o polo vegetativo para o interior da blástula. À medida que a região do polo vegetativo vai adentrando na cavidade œlomática, a blastocele vai se obliterando enquanto uma cavidade externa surge, o arquêntero. $O$ folheto que fica no exterior torna-se o ectoblasto; o folheto interno é o endoblasto, que limita a cavidade digestiva inicial ou arquêntero. O orificio da invaginação em torno do qual passam, um dentro do outro, os dois folhetos primordiais, é o blastóporo. Este processo é característico tanto de um ovo de anfioxo quanto de ouriço-do-mar.

3) Delaminação - Na mitose os fusos que ocorrem são do tipo radiais e os planos de segmentação à superficie do ovo, são paralelos. A blástula uniestratificada transforma-se em um germe de dupla camada celular. $\mathrm{O}$ que muitas vezes permite a produção de delaminações sucessivas. Já as œélulas internas acabam por formar um folheto endoblástico continuo que envolve a cavidade digestiva. Não há blastóporo; a cavidade arquentérica abre-se secundariamente, evento encontrado nos celenterados 
4) Involução - Movimento ocasionado mediante a expansão e a interiorização da camada externa, onde ocorre o dobramento sobre si mesma, de modo a se estender na superficie interna das células externas remanescentes, em sentido contrário ao das últimas.

5) Imigração - Movimento que consiste na migração de células individuais da camada superficial para o interior do embrião em desenvolvimento. As células da blástula migram individualmente e de forma ativa para o interior do individuo. As células passam a ser livres, o que permite a sua disposição para constituir os folhetos internos. Tais folhetos podem ser tipo compacto insinuando sob o ectoblasto. Uma imigração desse tipo é observada durante a gastrulação dos vertebrados superiores, sendo bem característico na formação do mesênquima primário do ouriço-do-mar.

\section{Período embrionário de gastrulação nos mamíferos}

Ao longo da porção média da linha primitva, devido à invaginação das células ectodérmicas, forma-se 0 sulco primívivo, e, no nó primitivo, forma-se a fosseta primifva.

A notocorda é uma estrutura que possui funçōes importantes no desenvolvimento embrionário. Ela é o principal propulsor de uma série de episódios de indução que acabam por transformar células embrionárias não especializadas nos tecidos e órgãos definíivos do adulto. A notocorda induz a diferenciação da ectoderme para formar a placa neural, que dará origem ao sistema nervoso; serve de base para a formação da coluna vertebral ao seu redor; e está relacionada com a formação de alguns ossos do crânio, das costelas e do esterno.
Na porção caudal da face superior do disco embrionário, o epiblasto, devido à sua grande proliferação e migração no sentido caudo-mediano, espessa-se, e surge a linha primitiva que cresce em direção cefálica pela linha mediana. Surge, na extremidade cefálica da linha, uma área mais elevada, o nó primitivo (ou nó Hensen).

As células epiblásticas, em proliferação, que chegam à linha primitiva mudam de forma e adquirem um formato de garrafa. A partir disso, destacam-se do epiblasto e se invaginam entre este e o hipoblasto, constituindo o mesoderma intraembrionário. Uma parte dessas células em invaginação vai posicionar-se entre as células do hipoblasto, deslocando-as e substituindo-as, o que possibilita a formação da endoderme. As células epiblásticas que não penetram pela linha primitiva originam a ectoderme

À medida que mais e mais células ganham seu interior e se deslocam na cavidade entre o epiblasto e o hipoblasto, elas começam a disseminar-se cranialmente e lateralmente, ultrapassando a margem do disco germinativo adentrando em contato com as mesodermes esplancnopleural e somotopleural extraembrionárias 
Do local de fusão dos três folhetos, ou seja, do nó primitivo, parte um cordão celular mediano de mesoderme em direção a região cefálica, a qual embriologicamente é denominado de processo notocordal. Tal cordão passa a adquirir uma cavidade tubular (ou canal notocordal), que se desemboca na fosseta primitiva. $\mathrm{O}$ processo notocordal cresce na direção œfálica, entre a ectoderme e a endoderme, atingindo a placa pré-cordal.

0 endoderma intraembrionário do saco vitelinico ao se fundir com o assoalho do processo notocordal, posteriormente se rompe e desaparece, ocasionando a formação da placa notocordal. 0 tubo neural formado a partir do ectoderma inclui a entrada da fosseta primitiva (ou canal notocordal) em seu assoalho, estabelecendo uma comunicação entre o intestino primitivo e o tubo neural (chamado de canal neurentérico de existência passageira). Mais tarde, as células da placa notocordal se proliferam a começar pela extremidade cefálica do embrião propriamente dito Posteriormente, a placa entre em processo de dobramento e forma um bastão celular, denominado de notocorda e seu crescimento se dá em direção caudal.

Com rapidez e semelhança ao processo que ocorre nos sauropsideos e nos anfibios, a mesoderme se desenvolve, e a partir dela ocorre a formação somitica e de mesênquima. Ao final a, a mesoderme ocupa todo o disco embrionário entre a ectoderme e a mesoderme, exceto nas regiões das placas pré-cordal e cloacal, nas regiões caudal e cefálica, respectivamente.

\section{Atividades}

a) Defina, com suas palavras, gastrulação.

b) Cite três movimentos de gastrulação e descreva como eles ocorrem de forma sucinta.

c) Faça uma resenha do assunto tratado neste capitulo. 
d) Formule três questões subjetivas sobre o assunto deste capitulo e responda-as.

e) Formule três questões objetivas sobre $o$ assunto deste capitulo $e$ responda-as.

\section{Referências}

GARCIA, S. M. L.; FERnANDEZ, C. G. Embriologia. 2. ed. Porto Alegre: Artmed, 2001. cap. 8 e 9 , p. $110-126$.

HYTTEL, P.; SINOWATZ, F. \& VEJSTED, M. Domestic Animal Embryology. 11th ed. Saunders, Elsevier, p.359. 2010.

VANDERLEY, C. S. B. S. \& SANTANA, I. C. H. Histologia e embriologia animal comparada. 2. ed. - Fortaleza: EdUECE, 2015. 

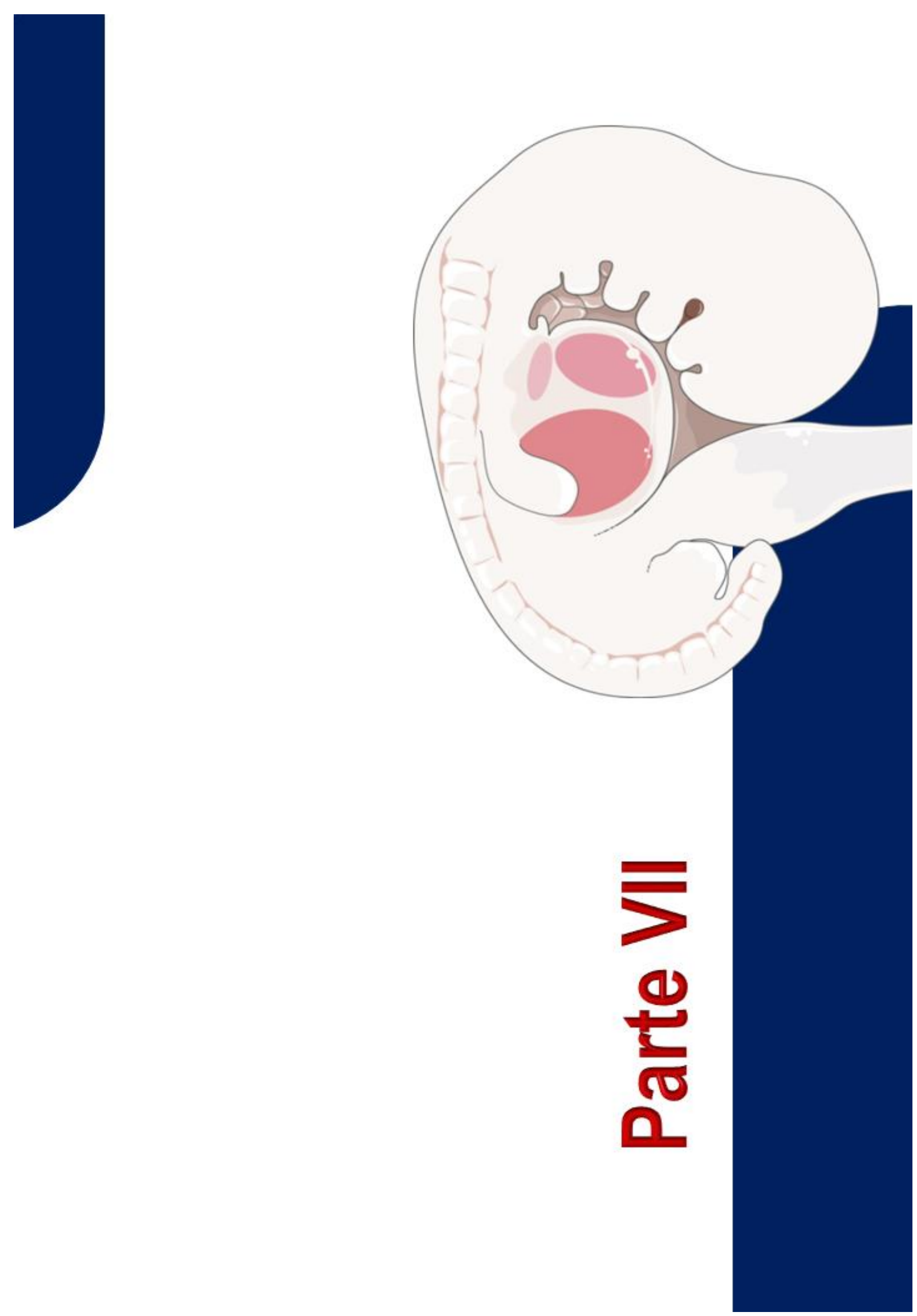


\section{Capítulo 7}

\section{Introdução e Conceitos Gerais}

A gástrula é transformada em nêurula mediante a ocorrência dos processos denominados de neurulação. Tais eventos coincidem com a formação das camadas germinativas, como já descritas no capitulo anterior. Alterações da forma corpórea das camadas germinativas resulta na diferenciação inicial entre a endoderme e a mesoderme.

Nesse interim, a neurulação é fundamental no processo da embriogênese. Ela consiste na formação e no desenvolvimento da placa neural e das pregas neurais com a consequente formação do tubo neural, o precursor do sistema nervoso central (sistema que inclui o cérebro e a medula espinal). A sua formação varia de acordo com cada espécie animal, mas este sistema de órgãos oriundos de um tubo oco neuroectodérmico é o primeiro a iniciar seu desenvolvimento no organismo. Funcionalmente falando, tal sistema é ultrapassado pelo desenvolvimento do sistema cardiovascular, sendo este o primeiro sistema a ganhar sua função no embrião.

\section{Formação do tubo neural e suas respectivas ocorrências}

As células do mesoblasto se estendem para frente, na linha mediana, desde a extremidade caudal da linha primitiva, o que possibilita a formação da notocorda. Tal formação tem a importante função de induzir o espessamento da ectoderme logo na extremidade superior, formando a placa neural (o crescimento da placa neural se dá em direção à linha primitiva, cefalocaudal).

Ao decorrer do surgimento das pregas neurais, a parte œntral da placa neural se aprofunda, permitindo que haja a formação do sulco neural. O sulco continua adentrando a placa neural, formando um aspecto de invaginação, e as margens da

Os termos epiblasto, hipoblasto, ectoblasto, mesoblasto, endoblasto, ectoderme, mesoderme e endoderme são ufilzados, e devem ser respeitados, para resguardar a potencialidade e a diferenciação dos folhetos nos diferentes graus de maturação celular observados durante 0 desenvolvimentos embrionário.

As pregas neurais se fundem primeiro na região do pescoço e avançam nas direçöes cefálica e caudal.

Em partes dos grupos de animais

(exceto aves e mamiferos), a notocorda e a placa neural são determinadas, nos estágios iniciais, por células precursoras. 
placa acabam se fundindo na linha mediana.

Nesse interim, o tubo neural formado no decorrer do desenvolvimento embrionário envolve a neurocele, caracterizando a corda nervosa dorsal oca de todos os animais vertebrados. Enquanto as pregas neurais não fundem completamente, as extremidades, cefálica e caudal, do tubo neural, comunicam-se com a cavidade amniótica mediante a presença de neuróporos (cefálico e caudal, respectivamente).

No decorrer do processo da neurulação, algumas células imediatamente laterais à placa neural são delaminadas, dando origem às cristas neurais. As células livremente se agregam nas reentrâncias entre o tubo neural (que se invagina), e da ectoderme ao redor. Quando o tubo neural se fecha completamente, as cristas neurais ficam fundidas a ele, porém, por pouco tempo, pois elas se separam e migram, individualmente, por boa parte do corpo, induzindo a formação de outros tecidos. Após a formação do tubo neural, a camada de ectoderme cutânea (de revestimento) fundese na linha média, cobrindo por completo o tubo neural.

Mais tarde no processo da neurulação, a região anterior (œfálica) do tubo neural se encontra em uma morfologia espessada apresentando diversas dilatações (as vesiculas encefálicas), enquanto a região caudal é mais estreita possibilitando a formação da medula espinal. Com o avançar do estágio da neurulação, os embriões derivados da segmentação (ou clivagem) total ficam mais alongados, de forma que uma cabeça e uma cauda são definidas. No que se refere as células, ricas em vitelo, as mesmas podem sofrer o processo de distensão na região do abdômen, mas são limitadas pelo contorno do corpo.

Os embriões derivados da segmentação parcial, por exemplo, as aves domésticas, em um determinado momento do desenvolvimento, podem ser vistas como três camadas germinativas estendidas, "com a face voltada para baixo", sobre o vitelo sem segmentação, se envolvendo. Tais processos descritos acima podem ser observados mediante o esquema didático da figura 29.

Em alguns grupos de animais (exceto aves e mamiferos), a notocorda e a placa neural são determinadas, nos estágios iniciais, por células Precursoras fundamentais no desenvolvimento embrionário. 


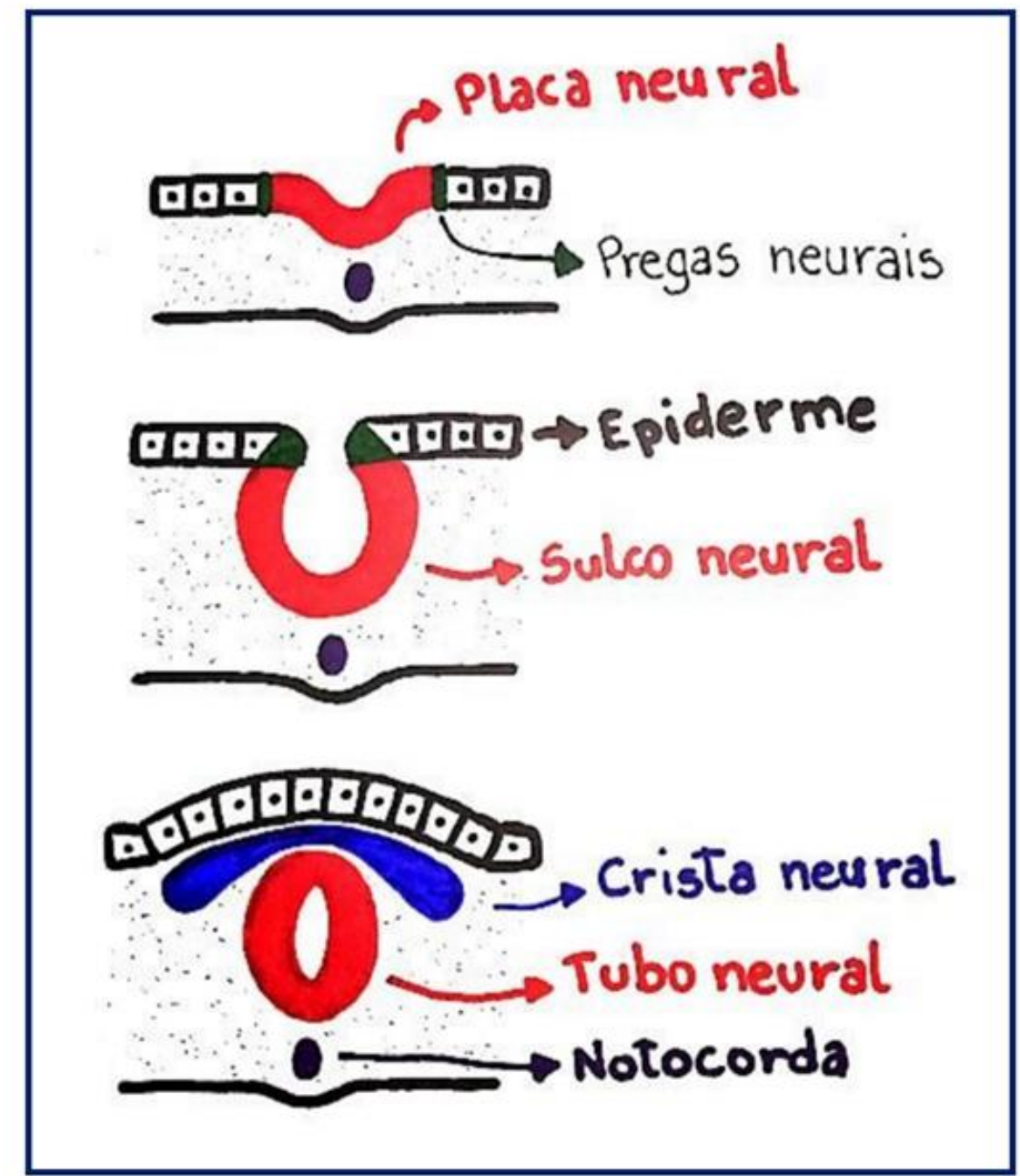

Figura 29. Crista neural e formação do tubo neural em fase do desenvolvimento de animais cordados. Fonte: Ciência em minutos (2020).

\section{Processo da neurulação em aves domésticas}

Nas aves domésticas (Gallus gallus domesticus), as células ectodérmicas migram para face externa do blastodisco para envolver o vitelo em um processo de epibolia. Este enclausuramento do vitelo é requer uma demanda que envolve a produção continua de material celular e a migração das células ectodérmicas presuntivas ao longo da superficie inferior do envoltório vitelinico. 
Ao chegar ao fim da gastrulação, a ectoderme envolve o vitelo, a endoderme substitui o hipoblasto e a mesoderme se posiciona entre essas duas regiões (GILBERT, 2003; VANDERLEY \& SANTANA, 2015). O embrião que se originou na blastoderme sofre intensas modificações em sua morfologia, passando de discoide para uma forma alongada em formato tubular

Assim, dobras envoltas no embrião surgem, elevando o mesmo acima do vitelo. A dobra anterior (para baixo e em direção caudal) surge primeiramente e depois uma caudal (em direção cefálica). Posteriormente, dobras laterais surgem. Estas últimas ocorrem em direção à linha mediana do corpo do individuo. Entretanto, tais movimentos tornam o embrião tubular e lhe conferem a conformação apresentada no individuo adulto

Os processos descritos acima são denominados de delimitação do corpo do embrião. Deste modo, a modelagem do corpo do embrião é acompanhada pela formação de estruturas temporárias resultantes da extensão dos folhetos germinativos, ou seja, os anexos embrionários: saco vitelinico, âmnio e alantoide. A córion neste processo é constituida pela membrana externa do âmnio. Tal membrana fica em intimo contato com as membranas da casca do ovo, e, devido a isto, mobiliza minerais da casca para a construção do esqueleto do futuro organismo, bem como tem papel fundamental na respiração. Alguns autores consideram a córion como um quarto anexo embrionário presente nas aves domésticas

\section{Atividades}

a) Defina neurulação com suas palavras.

b) Cite um dos processos envolvidos na neurulação e descreva como ele ocorre de forma sucinta.

c) 0 destino do tecido que forma a placa neural é apenas um? Se sim, justifique sua resposta.

d) A invaginação da parte central na placa neural em aves domésticas, por exemplo, resulta na formação de qual estrutura? 
e) Prepare um plano de aula sobre este assunto. Leve em consideração que uma aula para o Ensino Superior tem aproximadamente 50 minutos.

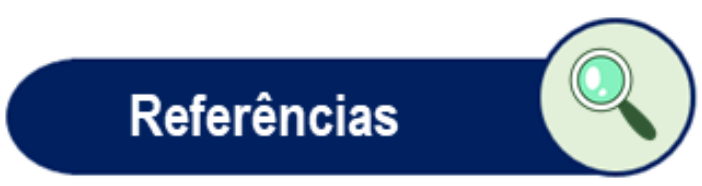

GILBERT, S. F. Biologia do desenvolvimento. 5. ed. São Paulo: FUNPEC, 2003. $918 \mathrm{p}$.

HYTTEL, P.; SINOWATZ, F. \& VEJSTED, M. Domestic Animal Embryology. 11th ed. Saunders, Elsevier, p.359. 2010.

VANDERLEY, C. S. B. S. \& SANTANA, I. C. H. Histologia e embriologia animal comparada. 2. ed. - Fortaleza: EdUECE, 2015. 

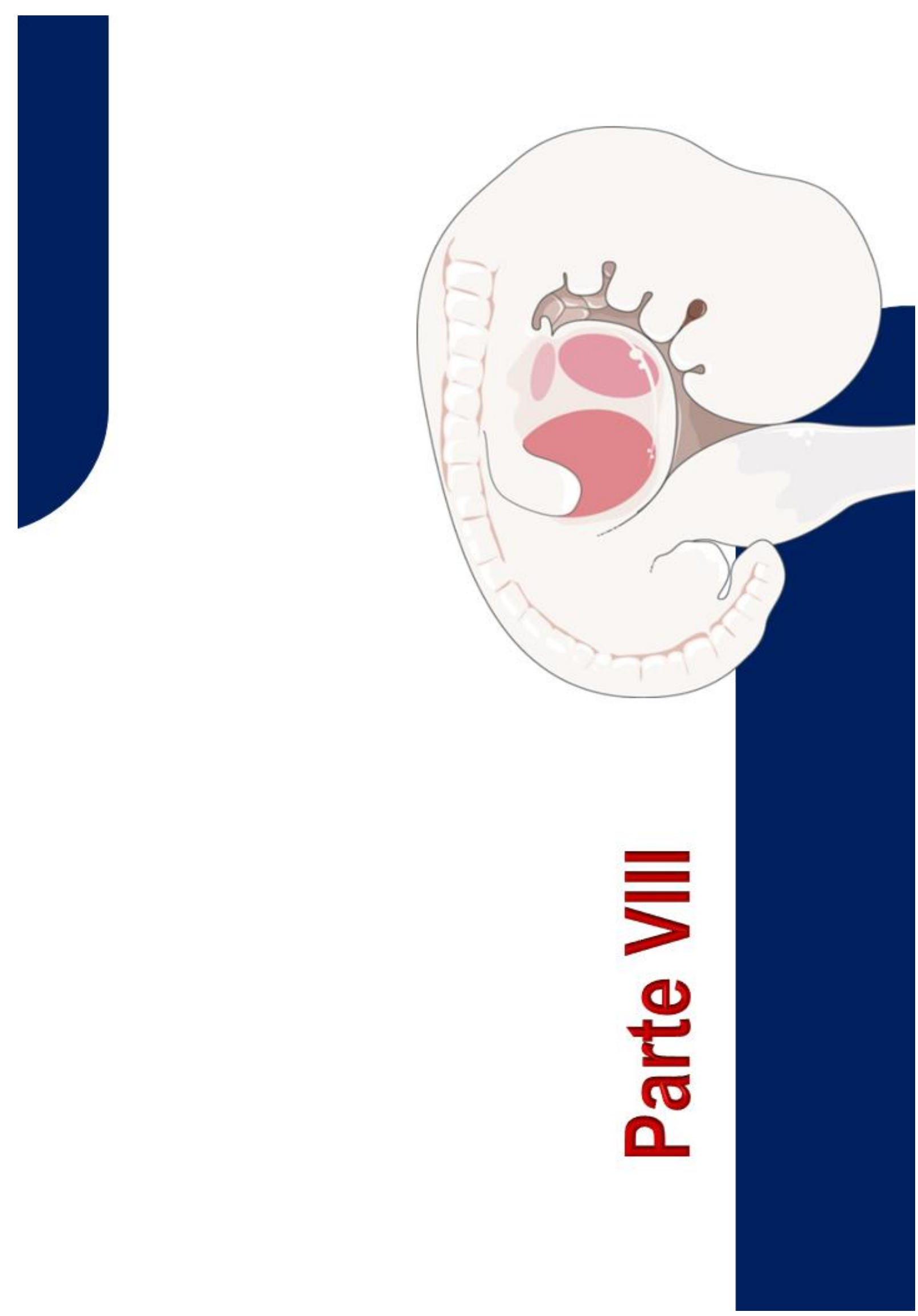


\section{Capítulo}

\section{ORGANOGÊNESE}

\section{Introdução e Conceitos Gerais}

Os folhetos germinativos assumem uma organização morfológica e estrutural ao final da gastrulação, porém, algumas camadas celulares ainda não apresentam sua diferenciação, necessitando adquirir sua caracterização. Uma vez ordenados os tecidos, esses territórios organoformadores diferenciam-se histologicamente, ou seja, os tecidos associam-se para constituir órgãos. Uma vez diferenciados os tecidos num órgão, ele passa atingir seu estado funcional.

Neste contexto, a organogênese é definida na embriologia como o processo responsável pelo o desenvolvimento no qual os três folhetos embrionários, ou seja, o ectoderma, mesoderme e endoderme se diferenciam e dão origem aos órgãos internos como, por exemplo, o coração. É nessa fase do desenvolvimento que ocorrem divisões e especializações celulares fundamentais para formação do futuro organismo. Alguns eventos que chamam atenção nesta fase é a formação do tecido neural dos somitos, bem como o estrangulamento do saco vitelinico resultando na formação do intestino.

\section{Ocorrências envolvidas no processo da organogênese}

Os movimentos morfogenéticos não terminam após o estágio da gastrulação. Outros movimentos ocorrem neste periodo para dar a forma anatomofisiológica ao embrião. Ao conjunto desses movimentos morfogenéticos, incluindo os da gastrulação, denomina-se morfocoresis, movimentos que se apresentam de forma variável entre as espécies de animais. Uma vez ordenados os tecidos, esses territórios organoformadores se diferenciam, como já mencionado no inicio do capitulo. 
Quando os órgãos atinge seu estado vital (ou funcional), o embrião se torna capaz de levar uma vida livre. Isto é mais nitidamente observado no caso dos individuos aquáticos que possuem fase larvar, ocorrendo a eclosão neste momento (ele se torna larva). O embrião chega, então, à sua fase de atividade funcional, que marca o fim do periodo embrionário.

\section{Diferenciação dos tecidos}

A diferenciação das células relativamente indiferenciadas de cada um dos três folhetos germinativos, para formar células teciduais especializadas, é chamada histogênese. Neste sentido, torna-se necessário que haja ocorrências de várias alterações morfológicas e de expressão gênica. Uma vez que uma célula tenha alterado a expressão de seu genoma para assumir função mais especializada, diz-se que ela é predestinada. Cada um dos três folhetos germinativos é destinado a formar certos tipos de tecidos. A diferenciação ocorre à medida que as células assumem aparência e funções caracteristicas do tipo de células a que elas estão destinadas.

A ectoderme, por exemplo, origina a ectoderme mais externa (ou somática), que irá formar determinadas estruturas do corpo do animal e o ectoderma neural (ou sensorial), que terá destino diferente. Com algumas poucas exceções, a mesoderme forma os sistemas muscular, esquelético, cardiovascular e os órgãos urogenitais. A cordomesoderme contribui na formação da notocorda. A mesoderme deriva principalmente do arquêntero e da linha primitiva, e rodeia a notocorda. $\mathrm{Na}$ mesoderme, observam-se inicialmente três porções, a mesoderme para-axial, intermediária e lateral:

a) Mesoderme para-axial: local em que as células mesodérmicas, de cada

Na morfocoresis, É possivel notar, por exemplo,

movimentos que levam à diferenciação da ectoderme naquela de revestimento e na neural. 0 mesoblasto divide-se em blocos regulares na maioria dos cordados, e em formações axiais, como a do tubo nervoso. lado da notocorda, condensam-se em uma série de massas emparelhadas em forma de blocos, os somitos, dispostos em segmentos que se desenvolvem em vértebras e em músculos. O somito se diferencia ainda mais em dermátomo (lateral), miótomo (central) e esclerótomo (mediano). O dermátomo se torna um mesênquima que se dispersa, formando a derme da pele e alguns tecidos duros presente no corpo do animal. O miótomo forma músculos da coluna vertebral, a garganta e boa parte dos 
músculos e do esqueleto apendicular. O esclerótomo forma uma porção, maior ou menor, das vértebras, dependendo dotáxon.

b) Mesoderme intermediária: localizada lateralmente aos somitos, possibilitando a origem dos órgãos urogenitais

c) Mesoderme lateral: constitui a parte lateral do mesoderma, entretanto, divide-se em duas camadas, formando uma cavidade, o celoma. O celoma vai finalmente tornar-se as cavidades torácica, abdominal e pélvica. A camada externa do mesoderme da lateral e o ectoderma adjacente compõem a somatopleura, que forma parte da parede do corpo e entra na formação das membranas fetais. A camada interna do mesoderme lateral e o endoderma formam a esplancnopleura, que origina a parede intestinal.

A endoderme constitui a face ventral do disco germinativo e continua seu desenvolvimento para parte externa, revestindo internamente o saco vitelínico. Do saco originam diferentes órgãos, porém o trato gastrintestinal é o principal sistema derivado desta camada. Sua formação é dependente de dobramentos cefalocaudal e lateral do concepto. Em consequência a estes movimentos de dobramento, a comunicação entre o embrião e o saco vitelinico, inicialmente amplo, sofre constrição progressiva até a formação do ducto vitelinico. Assim, uma porção maior da cavidade revestida por endoderma é incorporada pelo embrião propriamente dito. Este dobramento leva à formação de três segmentos intestinais, sendo o mais cranial denominado de intestino anterior, medialmente, intestino médio; e caudalmente, o intestino posterior.

No quadro 5 é possivel observar os derivados dos folhetos germinativos embrionários nos cordados.

Quadro 5. Esquema dos derivados dos folhetos germinativos embrionários nos animais cordados (Vanderley \& Santana, 2015).

\begin{tabular}{|c|c|c|}
\hline Folhetos germinativos & Formações embrionárias & Tecidos e órgàos \\
\hline \multirow{3}{*}{ Ectoderme } & Ectoderme somática & $\begin{array}{l}\text { Epiderme e estruturas epidérmicas (glândulas, } \\
\text { pelos, unhas, penas etc.), esmalte dos dentes, } \\
\text { revestimento das cavidades bucal e nasal, e da } \\
\text { cloaca (parte), medula adrenal, adeno-hipófise. }\end{array}$ \\
\hline & \multirow[t]{2}{*}{ Ectoderme neural } & $\begin{array}{l}\text { As cristas neurais formam: as raizes dorsais ou sensitivas } \\
\text { dos nervos espinhais; dos gânglios sensoriais de quatro } \\
\text { nervos cranianos; gânglios simpáticos e células de } \\
\text { Schwann, cromatóforos; elementos cartilaginosos } \\
\text { do complexo branquial, medula adrenal etc. }\end{array}$ \\
\hline & & $\begin{array}{l}\text { Tubo neural - sistema nervoso central (encéfalo } \\
\text { e medula espinhal); cristalino e retina. }\end{array}$ \\
\hline
\end{tabular}




\begin{tabular}{|c|c|c|}
\hline \multirow[b]{2}{*}{ Mesoderme } & Cordomesoderme & Notocorda, posteriormente é circundada pelas vértebras. \\
\hline & $\begin{array}{l}\text { Somitômeros Mesoderma } \\
\text { dorsolateral da cabeça) }\end{array}$ & $\begin{array}{l}\text { Músculos extrinsecos do olho, músculos da } \\
\text { face e da faringe e seus derivados. }\end{array}$ \\
\hline \multirow{5}{*}{ Mesoderme } & Mesênquima & $\begin{array}{l}\text { Esqueleto; tecidos conjuntivos e outros de sustentação; } \\
\text { músculos da cabeça; aparelho circulatório } \\
\text { (coração, vasos e sanque); e parte da derme. }\end{array}$ \\
\hline & \multirow{3}{*}{$\begin{array}{l}\text { Somitos } \\
\text { (epimeros) }\end{array}$} & Dermátomo - grande parte da derme e seus derivados. \\
\hline & & Esclerótomo - Vértebras, em parte. \\
\hline & & $\begin{array}{l}\text { Miótomo - Grande parte dos músculos (voluntários) } \\
\text { axiais e dos membros e esqueleto. }\end{array}$ \\
\hline & $\begin{array}{l}\text { Mesoderma intermediário } \\
\text { (mesômero) }\end{array}$ & Orgãos do sistema urogenital. \\
\hline Mesoderme & $\begin{array}{l}\text { Mesoderme lateral } \\
\text { (hipömero) }\end{array}$ & $\begin{array}{l}\text { Camada somática - Parte dos músculos axiais e dos } \\
\text { membros e esqueleto. } \\
\text { Camada esplâncnica - músculos involuntários do aparelho } \\
\text { digestório e peritônio e mesentérios e coração. } \\
\text { Parte do aparelho reprodutor. }\end{array}$ \\
\hline & Endoderme primária & Células germinativas. \\
\hline Endoderme & Endoderme definitiva & $\begin{array}{l}\text { Sistema digestório e glàndulas anexas (figado e pâncreas); faringe; } \\
\text { pulmão; ouvido médio; algumas glàndulas endocrinas (tireoide, } \\
\text { timo e paratireoides); Epitélios do tubo digestivo (exceto boca } \\
\text { e canal anal), do sistema respiratorio, da bexiga e da uretra. }\end{array}$ \\
\hline
\end{tabular}

\section{Atividades}

a) Defina organogênese com suas palavras.

b) Cite três órgãos formados a partir de cada um dos folhetos germinativos presentes ao longo do desenvolvimento embrionário.

c) Faça um esquema didático indicando a esplancnopleura e a somatopleura.

d) A morfocoresis apresenta-se movimentos variáveis entre os grupos de animais? Justifique sua resposta.

e) A partir de qual momento do processo da organogênese os órgãos atingem seu estado funcional no embrião? 
Referências

HYTTEL, P.; SINOWATZ, F. \& VEJSTED, M. Domestic Animal Embryology. 11th ed Saunders, Elsevier, p.359. 2010.

VANDERLEY, C. S. B. S. \& SANTANA, I. C. H. Histologia e embriologia animal comparada. 2. ed. - Fortaleza: EdUECE, 2015. 

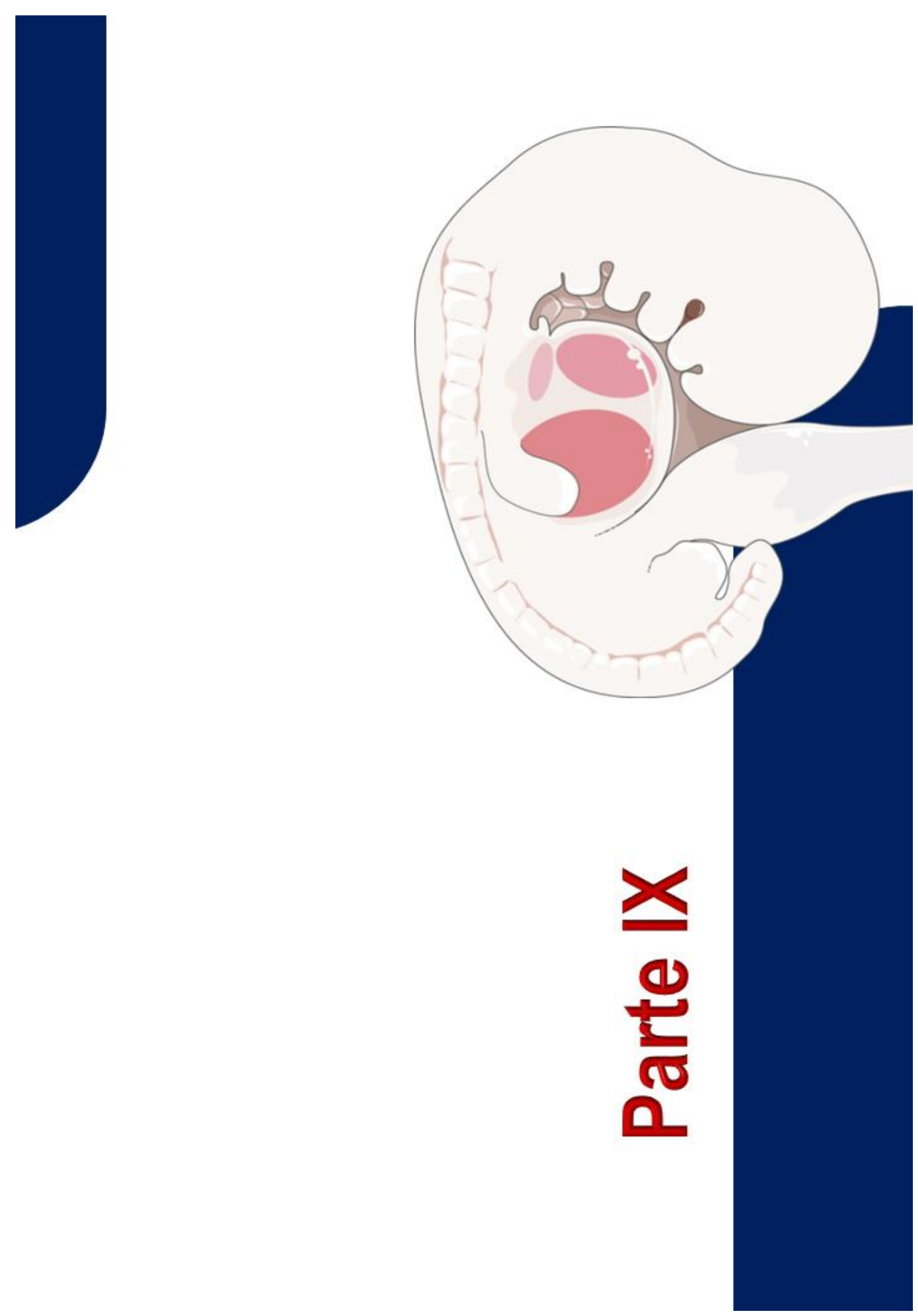


\section{Capítulo}

\section{DESENVOLVIMENTO DO SISTEMA CARDIOVASCULAR}

\section{Introdução e Conceitos Gerais}

O sistema cardiovascular é formado por um conjunto de tubos conectados responsáveis pelo transporte de fluidos, incluindo a rede vascular do sangue e da linfa. Este sistema, por sua vez, é constituido pelo sangue, vasos e coração. Na sua embriologia, o coração, em formato de tubo, apresenta batimentos autônomos ritmicos conduzindo o sangue mediante o sistema de vasos em formação. Nesse interim, tal sistema é o primeiro a atingir o estado funcional no organismo em desenvolvimento, já a sua diferenciação e crescimento dependem do transporte interno no embrião.

Quando o coração embrionário já está formado, duas camadas se apresentam, sendo estas um endocárdio interno e um epimiocárdio externo. Em linhas gerais, no coração maduro, o endocárdio apresenta uma camada espessa de tecido conjuntivo elástico, revestido por tecido endotelial. Assim, quando o epimiocárdio atinge seu estado maduro, possibilita a origem de um epicárdio externo, formando a partir dai a membrana serosa que envolve o órgão e o músculo do coração, o miocárdio.

Em sua fisiologia normal, o coração é a bomba responsável por estimular o movimento sanguineo por todo o sistema cardiovascular, incluindo também como função o transporte do sangue desoxigenado e oxigenado para suas partes apropriadas evitando a mistura dos sangues, bem como o transporte de hormônios do seu local de origem para os tecidos alvos.

Nos animais domésticos, por exemplo, o coração primitivo encontra-se localizado ventralmente ao corpo dos animais. Como este grupo de cordados (ou vertebrados) apresentam diversas adaptações anatômicas, variando de acordo com a biologia, ecologia e habitat; nas espécies de aves domésticas como é o caso de Gallus gallus domesticus que adotaram a posição bipede, o coração encontra-se localizado na região "anterior" do corpo. 
Compreender as correlações anatomofisiológica cardiaca é fundamental no estudo evolutivo acerca dos animais vertebrados, assim como as suas estruturas adjacentes. Neste contexto, entender também a dinâmica cardiaca nas mais diferentes espécies domésticas permite o desenvolvimento e aprimoramento de técnicas voltadas para a clínica cirúrgica como transplante cardiaco, e pesquisas sobre regeneração cardiaca.

\section{Desenvolvimento do coração, vasos e sua morfologia}

De origem mesodérmica esplânica, o coração tem inicio nos cordões angioblásticos que se canalizam e formam os tubos endocárdios. Em formato tubular, sua parede interna é revestida pelo endocárdio, os músculos revestidos pelo miocárdio e sobre o órgão há um revestimento fribroseroso

O coração tubular se alonga e em formato de ferradura, após o dobramento embrionário, reposiciona dentro da cavidade pericárdica ventral ao disco embrionário dando origem a formação do tronco arterioso, bulbo cardiaco, ventriculo, átrio e seio venoso

O alongamento ocasionado nas porções anteriores do tubo se desenvolvem em aortas ventrais enquanto que a porção posterior entra em contato com o sistema venoso em desenvolvimento. Paralelamente a prega anteroposterior, um dobramento lateral move as pregas laterais do disco germinativo em direção a linha mediana do concepto.

De forma gradual as porções posteriores das aortas ventrais são aproximadas mediante a presença da prega lateral até a altura do intestino anterior. No entanto, as porções das duas aortas ao se fusionarem neste processo formam um tubo único se estendendo anteriormente ao tubo cardiaco.

A figura 30 apresentada a seguir, traz os estágios progressivos do desenvolvimento das aortas dorsais e ventrais, bem como o posicionamento do coração e as respectivas estruturas envolvidas neste estágio. 


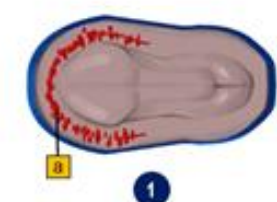

-
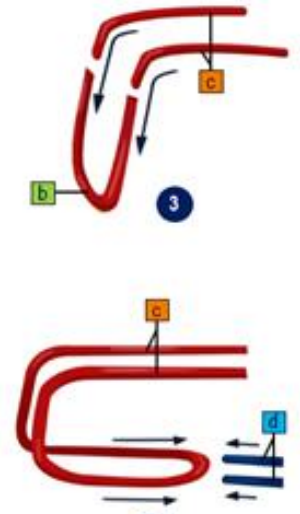

(5)

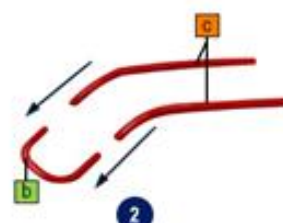

(2)
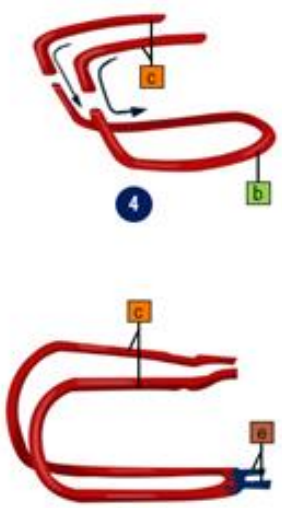

(-

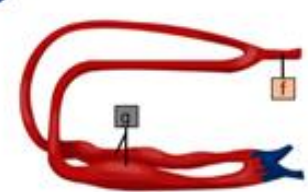

(1)
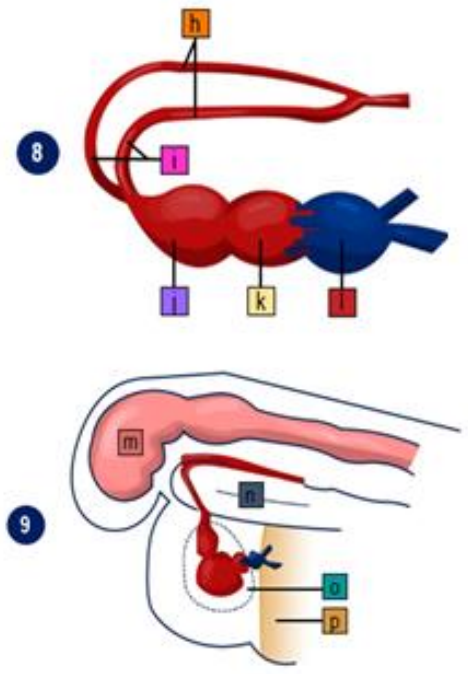

\section{FASE I}

VISTA DORSAL DO EMBRIÃO

a Região cardiogênica

DOBRA CRANIOCAUDAL DO EMBRIÃO

b Tubo cardiaco

c. Aortas dorsais

\section{FASE II}

TUBO CARDIACO

c. Aortas dorsais

d Veias vitelinas

e. Fusão da porção caudal

f Fusão da aorta dorsal

g. Fusão das duas porções do tubo

\section{FASE III}

SISTEMAARTERIAL COMPLETO

Th Aortas dorsais

ii Aortas ventrais

CORAÇÃO EM DESENVOLVIMENTO

ii. Formação do tubo arterioso

k. Formação ventricular

III Formação atrial

VISÃO GERAL DO DESENVOLVIMENTO

m Vesiculas cerebrais

n Intestino primitivo

a Cavidade pericárdica

D. Septo transverso

Figura 30. llustração dos estágios progressivos do desenvolvimento das aortas dorsais ventrais, bem como o posicionamento do coração. Fonte: Hytel et. al., (2010) modificado Assunção (2020). 
O tubo cardiaco em sua extremidade anterior torna-se alinhado com as duas aortas ventrais, o que define as saidas do coração. Já a sua extremidade posterior torna-se unida com o sistema venoso, o que permite definir as entradas do coração. 0 bombeamento sanguineo para as aortas ventrais se dá após a expansão em diâmetro do tubo cardiaco, assim o sangue é distribuido por todo o sistema de arco aórtico, bem como para aortas dorsais. Os batimentos coordenados do coração embrionário iniciam-se por volta do dia 22 do desenvolvimento em suinos, do dia 23 em cães e bovinos, do dia 24 em equinos e do dia 2 em galinha.

Neste estágio do desenvolvimento, o coração nas mais diferentes espécies domésticas consiste em um tubo simples. Nos mamiferos, o tubo cardiaco antes de formar as quatro câmaras sofre uma volta em loop (ou laço) permitindo a ocorrência de uma divisão interna. Deste modo, algumas porções do tubo cardiaco se expandem o que resulta em um tubo segmentado com separação de dilatações por reentrâncias.

Posteriormente a expansão do tubo cardiaco, suas porções passam a ser chamadas seios venosos, é a partir daqui que os vasos se abrem dentro do tubo, com definição do átrio, ventriculo, bulbo e tronco arterioso, possibilitando a saida da aorta ventral. Assim, o tubo cardiaco cresce para fora da cavidade pericárdica, sendo fixado ao pericárdio nas extremidades.

Um formato de $\mathrm{U}$ com curvatura acentuada da junção entre o ventrículo e o bulbo arterioso é direcionada ventralmente. Com uma morfologia proeminente, a curvatura forma a protuberância cardiaca claramente visivel macroscopicamente no embrião, sendo este fato, característico desta fase do desenvolvimento dos animais domésticos. Durante todo esse processo, o coração propriamente dito ao longo do desenvolvimento, bate a um ritmo determinado por marca-passo no seio venoso. Ainda não inclusos na cavidade, o seio venoso e o átrio se torna gradualmente envolto pelo pericárdio.

À medida que inicia a formação das voltas, o tubo cardiaco apresenta paredes lisas e as regiões em cada lado do forame interventricular primário desenvolve trabéculas. Assim, a porção trabeculada do ventrículo da origem ao futuro ventriculo direito. Os aspectos ventrais e esquerdos da segmentação envolvidos na formação do coração podem ser observados por meio da figura 31-1 e 31-2. 


\section{FASE VI}
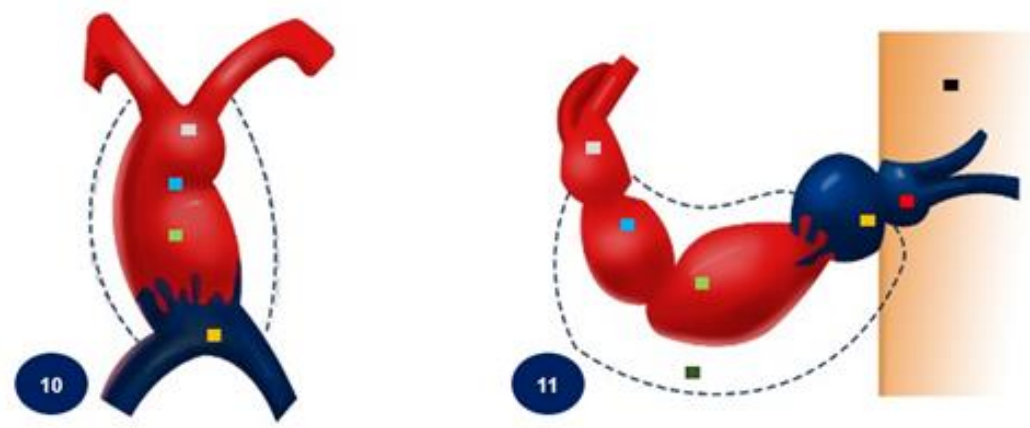

\section{VENTRAL}

Tronco arterioso

Bulbo arterioso

Ventrículo

Átrio

\section{ANTIMERO ESQUERDO}

Tronco arterioso $\quad$ Cavidade pericárdica
Bulbo arterioso
Veio venoso
Ventriculo
Átrio

\section{FASE V}
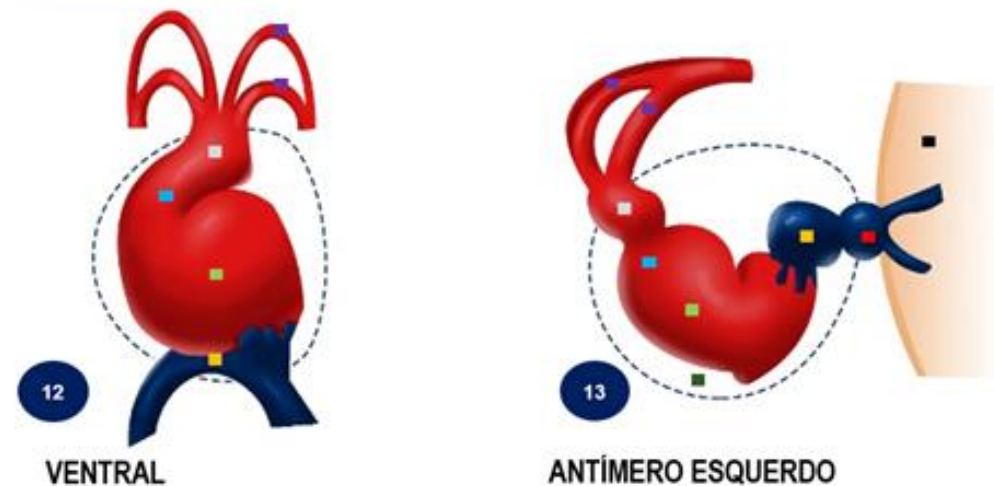

\section{ANTIMERO ESQUERDO}

Tronco Arterioso

Bulbo Arterioso

Ventriculo

Átrio

Tronco Arterioso $\square$ Cavidade Pericárdica

Bulbo Arterioso Seio Venoso

Ventriculo Septo Transverso

Átrio Arcos aórticos

Figura 31-1. Representação didática dos aspectos ventrais e esquerdos da segmentação envolvidos na formação do coração e seus estágios progressivos que ocorrem ao longo do desenvolvimento. Fonte: Hytel et. al., (2010) modificado Assunção (2020). 


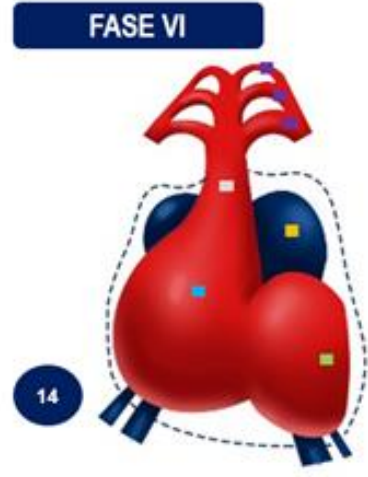

VENTRAL

Tronco Arterioso

Bulbo Arterioso

Ventriculo

Átrio

\section{FASE VII}

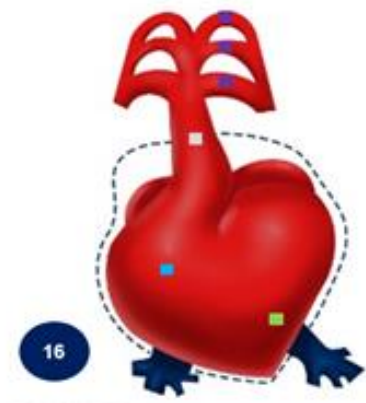

VENTRAL

Tronco Arterioso

Bulbo Arterioso

Ventriculo

Atrio

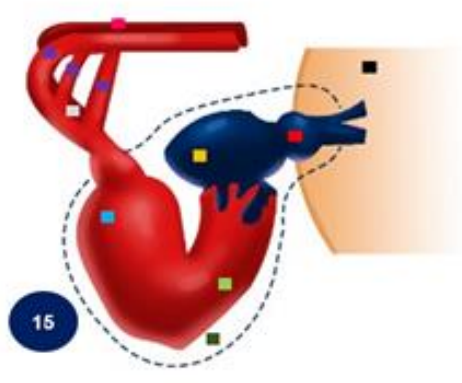

ANTIMERO ESQUERDO
Tronco Arterioso
Cavidade Pericárdica
Bulbo Arterioso
Seio Venoso
Ventriculo
Septo Transverso
Átrio
Arcos aórticos

Arcos dorsais

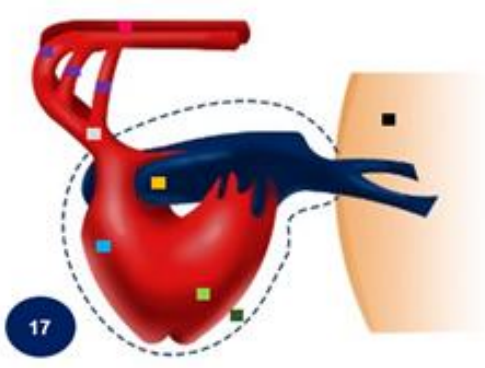

\section{ANTIMERO ESQUERDO}

$\begin{array}{ll}\text { Tronco Arterioso } & \text { Seio Venoso } \\ \text { Bulbo Arterioso } & \text { Septo Transverso } \\ \text { Ventrículo } & \text { Arcos aórticos } \\ \text { Átrio } & \text { Arcos dorsais } \\ \text { Cavidade Pericárdica } & \end{array}$

Figura 31-2. Representação didátca dos aspectos ventrais e esquerdos da segmentação envolvidos na formação do coração e seus estágios progressivos que ccorrem ao longo do desenvolvimento. Fonte: Hyttel et. al., (2010) modificado Assunção (2020). 
Em desenvolvimento, o cração é subdivido por septos complexos, entretanto, esse é um processo continuo no qual os septos se desenvolvem mesmo que diferentemente, de forma paralela. As veias associadas ao coração surgem a partir da quarta semana do desenvolvimento embrionária nos mamiferos, sendo estas responsáveis pela drenagem do coração, a saber: as veias vitelinicas - responsáveis pelo transporte do sangue desoxigenado do saco vitelinico e que se desembocam diretamente no seio venoso. Essas veias vão desde o tubo estreito vindo do intestino médio em direção ao embrião. Os remanescentes das veias vitelinicas formarão as veias hepáticas. Também provinda da comunicação de dois vasos (ou veias vitelinicas) teremos a veia porta.

As veias umbilicais são responsáveis pelo o transporte do sangue oxigenado da placenta para o seio venoso. Mediante o desenvolvimento do figado essas veias perdem sua conexão com o coração se desembocando no figado. Na porção interna do figado um ducto venoso que ligara a veia umbilical $œ m$ a veia cava caudal será formado. Já as veias cardinais transportam o sangue desoxigenado do corpo do animal, sendo o principal sistema de drenagem, drenando a parte cefálica e caudal do embrião.

As veias cardinais, em geral, apresentam duas derivações, sendo estas as veias subcardinais que formarão o tronco da veia renal, as veias adrenais e gonodais e as veias supracardinais que formará a parte da veia cava caudal, a veia cava cranial e bráquiocefálica esquerda. A veia cava caudal tem origem das mais diversas alterações provindas das veias primitivas do tronco. Tal veia é formada por quatro segmentos: um segmento hepático derivado das veias e sinusóides hepáticos, um segmento pré-renal que deriva da veia subcardinal direito, um segmento renal derivado das subcardinais com supracardinais concomitantemente e um segmento pós-renal derivada da veia supracardinal direita.

Os sacos aórticos dão origem aos arcos aórticos que suprem os arcos faringeos, e ao se fundirem forma uma única aorta. As artérias intersegmentares correm pelos segmentos do corpo difundindo sangue para estes e seus derivados tecidos. Tais artérias dão origem a artéria vertebral, artérias intercostais, artérias lombares, artérias iliacas comum e as artérias sacrais laterais. 
Neste percurso, as artérias vitelinicas seguem seu trajeto até o saco vitelinico e mais tarde para o intestino primitivo. Três são artérias vitelinicas sendo a artéria celiaca responsável por irrigar o intestino anterior, a artéria mesentérica superior irrigando o intestino médio e a artéria mesentérica inferior responsável pela irrigação do intestino posterior. Já as artérias umbilicais transformam-se em artérias iliacas internas e artérias vesicais superiores.

No que se refere as contrações ritmicas do coração primitivo, tal têm origem na porção muscular no órgão (miocárdio) presente no seio venoso, tal estimulo segue para os músculos do átrio e ventrículo. No início a circulação sanguínea no embrião é do tipo fluxo e refluxo, mas ao final da quarta semana em mamiferos, por exemplo, as contrações coordenadas do coração resultam em um fluxo do tipo unidirecional. 0 sangue venoso chega no átrio primitivo controlado pelas válvulas sinoatriais, passa pelo canal atrioventricular segue para o ventriculo primitivo, passa pelo bulbo cardiaco e pelo saco aórtico até serem distribuidos pelos árticos aórticos nos arcos faringeos e dai vai para o embrião, saco vitelinico e placenta.

No que se refere a septação do coração primitivo, esta são classificadas em: septação do canal atrioventricular que ocorrem nas paredes do canal atrioventricular possibilitando a formação dos coxins endocárdios, os mesmo se fundem e com isso se dividem em canais atrioventriculares direito e esquerdo; e septação do átrio primitivo, neste o átrio se divide em direito e esquerdo pela fusão do septum primum e o septum secundum. No centro do átrio primitivo o seio venoso sofre alterações, essas alterações faz com o que o átrio primitivo se abra em cornos direito e esquerdo, corno direito segue seu trajeto junto ao desenvolvimento e o esquerdo se transforma no seio coronário

Aderida no átrio esquerdo a veia pulmonar cresce na sua parede dorsal e se expande ao longo do desenvolvimento se ramificando com o crescimento do átrio. 0 septo intraventricular primitivo indica inicio da divisão do ventrículo primitivo. Depois do fechamento e divisão dos ventrículos a parte direita fica em comunicação com artéria tronco pulmonar e o esquerdo com a artéria aorta. As válvulas cardiacas presentes na base do coração se diferenciam anatomicamente em válvulas semilunares (estas se originam após septação do tronco arterioso) e válvula atrioventricular (são a tricúspide 
do lado direito e mitral do lado esquerdo, que se desenvolvem após a proliferação de tecidos presentes ao redor dos canais atrioventriculares.

Os derivados dos arcos aórticos são considerados por estudiosos da área em número de 6 pares, tais arcos têm a função de irrigar os arcos faringeos com origem nos sacos aórticos. O primeiro par dão origem as artérias maxilares, que supre os ouvidos, dentes, músculos dos olhos e da face, contribuindo para formação das artérias carótidas externas. $O$ segundo par responsáveis pela formação das artérias estapédicas que supre a orelha média. O terceiro formam as carótidas comum e carótidas internas, responsáveis pelo suprimento de estruturas da cabeça, ouvidos e meninge. Quarto par deriva da aorta e forma a subclávia direita. 0 quinto par não apresenta desenvolvimento de vasos que constituem o sistema de vasos. E por fim o sexto par responsáveis pela formação da artérias pulmonares direita e esquerda.

\section{Circulação fetal: considerações gerais}

As fases do desenvolvimento embrionário intrauterino que se seguem o estágio da fecundação (ou fertilização) são divididos em periodo embrionário e periodo fetal. O periodo embrionário é estabelecido como o intervalo entre a formação do embrião e o desenvolvimento dos primeiros órgãos. Em ovinos, suinos e cães, este periodo é de aproximadamente 30 dias enquanto em humanos, equinos e bovinos se estende até aproximadamente 56 dias. Após a fase embrionária inicia-se, então, o periodo fetal. O periodo fetal corresponde ao crescimento e ganho de peso do animal e à diferenciação dos seus tecidos primordiais, órgãos e sistemas, indo até o nascimento. Ao longo deste periodo, alterações anatomofisiológicas ocorrem diferindo significativamente do periodo neonatal (ou pós-parto).

$\mathrm{Na}$ fase embrionária, o coração dos mamiferos, se forma por volta do $22^{\circ}$ dia do desenvolvimento. Seus batimentos se iniciam na $22^{\circ}$ dia em suinos, na $23^{\circ}$ dia em bovinos e cães e no $24^{\circ}$ dia em equinos; nos humanos, entre o $22^{\circ}$ e $23^{\circ}$ dias; já em aves domésticas no $2^{\circ}$ dia de incubação. Na vida extrauterina, o oxigênio proveniente do ar entra pelos alvéolos pulmonares e passa para os capilares alveolares, tornando o sangue oxigenado (ou arterial). Deste modo, o sangue venoso (rico em gás 
carbônico), que provêm dos tecidos do corpo do animal, deixa o gás carbônico nos alvéolos, eliminando-o para o ar atmosférico.

Devido a intensa fase de crescimento e desenvolvimento, na vida fetal o individuo torna-se incapaz de respirar o ar do meio externo, sendo este completamente da mãe para receber o oxigênio e os nutrientes, as trocas gasosas nos pulmões nesta fase não ocorre. Os alvéolos do feto estão repletos de liquido e seus capilares estão contraidos.

A obtenção do oxigênio e dos nutrientes essenciais à vida ocorre pelo cordão umbilical, uma estrutura tubular envolta por membrana amniótica, esta contem três vasos: uma veia e duas artérias umbilicais. Tal cordão é fundamental na condução do sangue fetal em direção a placenta, mas isso não ocorre com animais que nascem de ovos. Abaixo da casca do ovo no desenvolvimento de Gallus gallus domesticus existem duas membranas finas, e no momento em que os ovos estão incubados em alta temperatura, formam uma câmara de ar (ou bolsa) no interior do ovo o que garante o desenvolvimento e circulação de forma adequada do individuo (Figura 32). A placenta é de origem materna e fetal, sendo uma estrutura complexada e que por meio dela ocorrem as trocas gasosas entre o feto e a mãe, tendo papel crucial na vida intrauterina, seu tamanho varia entre as espécies de mamiferos (Figura 33).

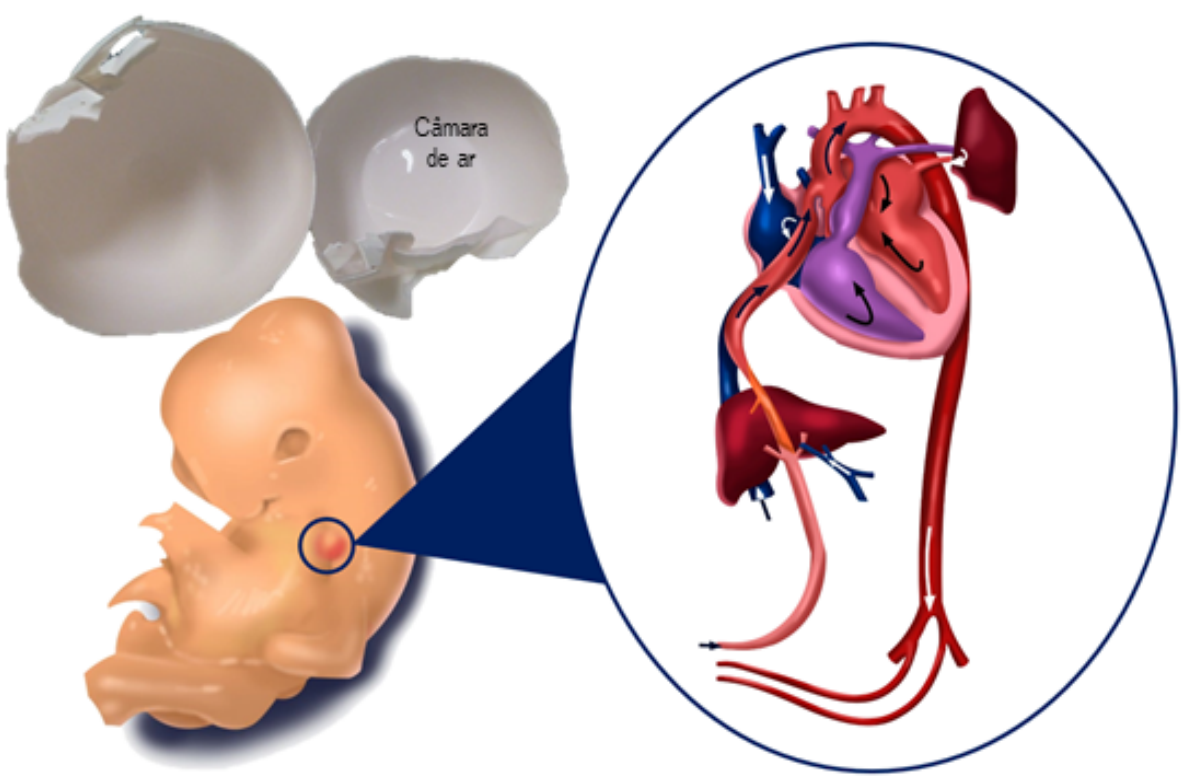

Figura 32. Representação da circulação em Gallus gallus domesticus. Fonte: Assunção (2020). 


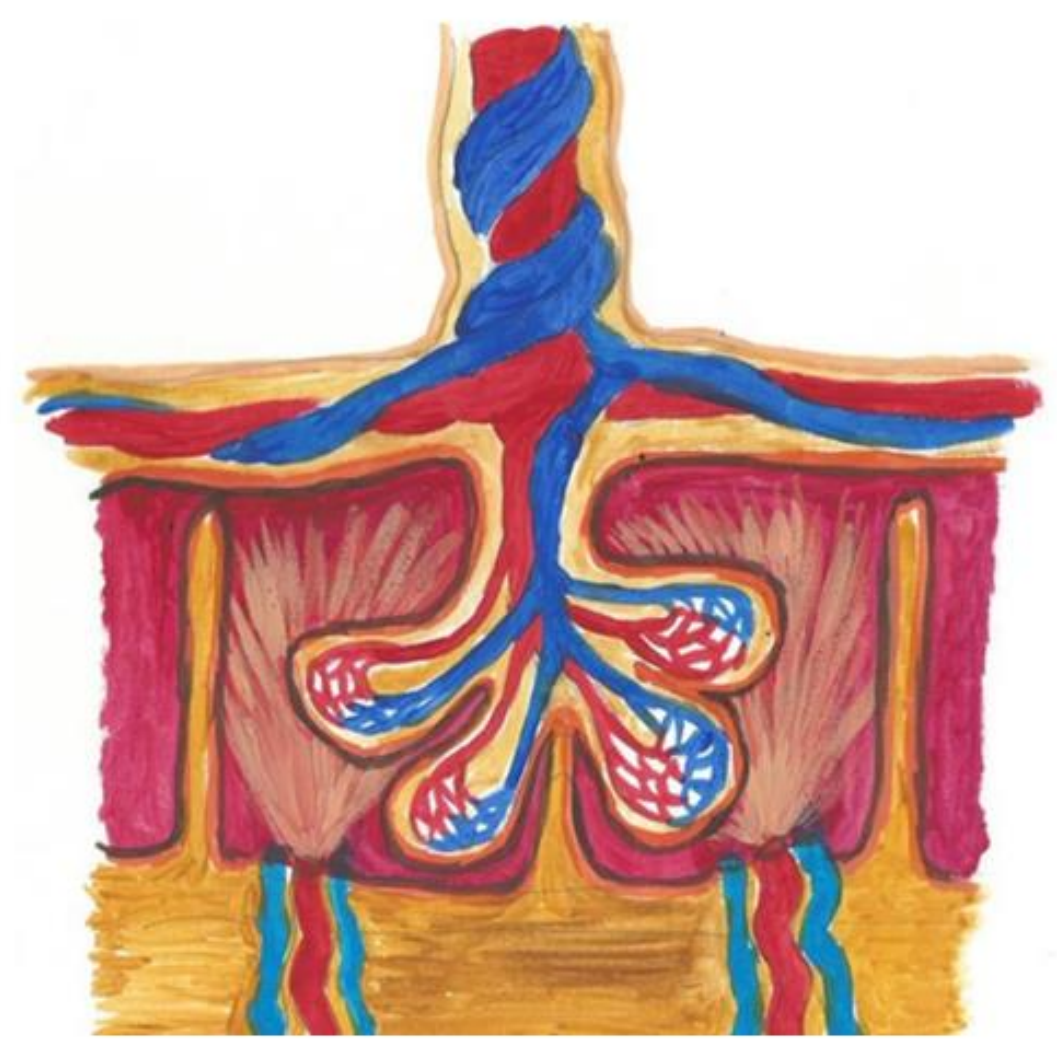

Figura 33. Esquema das trocas sanguineas materno-fetais. Fonte: Hytel et. al., (2010) modificado Silva (2019).

Na vida pós-natal, sendo mesmo acelerado do que o pré-natal, não há comunicação direta entre os átrios, mas, no feto, o forame oval permite que o sangue "misto" passe diretamente do átrio direito para o esquerdo. Fato este que reduz o fluxo sanguineo na circulação pulmonar (ventriculo direito, artérias pulmonares, capilares alveolares e veias pulmonares) (Figura 34).

Do átrio esquerdo o sangue "misto" passa para o ventriculo esquerdo, para a aorta e é bombeado para todos os tecidos do como do animal. O forame oval se fecha logo após o nascimento. O ducto arterioso é responsável pela comunicação do tronœ pulmonar com o arco aórtico, de forma que o sangue advindo do ventriculo direito passe do tronco pulmonar e da aorta evitando a circulação pulmonar. Este canal também se fecha logo após o nascimento, formando o ligamento arterioso.

Nesse interim, o sangue misto entra na aorta (lembrando que ainda assim parte dele passa pelos capilares pulmonares, veias pulmonares, átrio esquerdo e 
ventriculo esquerdo) e se distribui pelo corpo do animal. A aorta se bifurca em artérias iliacas comuns, que por sua vez se dividem em artérias iliacas internas e externas Das artérias iliacas internas originam-se duas artérias umbilicais, que conduzem o sangue misto para a placenta (porém com nivel ainda mais baixo de oxigênio, cerca de $58 \%$ de saturação). A veia umbilical, as artérias umbilicais e o ducto venoso se fecham após o nascimento e após o corte (ou fechamento) do cordão umbilical, o que por fim origina o ligamento venoso do figado (ducto venoso), ligamento redondo do figado (veia umbilical) e aos ligamentos umbilicais mediais (artérias umbilicais).

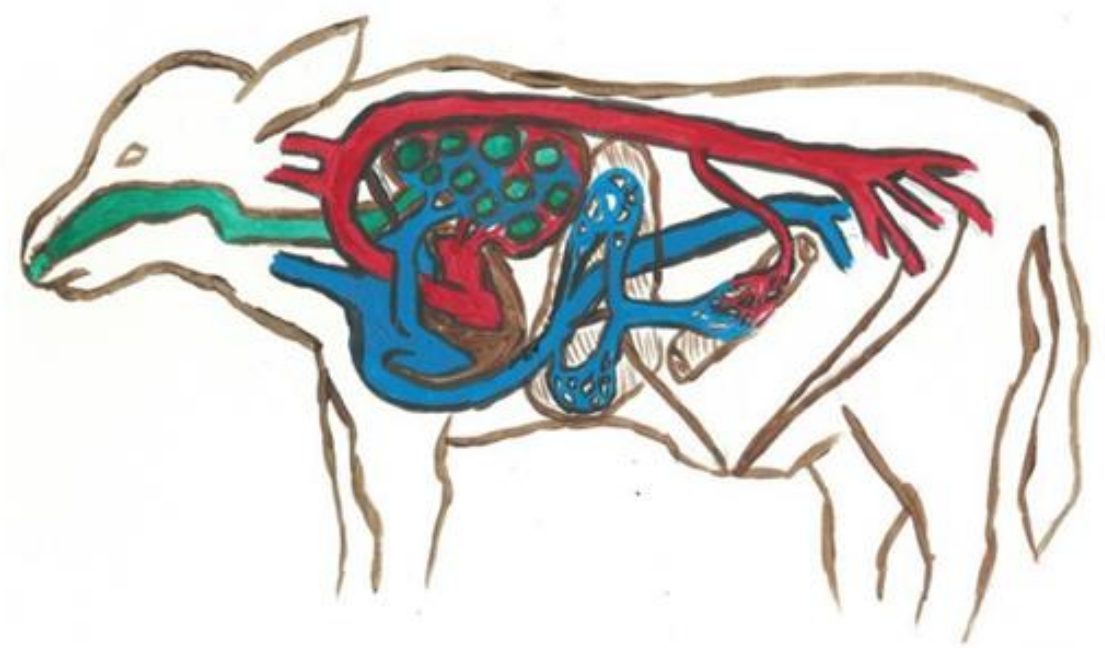

Figura 34. Representação da circulação pós-natal em Bos taurus. Fonte: Hytel et. al., (2010) modificado Silva (2019).

\section{Evolução do coração em aves e mamíferos}

Os mamiferos e as aves domésticas, apresentam um septo interventricular que divide os ventriculos em direita e esquerda. A circulação destes animais é completamente dupla, apresentando um circuito pulmonar de baixa pressão (lado direito) e um circuito sistêmico de alta pressão (lado esquerdo). No direito tal órgão reúne o sangue desoxigenado dos tecidos sistêmicos bombeando para o circuito pulmonar. No esquerdo, o sangue oxigenado é bombeado dos pulmões para o circuito sistêmico. Nas aves o coração é grande tendo alta velocidade de fluxo sanguineo Nesse grupo o seio venoso é vestigial. O cone arterioso (ou bulbo cardiaco) é apenas uma câmara embrionária considerada transitória. 


\section{Atividades}

a) Descreva de forma sucinta os eventos que antecedem o desenvolvimento do sistema cardiovascular.

b) Defina com suas palavras os periodos do desenvolvimento pré e pós-natal.

c) Na vida fetal, o individuo consegue obter o oxigênio (e os nutrientes) essenciais à vida de forma eficiente de qual maneira?

d) Nos mamiferos, o coração se forma a partir de qual semana da gestação.

e) Defina o fluxo sanguineo do tipo unidirecional e qual das espécies animais tal fluxo ocorre.

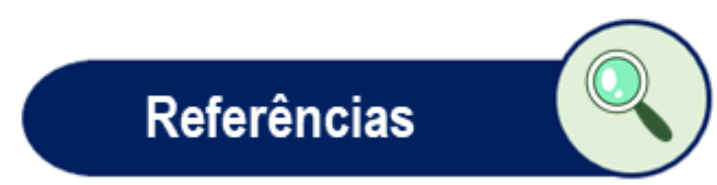

BERGWERFF, M.; DERUITER, M. C.; GROOT, A. C. G. Comparative anatomy and ontogeny of the ductus arteriosus, a vascular outsider. Anatomy and Embryology, v. 200 , p. 559-571, 1999.

CARABELLO, B. A. Evolution of the study of left ventricular function: everything old is new again. Circulation, v. 11, n. 105, p. 1602-1608, 2002

COCHARD, Larry R.. Atlas de Embriologia Humana de Netter. São Paulo; Artmed. 2003. p. 236-245.

HYTTEL, P.; SINOWATZ, F. \& VEJSTED, M. Domestic Animal Embryology. 11th ed. Saunders, Elsevier, p.359. 2010.

LANGMAN, Jan. Embriologia Médica. São Paulo; Atheneu editora São Paulo S.A.1969. p.154-162.

MASSARI, C. H. A. L.; MIGLINO, M. A. Anatomia cardíaca aplicada à medicina veterinária [recurso eletrônico]. In: SILVA, A. F et al. São Paulo: Faculdade de Medicina Veterinária e Zootecnia. Universidade de São Paulo, 2019. 


\section{Dados dos Autores}

Marcos Paulo Batista de Assunção: licenciou-se em Ciências Biológicas (2018) pela Unidade Acadêmica Especial de Biotecnologia da Universidade Federal de Goiás Regional Catalão, é atualmente doutorando em Ciências pelo Programa de PósGraduação em Anatomia dos Animais Domésticos e Silvestres do Departamento de Cirurgia da Faculdade de Medicina Veterinária e Zootecnia da Universidade de São Paulo FMVZ/USP. Participou do Subprojeto de Biologia e no Subprojeto Interdisciplinar de Iniciação à Docência (CAPES) - (2016-2018). Possui experiência com Anatomia Comparativa de Animais Silvestres: Mamiferos do Cerrado com ênfase à Anatomia Descritiva da Artéria Aorta Abdominal e seus Ramos em Quati (Nasua nasua). Tem experiência nas áreas de Anatomia comparativa e descritiva, ensino da embriologia comparativa com ênfase ao Sistema Cardiovascular e também na produção de material didático instrucional como método alternativo para o ensino.

Maria Angélica Miglino: Professora titular do Departamento de Cirurgia da FMVZ USP e vice-coordenadora do Programa de Pós-graduação em Anatomia dos Animais Domésticos e Silvestres. Doutorou-se em 1985 pelo PPG Anatomia Funcional: Estrutura e Ultraestrutura ICB/USP. Integrou o Comitê de Área da Fapesp e do CNPq, além de ter exercido as funções de Viœe-Coordenadora e Coordenadora de Área (Medicina Veterinária) da Capes. É membro da Real Academia de Ciências Veterinárias da Espanha. Sócia da Sociedade Brasileira de Anatomia, World Association of Veterinary Anatomists, e da American Society of Anatomy. Recebeu prêmios (Loke Award for Early Care Researchers, IFPA; The EPG Peter Kaufmann New Ivestigator Award; Prêmio Capes de Tese) e homenagens. É pesquisadora principal do INCT (Instituto Nacional de C\&T em Células-tronco e Terapia Celular no Câncer). Colaboradora do CEPID, Thecnology Transfer Project e Centro de Terapia Celular. Atua na área de Medicina Veterinária, Ciências Morfológicas, Biologia do Desenvolvimento com ênfase à Placenta e Placentação, Terapia Celular em Modelos Animais, e Engenharia Tecidual, desenvolvendo projetos tecnológicos multidisciplinares voltados à regeneração de órgãos e de tecidos. 


\section{Notas importantes}

1) Os autores ressaltam que toda a bibliografia consultada foi criteriosamente informada. Cabe destacar que as imagens, em que a indicação de autoria não foi informada, foram produzidas pela equipe deste trabalho, tratando-se, portanto, de material próprio e original.

2) As opiniōes, hipóteses e conclusões/recomendações expressas neste material são de responsabilidade dos autores.

3) É permitido exibir, traduzir, executar o conteúdo e ainda criar obras derivadas, sob as condições a seguir: Deve-se dar crédito ao autor original do conteúdo ou figura, da forma especificada pelo autor ou licenciante. Proibido utilizar o conteúdo com finalidade extra comerciais. Para cada novo uso ou distribuição, deve-se deixar claro as licenças de uso desta obra. 


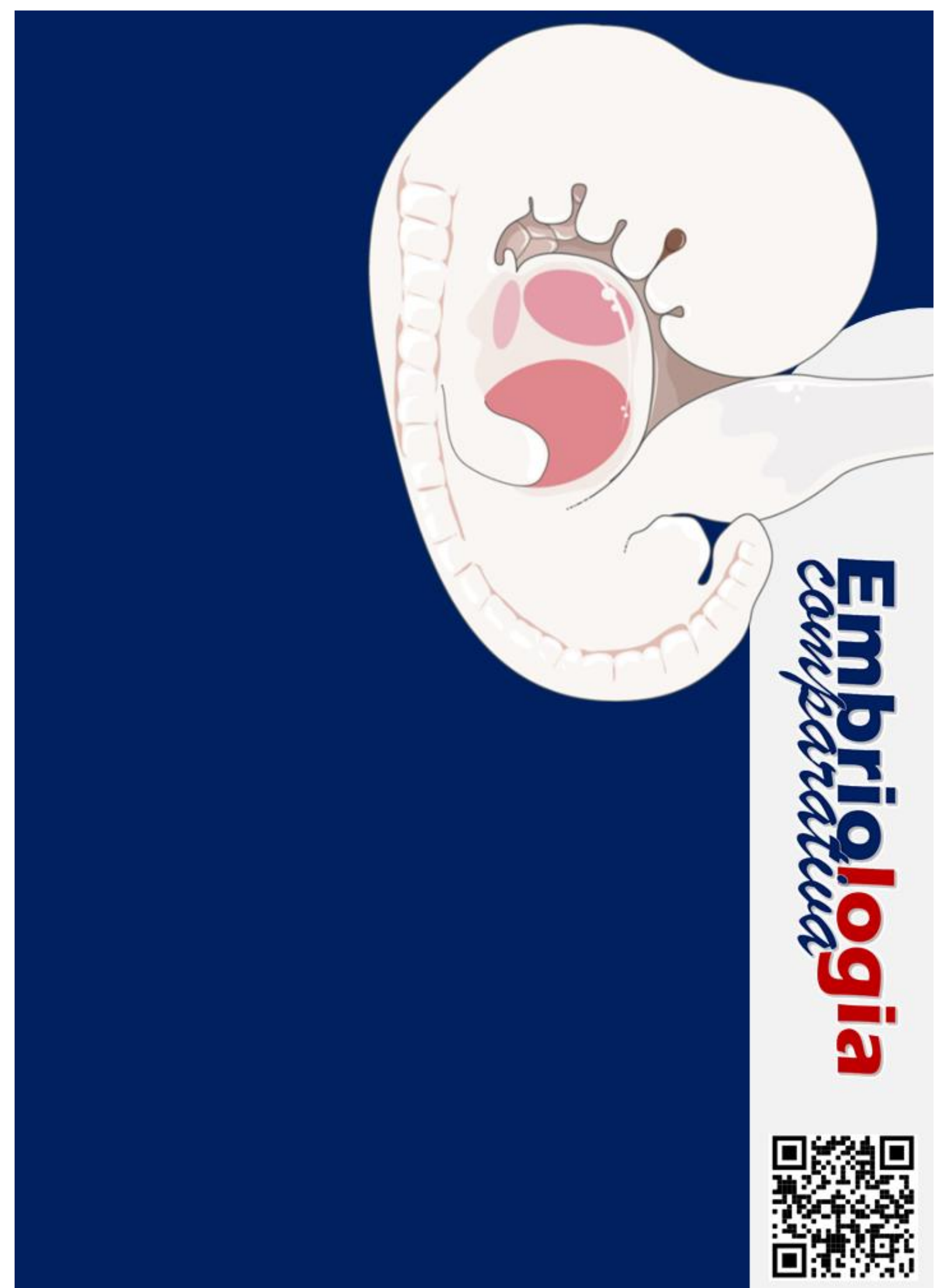


APÊNDICE C - Videoaulas
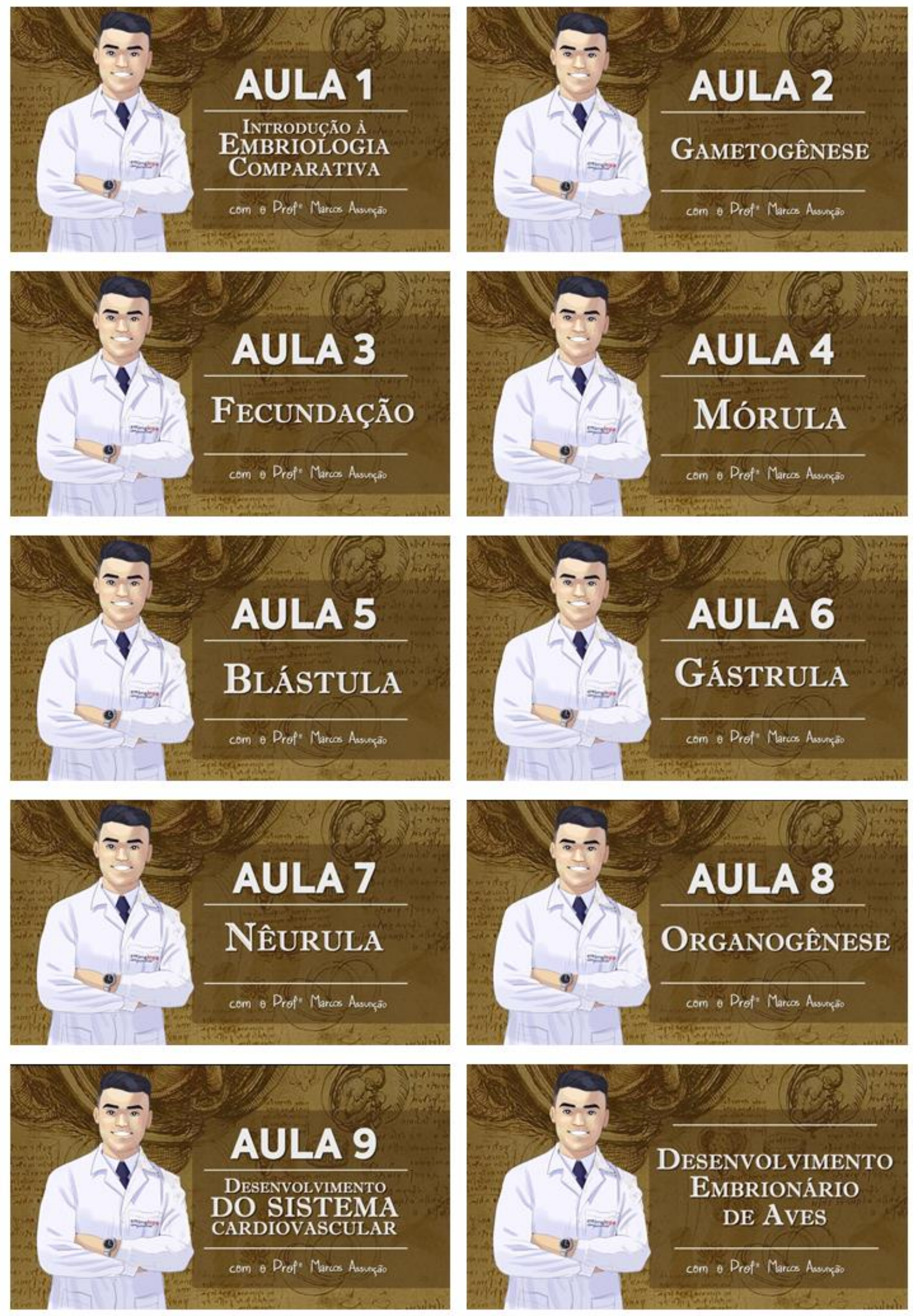
APÊNDICE D - Podcasts
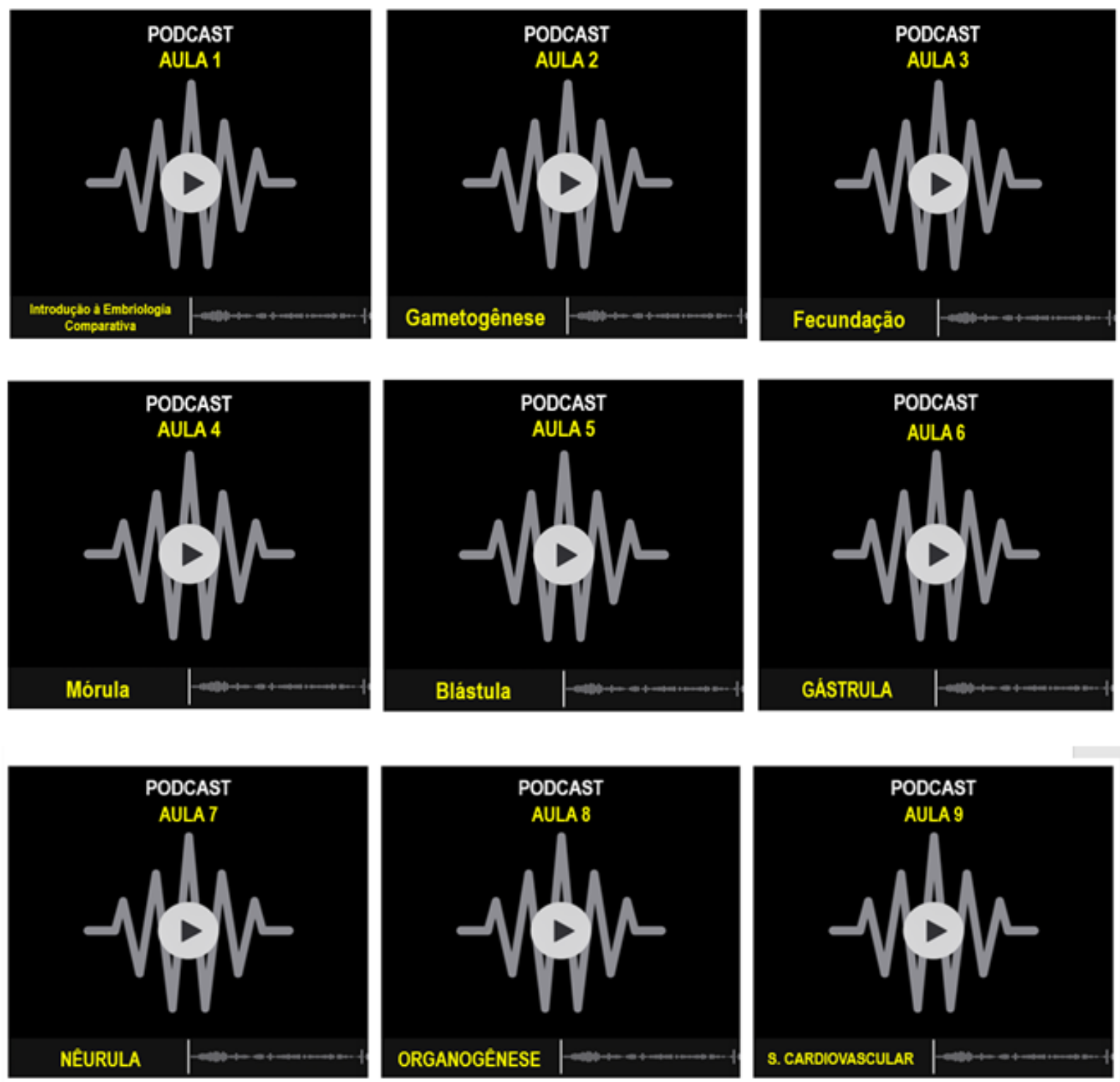
APÊNDICE E - Atlas macroscópico "Embriologia veterinária"

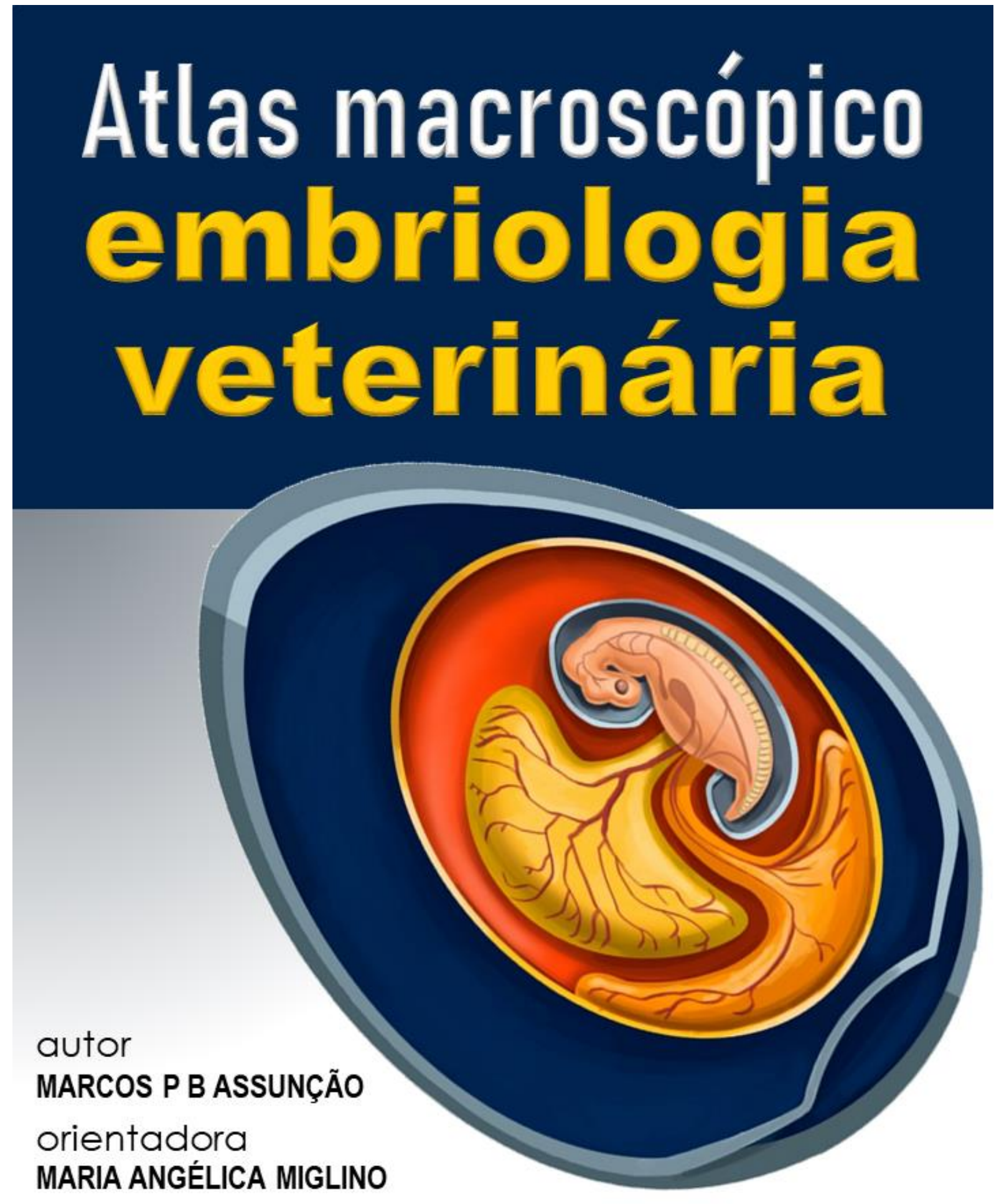

\section{DESENVOLVIMENTO EMBRIONÁRIO DE AVES}

(Gallus gallus domesticus) 
Atlas

macroscópico

embriologia

veterinária

Desenvolvimento embrionário

de aves (Gallus gallus domesticus)

Foco no Sistema Cardiovascular

\section{MARCOS PAULO BATISTA DE ASSUNÇÃO \\ BiólogoUFG \\ Doutorando FMVZ-USP \\ PG Anatomia dos Animais Domésticos e Silvestres}
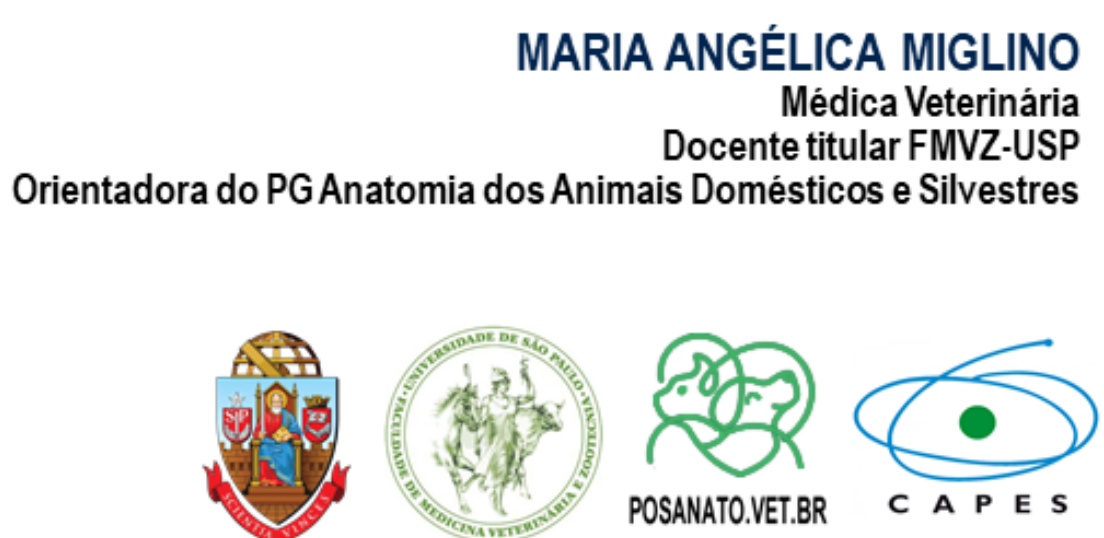

POSANATO.VET.BR 


\section{Prefácio}

Este atlas figurativo é destinado aos estudantes dos cursos de Medicina Veterinária, Ciências Biológicas e áreas afins, na perspectiva de auxiliar os alunos durante o processo de ensino-aprendizagem da Embriologia Comparativa. As caracteristicas macroscópicas da espécie ao longo do desenvolvimento embrionário e fetal são apresentadas por meio da transposição didática realizada, a partir das fotodocumentações reais dos espécimes após o momento da coleta. As estruturas foram identificadas em legendas valendo-se de indicações que acompanharam as fotografias. A nomenclatura utilizada foi baseada na segunda edição (2017) da Nomina Embryologica Veterinaria (N.E.V). Informações complementares foram adicionadas no rodapé da página de cada Figura quando necessário, para auxiliar na interpretação das imagens. Cada seção apresenta fotografias das caracteristicas morfológicas supericiais de cada idade do desenvolvimento. Todas as fotografias e ilustrações foram preparadas especialmente para este trabalho.

Os espécimes que aparecem neste trabalho, são embriões de galinha (Gallus gallus domesticus) de diferentes idades (1 a 21 dias). Os cadáveres foram coletados e fixados utilizando os métodos de rotina do Laboratório de Anatomia, Histologia e Embriologia do Departamento de Cirurgia da Faculdade de Medicina Veterinária e Zootecnia da Universidade de São Paulo (FMVZ-USP).

$\mathrm{O}$ objetivo das imagens ilustrativas foi destacar as estruturas morfológicas do animal e que podem variar ao longo do desenvolvimento embrionário, apresentando aos estudantes imagens e descrições semelhantes às que ocorrem no animal in vivo, na perspectiva de reduzir o número de animais utilizados na prática laboratorial. Os animais foram apresentados em vista lateral esquerda para que fosse visualizada a proeminência cardiaca. A ideia foi proporcionar uma visão da dinâmica relativa aos conteúdos teóricos e práticos do desenvolvimento da espécie. 


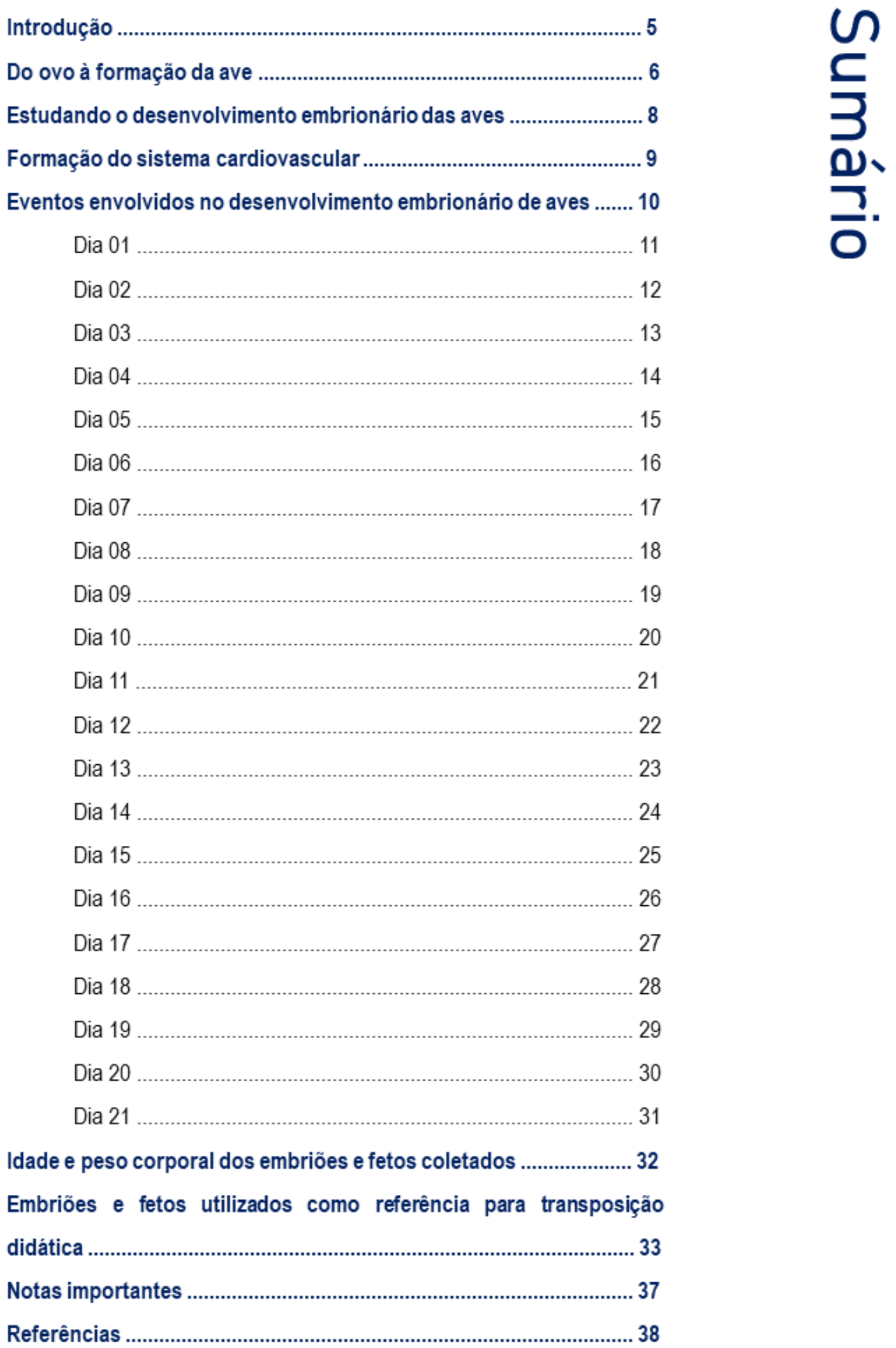




\section{Introdução}

Estudos acerca das ciências morfológicas sempre em constante expansão, necessitam de recursos didáticos disponiveis, os quais ainda escassos, determinam como consequência a redução do tempo dedicado à determinados assuntos, œmo a embriologia. Diversas instituições carecem de material biológico adequado para a necessária abordagem do conteúdo desta disciplina, e a solução óbvia para esse problema é utilizar cada vez mais recursos didáticos como métodos alternativos para complementar a demanda da carga horária exigida.

A Embriologia, especialidade das Ciências Biológicas voltada para o estudo dos organismos durante o estágio embrionário, caracteriza cada processo inserido na formação do individuo. Engloba os estágios da gametogênese, fecundação, clivagem, gastrulação, neurulação e organogênese, demonstrando mediante diferenças significativas de uma espécie para outra, os aspectos macroscópicos do desenvolvimento embrionário. Nas aves (Gallus gallus domesticus) é possivel observar caracteristicas morfológicas, por exemplo, envolvidas em parte ou no todo do desenvolvimento, ou seja, dia após dia até seu nascimento.

A sequência de imagens incluidas neste trabalho representa cada fase do desenvolvimento da galinha, as quais foram fotografadas e submetidas a transposição didática, afim de suprir a falta de material biológico disponivel para aulas teóricopráticas, permitindo assim reduzir o número de animais utilizados em experimentações. A ideia foi compensar a demanda de material, expondo uma sequência de imagens em alto relevo, com o máximo de detalhes envolvidos no decorrer do desenvolvimento considerado normal. Soma-se a isto, apresentar a progressão das caracteristicas morfológicas necessárias à medida que elas ocorrem.

$\mathrm{O}$ animal em desenvolvimento foi demonstrado por fotografias da vista lateral esquerda, apresentando a proeminência cardiaca. Face ao exposto, estudantes e profissionais poderão avaliar e explorar cada estrutura, de maneira a diagnosticar o desenvolvimento normal e eventualmente as má formações quando presente. 


\section{Do ovo à formação da ave}

As aves (Gallus gallus domesticus) se desenvolvem e eclodem no periodo compreendido entre 20 a 21 dias (para o desenvolvimento deste material didático o periodo de eclosão foi de 21 dias). Naquilo que se refere aos seus constituintes morfofuncionais, estes tem sido cada vez mais utilizados em estudos embriológicos. Historicamente, o desenvolvimento embrionário de aves domésticas foi um dos primeiros a ser estudado; foi Aristóteles (384 a.C.-322 a.C.) quem fez sua mais importante descoberta, pois, segundo o filósofo grego, o desenvolvimento dos órgãos ocorre de forma gradual. Os mais diversos relatos encontrados na literatura são unânimes em considerar o embrião da galinha como um dos recursos prontamente disponiveis, de fácil incubação, além de demonstrar facilidade de observação do desenvolvimento embrionário, a partir de uma pequena abertura em forma de janela na casca do ovo (caracteristica dos oviparos).

No processo de fecundação, os ovos são fáceis de serem mantidos em incubadoras (os ovos para este trabalho, foram encubados à $47^{\circ} \mathrm{C}$ ). Durante os primeiros estágios do desenvolvimento, o embrião flutua no vitelo (ou gema) que está sendo usada para nutrição. Conforme o embrião cresce, o vitelo passa a cobrir o mesmo.

De forma mais detalhada, o óvulo após ter sido liberado do ovário da galinha é captado pelo infundibulo onde nas suas dobras encontra-se o esperma do macho. Feito a coleta do óvulo pelo infundibulo, diversos espermatozoides entram em contato com o disco germinativo, mas apenas um se une ao germe. A fecundação (ou fertilização) de fato, ocorre no periodo de 24 horas que antecede a postura do ovo, a partir dai determinadas fases do desenvolvimento do embrião ocorrem.

No periodo de 3 horas após o processo de fecundação, a célula ovo recémformada passa pela fase de clivagem (ou segmentação), ela se divide e produz duas células, e então em quatro, oito, dezesseis e assim sucessivamente. A divisão œlular continua até que as células estejam agrupadas em um pequeno ponto esbranquiçado visivel na superficie superior do vitelo.

Além dos eventos que ocorrem durante a incubação, outros eventos advindos 
deste processo ocorrem, a saber: respiração, excreção, nutrição e proteção. As

membranas extraembrionárias (saco vitelínico, âmnio, córion e alantoide) envolvidas no desenvolvimento são as membranas externas ao compo do embrião, são elas que possibilitam funções como o suprimento dos vasos sanguineos.

Tratando-se da especificidade de cada uma das membranas extraembrionárias, em sua estrutura o saco vitelinico é extremamente vascularizado constituido por uma camada de tecido que cresce sobre a superficie do vitelo, sendo esta responsável pela digestão e absorção de proteinas e lipideos. Já o âmnio é um saco translúcido preenchido por um líquido incolor embriologicamente denominado de liquido amniótico; é o âmnio e o liquido amniótico que fornecem proteção ao embrião contra choques mecânicos e possibilita o exercicio do individuo ao longo do desenvolvimento.

O alantoide possibilita a respiração do embrião. Os vasos sanguineos presentes no alantoide levam oxigênio ao embrião e, com isso, retiram o dióxido de carbono. Para além disso, o alantoide é responsável pelo o armazenamento de excreções, ou seja, absorve o albume utilizado como fonte de alimento para o embrião e absorve o cálcio da casca do ovo para fortalecimento estrutural do mesmo. Assim, o alantoide perde sua funcionalidade no momento em que $o$ individuo perfura a célula da câmara de ar e começa a respirar por conta própria. Já o córion considerada como uma quarta membrana presente no desenvolvimento embrionário tanto da galinha quanto de outras espécies domésticas, envolve o âmnio e também o saco vitelinico. Aparentemente, o córion não apresenta uma função em especifico, mais tarde o alantoide entra no processo de fusão com ele para formação da membrana córionalantoide. Portanto, vale ressaltar que as membranas extraembrionárias envolvidas no decorrer do desenvolvimento se tornam parte do individuo após o processo de eclosão. 
Como posso estudar o desenvolvimento embrionário da galinha? Uma das práticas mais utilizadas no estudo do desenvolvimento embriônico da galinha é a observação e caracterização da morfologia externa dos embriões, esta pode ocorrer de forma que o estudante ou pesquisador acompanhe parte ou o todo dos estágios envolvidos no desenvolvimento.

Entre os $2^{\circ}$ ou $3^{\circ}$ dias de incubação, é possivel, ao abrir cuidadosamente o ovo, estudar por observação, muitos dos eventos envolvidos nas fases embrionárias iniciais. Para estudos mais avançados acerca do desenvolvimento inicial, torna-se necessário a utilização de diferentes recursos microsćpicos. O uso da microscopia exige um pouco mais de tempo, além de um treinamento prévio, por parte dos estudantes recém ingressos.

Estudos acerca da formação e crescimento ósseo podem ser realizados œm técnicas especificas de coloração do embrião, como por exemplo a partir da técnica de Alizarina reconhecida por Graebe \& Liebermann, em 1868. A técnica requer tempo e materiais consideráveis, bem como gastos financeiros.

Caso o estudante ou pesquisador planeje estudar os diferentes estágios envolvidos ao longo do desenvolvimento embrionário por um ou mais dos métodos descritos acima, é necessário que se certifique de incubar ovos fecundados suficientes para esse fim. Os estágios que compreendem todo o desenvolvimento embrionário da espécie em questão, estão apresentados em imagens e descrições ultra estruturais contidas neste atlas. Parte de estruturas que correspondem ao desenvolvimento não são passiveis de serem observadas a olho nu, mas mesmo macroscopicamente ao abrir e observar um ovo a cada dia do desenvolvimento, é possivel identificar muitos dos estágios do mesmo pela observação da morfologia do embrião. 


\section{Formação do sistema cardiovascular}

O desenvolvimento do coração e do sistema vascular é frequentemente denominado em conjunto como sistema cardiovascular. $O$ cração é o primeiro órgão funcional a se formar no embrião. $O$ desenvolvimento do órgão considerado oco e propulsor de sangue, inicia-se muito cedo no mesoderma embrionário, tanto internamente (ou embrionário) quanto externamente (ou extra embrionário, saco vitelinico e placentário) ao embrião.

Uma rede vascular ocorre em diversas partes das estruturas embrionárias, mas o mais óbvio é o coração em formação muito precoce, crescendo muito rapidamente, criando uma "base" cardiaca embrionária

inicial. O sistema cardiovascular é extensivamente remodelado ao longo do desenvolvimento. Em termos especificos, o coração se forma inicialmente a partir do disco embrionário, como um simples tubo emparelhado, visivel a olho nu no $2^{\circ}$ dia do desenvolvimento.

No decorrer do tempo, pequenas regiões se diferenciam em "ilhas sanguineas ${ }^{a}$ no mesoderma embrionário, as quais contribuem com vasos sanguineos (paredes) e glóbulos vermelhos fetais. Essas "ilhas" se conectam para formar os primeiros vasos que se conectam com o tubo cardiaco. Então, o embrião cresce e se desenvolve muito rapidamente. No sétimo dia o coração está completamente formado; ocorre o dobramento do disco, transportando o órgão para a posição anatômica correta na cavidade toracoabdominal. 
Antes da postura dos ovos, ocorre o processo de divisão próprio da fecundação, além do crescimento das células vivas. A partir dai é verificado, a segregação de células em grupos para posterior formação dos tecidos primordiais. Entre a postura e a incubação, o embrião não sofre nenhum crescimento, e, o estágio da vida embrionária ainda é inativa.

Para tanto, durante a incubação é possivel observar cada evento que ocorre ao longo do desenvolvimento. Estes estão apresentados por meio de imagens macroscópicas, bem como em forma de descrição como se segue: 


\section{Início do desenvolvimento dos tecidos primordiais}

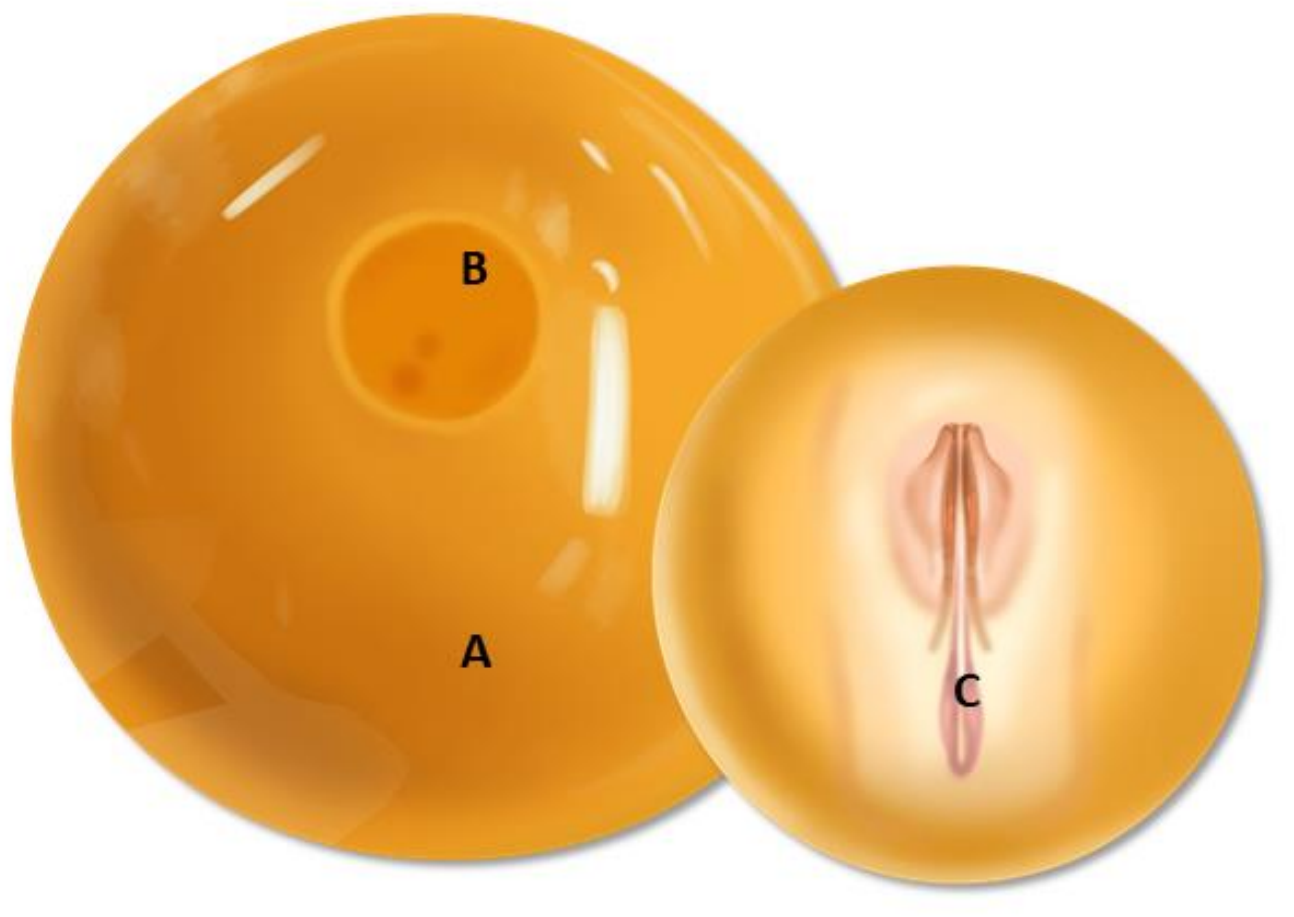

16 horas - Primeiro sinal de semelhança com um embrião 18 horas - Surgimento do trato alimentar 20 horas - Surgimento da coluna vertebral 21 horas - Inicio da formação do sistema nervoso 22 horas - Inicio da formação da cabeça 23 horas - Surgimento de "ilhas" de sangue - circulação vitelinica 24 horas - Inicio da formação do olho
A) Vitelo (ou gema)
B) Disco Germinativo
C) Embrião

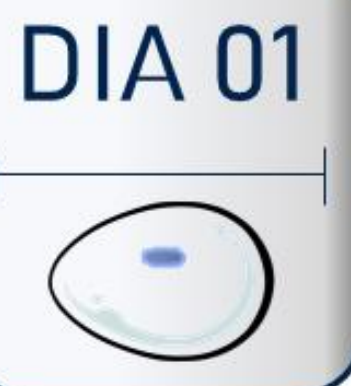





23 horas - Inicio da formação do coração 35 horas - Inicio da formação da orelha 42 horas - Inicio da função cardiaca
A) Vitelo (ou gema)
B) Disco Germinativo
C) Coração 


\section{Desenvolvimento dos vasos sanguíneos}

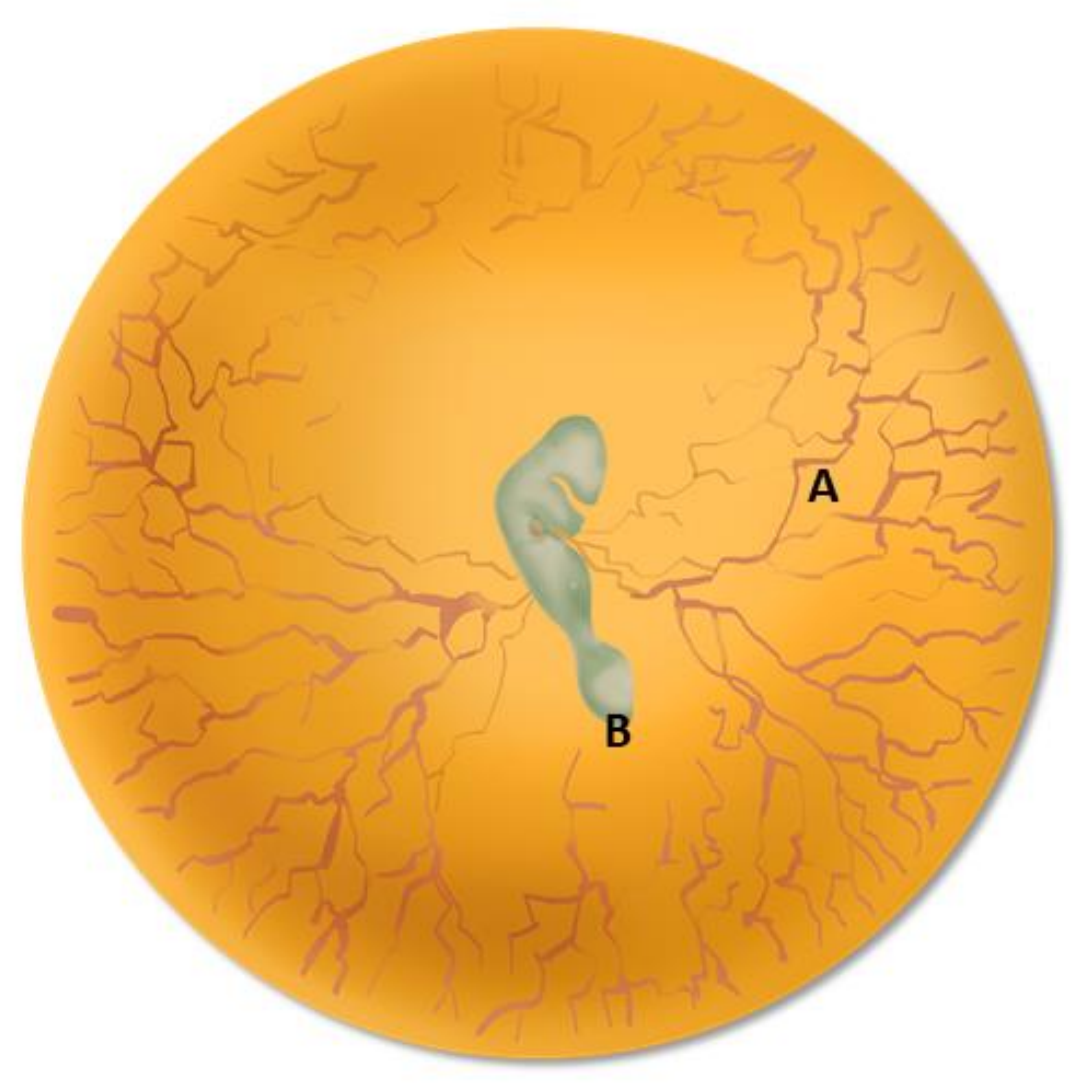

50 horas - Inicio da formação do âmnio

60 horas - Inicio da formação das narinas

64 horas - Evidências do brotamento do membro torácico (ou asas)

70 horas - Inicio da formação do alantoide
A) Vasos sanguineos
B) Broto da cauda 


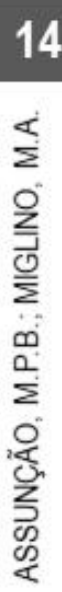

Desenvolvimento da língua

A

B

DIA 04

A) Curvatura cervical

B) Proeminência cardiaca 
Início do desenvolvimento dos órgãos reprodutivos; Diferenciação sexual e formação dos membros

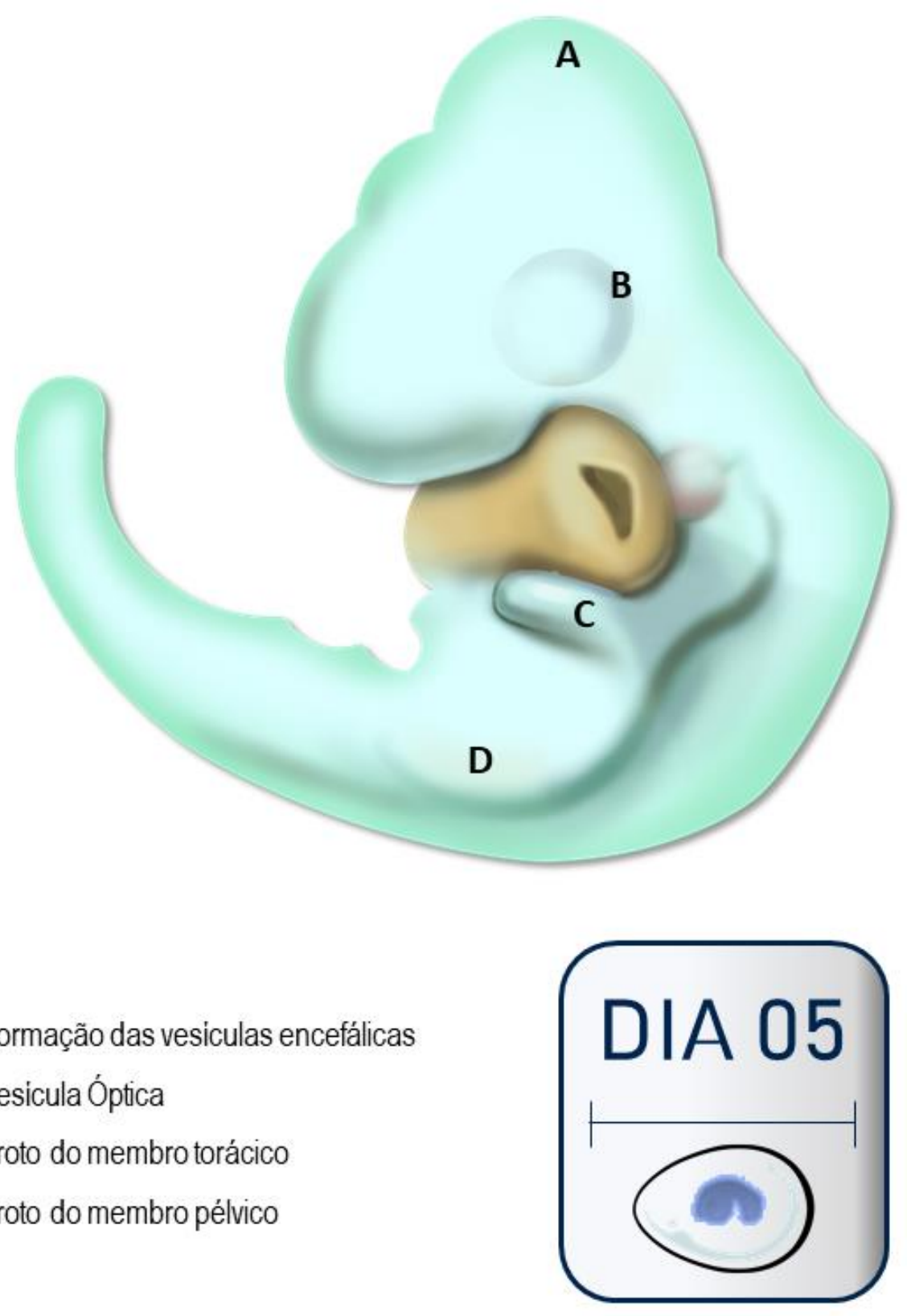
A) Formação das vesiculas encefálicas
B) Vesicula Óptica
C) Broto do membro torácico
D) Broto do membro pélvico 
Desenvolvimento dos anexos de natureza córnea: formação da ranfoteca (ou bico)
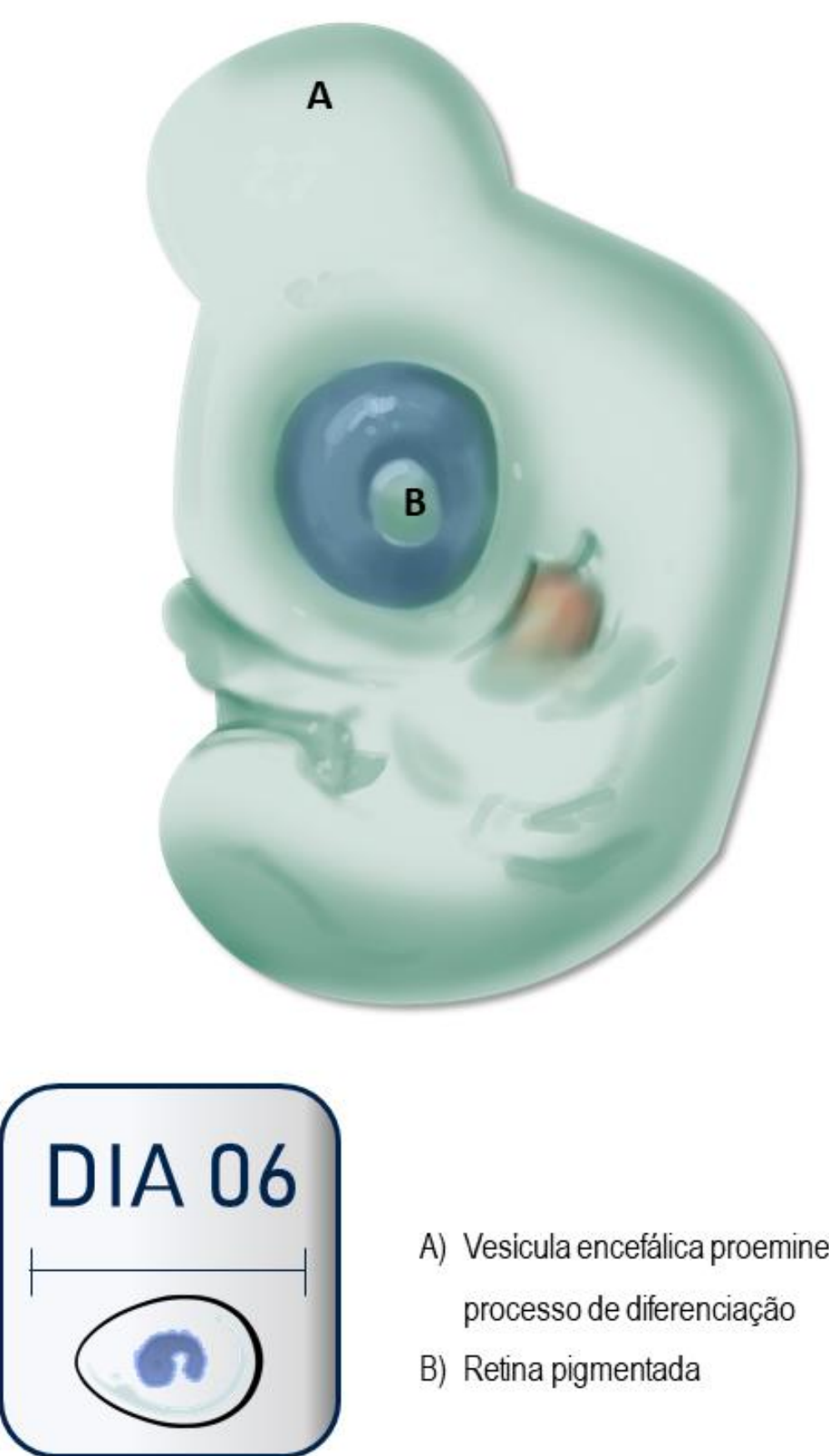

A) Vesicula encefálica proeminente e em processo de diferenciação

B) Retina pigmentada 
Desenvolvimento dos dígitos

DIA 07

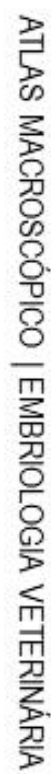

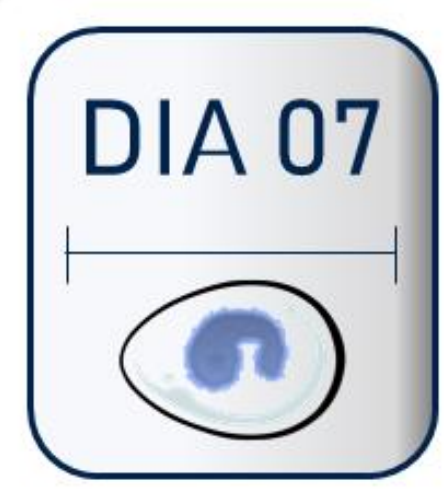




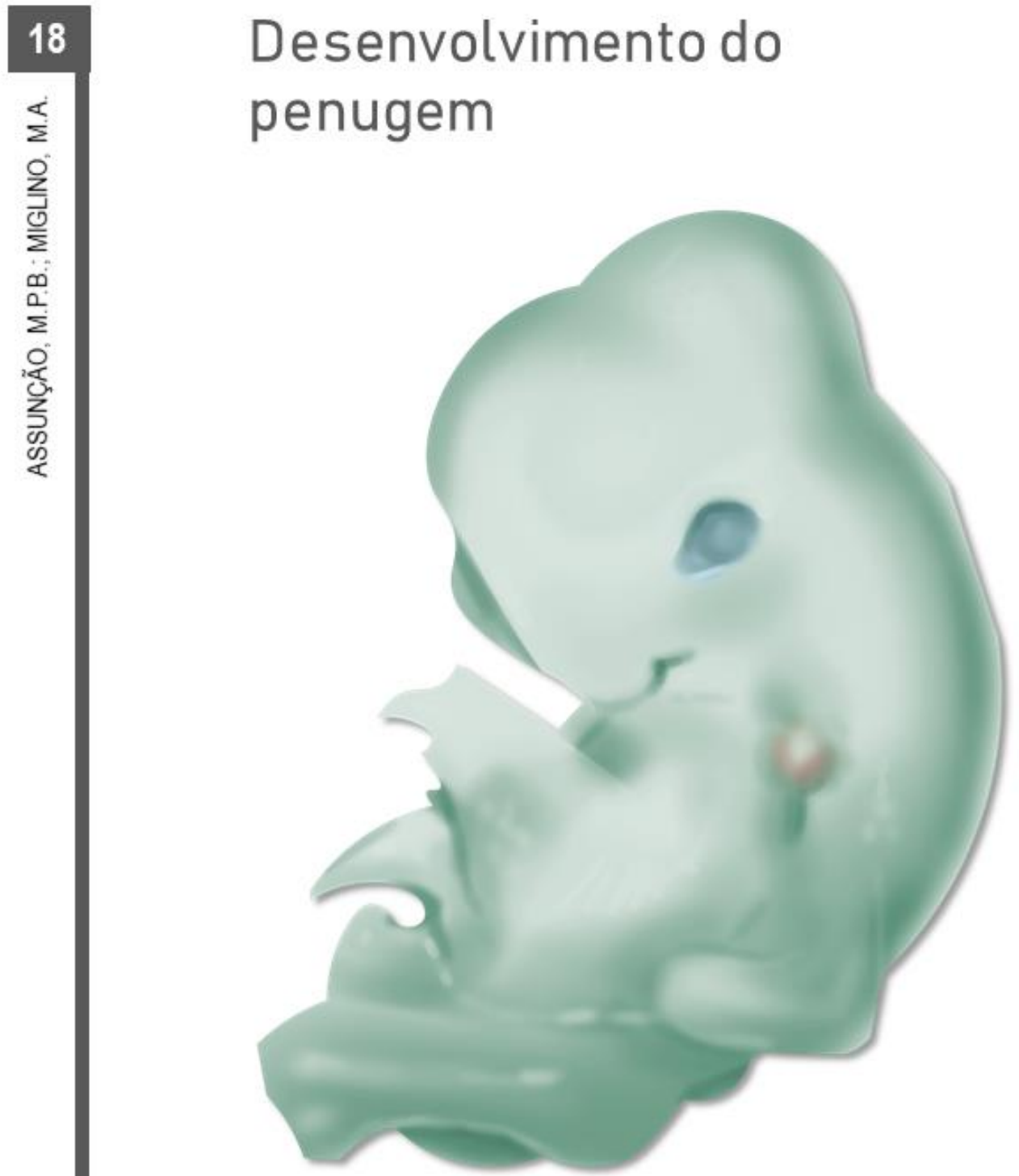

DIA 08

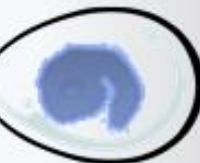


Desenvolvimento da abertura da cavidade bucal

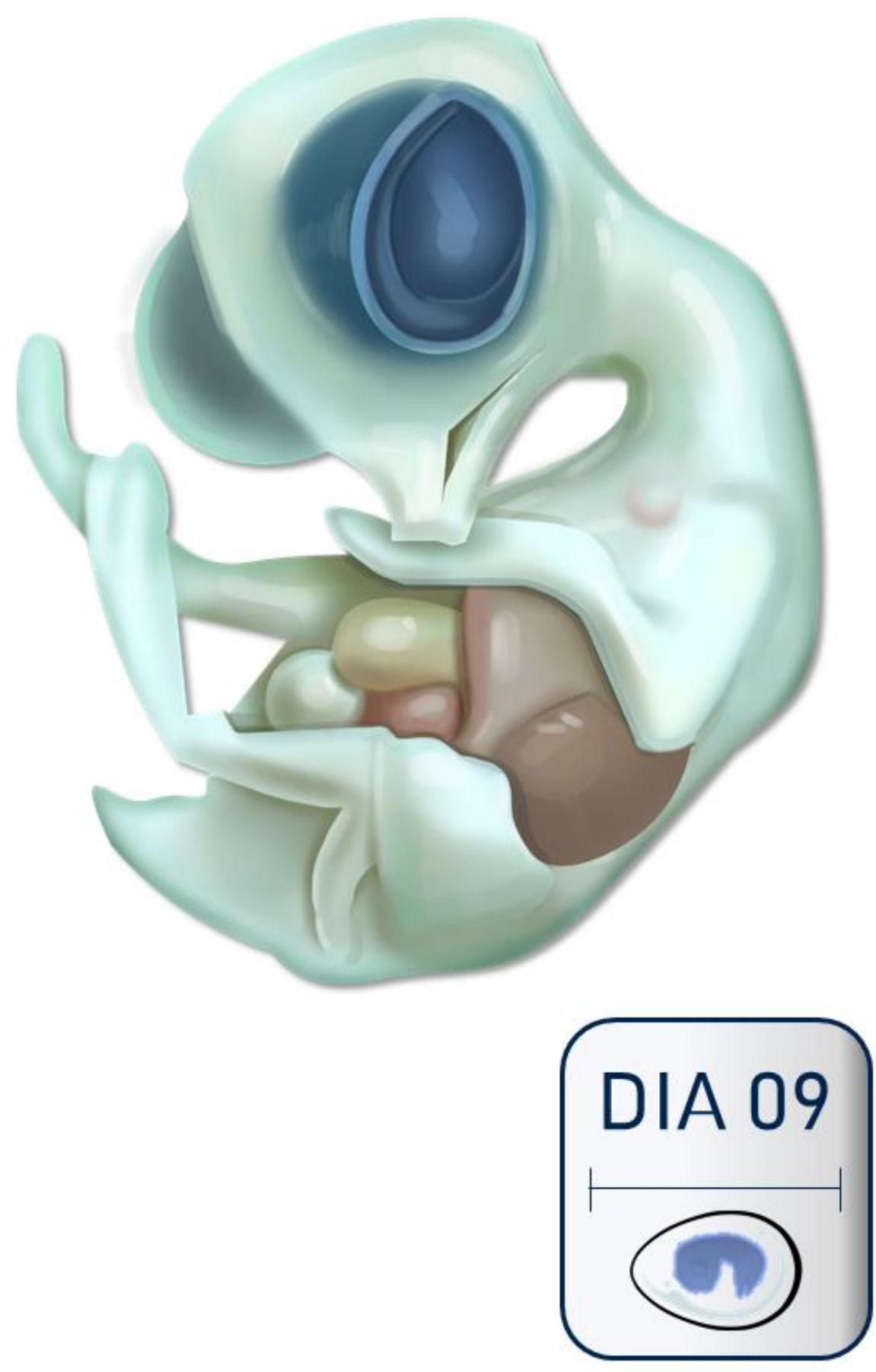




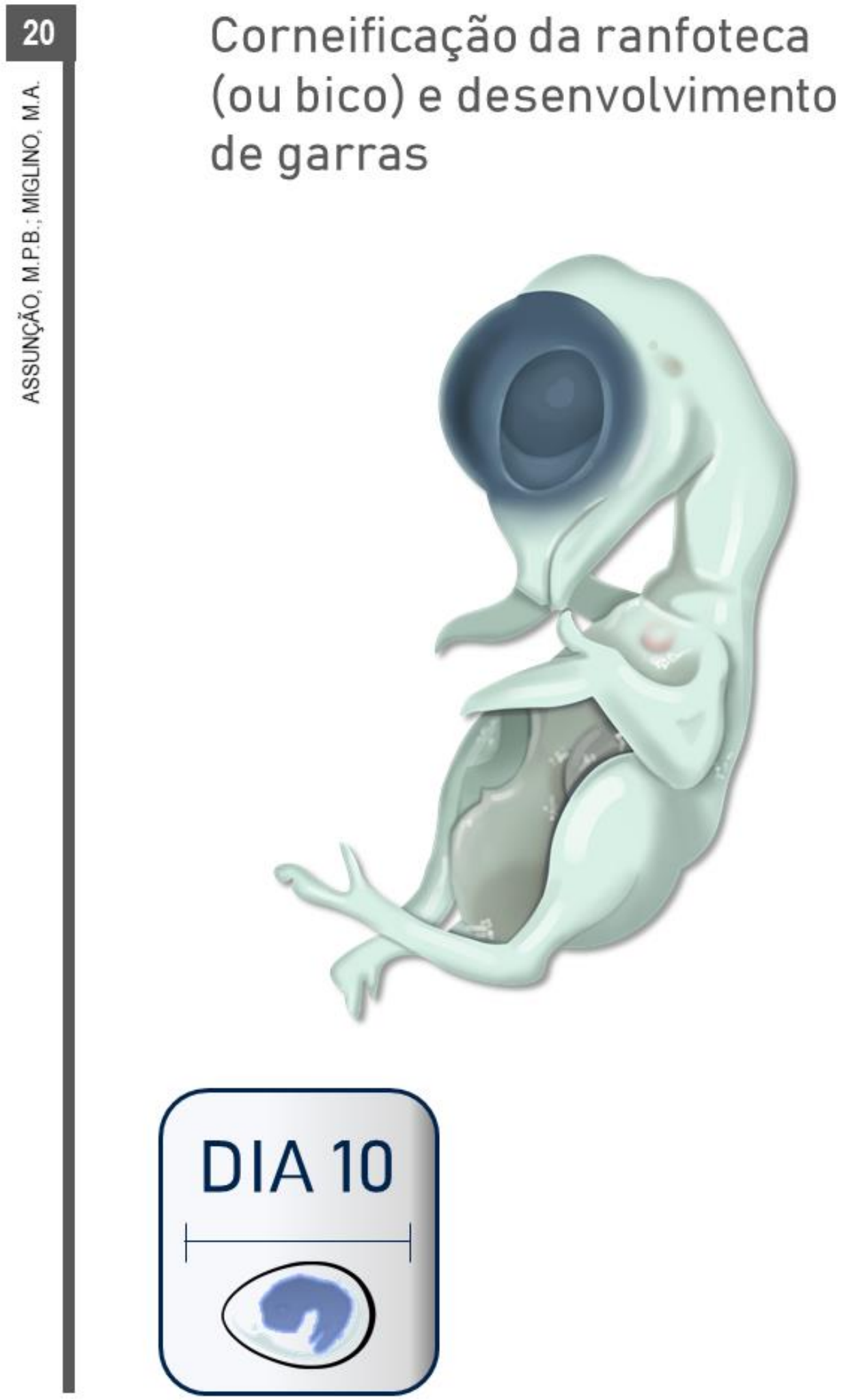


Desenvolvimento da penugem na cauda

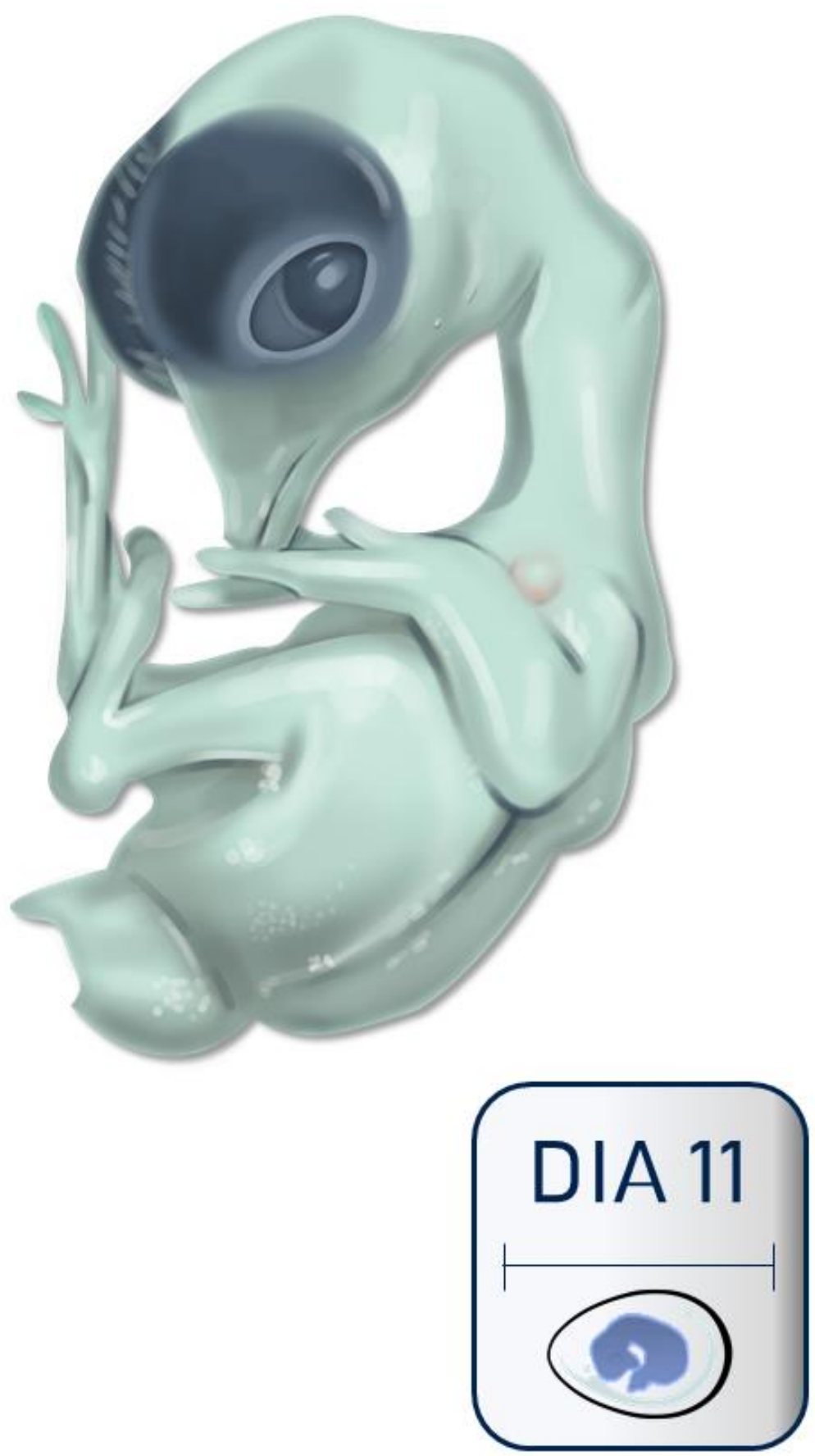

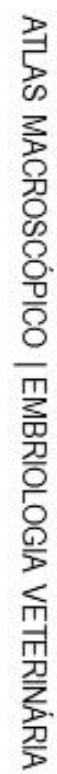




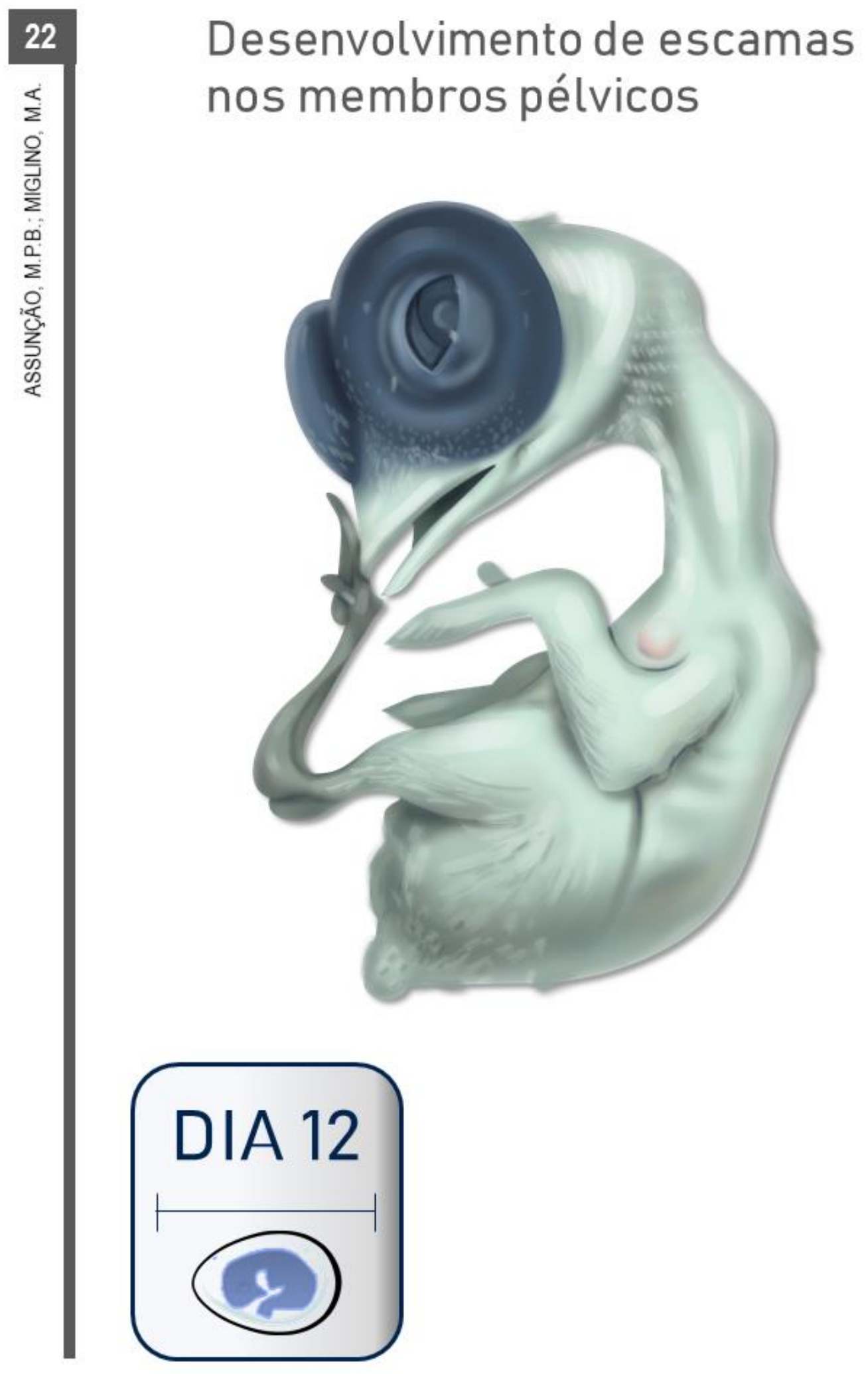


Desenvolvimento das pálpebras ópticas e complementação do desenvolvimento da orelha externa

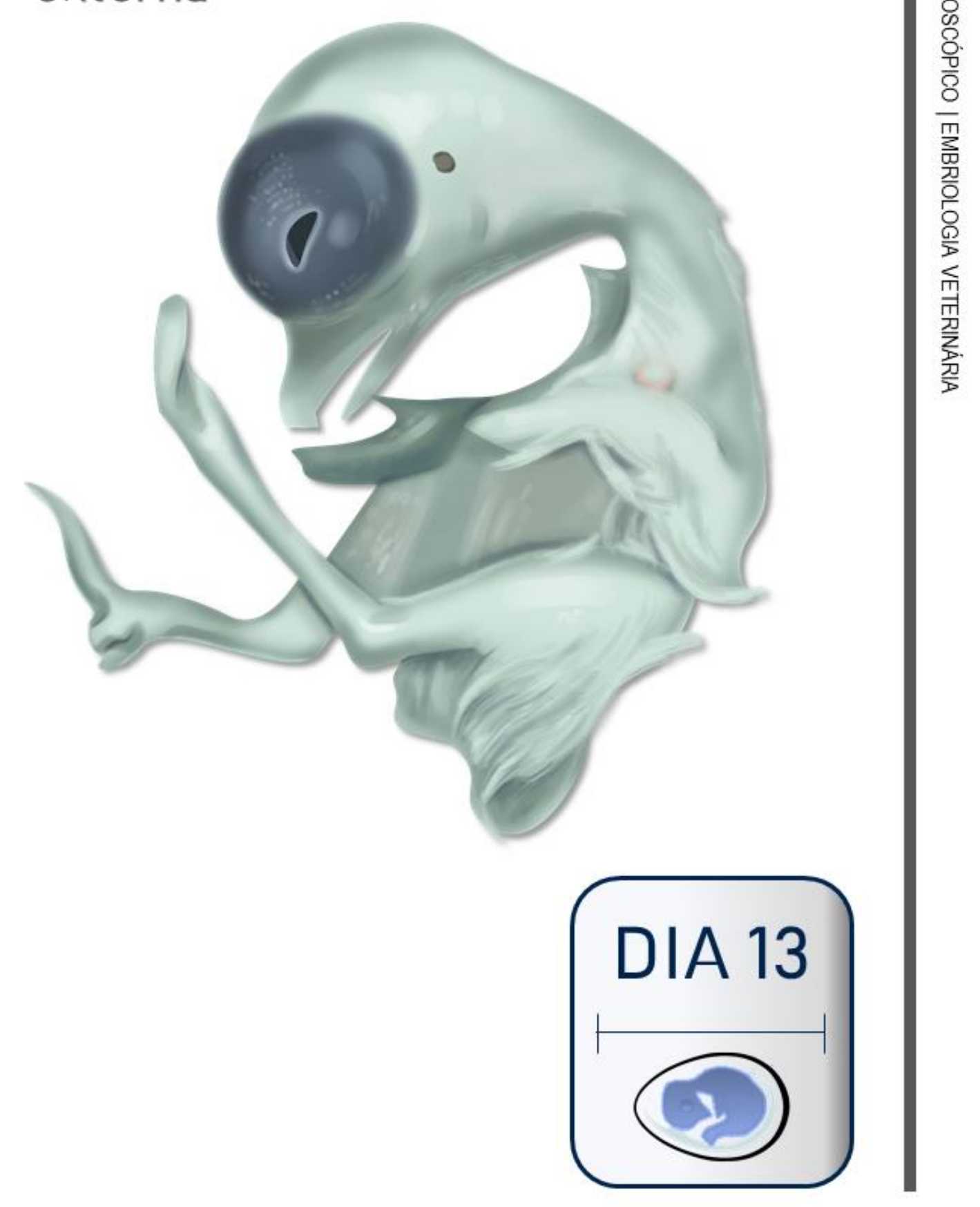




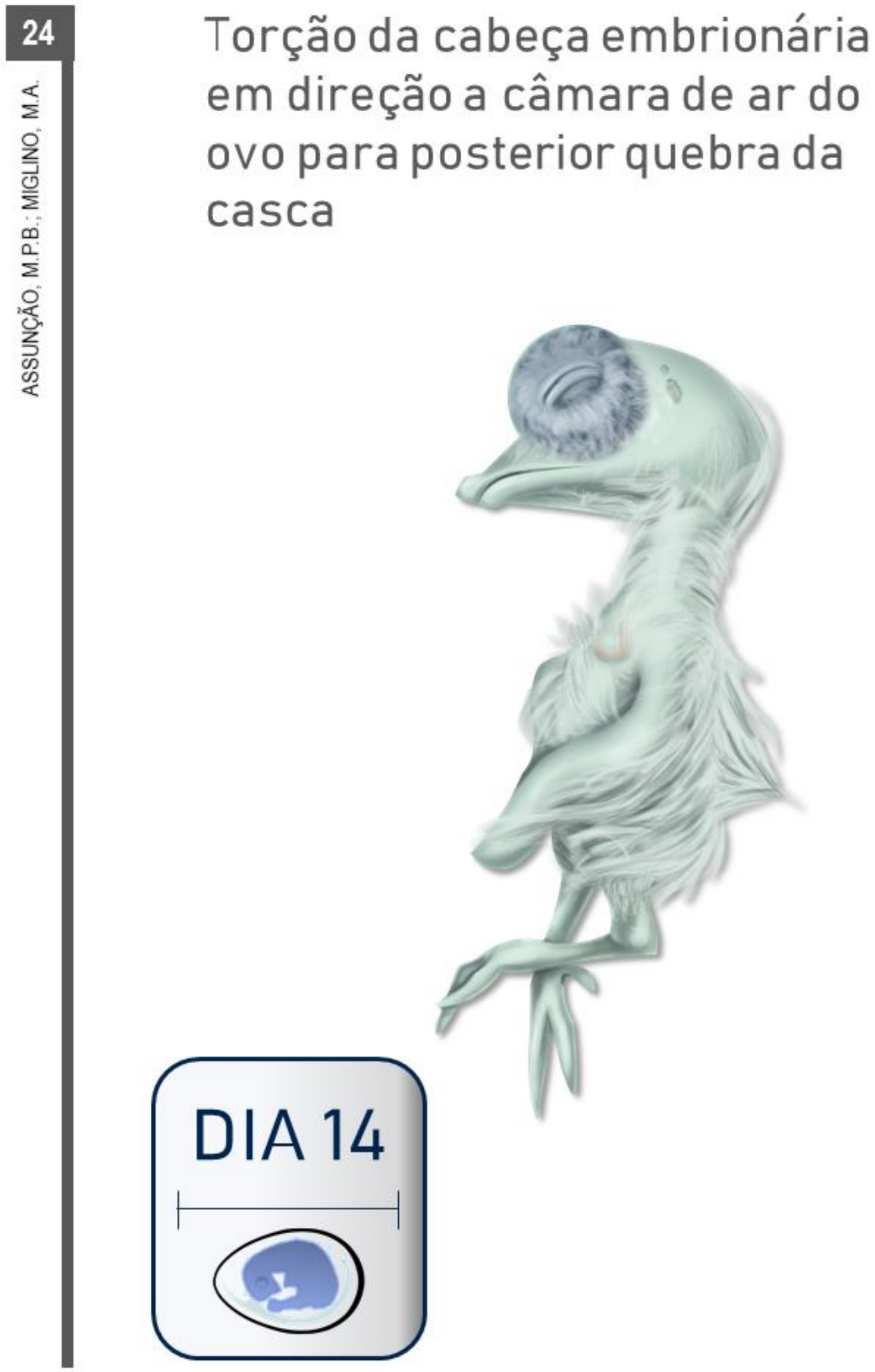


Posicionamento da cabeça embrionária para próximo do abdômen

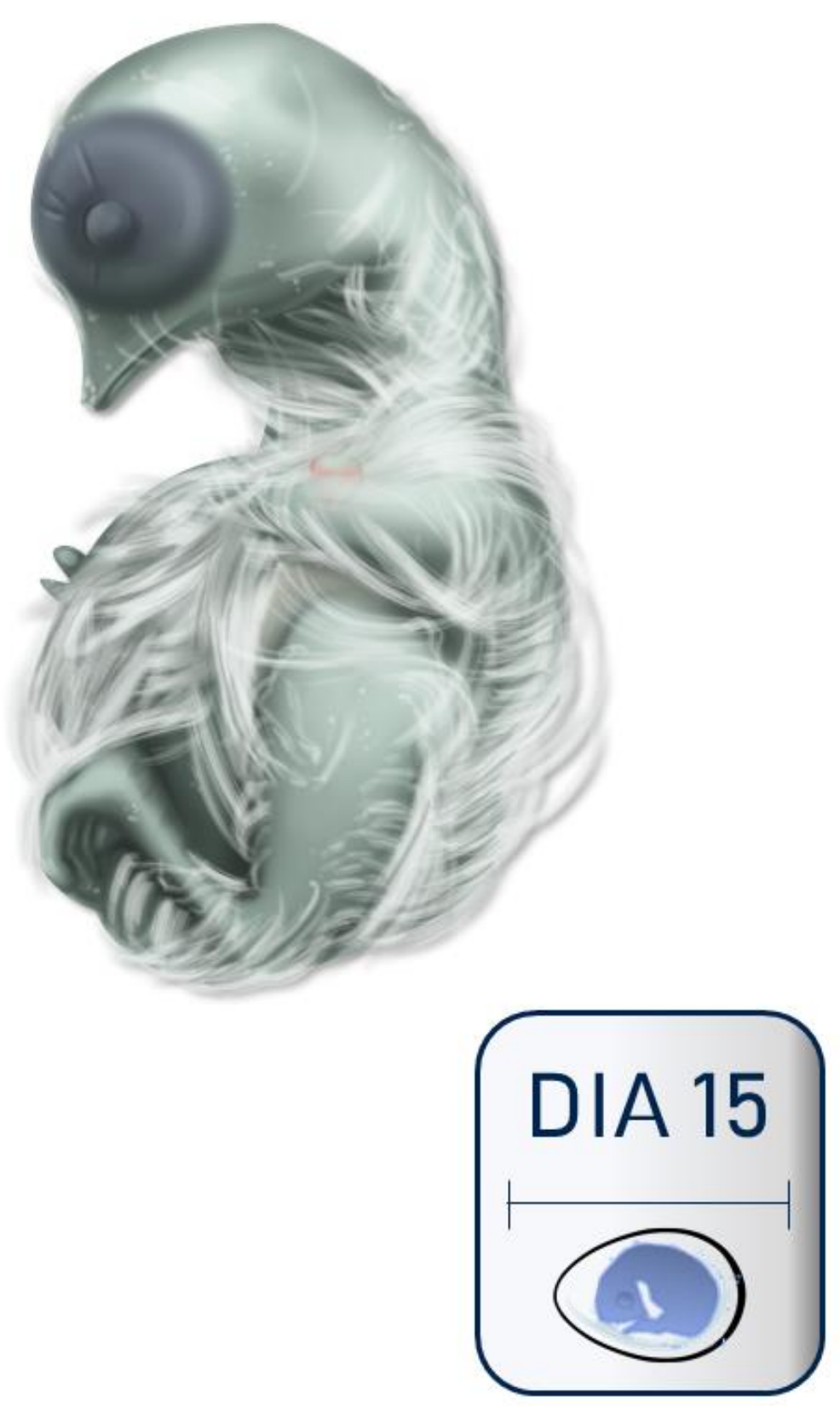




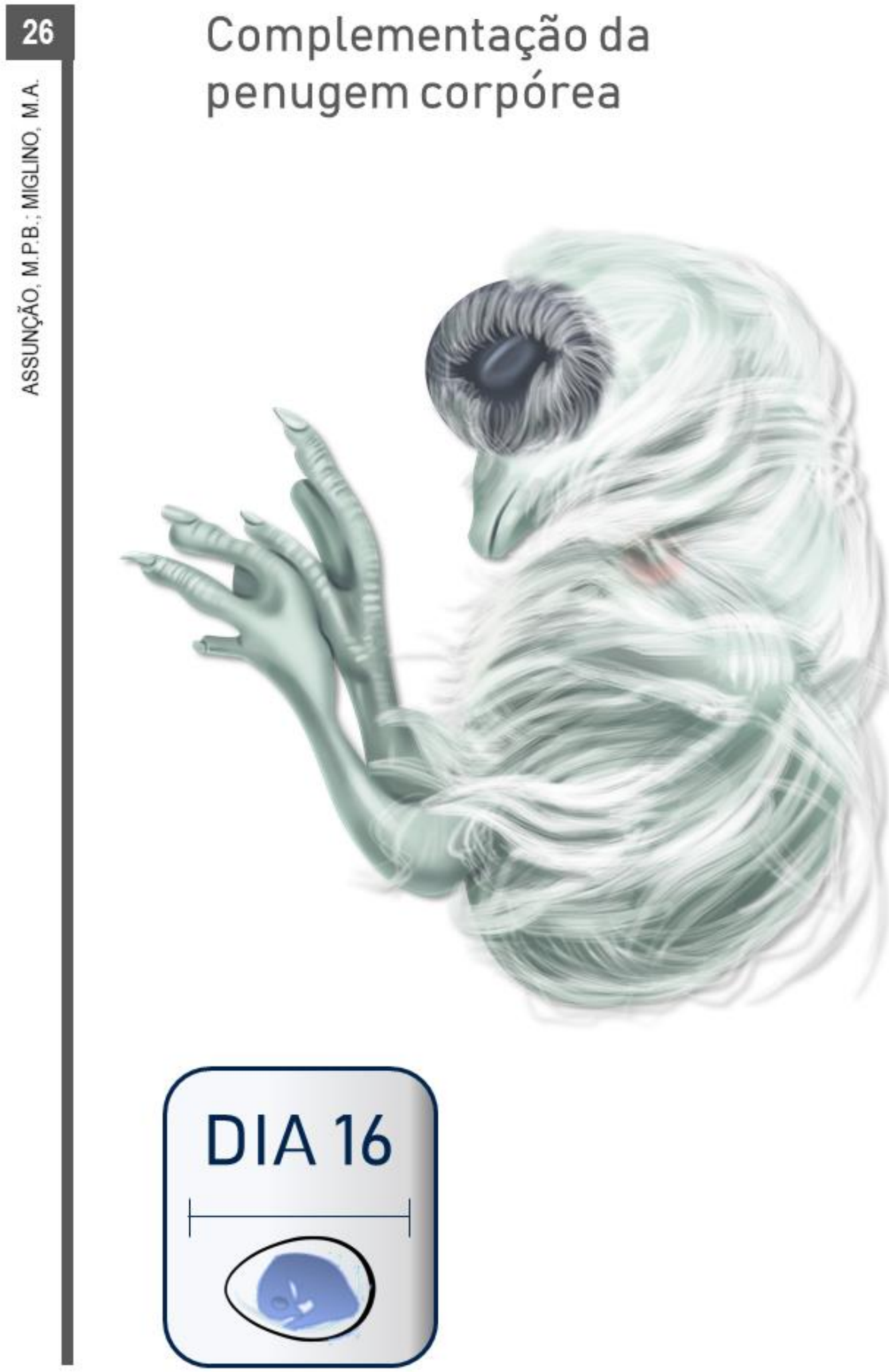


Direcionamento da ranfoteca (ou bico) para a câmara de ar do ovo
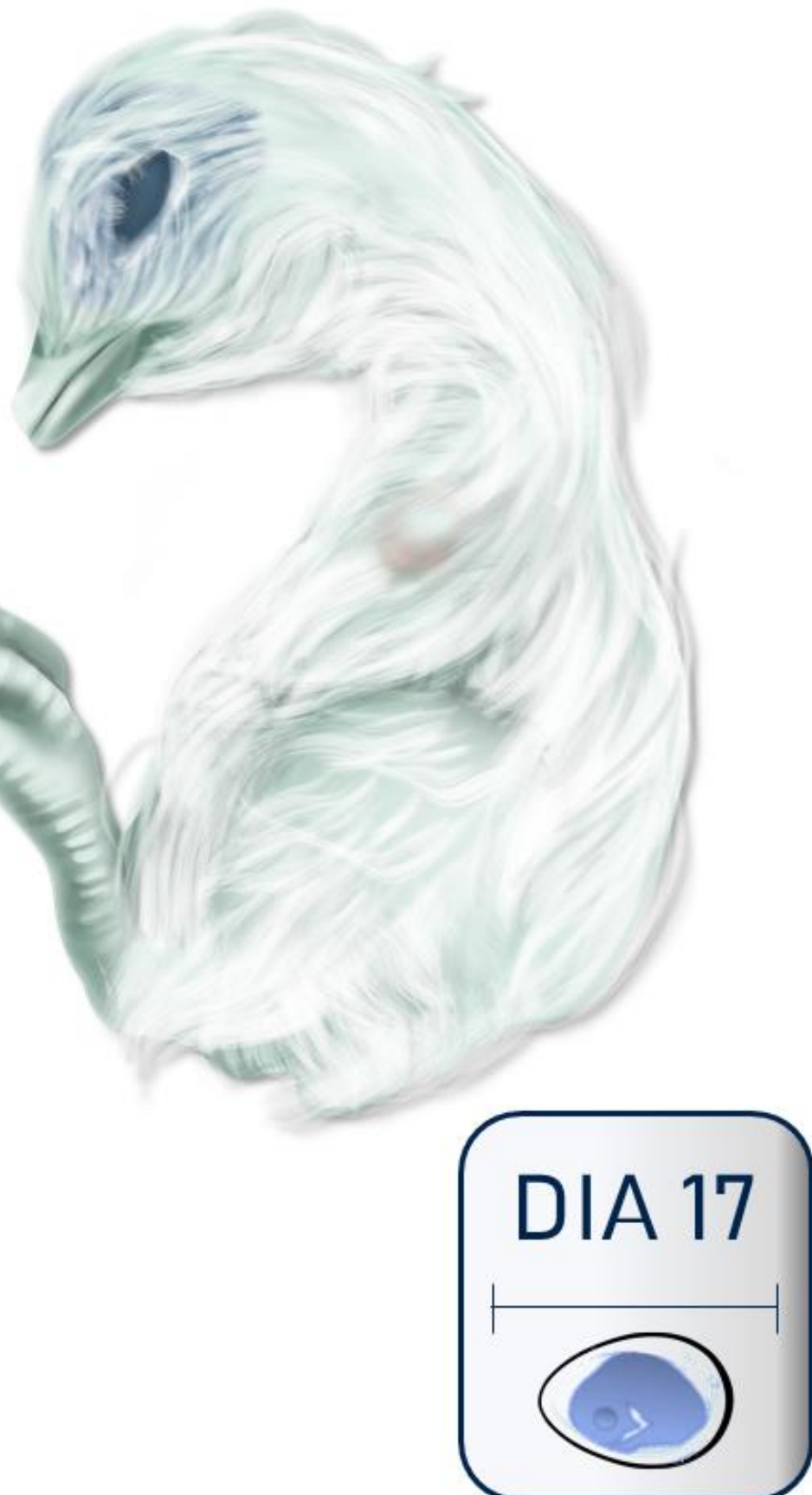


\begin{tabular}{l}
28 \\
28 \\
$\sum$ \\
0 \\
0 \\
$\sum$ \\
0 \\
\hline \\
0 \\
0 \\
2 \\
0 \\
0 \\
0 \\
0 \\
0 \\
0 \\
0
\end{tabular}

Crescimento fetal:

preenchimento de todo espaço

disponível no ovo, pelo corpo do concepto

\section{DIA 18}


Involução vitelínica: 0 saco vitelínico envolvido no desenvolvimento embrionário e fetal é completamente absorvido pelo concepto

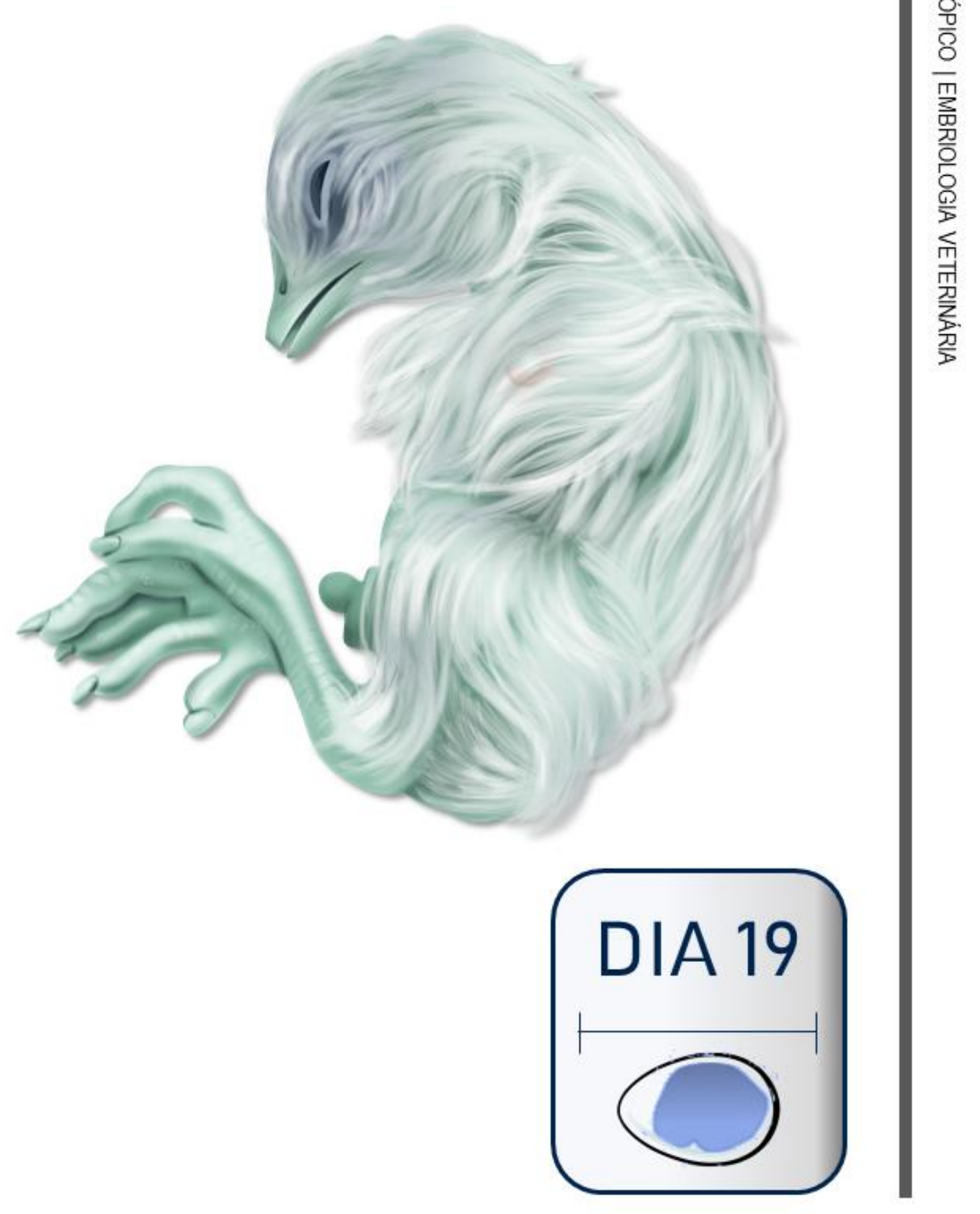




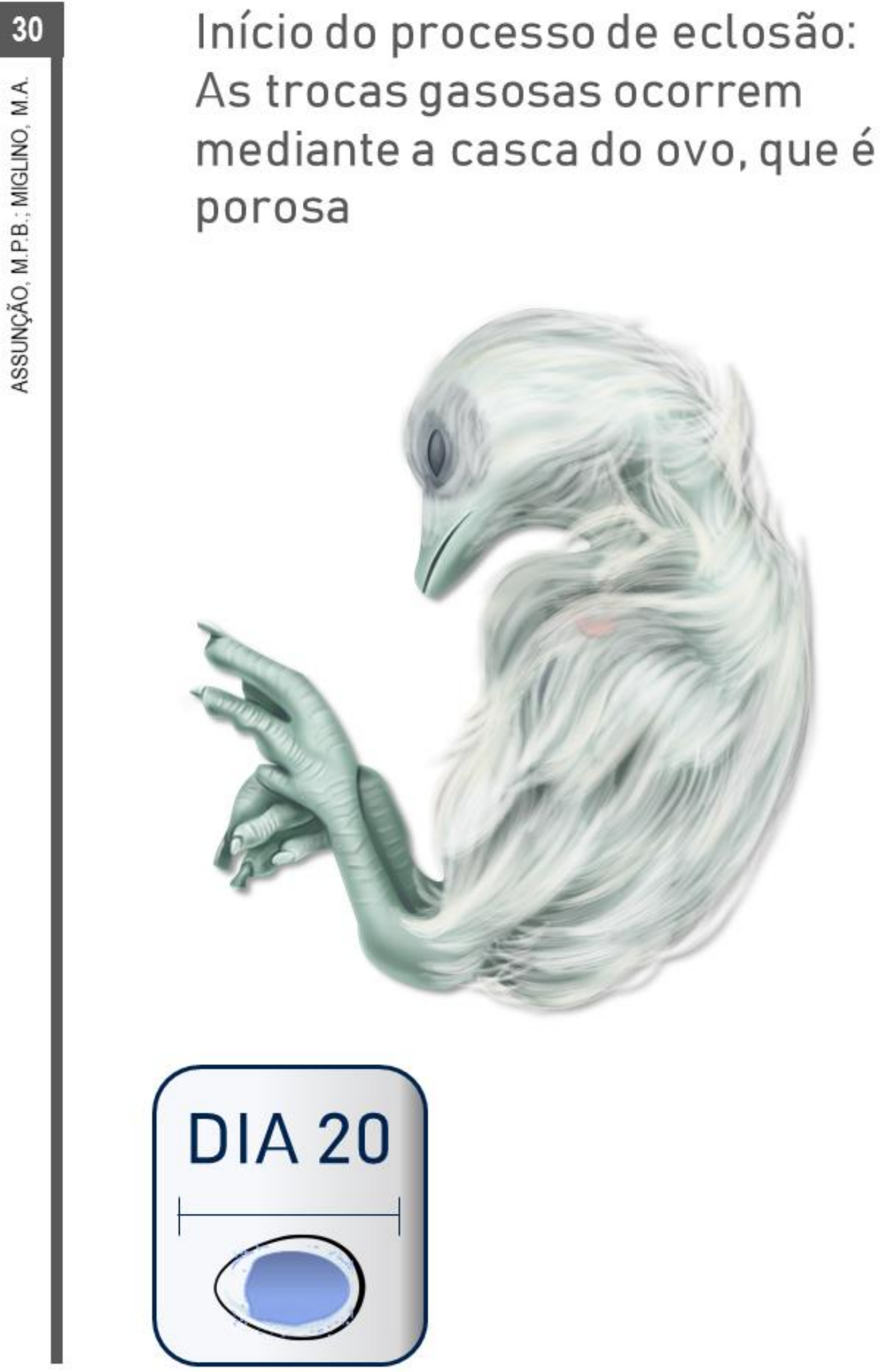


Nascimento

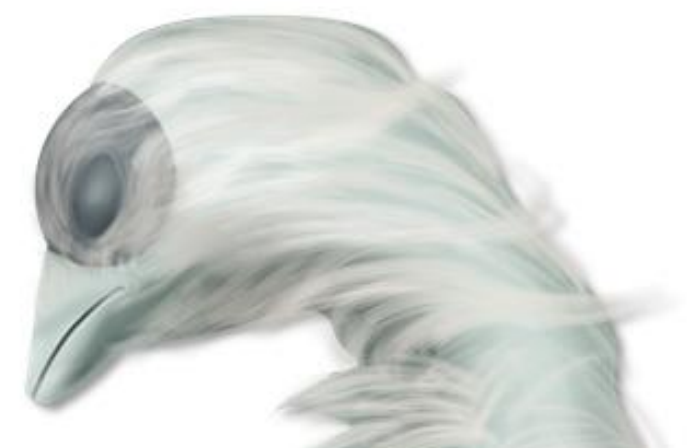

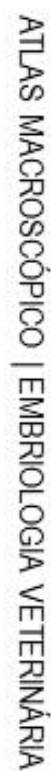

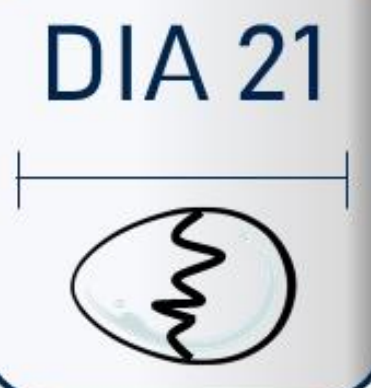


Idade e peso corporal dos

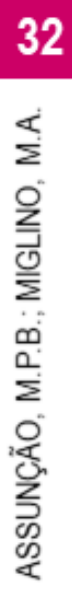
embriões e fetos coletados

\begin{tabular}{|c|c|}
\hline $\begin{array}{l}\text { IDADE } \\
\text { (Dias) }\end{array}$ & $\begin{array}{c}\text { PESO } \\
\text { (Gramas) }\end{array}$ \\
\hline 01 & 0,00 \\
\hline 02 & 0,00 \\
\hline 03 & 0,00 \\
\hline 04 & 0,00 \\
\hline 05 & 0,04 \\
\hline 06 & 0,15 \\
\hline 07 & 0,21 \\
\hline 08 & 0,83 \\
\hline 09 & 1,44 \\
\hline 10 & 1,64 \\
\hline 11 & 2,86 \\
\hline 12 & 3,86 \\
\hline 13 & 6,12 \\
\hline 14 & 8,27 \\
\hline 15 & 12,27 \\
\hline 16 & 14,21 \\
\hline 17 & 16,26 \\
\hline 18 & 18,30 \\
\hline 19 & 21,10 \\
\hline 20 & 23,45 \\
\hline 21 & 24,40 \\
\hline
\end{tabular}


Embriões e fetos utilizados como referência para transposição didática

DIA 01

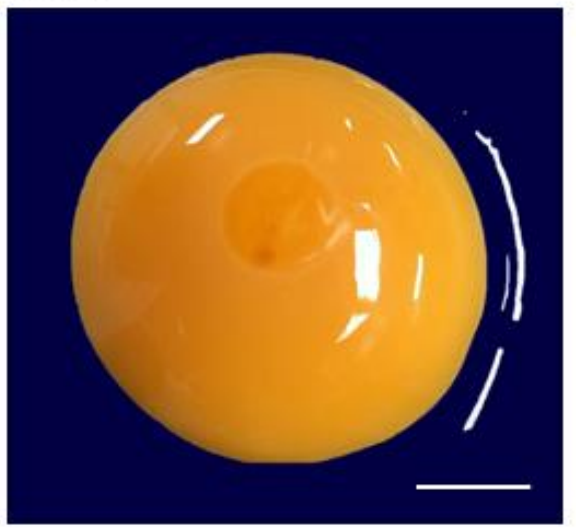

DIA 05

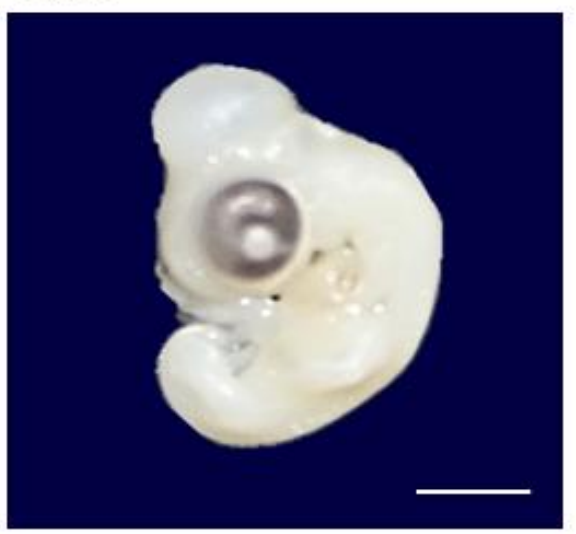

DIA 07

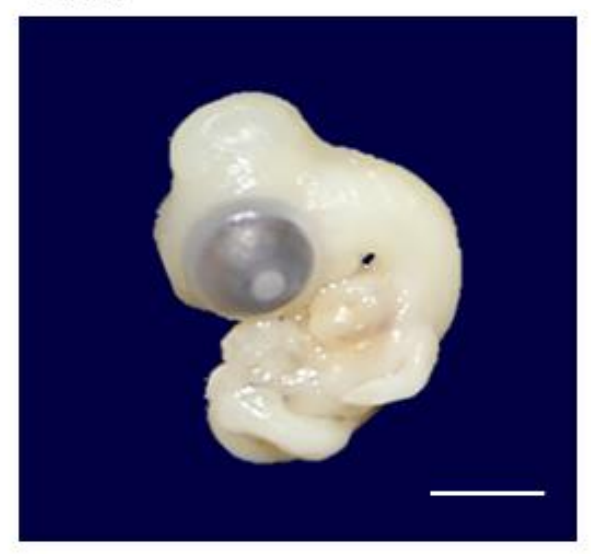

DIA 04

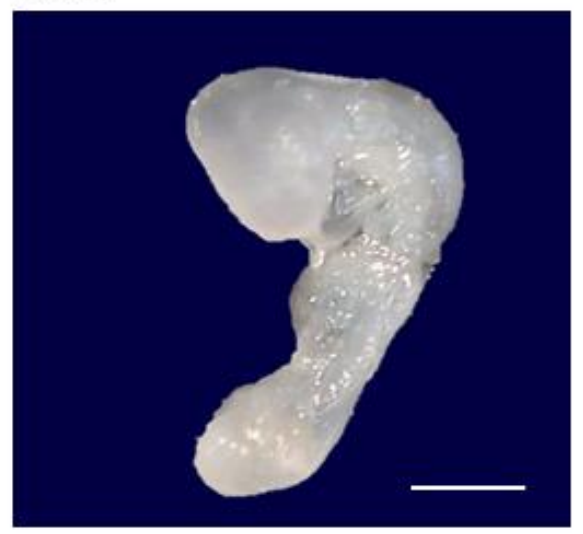

DIA 06

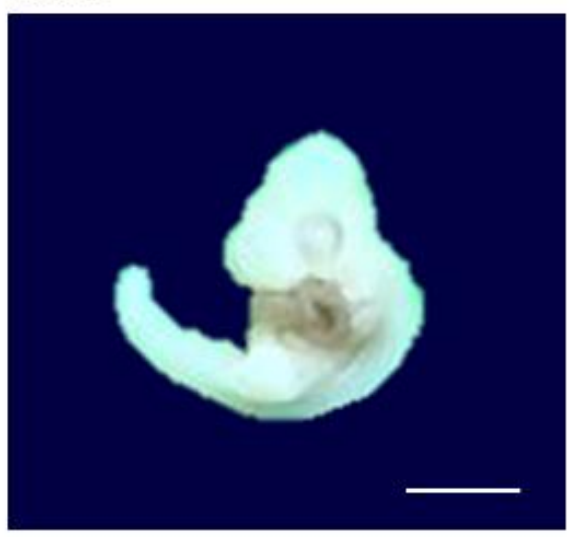

DIA 08

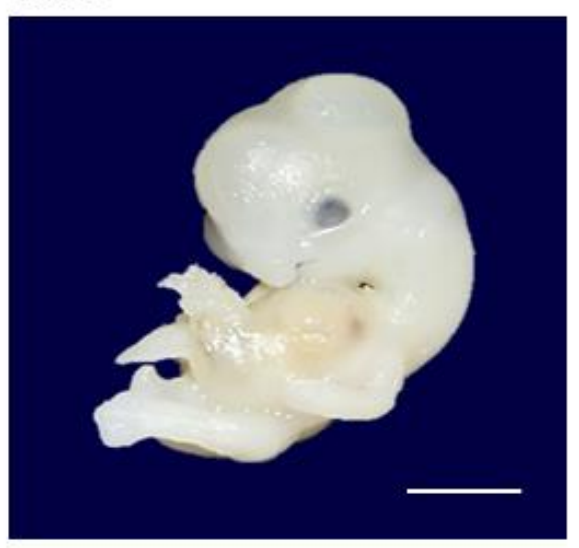

Barras referente a $2 \mathrm{~cm}$ 


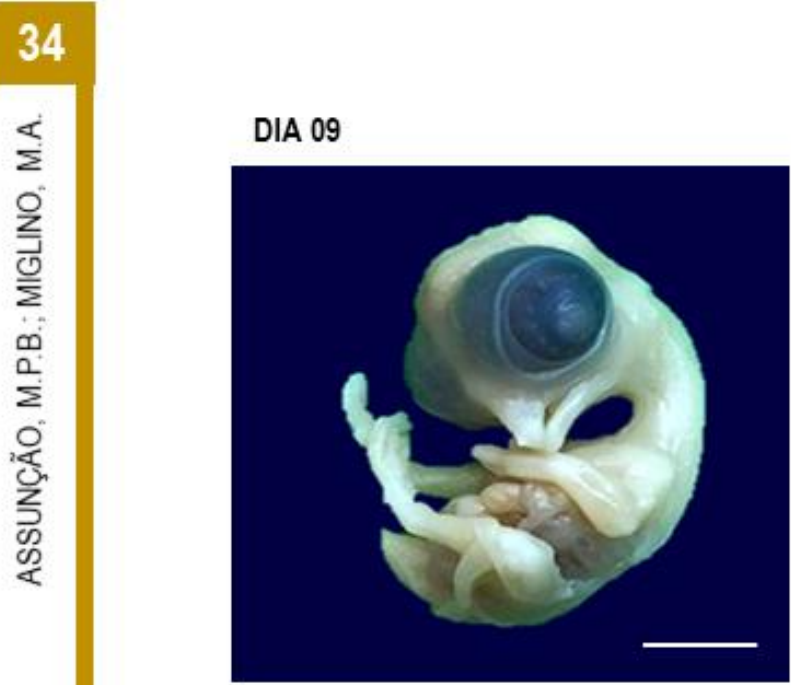

DIA 10

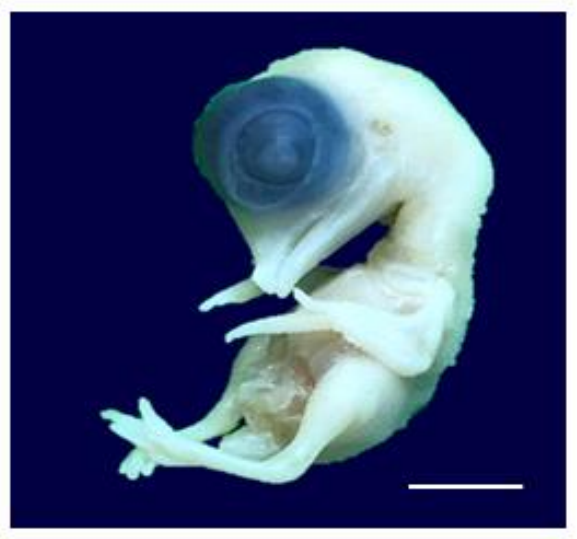

DIA 11

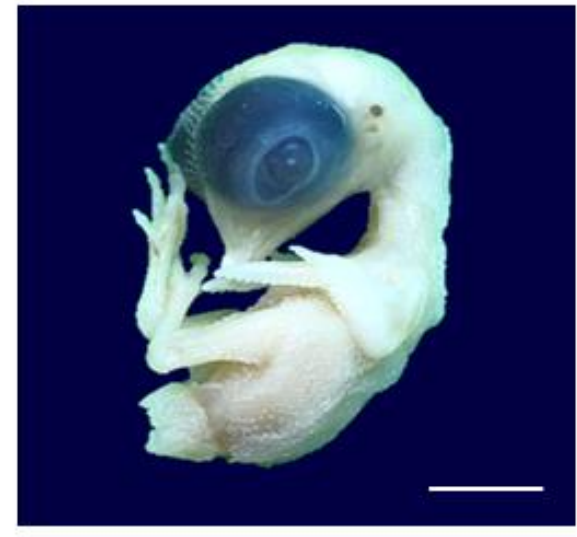

DIA 13

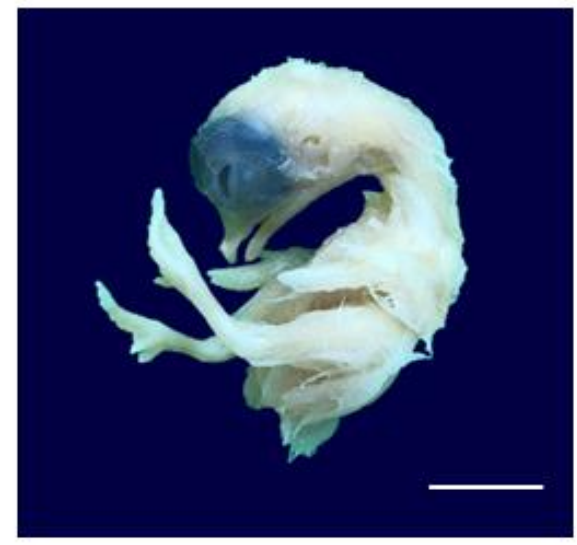

Barras referente a $2 \mathrm{~cm}$
DIA 12

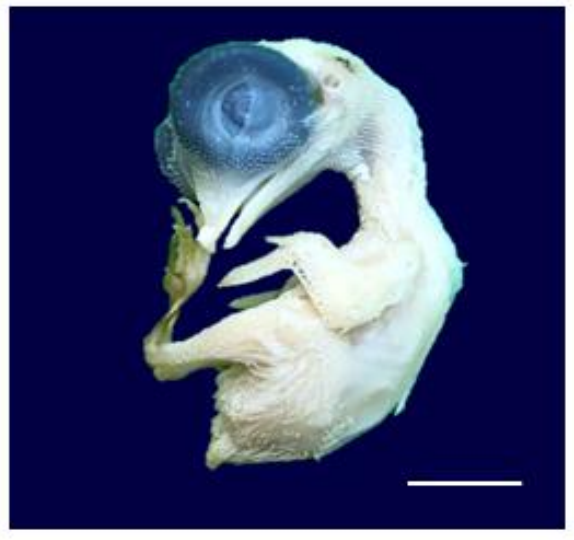

DIA 14

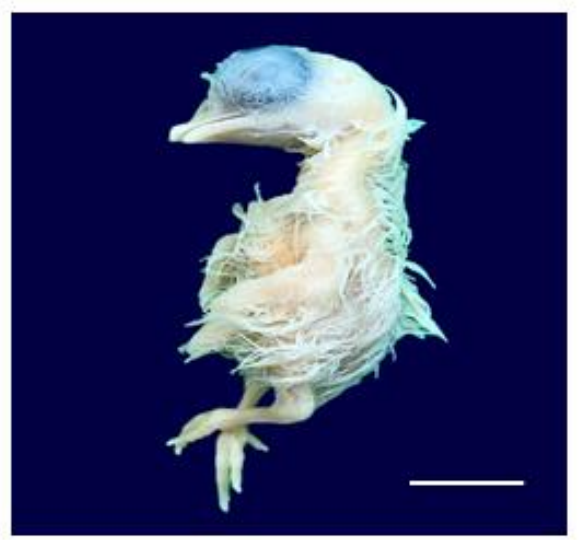


DIA 15

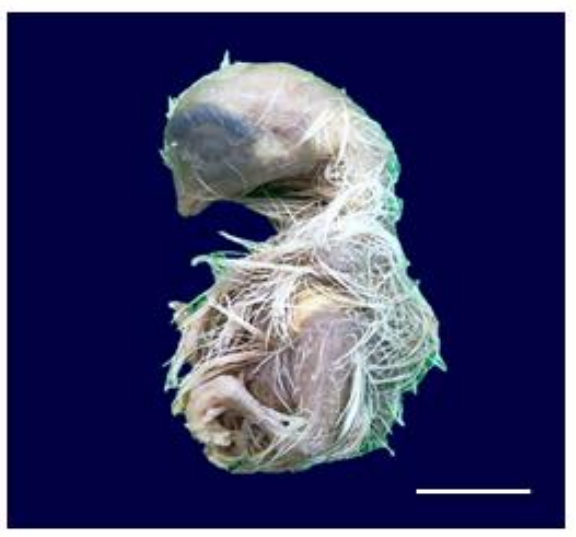

DIA 17

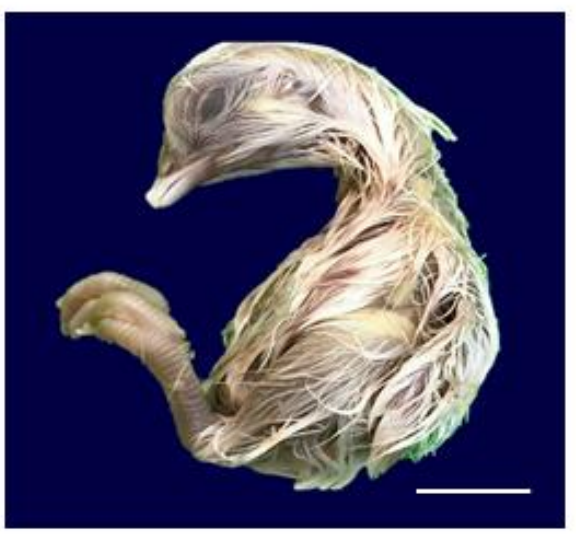

DIA 19

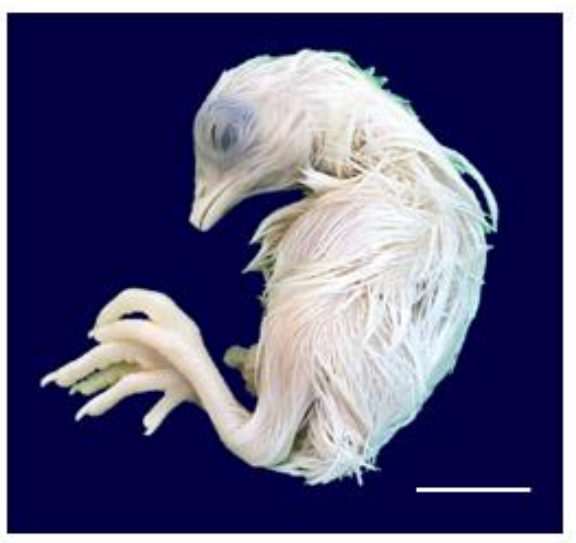

DIA 16

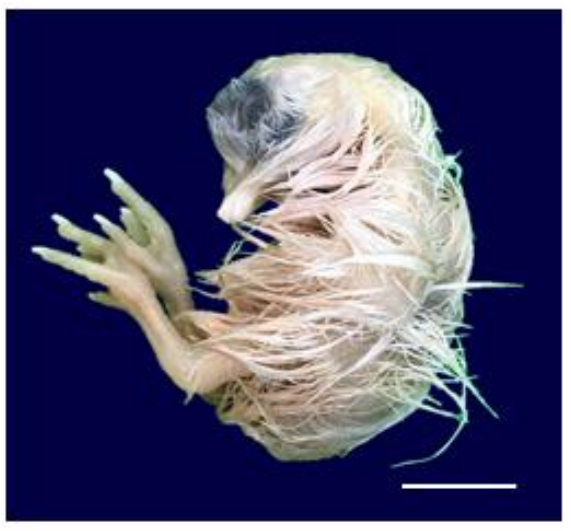

DIA 18

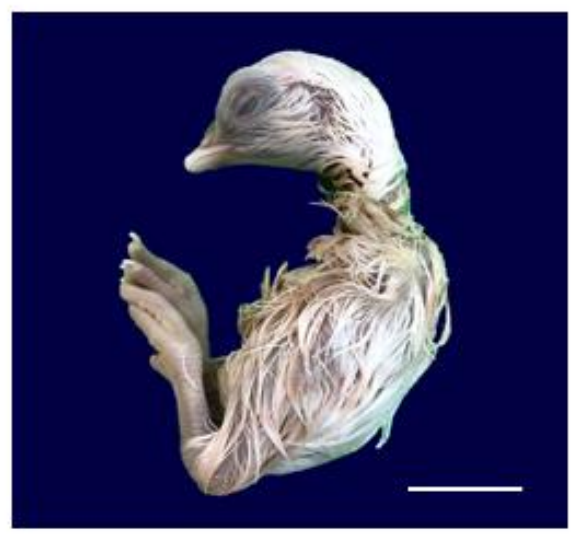

DIA 20

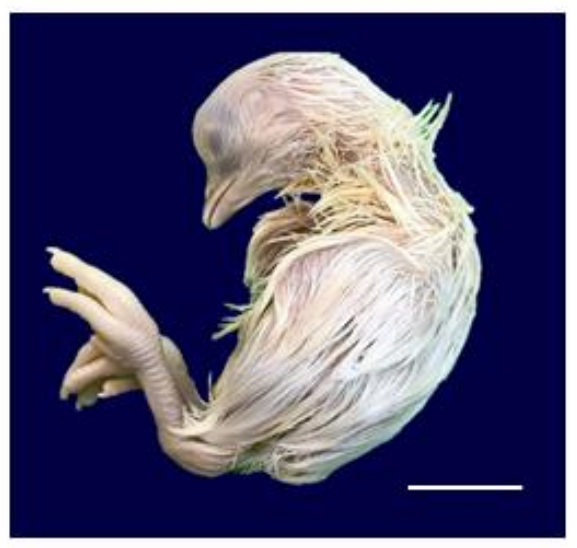

Barras referente a $2 \mathrm{~cm}$ 


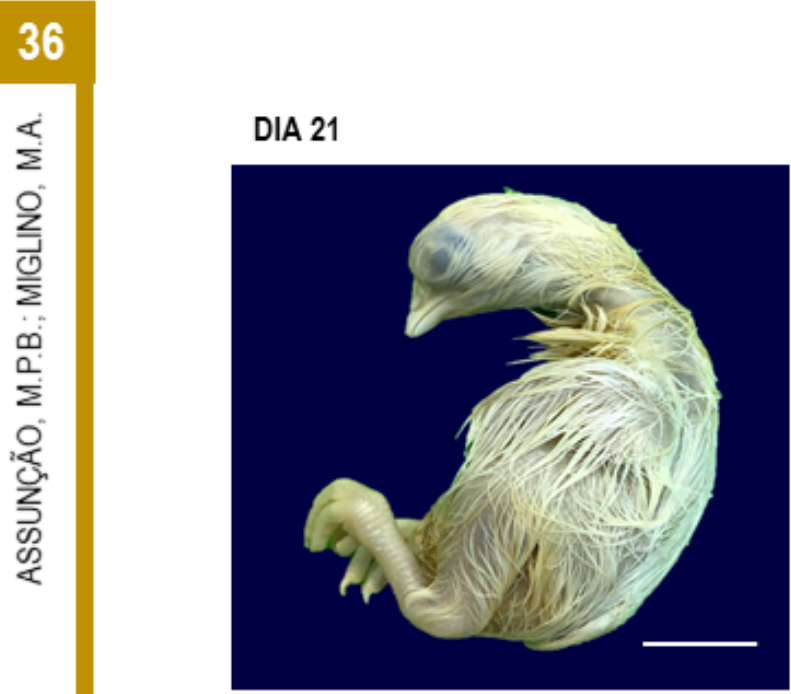

Barra referente a $2 \mathrm{~cm}$ 


\section{Notas importantes}

1) Os autores ressaltam que toda a bibliografia consultada foi criteriosamente informada. Cabe destacar que as imagens, em que a indicação de autoria não foi informada, foram produzidas pela equipe deste trabalho, tratando-se, portanto, de material próprio e original.

2) As opiniões, hipóteses e conclusões/recomendações expressas neste material são de responsabilidade dos autores.

3) É permitido exibir, traduzir, executar o conteúdo e ainda criar obras derivadas, sob as condições a seguir: Deve-se dar crédito ao autor original do conteúdo ou figura, da forma especificada pelo autor ou licenciante. Proibido utilizar o conteúdo com finalidade extra comerciais. Para cada novo uso ou distribuição, deve-se deixar claro as licenças de uso desta obra 


\section{Referências}

Ao longo do desenvolvimento deste trabalho, diversos achados disponiveis na literatura foram consultados, mas nossos estudos foram baseados principalmente nos textos voltados para a embriologia. Somos gratos especialmente aos autores das referências listadas abaixo:

BANKS, W. J. Applied Veterinary Histology, $3^{a}$ Ed. Mosby Year Book, St. Louis, 1993.

BELLAIRS, R.; MARK, O. O Atlas do Desenvolvimento de Pintos. Academic Press, San Diego, 1998

BRADLEY, O. C. A estrutura das aves. Oliver e Boyd, Londres, 1938.

FREEMAN, B. M. Fisiologia e Bioquimica da Galinha Doméstica. Academic Press, Londres, 1983.

GALDOS-RIVEROS, A. C., REZENDE, L. C., TURATTI, A. G., \& MIGLINO, M. A. (2010). A relação biológica entre o saco vitelino e o embrião. Enciclop Biosfera, 6, 1-13.

HAMBURGER, V.; HAMILTON, H. L. A series of normal stages in the development of the chick embryo. Developmental Dynamics., 195, 231-72. 1951.

HILL, M. A. Embryology Book - A Laboratory Manual and Text-book of Embryology 3. Acesso em: 04 de julho de 2020. Disponivel em: $\quad$ https://embryology.med.unsw.edu.au/embryology/index.php/Book_A_Laboratory_Manual_and_Text-book_of_Embryology_3

$\mathrm{KOCH}, \mathrm{T}$. Anatomia do frango e aves domésticas. Imprensa da Universidade Estadual de lowa, Ames, lowa, 1973.

MOORE, K. L. Anatomia Clinicamente Orientada, $2^{a}$ Ed.; Williams e Wilkins, Baltimore, 1985 .

NICKEL, R. Circulatory system. In: NICKEL, R.; SCHUMMER, A.; SEIFERLE, E. Anatomy of the domestic birds. Berlin and Hamburg: Verlag Paul Parey, 1977. cap 6, p. 85-103.

NODEN, M. D.; DE LAHUNTA, A. The Embryology of Domestic Animals - Developmental Mechanisms and Malformations. Baltimore: Williams \& Wilkins, 1985. 367p.

PATTEN, B. M. Embriologia precoce do pintainho, 4a Ed. The Blakiston Company, Londres 1952.

ROMANOFF, A. L.; ANASTASIA, J. O ovo aviário John Wiley \& Sons, Nova York, 1949.

STRAND, M. (2012). The egg and embryology. In R. Chapman (Author) \& S. Simpson \& A. Douglas (Eds.), The Insects: Structure and Function (pp. 347-397). Cambridge: Cambridge University Press. doi:10.1017/CBO9781139035460.019 


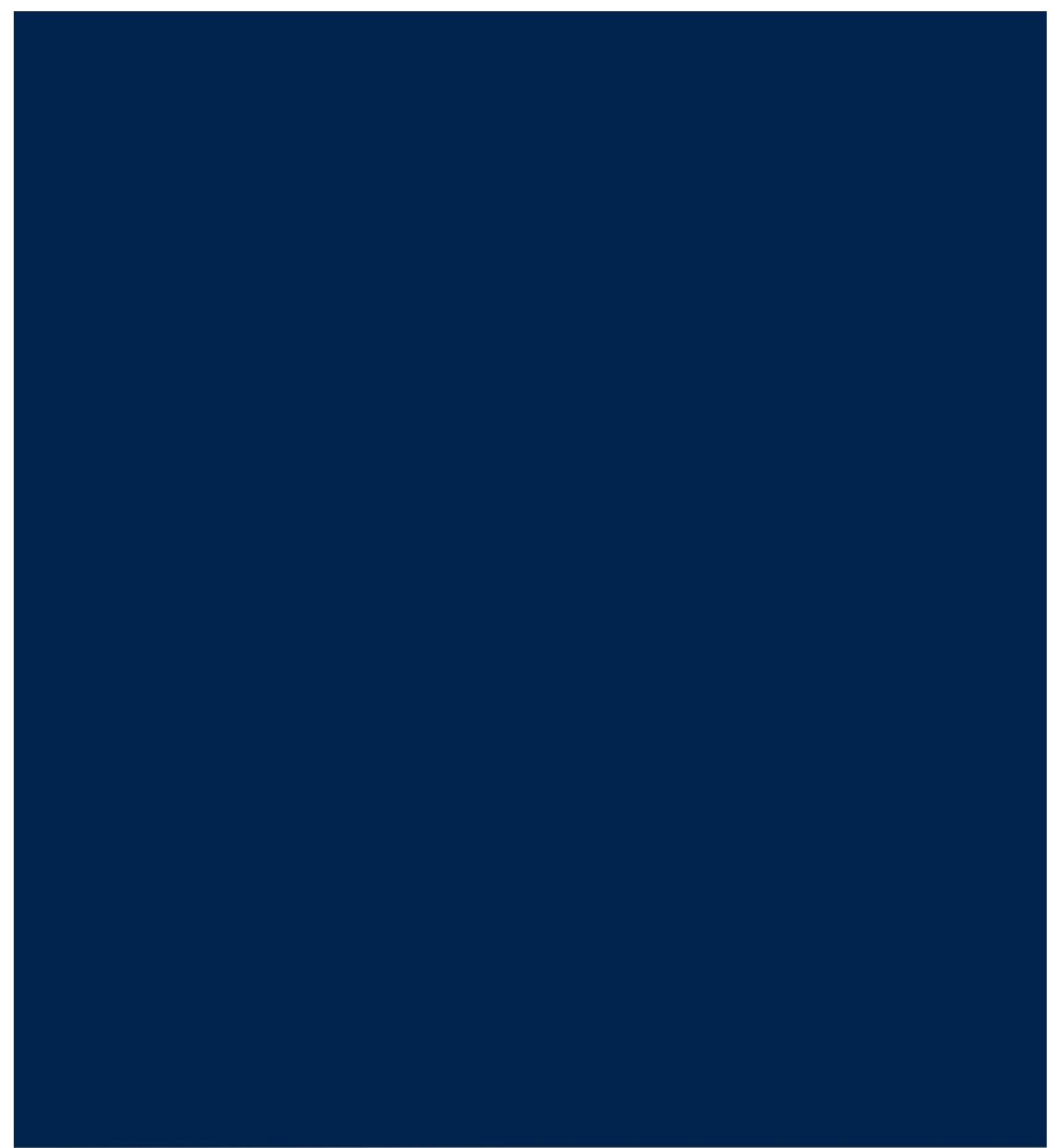

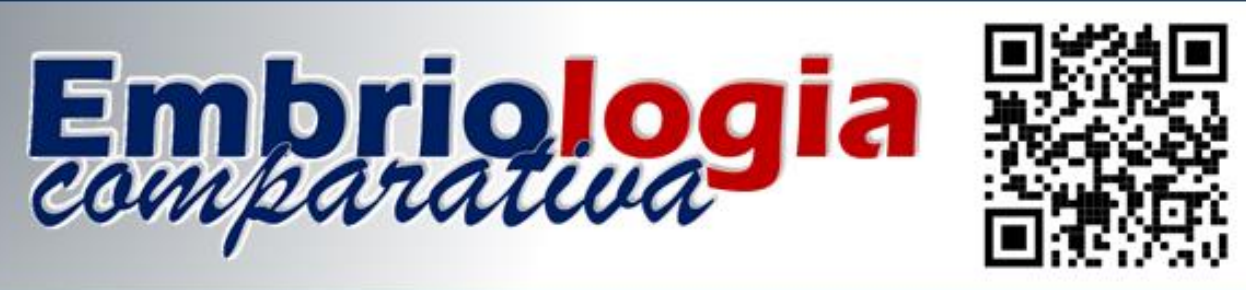


APÊNDICE F - Artigo I publicado sobre o tema

Grad+ Rev. Grad. USP, vol. 4, n. 1 jul 2020

\title{
Métodos Alternativos no Processo de Ensino-Aprendizagem em Embriologia Comparativa: Desafios e Perspectivas
}

\section{Alternative Methods in the Teaching-Learning Process in Comparative Embryology: Challenges and Prospects}

\author{
Marcos Paulo Batista de Assunção', Maria Angelica Miglino²* \\ 1Programa de Pós-Graduação em Anatomia dos Animais Domésticos e Silvestres da Faculdade de Medicina \\ Veterinária e Zootecnia da Universidade de São Paulo \\ Departamento de Cirurgia da Faculdade de Medicina Veterinária e Zootecnia da Universidade de São Paulo \\ *Autor para correspondência: miglino@usp.br
}

\section{RESUMO}

A embriologia comparativa é de extrema importância no processo de formação de profissionais da área da saúde, da biologia e até mesmo das agrárias. No campo macro e microscópico, observam-se estímulos para o desenvolvimento de novos métodos com a aplicação de diferentes abordagens pedagógicas. Nos cursos de graduação em Medicina Veterinária, Ciências Biológicas e até mesmo na Medicina Humana, o método tradicional de ensino vem passando por inovações semestre após semestre. O presente relato aborda os desafios e perspectivas no processo de ensino-aprendizagem acerca da embriologia comparativa e os novos possíveis métodos alternativos de inclusão neste ensino, verificadas por meio de uma revisão crítica. Desse modo, é possível verificar a partir da literatura consultada que o uso de recursos extras no processo de ensino-aprendizagem mostrase essencial e de fato mais eficaz para a aquisição de conhecimentos, mas, tendo em vista sua complexidade, é necessária uma abordagem de forma multidisciplinar.

Palavras-Chave:Ensino Superior; Embriologia Comparativa; Métodos Alternativos; Sistema Computacional; Plataforma Digital.

\begin{abstract}
Comparative embryology is of utmost importance on training professionals in health, biology and even agrarian fields. In the macro and microscopic field, the development of new methods with the application of different pedagogical approaches are observed. In undergraduate courses in veterinary medicine, life sciences and even human medicine the traditional method of teaching has been going through innovations. This article addresses the challenges and perspectives in the teaching-learning process about comparative embryology and the possible new alternative methods of inclusion in this teaching, verified through a critical review. Thus, it is possible to verify from the literature that the use of extra resources in the teaching-learning process proves to be essential and indeed more effective for the acquisition of knowledge, but, considering its complexity, an approach is needed in a multidisciplinary way.
\end{abstract}

Keywords: Higher Education; Alternative Methods; Computer System; Digital Platform.

\section{Introdução}

O estudo da embriologia comparativa faz parte das Ciências Morfológicas e se faz fundamental na formação de futuros profissionais tanto da área da saúde quanto das agrárias e/ou biológicas. Assim, dificuldades de aprendizagem são encontradas nessa área, uma vez que as aulas são ministradas de forma superficial e não abordam o desenvolvimento e as mudanças simultâneas que ocorrem nas mais diferentes espécies de embriões. No entanto, todo conteúdo relacionado com a embriologia apresenta-se de forma complexa e rica em detalhes macro e microscópicos; uma vez abordado de forma superficial, pode gerar 
barreiras no aprendizado do aluno, fazendo com que o mesmo não visualize as inter-relações dos conceitos existentes que ocorrem na formação do indivíduo (CARNIATTO, 2002; DUMM, 2006; MELLO, 2009).

De modo mais específico, o conhecimento a ser herdado da embriologia possibilita um saber mais aprofundado sobre o desenvolvimento quando comparado entre as diferentes espécies existentes. Isso contribui para uma formação global dos estudantes, seja a nível médio ou superior. Todo seu conhecimento configura-se como um tema largamente veiculado na mídia, por meio de debates sobre reprodução, melhoramento genético, clonagem e até mesmo sobre aborto na adolescência, sendo este último quando se trata da embriologia humana (MOUL et al., 2017).

Nesse contexto, o ensino superior é considerado como o instrumento principal de informações avançadas, assumindo o papel de transmissão científica que reúne um conjunto de funções tradicionais associadas ao progresso e transmissão do saber: pesquisa e inovação, ensino e formação, e ensino a distância $(\mathrm{EaD})$. Todo este progresso e transmissão do saber discutido nos dias atuais é relevante para que se aproxime e possibilite aos estudantes um conhecimento científico mais apropriado com o tempo e espaço, constituindo-se um verdadeiro desafio para transpormos as barreiras do ensino tradicional na Medicina Veterinária, Ciências Biológicas e afins, uma vez que, no Brasil, a taxa de inclusão de jovens entre 18 e 24 anos em instituições públicas e privadas ainda é uma das mais baixas da América Latina (MELO, MELO \& NUNES, 2009).

\section{Importância do Estudo da Embriologia Comparativa}

A embriologia comparativa representa um vasto caminho para a compreensão das relações filogenéticas para os mais diversos grupos animais. Com isso, todo estudo concomitantemente ligado a esta ciência gera forças às discussões sobre o desenvolvimento dos animais quando comparados simultaneamente, deixando mais claro e conciso o processo de desenvolvimento dos sistemas que atingem seu estado funcional no organismo (GILBERT, 2003).

Para Hall et al., (1992) os componentes ambientais têm, por vez, uma forte ligação com os processos de desenvolvimento, interagindo e representando desde o meio celular até o ambiente externo. Os sistemas em processo de formação inicial são extremamente dependentes das condições ambientais nas quais estão inseridos. A formação do embrião com relação ao seu desenvolvimento padrão é controlada por mecanismos conservadores e que são compartilhados por grandes e variados grupos de espécies. Já as modificações ocorrentes nesses padrões são as principais causas das variações observadas entre os animais domésticos (SLACK, 1993; RICHARDSON, 1999).

Desse modo, com a existência e necessidade intrínseca de interações entre partes em que se observa a não correspondência entre genótipo-fenótipo é que se podem estabelecer inter-relações por meio da embriologia, abordando questões referentes ao desenvolvimento individual de cada espécie (diferenciação, morfogênese, funcionalidade, crescimento) e também elencar como as variações em processos de desenvolvimento podem ser observadas em níveis macro e microscópicos, de forma a gerar uma diversidade de planos estruturais e morfológicos quando comparados simultaneamente.

\section{Uma Breve Abordagem Descritiva sobre - Método Tradicional de Ensino em Embriologia}

Em sua etimologia, a palavra de origem grega (embrio - embrião, logos - ciência) tem como significado "a ciência que estuda os embriões", isto é, o estudo descritivo ou experimental das mudanças na forma do embrião. O processo de ensino-aprendizagem nessa disciplina é de extrema importância para compreender os processos de desenvolvimento e até mesmo as más formações congênitas que podem afetar a vida do futuro organismo. Para tanto, todo conhecimento que propicia os saberes dos primórdios é de grande relevância no processo de 
ensino-aprendizagem, ou seja, um pilar fundamental para o conhecimento biológico e médico veterinário (HYTTEL, SINOWATZ \& VEJLSTED, 2010).

Pensando no panorama de práxis acadêmica, o ensino tradicional de Ciências (desde a educação básica ao ensino superior) apresenta pouca eficiência, segundo Jotta (2005), seja na perspectiva tanto dos discentes quanto dos docentes, ou até mesmo na sociedade. Os saberes acerca do desenvolvimento animal vêm elucidar os processos da gametogênese, fecundação e organogênese, possibilitando, de forma detalhada, observar a disposição e a estruturação de órgãos e tecidos até o nascimento do indivíduo (ZERBINI \& ABBAD, 2008; MOORE \& PERSAUD, 2008; HYTTEL, SINOWATZ \& VEJLSTED, 2010).

Historicamente, Gummery et al. (2017) reportam que o processo de ensino-aprendizagem tanto em anatomia quanto em embriologia faz uso de peças reais para a prática de dissecção; com isso, tem sido referência de qualidade para conhecimentos em estudos submetidos a análises tanto macro quanto microscópicas. Sabendo da vasta discussão que rege este ensino, até mesmo com relação às ponderações a respeito de vantagens e desvantagens desse método tradicional de aprendizagem, tal ocorrência é tratada de forma sucinta nos dias de hoje. Apesar dos desafios, a abordagem tradicional que permite a visualização real e o desenvolvimento de práticas laboratoriais com bisturi em mãos é considerada um pilar importante (WILSON et al., 2017).

No Brasil, em 2008, com a aprovação da Lei 11.794 (Lei Arouca) foram levantadas discussões sobre a legislação brasileira quanto à preocupação de regulamentar o uso de animais em práticas didáticas ou científicas, bem como a perspectiva de reduzir o número destes submetidos à experimentação. Mas, na verdade, a vigência da atual legislação para a criação e a utilização de animais voltadas a ensino e pesquisa impõe limites à prática: levando em consideração a proteção dos animais, preconiza o planejamento do experimento para utilizar o menor número possível de animais, evitando estresse, dor ou sofrimento desnecessários e instigando a comunidade acadêmica e científica à idealização de novas metodologias de ensino na Medicina Veterinária e áreas afins (GUIMARÃES, 2016).

\section{Desafios e Perspectivas da Implementa- ção de Recursos Tecnológicos para Fins Didáticos}

A literatura tem mostrado que a aprendizagem passiva dos alunos não é satisfatória, suscitando interesse e gerando polêmica com relação aos papéis que os padrões de ensino deveriam assumir para melhorar a sua qualidade a nível superior, propondo uma nova perspectiva de ensino baseada na integração e inserção de recursos tecnológicos, de forma a associar o ensino tradicional a essas modernas ferramentas pedagógicas.

Nesse contexto, dois pontos principais vêm sendo discutidos: a equidade (tema central em políticas públicas no âmbito educacional) e o impacto sobre a aprendizagem. Mesmo que muitas vezes façam parte das relações cotidianas, ferramentas inovadoras de aprendizagem no ambiente das instituições públicas são vistas como um desafio para a formação dos futuros profissionais (McGUSKEY et al., 2005; CARNEIRO-LEÃO, SÁ \& JÓFILI, 2010; MONTIEL, 2014).

De acordo com Ghosh (2017), os recursos tecnológicos que podem ser usados a favor da embriologia e também no âmbito educacional voltado para o ensino da anatomia, bem como da era digital em que os aprendizes estão inseridos, passam por um dilema com relação a sua inserção, apresentando uma questão que muitas vezes se descarta: a dificuldade da implementação de recursos digitais para a construção de um conhecimento mais didático, os quais estão bastante presentes no contexto internacional e que aumentariam a possibilidade de acesso ao conteúdo tanto teórico quanto prático a alunos de diferentes níveis socioeconômicos, favorecendo a equidade.

Analisando os estudos, nota-se que existe um importante paralelo: países da União Europeia e os Estados Unidos da América apresentam uma introdução precoce no uso de tecnologias em todos os estágios estudantis com a implementação 
progressiva de novos recursos tecnológicos, incluindo universidades de prestígio com a experiência histórica como, por exemplo, no ensino da anatomia por materiais clássicos. Para além disso, uma melhor percepção e aceitação por parte dos discentes e dos docentes das novas ferramentas de ensino são favoráveis com relação ao real incremento no aprendizado. Um dos estudos mostra também que existe uma alta percepção da utilidade da mídia digital na aprendizagem, manifestada por 96,55\% dos estudantes pesquisados, dado consistente que inclui 36 estudos, dos quais 28 foram randomizados e baseados em 2226 participantes (YAMMINE; VIOLATO, 2015 apud LÓPEZ; MIRANDA, 2018).

Por outro lado, em estudos realizados em países como o México, onde não há uma inserção precoce e organizada dos novos métodos tecnológicos em estágios educacionais, verifica-se uma gradativa resistência por parte dos aprendizes e dos docentes a respeito da substituição das metodologias tradicionais de ensino pelos novos modelos.

Em geral, a literatura acerca do processo de ensino-aprendizagem aponta que a preferência pelos métodos tradicionais de ensino não está relacionada à deficiência de recursos tecnológicos para complementar o ensino, mas sim a fatores como a disposição dos docentes em utilizá-los ou a falta de preparação para ensinar por meio dos novos recursos e a limitação dos alunos, tanto econômica quanto cognitivamente, a usá-los. Levis (2011), em seu artigo "Tecnologias Educacionais", apresenta como conclusão que o aluno se sente "confortável" em obter um método de ensino tradicional: em muitos casos, não está disposto a participar do uso da tecnologia se não for necessário, comportamento que, em geral, reflete a sua educação básica.

\section{Ambiente Computacional Utilizado no Ensino}

Existem diversas maneiras de utilizar as tecnologias disponíveis atualmente, mais especificamente o uso de computadores, tabletes, celulares, entre outros na sala de aula. Algumas questões que emergem aos docentes preocupados em adequar os métodos de trabalho e teorias de ensino aos avanços tecnológicos se expressam por: como escolher um ambiente computacional, uma categoria de software ou plataforma de ensino contendo um percurso formativo com textos, videoaulas em módulos, avaliações etc.? Quais fatores devem ser levados em conta e em qual momento na sala de aula?

Tomando como fundamentação teórico-prática as diversas abordagens de pesquisadores citados $\mathrm{e}$ refletindo sobre esses questionamentos tão complexos e importantes, esclarece-se que a escolha de um ambiente computacional merece reflexões e estudos mais aprofundados a esse respeito, de forma a vincular uma filosofia educacional, em que se acredita e se postula, a métodos e objetivos que se quer alcançar no desenvolvimento de assuntos relacionados a diferentes áreas do conhecimento.

Nesta perspectiva, buscam-se na literatura aspectos relacionados à escolha de ambientes computacionais que podem ser utilizados para a construção de um cidadão contemporâneo, participante e beneficente, com ferramentas de assimilação, interferência e participação realista (PAPERT, 1994). Estudos mostram a necessidade de adequação ao aperfeiçoamento da qualidade do ensino: diferentemente dos cursos de graduação em Medicina Humana, nas Ciências Agrárias e Biológicas por exemplo, metodologias alternativas que auxiliam no aprendizado do aluno são pouco existentes entre a comunidade acadêmica nas mais diferentes formas e condições (BRASIL, 2001; COSTA NETO \& MARTINS FILHO, 2017).

Assim, de todos os elementos básicos disponíveis no processo de ensino-aprendizagem nas mais diferentes áreas acadêmicas, o único que não se aplica a modelos alternativos mediados via sistema computacional é a formação de redes de aprendizagem que permitam a colaboração entre participantes (HOLMBERG, 2003; HARASIM, 2005).

A relação do aprendiz com o ensino via sistema computacional é defendida desde 1996 por Aretio (1996). O mesmo autor relata que, enquanto em aulas presenciais a relação docente-discente é mais 
íntima, com o ensino via sistema computacional é possível haver uma ligação com a organização e seus recursos estruturais, sendo fundamental um planejamento cuidadoso, com a implantação de uma estrutura adequada para atender à necessidade do aluno para que não se sinta isolado no processo, de forma a possibilitar cada vez mais a criatividade de transformação acadêmica curricular. Todavia, é necessário que os docentes responsáveis assumam o compromisso em identificar e selecionar ferramentas satisfatórias envolvidas em educação corporativa para o ensino superior (BARRY, 2016; MASSARI et al., 2018).

Desse modo, com a existência da famosa "geração conectada", o ensino on-line pode ser assistido e/ou ministrado por um sistema computacional que possibilita uma ampla simulação em alta resolução dos conteúdos. A partir disso, com os softwares é possível ter no âmbito educacional métodos interativos que envolvem a imersão dos estudantes nas habilidades e procedimentos psicomotores a serem praticados de forma sensorial, tridimensional e de interação com o conteúdo em tempo real e atualizado (MARTINSEN \& JUKES, 2005; THEORET et al., 2007).

Assim, com a introdução do ensino via sistema computacional, é notória uma rápida expansão, inclusão e sensação de conforto e de globalização da difusão do conhecimento empírico e científico. Foi a partir daí que surgiram novas possibilidades para que a população em massa tivesse acesso a novos conhecimentos e saberes multidisciplinares. O termo "Ensino a Distância" passa a ser mais utilizado a partir da década de 1980 , e o reconhecimento da sua utilização pode ser atestado quando, em 1982, o International Council for Correspondence Education (ICEE) decidiu mudar seu nome para Internacional Council for Distance Education (ICDE), fato este que revela a origem do termo EaD (HOLMBERG, 1995).

Utilizando a palavra-chave "Embryology" como consulta aos bancos de dados disponíveis via internet, segundo Ferreira et al. (2008), foi possível observar 977 mil ocorrências. Ao aprofundar a busca para o "conteúdo em português", o resultado cai para 445 mil ocorrências. Além disso, quando se trata da busca em "Embriologia Comparada", o número de ocorrências é reduzido para 75.200. Já ao navegar na busca de "Embriologia Comparativa", o resultado de ocorrências é igual a zero no que diz respeito a módulos de cursos em ambiente computacional, sendo que, em se tratando da Embriologia Comparada, as universidades não desfrutam de tal conteúdo.

Nos cursos presenciais existe uma barreira pertinente no ensino em aulas práticas, seja no estudo de embriões, órgãos ou em cadáveres de pequeno ou grande porte na Medicina Veterinária. Essa barreira é ocasionada pelo uso de formaldeído, paraformaldeído, tornando-se desconfortável o processo de ensino-aprendizagem, além de apresentar risco para a saúde tanto do docente quanto do discente e de funcionários no âmbito do laboratório, e de perpassar por possíveis fatores ambientes pela geração de resíduos químicos (MARTINSEN \& JUKES, 2005; THEORET et al., 2007; SIMÃO \& DE MELO, 2015).

Portanto, a busca de material e de métodos alternativos que tenha origem ética, alternativa $\mathrm{e}$ eficaz no ensino apresenta melhores soluções para a preservação, a conservação dos espécimes e maior cooperação entre os departamentos de interesse, a fim de se tornarem fontes essenciais no processo de ensino-aprendizagem para os dias atuais.

\section{Considerações Finais}

Ambientes computacionais e seus recursos constituem, portanto, um ambiente extremamente rico, de que docentes podem lançar mão para desenvolverem conteúdos relacionados com as diferentes áreas do conhecimento como, por exemplo, a embriologia comparativa. No entanto, a escolha de ambiente virtual vincula-se a diversos aspectos tanto teóricos, como metodológicos, porém um dos aspectos fundamentais consiste na mediação do professor. E o ambiente, por mais rico e construtivo que seja, por si só, não é suficiente para a promoção de contextos propícios para a construção do conhecimento. 
O processo de ensino-aprendizagem na contemporaneidade se constitui de novas demandas eloquentes nas mais diversas áreas do conhecimento, e aqui se destacam as Ciências Morfológicas. O surgimento dos métodos alternativos, inovadores e tecnológicos que auxiliam no ensino de forma efetiva, como as plataformas digitais, além das videoaulas que facilitam a aprendizagem e a visualização da complexidade dos processos envolvidos no desenvolvimento do animal, pode dar suporte extra a esse aprendizado.

De fato, esta revisão demonstra um novo campo de contribuição tanto na formação técnico-científica quanto cidadã, oferecendo aos aprendizes das áreas de interesse elementos facilitadores na abordagem acerca do seu estudo, com a perspectiva de minimizar o uso de animais em práticas de experimentação animal e usufruir dos recursos tecnológicos disponíveis, de forma a otimizar o tempo e o espaço do docente e do discente, sob uma ideia que possibilita a busca de novos caminhos, e a reavaliação constante de suas estratégias e objetivos.

Neste contexto, métodos alternativos de ensino se tornam impulsivos para a saída da inércia do método arcaico e tradicional do ensino em embriologia, estimulando a busca satisfatória pelo conhecimento de forma ativa, já que, como pensava Paulo Freire, a educação provoca no indivíduo a capacidade de transformar o mundo, envolvendo-se, cada vez mais, no processo de construção do conhecimento.

Desse modo, conclui-se que o uso de recursos extras no processo de ensino-aprendizagem se mostra essencial e eficaz para a aquisição de conhecimentos, mas que, dada sua complexidade, é necessária uma abordagem de forma multidisciplinar, a fim de que haja motivação para se promover uma formação mais efetiva do aprendizado.

\section{Referências Bibliográficas}

ARETIO, Garcia Lorenzo. La Educación a Distancia y La UNED. Madri: 1996.

BARRY, D. S. et al. "Anatomy education for the YouTube generation". Anatomical sciencies education, 152 v. 9 , n. 1,2016 , p. $90-96$.

BRASIL. (2001). Ministério da Educação. Plano Nacional de Educação. PNE/Ministério da Educação. Brasília, DF: Inep. Castro, M. H. M. (2001). Estado e mercado na regulasão da educasão superior. Recuperado de $<$ http://www.schwartzman. org.br/simon/desafios/8regulacao.pd†.

CARNEIRO-LEÃO, A. M. A.; SÁ, R. B. G. \& JOFFILI, Z. M. S. "Formação do Pensamento Científico no Ensino de Ciências: a Biologia e Suas Interfaces como Ponto de Reflexão". IV Colóquio Internacional Educaşão e Contemporaneidade, Laranjeiras, 2010.

CARNIATTO, I. A Formação do Sujeito Professor: Investigação Narrativa em Ciências/Biologia. Cascavel: Edunioeste, 2002.

COSTA NETO, J. M. \& MARTINS FILHO, E. F. "Substituição de Animais no Ensino: até que Ponto?". Revista CFMV, Brasília-DF, ano XXIII, $\mathrm{n}^{\mathrm{o}}$ 72, 2017, pp. 34-42.

DUMM, C. G. Embriología Humana: Atlas e Texto. Buenos Aires: El Ateneo, 2006.

FERREIRA, A. S. S. B. S. Elaboração e avaliação de um ambiente virtual para o ensinolaprendizagem de Embriologia. Tese, UNESP Botucatu, 2011, p. 90

GILBERT, S. F. "The Morphogenesis of Evolutionary Developmental Biology". International Journal of Developmental Biology, n. 47, 2003, pp. 467-477.

GUimarÃES, M. V.; FREIRE, J. E. C. \& MENEZES, L. M. B. "Utilização de Animais em Pesquisas: Breve Revisão da Legislação no Brasil". Rev. Bioét. (Impr.), vol. 24, n. 2, 2016, pp. 217-24 .

GUMMERY, E.; COBB, K. A.; MOSSOP, L. H. \& COBB, M. A. "Student Perceptions of Veterinary Anatomy Practical Classes: A Longitudinal Study". Journal of Veterinary Medical Education, 2017.

GHOSH, S. K. "Cadaveric Dissection as an Educational Tool for Anatomical Sciences in the 21st Century". Anatomical sciences education, vol. 10, n. 3, 2017, pp. 286-299.

HALL, B. K. Evolutionary Developmental Biology. London; New York: Chapman e Hall Suffolk. 1992, p. 275. 
HARASIM, L., TELLES, L., TUROFF, M. \& HILTZ, S. Redes de Aprendizagem - Um Guia para Ensino e Aprendizagem On-Line. São Paulo: Ed. Senac, 2005.

HOLMBERG, B. "A Theory of Distance Education Based on Empathy". In: MOORE, M. \& ANDERSON, William. Handbook of Distance Education, Mahwah, New Jersey, Lawrence Erlbaum Associates, 2003.

HOLMBERG, B. Theory and Practice of Distance Education. London: Routledge, 1995.

HYTTEL, P.; SINOWATZ, F. \& VEJSTED, M. Domestic Animal Embryology. 11th ed. Saunders, Elsevier, 2010, p. 359.

JOTTA, L. Embriologia Animal: uma Análise dos Liuros Didáticos de Biologia do Ensino Médio. 2005. 244 f. Dissertação (Mestrado em Educação), Faculdade de Educação da Universidade de Brasília, Brasília, 2005.

LEVIS, D. "Redes Educativas 2.1 - Médios Sociales, Entornos Colaborativos y Procesos de Enseñanza y Aprendizaje". Revista de Universidad del Conociemiento (RUSC), vol. 8, n. 1, 2011, pp. 7-24. Disponível em: 〈http://rusc.uoc.es.edu/ojs/ index.php/rusc/article/view/vbn1-levis/v8n1-levis >. Acessado em 10 ago. 2019.

MARTINSEN, Siri \& JUKES, Nick. "Towards a Humane Veterinary Education". Journal of Veterinary Medical Education, vol. 32, n. 4, 2005, pp. 454-460.

MASSARI, C. H. A. L.; SCHOENAU, L. S. F.; CERETA, A. D. \& MiglinO, M. A. "Tendências do Ensino de Anatomia Animal na Graduação de Medicina Veterinária”. Rev. Grad. USP, vol. 3, n. 2, jul. 2018.

McGUSKEY, Robert S.; CARMICHAEL, Stephen W.\& KIRGH,Darrell G. "TheImportance of Anatomy in Health Professions Education and the Shortage of Qualified Educators". Academic Medicine, vol. 80, n. 4, 2005.

MELLO, J. M. "Análise das Condições Didático Pedagógicas do Ensino de Embriologia Humana no Ensino Fundamental e Médio". Arquivos do MUDI, vol. 13, n. 1, 2009, pp. 34-45. MELO, P. A.; MELO, M. B., \& NUNES, R. S.
"Educação a Distância como Política de Expansão e Interiorização da Educação Superior no Brasil". Revista de Ciências da Administração, vol. 11, n. 24, 2009, pp. 278-301.

MONTIEL, J. M.; AFFONSO, S. A. B.; RODRIGUES, S. J. \& QUINELATO, E. "Escala de Percepção Discente do Ensino a Distância: Estudo de Validade". Avaliação Psicológica, vol. 13, n. 3, 2014, pp. 359-369.

MOORE, K. \& PERSAUD, T. V.N. Embriologia Básica. 8 ed. São Paulo: Elsevier, 2008, p. 462.

MOUL, R. A. T. M.; NUNES, F. G.; SILVA, R. N. M. \& LEÃO, A. M. A. G. "EnsinoAprendizagem de Embriologia sob a luz dos Paradigmas da Ciência: uma Análise sobre as Argumentações de Estudantes do Ensino Médio". XI Encontro Nacional de Pesquisa em Educação em Ciências - XI ENPEC, Universidade Federal de Santa Catarina, Florianópolis, SC, 3 a 6 de julho de 2017.

PAPERT, S. A Máquina das Crianças: Repensando a Escola Na era da Informática. Tradução de Sandra Costa. Porto Alegre: Artes Médicas, 1994.

SIMÃO, V.T.G.\&MELO, M.I. V. de. "Inovação Tecnológica no Ensino da Anatomia Veterinária". Sinapse Múltipla, vol. 4, n. 1, 2015, p. 63.

SLACK, J. M. W.; HOLLAND, P. W. H. \& GRAHAM, G. F. "The Zootype and the Phylotypic Stage". Nature, vol. 361, 1993, pp. 490-492.

RICHARDSON, M. K.; GOBES, S. M. H.; VAN LEEUWEN, A. C.; POLMAN, A. E.; PIEAU, G. \& SANCHEZ-VILLAGRA, M. "Heterochrony in Limb Evolution: Developmental Mechanisms and Natural Selection". Journal of Experimental Zoology (Mol. Dev Evol), vol. 312B, 1999, pp. 1-26.

THEORET, C. L.; CARMEL, É. N. \& BERNIER, S. "Why Dissection Videos Should Not Replace Cadaver Prosections in the Gross Veterinary Anatomy Curriculum: Results from a Comparative Study". Journal of Veterinary Medical Education, vol. 34, n. 2, 2007, pp. 151-156.

WILSON, A. B.; MILLER, C. H.; KLEIN, B. A.; TAYLOR, M. A.; GOODWIN, M.; BOYLE, 
Métodos Alternativos no Processo de Ensino-Aprendizagem em Embriologia Comparativa

E. K.; BROWN, K.; HOPPE, C. \& LAZARUS, M. "A Meta-Analysis of Anatomy Laboratory Pedagogies". Clinical Anatomy, vol. 31, 2017, pp. 122-133.

YAMMINE, Kaissar; VIOLATO, Claudio. "A meta-analysis of the educational effectiveness of three-dimensional visualization technologies in teaching anatomy". Anatomical sciences education, v. 8 , n. 6, 2015, pp. 525-538.

ZERBINI, T., \& ABBAD, G. "Estratégias de Aprendizagem em Curso a Distância: Validação de uma Escala". Psico-USF, vol. 13, n. 2, pp. 177187, 2008.

Publicado em 28/07/2020. 


\section{APÊNDICE G - Pesquisa de satisfação}

$18 / 11 / 2020$

PESQUISA de SATISFAÇÃO

\section{PESQUISA de SATISFAÇÃO}

Olá!

Este questionário tem como objetivo avaliar o quanto você ficou satisfeito ou não ao ter participado do projeto intitulado Plataforma digital: método alternativo de ensino-aprendizagem da embriologia comparativa com foco no sistema cardiovascular.

*Obrigatório

1. NOME COMPLETO *

2. E-MAIL *

3. IDADE *

Marcar apenas uma oval.
Até 20 anos
21-30 anos
31-40 anos
41-50 anos
51-60 anos
Acima de 60 anos

4. $\mathrm{CPF}$ * 


\section{TERMO DE CONSENTIMENTO LIVRE E ESCLARECIDO *}

Você está sendo convidado(a) como voluntário(a) a participar da pesquisa Plataforma digital: método alternativo de ensino-aprendizagem da embriologia comparativa com foco no sistema cardiovascular. A justificativa, os objetivos e os procedimentos: 0 motivo que nos leva a estudar a implantação da plataforma, uma plataforma educacional de Embriologia Comparativa é, ao final desta experiência, investigar a aquisição de conhecimentos científico pelos estudantes dos cursos de Ciências Biológicas, Medicina Veterinária e afins. A pesquisa se justifica pela necessidade de contribuir para a educação, aprimorando o uso de métodos alternativos no processo de ensino-aprendizagem da embriologia. 0 objetivo desse projeto é investigar o impacto da implantação da plataforma virtual sobre os alunos. Os procedimentos de coleta de dados ocorrerão da seguinte forma: três questionários serão disponibilizados individualmente aos estudantes para serem respondidos, sendo uma enquete inicial, uma avaliação final e uma pesquisa de satisfação. Desconfortos e riscos e benefícios: Não existe qualquer desconforto ou risco mínimo para que você se submeta à coleta de dados quais serão analisados exclusivamente pelo pesquisador (docente responsável). Tal coleta justifica-se pela necessidade de avaliar o que os estudantes aprenderam por meio do método virtual de ensino, para que, em conjunto, possamos melhorar sua aplicação no futuro discutindo seus alcances e suas limitações. Garantia de esclarecimento, liberdade de recusa e garantia de sigilo: Você será esclarecido(a) sobre a pesquisa em qualquer aspecto que desejar. Você é livre para recusar em participar, retirar seu consentimento ou interromper a participação a qualquer momento. A sua participação é voluntária e a recusa em participar não irá acarretar qualquer penalidade ou perda de benefícios. 0 pesquisador irá tratar a sua identidade com padrões profissionais de sigilo. Os resultados dos questionários serão enviados para você e permanecerão confidenciais. Seu nome ou o material que indique a sua participação não será liberado sem a sua permissão. Você não será identificado(a) em nenhuma publicação que possa resultar deste estudo. Uma cópia deste consentimento informado será arquivada com o pesquisador e outra será fornecida a você. Custos da participação, ressarcimento e indenização por eventuais danos: A participação no estudo não acarretará custos para você, bem como não será disponível nenhuma compensação financeira adicional. Afirmo que fui informada (o) dos objetivos da pesquisa acima de maneira clara e detalhada e esclareci minhas dúvidas. Sei que em qualquer momento poderei solicitar novas informações e motivar minha decisão se assim o desejar. Contudo, autorizo a publicação das minhas respostas tanto na tese do doutorando Marcos Paulo Batista de Assunção quanto em artigos científicos que vierem a ser publicados.

Marcar apenas uma oval.

CONCORDO com o termo acima

NÃO CONCORDO com o termo acima

6. INSTRUTOR/PROFESSOR * 


\section{NIVVEL DE ESFORÇO}

Marcar apenas uma oval por linha.

Fraco Moderado Satisfatório
$\begin{aligned} & \text { Seu nível de dedicação ao } \\ & \text { curso }\end{aligned}$

8. NIVELL DE APRENDIZADO

Marcar apenas uma oval por linha.

Nível de
habilidade/conhecimento no
início do módulo

Nível de

habilidade/conhecimento no fim

do módulo

Nível de

habilidade/conhecimento

exigido para concluir o módulo

Contribuição do módulo para

habilidade/conhecimento 


\section{HABILIDADE E RECEPTIVIDADE DO INSTRUTOR}

Marcar apenas uma oval por linha.

$\begin{array}{cccc}\text { Discordo } & \text { Discordo Não sei Concordo } & \begin{array}{c}\text { Concordo } \\ \text { totalmente }\end{array}\end{array}$

0 instrutor foi um

palestrante/demonstrador

eficiente

As apresentações foram
claras e organizadas
instrutor estimulou o
interesse dos alunos
instrutor usou bem o durante as aulas
instrutostativo foi acessível $\mathrm{e}$

10. CONTEÚDO DO MÓDULO I

Marcar apenas uma oval por linha.

Discordo
totalmente
os conjetivos foram claros
planejado do curso foi

A carga horária do curso

foi apropriada

O curso foi organizado

para permitir a

participação de todos os

alunos matriculados 
11. QUAIS ASPECTOS DESTA PLATAFORMA FORAM MAIS ÚTEIS OU VALIOSOS?

12. COMO VOCÊ MELHORARIA O MÓDULO, BEM COMO OS CONTEÚDOS DISPONIVEIS PARA ACESSO?

13. MARQUE UMA DAS OPÇÕES ABAIXO QUE MELHOR CORRESPONDE AO TIPO DE FERRAMENTA QUE VOCÊ MAIS UTILIZA PARA ESTUDAR EMBRIOLOGIA, ALÉM DAS AULAS TRADICIONAIS NA UNIVERSIDADE.

Marcar apenas uma oval.
Discussões com os colegas de classe.
Livros didáticos e artigos científicos publicados em periódicos.
Monitoria presencial nos laboratórios da universidade.
Sites de busca como o Google e videoaulas no YouTube.
Anotações de slides apresentados nas aulas. 
14. DE 1 A 5 QUANTO VOCÊ ACREDITA QUE APRENDER OS CONCEITOS E A ORIGEM DAS PALAVRAS, OU SEJA, A ETIMOLOGIA DOS TERMOS EMBRIOLÓGICOS TE AJUDOU ESTUDAR EMBRIOLOGIA?

Marcar apenas uma oval.

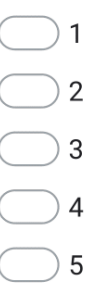

15. VOCÊ ACREDITA QUE AS TRANSPOSIÇÕES DIDÁTICAS CRIADAS A PARTIR DO ADOBE PHOTOSHOP EM ALTO RELEVO PODEM TE AUXILIAR NO PROCESSO DE ENSINO-APRENDIZAGEM ACERCA DO DESENVOLVIMENTO EMBRIONÁRIO?

Marcar apenas uma oval.

Sim, é um complemento às peças orgânicas.

Sim, é um método alternativo em alto grau de detalhes ultra estrutural.

Não, em nada ajudaria eu estudar por imagens virtuais.

16. A PLATAFORMA APRESENTADA COMO MÉTODO ALTERNATIVO DE ENSINO MOSTROU-SE CLAREZA E DE FÁCIL MANIPULAÇÃO?

Marcar apenas uma oval.

$\operatorname{Sim}$

Não, pulei alguns conteúdos. 
17. VOCÊ ENFRENTOU ALGUM PROBLEMA TÉCNICO RELATIVO A PLATAFORMA QUE TE IMPOSSIBILITOU ALGUMA VEZ DE ACESSÁ-LA?

Marcar apenas uma oval.

$\operatorname{Sim}$

Não

18. COMO FOI SUA ADAPTAÇÃO AO ENSINO EM AMBIENTE VIRTUAL?

19. QUANTO VOCÊ ACREDITA QUE A PLATAFORMA VIRTUAL PODE COMPENSAR, EM PARTES, O TEMPO "PERDIDO" DE ACESSO AO CONTEÚDO NA SALA DE AULA DITA COMO TRADICIONAL?

Marcar apenas uma oval.

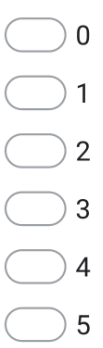


20. QUAL FOI A SUA MOTIVAÇÃO PARA ACESSAR A PLATAFORMA?

Marcar apenas uma oval.

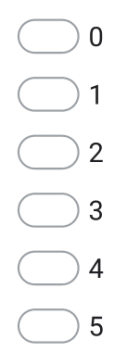

21. QUAL O SEU GRAU DE SATISFAÇÃO EM PARTICIPAR COMO VOLUNTÁRIO DESTE PROJETO?

Marcar apenas uma oval.

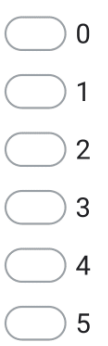


22. DO MATERIAL PEDAGÓGICO DISPONIVEL NA PLATAFORMA, O QUANTO ELES TE AUXILIARAM A COMPREENDER OS PROCESSOS ENVOLVIDOS NO DESENVOLVIMENTO DO ANIMAL?

Marcar apenas uma oval.

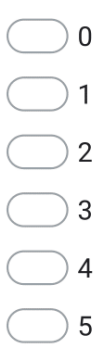

23. QUAL FOI O TEMPO DE INTERRUPÇÃO APÓS INICIAR SEUS ESTUDOS POR MEIO DA PLATAFORMA?

Marcar apenas uma oval.

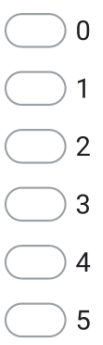


24. O QUANTO COMPAROU OS CONTEÚDOS DISPONIBILIZADOS NA PLATAFORMA COM OUTROS RECURSOS OU MATERIAIS?

Marcar apenas uma oval.

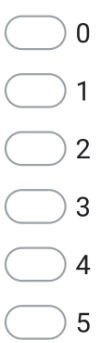

25. QUAL O SEU TEMPO DE UTILIZAÇÃO DA INTERNET PARA ESTUDOS?

Marcar apenas uma oval.

$\Longrightarrow$ Cerca de 40 min a 1 hora

De 2 a 3 horas

De 4 a 5 horas

Mais de 5 horas

26. DE O A 5 QUAL NOTA VOCÊ APLICA PARA A PLATAFORMA "EMBRIOLOGIA COMPARATIVA" HOSPEDADA NA EAD GURU?

Marcar apenas uma oval.

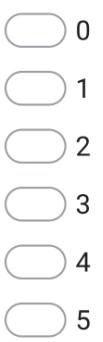


27. DEIXE AQUI SEU DEPOIMENTO, CRÍTICAS E/OU SUGESTÕES A RESPEITO DESTA PLATAFORMA DE ENSINO.

Este conteúdo não foi criado nem aprovado pelo Google.

Google Formulários 
ANEXO 


\section{ANEXO A - Termo de doação dos ovos fertilizados}
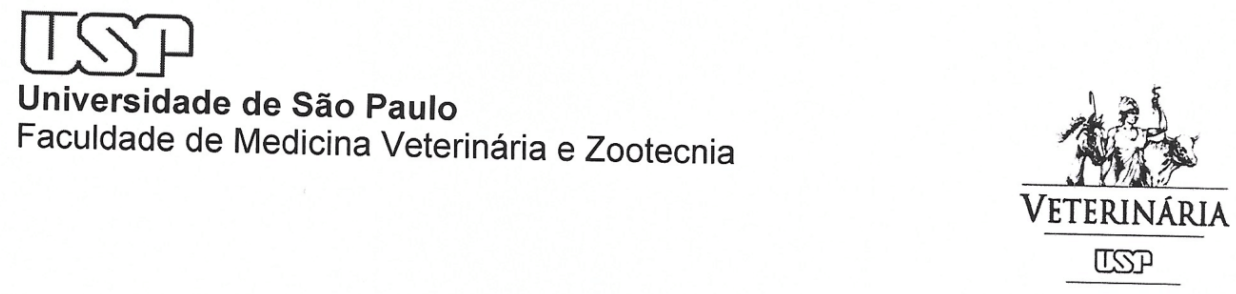

São Paulo, 12 de setembro de 2019.

\section{TERMO DE DOAÇÃO}

Declaramos para os devidos fins que o Laboratório de Ornitopatologia, Departamento de Patologia, FMVZ - USP doou para o pós-graduando de doutorado Marcos Paulo Batista de Assunção e para a Profa. Dra. Maria Angélica Miglino, pertencentes ao programa de pós-graduação em Anatomia dos Animais Domésticos e Silvestres, Departamento de Cirurgia - FMVZ-USP, 63 ovos embrionados de galinha (Gallus gallus domesticus) de um a 21 dias de idade para compor a "Plataforma digital: método complementar de ensino-aprendizagem da embriologia comparativa com foco no sistema cardiovascular", aprovado pela CEUA FMVZ-USP, protocolo n. ${ }^{\circ} 6988100818$.

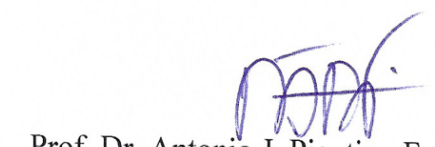

Prof. Dr. Antonio J. Piantino Ferreira

Responsável pelo laboratório de Ornitopatologia

FMVZ-USPM 